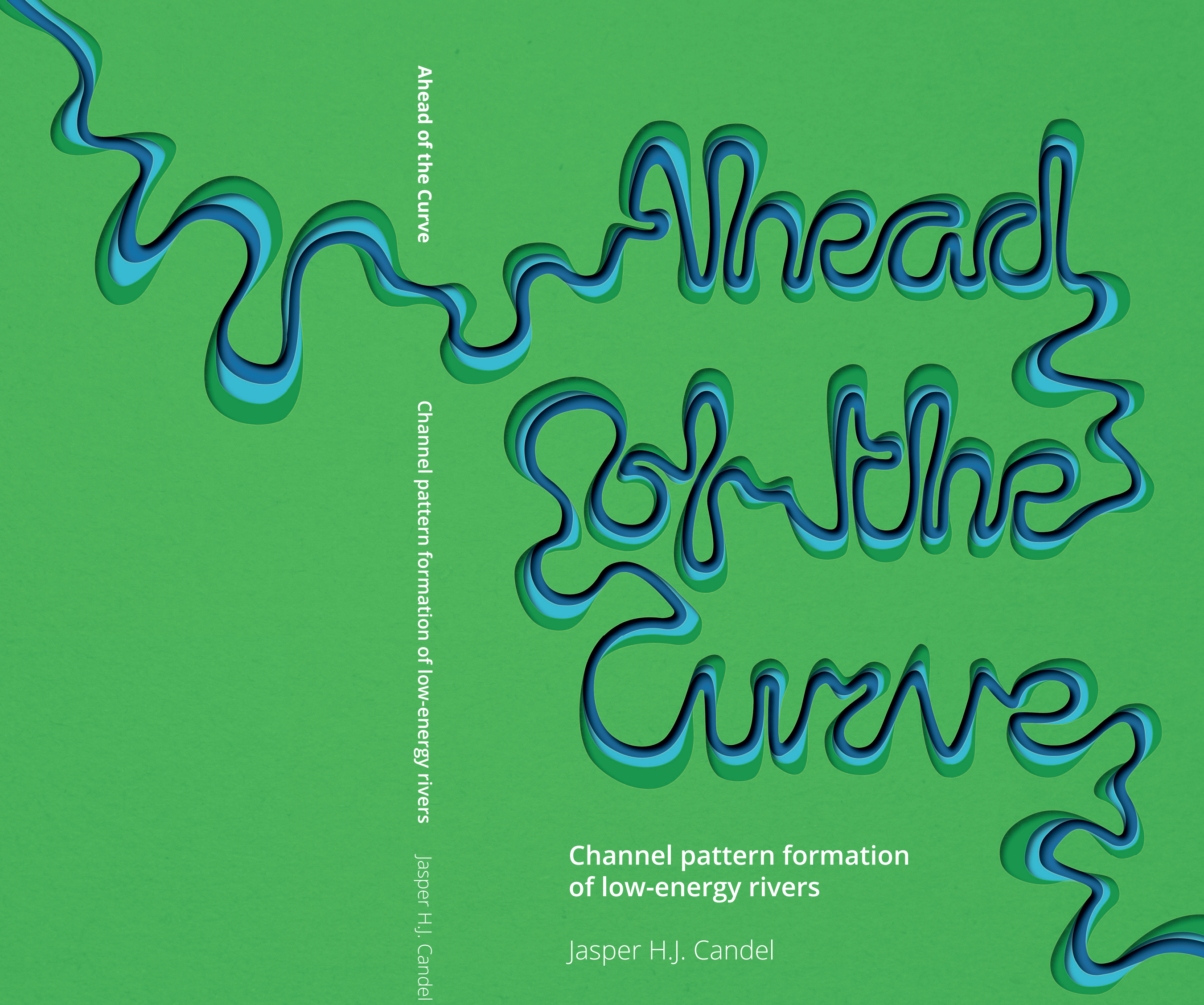




\section{Propositions}

1. Re-meandering of low-energy rivers hardly leads to meandering. (this thesis)

2. Channel pattern and lateral mobility of low-energy rivers is determined by subsurface rather than hydrological characteristics.

(this thesis)

3. Dikes are dead-end roads in delta management.

4. Geomorphological processes are too often ignored when defining ecological targets.

5. Universities achieve most societal impact through education.

6. Tenure track assessment criteria based on quantitative performance indicators harm scientific excellence.

7. Students of Environmental Sciences must know the feeling, sight, smell, taste and sound of their study sites.

Propositions belonging to the thesis of Jasper Candel

'Ahead of the curve - Channel pattern formation of low-energy rivers'

Wageningen, 18 February 2020 


\section{Ahead of the curve}

\section{Channel pattern formation of low-energy rivers}

Jasper H.J. Candel 


\section{Thesis committee}

\section{Promotors}

Prof. Dr J. Wallinga

Professor of Soil Geography and Landscape

Wageningen University \& Research

Prof. Dr M.G. Kleinhans

Professor of Physical Geography

Utrecht University

\section{Co-promotor}

Dr A. Makaske

Lecturer, Soil Geography and Landscape Group

Wageningen University \& Research

\section{Other members}

Prof. Dr D. Kleijn, Wageningen University \& Research

Prof. Dr J. Croke, University College Dublin, Ireland

Prof. Dr G. Verstraeten, KU Leuven, Belgium

Dr E. Mosselman, Deltares, Delft

This research was conducted under the auspices of the C.T. de Wit Graduate School of

Production Ecology \& Resource Conservation (PE\&RC) 


\title{
Ahead of the curve
}

\section{Channel pattern formation of low-energy rivers}

\author{
Jasper H.J. Candel
}

\section{Thesis}

submitted in fulfilment of the requirements for the degree of doctor

at Wageningen University

by the authority of the Rector Magnificus,

Prof. Dr A.P.J. Mol,

in the presence of the

Thesis Committee appointed by the Academic Board

to be defended in public

on Tuesday 18 February 2020

at 4 p.m. in the Aula. 
Jasper. H.J. Candel

Ahead of the curve - Channel pattern formation of low-energy rivers 264 pages.

$\mathrm{PhD}$ thesis, Wageningen University, Wageningen, The Netherlands (2020)

With references, with summary in English and Dutch

ISBN 978-94-6395-210-1

DOI https://doi.org/10.18174/506616 
Alleen de koekoek in de verte

Is het bewijs van dit moment

Hier en nu wordt lang geleden

Muffig en vertrouwd

In de diepte daar beneden

Rachel Schipper 


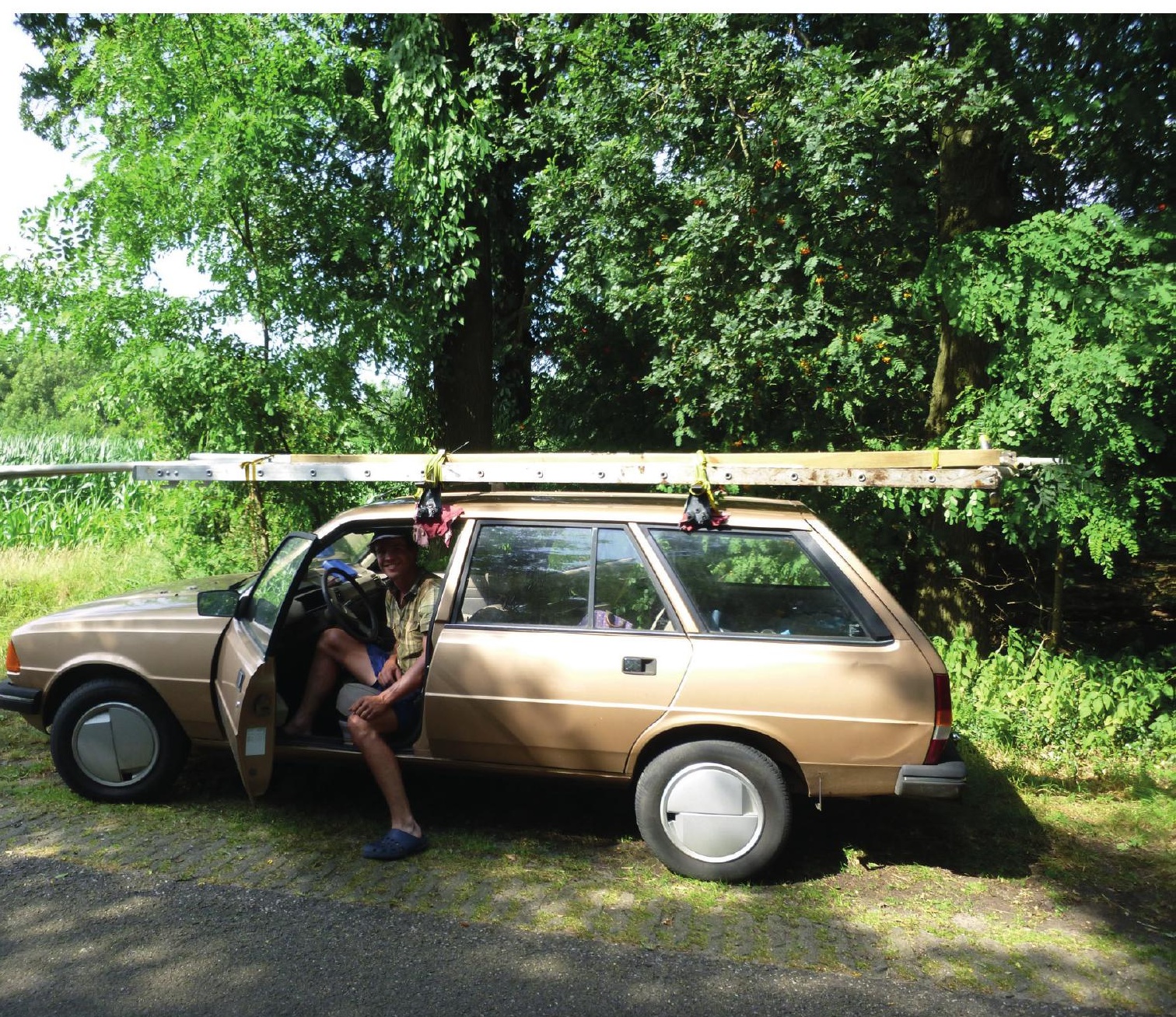


'Hier moeten we zijn,'zegt Jasper. Zoals gewoonlijk rijdt hij zijn oude Pengeot 305 iets te ver de berm en struiken in. Hij is lang niet altijd zuinig op zijn spullen.

We zijn op zoek naar een beek. Een bovenloop van de Drentsche Aa. Op een vrij willekeurige plek in het weiland naar mijn idee. Maar vandaag ben ik met een bodemkundige op pad en dan krijg je er een paar ogen bij. Drenthe lijkt nog steeds zo plat als een dubbeltje, maar van Jasper leer ik al snel dat dit een kwestie van perspectief is. Nadat we onder het prikkeldraad zijn doorgekropen en onder het toeziend oog van een stier en koeien het weiland oversteken, blijk ik eigenlijk over een acht meter diep dal te wandelen, dat de afgelopen duizenden jaren met veen is opgevuld.

De bodem onder dat veen bestaat uit 'oud dekzand' dat tijdens de laatste ijstijd (zo'n tienduizend jaar geleden) van de drooggelegde Noordzee hiernaartoe is gewaaid. De komende dagen zouden we het dankzij onze boringen regelmatig tegenkomen. Net als een vijfduizend jaar oude hazelnoot trouwens, en diep in de grond bewaarde stukken elsen-en eikenhout. Restanten van een lang vergeten bos.

Vanwege het hoge gras wordt het beekje onderweg pas zichtbaar. Trouwens, als ik de beek tijdens een normale wandeling wel van afstand zou hebben gezien, dan zou ik er slechts half bewust aandacht aan hebben besteed. Ik zou al snel mijn blik verder laten dwalen over het gras, langs de dorre, kreupele boom, en naar het bos in de verte, waarvan de kleuren zachtjes meedeinen op de warmte. Na een paar seconden zou ik mijn pas hebben hervat.

Maar nu blijven we hier. Uren. Met toewijding doe ik dan ook wat er te doen valt: ik versleep apparatuur, doe grondboringen, haal veen en zand naar boven, help bij de zoektocht naar een verklaring voor het gekronkel van de beek. Soms vraag ik me af of de bomen waarvan we slechts de restanten naar boven halen ooit door andere mensen zijn aangeraakt; en of er na komende ijstijden nog mensen zullen zijn die zich over restanten van onze tijd verbazen.

Terwijl mijn gedachten af en toe afdwalen, maken onze bezigheden me steeds meer vertrouwd met deze plek. Al doende krijg ik er toegang toe: over elk hobbeltje binnen een straal van tien meter ben ik meerdere keren heen gewandeld. In slakkentempo en met een radar op wielen achter me aan, die metingen doet in de grond. Ik herken inmiddels de minimale glooiing van het land die volgens Jasper op diepere, onzichtbare dalen wijst. En ik weet waar de brandnetels langs de oever staan; hoe hard het water stroomt; waar de beek smal genoeg is om er zonder narigheid overheen te springen; welke routes door het gras de snelste zijn; hoe fijn de schaduw is van de twee bomen verderop. 
En toch: hoe meer deze plek tot me gaat spreken, des te merkwaardiger zij wordt.

Jasper tuurt nu al een tijdje op het scherm dat hij op zijn borst draagt. Hij probeert een of ander raadsel op te lossen. Ik hoor de wind zo zachtjes ruizen dat de stilte voelbaar wordt, als een soort onhoorbare, maar alles doordringende achtergrondmuziek. Al tienduizend jaar loopt hier een beekje. Meters lager dan war we ons nu bevinden, maar toch liep het hier ergens. En doordat het langzaam, uiterst langzaam door het veen en de tijd omhoog werd geduwd staan wij nu hier. Naast de oude, kreupele boom in de zon.

Vreemde plek dus, deze vrij willekeurige hoek in het weiland.

En dan boren we nog maar acht meter diep. Hoeveel verder zou je niet nog kunnen boren, de aarde en de tijd in? Hoeveel meer betekenissen liggen er in het gras verborgen, waarvoor je misschien weer heel andere ogen, radars en bezigheden nodig hebt?

Deze beek in het veen, die brandnetels aan de oever, die paar bomen met hun schaduw - al deze dingen vormen de oppervlakte van een diepte die zich voortdurend verborgen houdt, ook al brengen we af en toe iets aan het licht. Zoals ze daar nu in stilte stromen en staan: eenmalige momenten in het immense, zich telkens opnieuw ontvouwende raadsel tijd.

Bas Nabers 


\section{Acknowledgments}

Studying the environment by becoming part of it, that is how I would describe the first years of my PhD. Together with a lot of help of others, I performed more than 300 corings, which are ca. $1.2 \mathrm{~km}$ in length if you add them all up. This was doing paid fitness in combination with science! I have eaten so much peat that my teeth turned black and the acid removed the enamel of my teeth. I have smelt the inorganic conditions of the swampy spots in the river valleys. I have emptied my full boots at least twenty times, because I stepped in the wrong spot. I have been dancing around while coring, because that would hopefully keep away the mosquitos. I have saved several students from sinking in the peat (and so did they save me many times) or swimming in ditches that, in retrospect, were slightly to wide to jump over. I have felt how erosion-resistant peat and clay can be, by trying to force the auger into the soil. I have heard the silence of some last pieces of Dutch nature. I have seen beautiful tortuous river patterns that made my mind blow. This dissertation is the product of this exciting ride, and I would like to thank many people that have contributed to this journey, or supported me on the way as my friends and family.

First of all I want to thank my supervisors. I am extremely grateful for the supervision by Bart, Jakob and Maarten. I could not have thought of a better team than this team with these different personalities! Bart, I very much appreciated to have you as daily supervisor. You went through an enormous amount of text to provide it from feedback over the last five years, which was always done in the highest precision thanks to your keen eye for detail. Your knowledge of the field was a very valuable source for nice discussions, and thanks to you I have learnt a lot about fluvial sedimentology. Besides the $\mathrm{PhD}$, we have been teaching a lot of students together. You gave me the space to develop my teaching, and I am very much looking forward to the next years to take thousands of students together to places such as Doldersum or Berkenwoude to show the beautiful link between geomorphology, soils and land use. Jakob, I was very happy to have you both as a supervisor and the big boss of the group. You really helped raising the bar of my $\mathrm{PhD}$, and thanks to you we almost got in Nature (almost!). You really helped structuring manuscripts, and challenged me to make a strong link between science and practice. Besides the content, you created a very pleasant atmosphere, had a lot of trust, and gave me a lot of space to explore other collaborations or scientific approaches. I am very much looking forward to work together in the future, and it is largely because of you that SGL is a great place to work. Maarten, sometimes I thought I was part of a movie when I was standing with this crazy professor in an office for 5 hours, writing complex formulas on all whiteboards and windows of the office, eating white raspberry Tony's Chocolonely with crackles. Diving into the matter and fundaments together was 
one of the best parts of my $\mathrm{PhD}$, and I am very thankful that you shared so much of your knowledge with me. You have inspired me with your enthusiasm for teaching and science. The best of all are your out of office replies, which deserve a tile.

Secondly, I would like to thank my colleagues of SGL, RiverCare, other universities and people that I collaborated with. Marijn and Selçuk, many thanks for the "jolly good fun" in the office and after work. Great to have you as my friends at and after work! Also thanks to all other PhDs of SGL with who I shared a large part of the time of my $\mathrm{PhD}$ with, for creating a very nice atmosphere: Simona, Chantal, Maricke, Luc, Cindy, Marcos, Kasia, Tijn. Specific thanks to my colleagues Alice and Erna for your patience in the OSL lab. I am not that talented in working with tiny, miniscule discs and sand grains as you know, so discs flying around was the rule rather than the exception. Many thanks to my colleagues that have inspired me to continue teaching: Roel Dijksma and Gert Peek. I am very happy that you were my teachers, supervisors and colleagues during my MSc or PhD. Your inspiring way of teaching is what forms the actual impact of the university, and I am very happy that I get the chance to be part of this impact. Many thanks to Mieke for arranging so much in the group. Vans that disappear or touring cars that are too small for the amount of students, thanks to you problems are always solved. Anneke, thanks for cleaning the SGL offices and corridor, and sorry for the big mess that I tend to make. Many thanks to all other SGL colleagues for the nice moments during the coffee breaks or SGL BBQs, and for all kinds of different scientific or educational collaborations. I am very happy to continue working with you all! Also thanks to Joep Storms and Wim Hoek for collaborating together during my PhD. I would like to thank all students that I have supervised during their BSc, MSc or internship: Eric, Gijs, Ellen, Maartje, Renathe, Niels, Claudia, Menno, Meike, Erwin, Tom, Eline, Monique and Gibran. Specific thanks to Niels, with whom I spent most time of everyone in the field. You were unstoppable and never stopped coring. I am extremely happy with your help, and it was great to visit all these places driving around on dirt roads in my old Peugeot. Thanks to all colleagues of RiverCare for the discussions on the RiverCare days and social activities. Especially thanks to Tjitske with whom I collaborated a lot during the start of my PhD. Together we visited many waterboards in The Netherlands, and had great discussions on the small rivers that we studied. I want to thank all members of the user committee that represented their organizations: STOWA, NWO, Rijkswaterstaat, Witteveen \& Bos, WENR and all waterboards: De Dommel, Rijn en IJssel, Limburg, Vallei en Veluwe, Vechtstromen, Drents Overijsselse Delta, Hunze en Aa. I believe that our project was a big success, thanks to the meetings and collaborations we had together. 
Thirdly, I want to thank all my friends with whom I spent a lot of time on skies somewhere in a remote place where your food freezes before you finish it, on the road or MTB bike, in the canoe or sailing boat, on the squash or tennis court, making a "small campfire”, or on a chair enjoying a beer: Gabriël, Rense, Pim, Stefan, Bas, Martijn, Fedor, Laura, Victor, Jesse, Chris. Gabriël and Rense, we know each other already for a long time since we are students, I love your craziness and I am happy that you will be my paranymphs during my defense (hope you can sit still for at least 1 hour). Also thanks to my study friends (the BWA Boys) of which some are also member of the legendary soil-drilling competition team Moffel \& Piertje: Anne-Kees, Adriaan, Hans, Stefan, Christian, Tobias, Piet, Thijs, and all other clowns and smurfs. Thanks to all people of Haarweg 71 where I spent my entire study time and the first year of my PhD. Too many people have lived there to name all of you, but the memories of these years are still great.

Tot slot, wil ik mijn familie bedanken. Lieve pap en mam, heel erg bedankt voor jullie onvoorwaardelijke liefde, steun en interesse. De basis die jullie voor mij gelegd hebben is zeer waardevol, en daar heb ik het grootste deel van dit werk aan te danken. Bedankt voor de vrijheid die jullie mij gegeven hebben om te gaan doen waar m'n passie ligt. Bart en Jeroen, over een goede basis gesproken, ik vind het geweldig hoe wij als broers nog steeds zo close zijn, en heel veel samen doen en kunnen bespreken. Super dat dankzij jullie ook Laura en Oana onderdeel zijn van de Candel-familie, een geweldige aanvulling! Opa en oma, ik ben erg dankbaar voor jullie grote interesse in mij, en geweldig dat we nog steeds zo'n goed contact hebben. Esther, Job en Meike, ontzettend bedankt voor hoe jullie mij opgenomen hebben in de Schippers familie en me de "wel ja!" mentaliteit hebben aangeleerd, oftewel, alles is te maken of te fixen. Een mooie instelling! Tot slot, lieve Rachel, wat ben jij een topvrouw! Ik zou niet weten hoe ik dit werk zonder jou had kunnen schrijven. Je eindeloze geduld, je luisterend oor (gelukkig heb je er twee) en alle feedback op zowel inhoud als proces van mijn $\mathrm{PhD}$ die je hebt gegeven, daar ben ik je oneindig dankbaar voor. Daarnaast ben ik zo blij dat je altijd vrolijk bent, van aanpakken houdt, en samen met mij veel onderneemt. Ik ben ontzettend gelukkig met onze kleine Wout, die ik ook wil bedanken voor het mij succesvol laten afronden van mijn PhD tijdens zijn eerste weken op deze aardbol. 



\section{Table of contents}

Acknowledgments

Chapter 1 Introduction

$\begin{array}{ll}1.1 \text { River restoration } & 21\end{array}$

$\begin{array}{ll}1.2 \text { Low-energy rivers } & 23\end{array}$

$\begin{array}{ll}\text { 1.2.1 Definition and focus } & 23\end{array}$

1.2.2 Channel pattern and floodplain classification 24

1.2.3 Channel pattern formation $\quad 25$

1.2.4 Channel pattern prediction $\quad 26$

$\begin{array}{ll}1.3 \text { Research objectives } & 27\end{array}$

$\begin{array}{ll}1.4 \text { Approach and organization } & 27\end{array}$

$\begin{array}{ll}\text { 1.4.1 Timescale of study } & 27\end{array}$

$\begin{array}{ll}\text { 1.4.2 Study sites and thesis outline } & 28\end{array}$

Chapter 2 Oblique aggradation: a novel explanation for sinuosity of lowenergy streams in peat-filled valley systems 35

$\begin{array}{ll}2.1 \text { Introduction } & 37\end{array}$

2.2 Study Area $\quad 39$

2.3 Methodology $\quad 42$

2.3.1 Lithological description $\quad 42$

2.3.2 GPR $\quad 42$

2.3.3 OSL dating $\quad 43$

2.3.4 ${ }^{14} \mathrm{C}$ dating $\quad 44$

2.3.5 Inferences on lithogenesis $\quad 45$

2.4 Results $\quad 51$

2.4.1 Lithogenetic units $\quad 51$

2.4.2 Cross-sections $\quad 54$

2.5 Conceptual model 56

2.5.1 Stream evolution as a function of valley shape 56

2.5.2 Effects on stream planform $\quad 59$

2.6 Discussion $\quad 61$

2.6.1 Landscape evolution in low-energy streams 61

2.6.2 Lessons for stream restoration $\quad 64$

2.7 Conclusions $\quad 65$ 


\section{Chapter 3 Self-constraining of low-energy meandering rivers; a novel}

explanation for tortuous planforms and low mobility

3.1 Introduction 69

3.2 Materials and Methods $\quad 71$

$\begin{array}{ll}3.2 .1 \text { Study area } & 71\end{array}$

3.2.2 Ground-penetrating radar $\quad 74$

3.2.3 Coring and Lithology $\quad 74$

3.2.4 OSL Dating $\quad 76$

3.2.5 ${ }^{14} \mathrm{C}$ Dating $\quad 77$

3.2.6 Comparison to other meandering rivers $\quad 77$

3.3 Results $\quad 80$

3.3.1 Lithogenetic units $\quad 80$

$\begin{array}{ll}\text { 3.3.2 Cross-sections } & 87\end{array}$

3.3.3 Spatial configuration $\quad 89$

3.3.4 Morphodynamics 90

3.4 Conceptual model 90

3.4.1 Concepts of self-constraining low-energy meandering rivers 90

3.4.2 Applicability to other low-energy meandering rivers 94

3.5 Discussion 96

3.5.1 Prerequisites $\quad 96$

3.5.2 Implications 97

3.6 Conclusions 98

Chapter 4 Late Holocene channel pattern change from laterally stable to meandering - a palaeohydrological reconstruction 101

4.1 1ntroduction 103

$\begin{array}{ll}4.2 \text { Study area } & 107\end{array}$

4.3 Methods 108

4.3.1 Lithological description 108

4.3.2 Ground-penetrating radar 109

4.3.3 Grain size analysis $\quad 109$

$\begin{array}{ll}\text { 4.3.4 OSL dating } & 109\end{array}$

4.3.5 ${ }^{14} \mathrm{C}$ dating $\quad 110$

4.3.6 Channel dimensions $\quad 110$

$\begin{array}{ll}\text { 4.3.7 Palaeodischarge } & 112\end{array}$

4.3.8 Sediment transport $\quad 113$

4.3.9 Potential specific stream power $\quad 114$

4.3.10 Bar regime $\quad 114$

4.3.11 Errors and uncertainty $\quad 116$ 
4.4. Results 116

4.4.1 Lithogenetic units 116

4.4.2 Dating results 120

4.4.3 Meander and channel geometry 122

4.4.4 Palaeohydrology 123

4.5. Discussion 128

4.5.1 Laterally stable phase $\quad 128$

4.5.2 Channel pattern change $\quad 129$

4.5.3 Meandering phase 131

4.6 Conclusions 132

Chapter 5 Predicting river channel pattern based on stream power, bed material and bank strength $\quad 135$

5.1 1ntroduction 137

5.1.1 River channel patterns 137

5.1.2 Channel pattern discriminators $\quad 138$

5.1.3 Controlling parameters of channel pattern $\quad 139$

5.1.4 Research aim 141

5.2 Comparison of channel pattern discriminators and their discriminative power 141

5.2.1 River dataset and channel pattern characterization $\quad 141$

5.2.2 Empirical channel pattern discriminators $\quad 143$

5.2.3 Physics-based channel pattern discriminators $\quad 145$

5.2.4 Evaluation and comparison of discriminators as predictors 148

5.3 Including bank strength in the empirical channel pattern prediction 151

5.3.1 Empirical relations between stream power and bank strength 151

5.3.2 New channel pattern predictor $\quad 154$

5.4 Discussion 158

5.5 Conclusions 162 
$\begin{array}{lll}\text { Chapter } 6 & \text { Synthesis and conclusions } & 165\end{array}$

6.1 Introduction 167

6.2 Typology of low-energy rivers 167

6.2.1 River types 167

6.2.2 Channel and floodplain morphology 168

6.3 Channel pattern formation $\quad 171$

6.4 Key forming factors $\quad 174$

6.4.1 Stream power $\quad 174$

6.4.2 Bank strength 179

6.4.3 Bar regime $\quad 181$

6.4.4 Concluding remark 181

6.5 Extrapolation of results outside the studied scales 182

6.5.1 Temporal scale $\quad 182$

6.5.2 Discharge scale $\quad 184$

6.5.3 Grain size scale $\quad 185$

6.6 Implications $\quad 185$

6.6.1 River restoration: river management $\quad 185$

6.6.2 River restoration: ecology 188

6.7 Conclusions 190

6.8 Future research 191

$\begin{array}{ll}\text { Summary } & 197\end{array}$

$\begin{array}{ll}\text { Samenvatting } & 203\end{array}$

$\begin{array}{ll}\text { Appendices } & 209\end{array}$

$\begin{array}{ll}\text { References } & 227\end{array}$

$\begin{array}{ll}\text { Curriculum Vitae } & 259\end{array}$ 




\title{
Chapter 1
}

\author{
Introduction
}





\subsection{River restoration}

Over the past centuries, rivers in many parts of the world have been channelized and straightened to enhance navigation, to drain the land, to reduce bank erosion and to produce hydropower (Brookes et al., 1983; Gibling, 2018; Best, 2019). In recent decades, it was realized that river channelization has considerable drawbacks: it affects the ecology by loss of ecological niches, lowers the groundwater tables increasing the vulnerability to droughts, and results in high discharge peaks that increase the risk of flooding (Brookes, 1988; Verdonschot and Nijboer, 2002; Didderen et al., 2009; Graf et al., 2016; Candel et al., 2017). Water managers have drastically changed their views on management of river systems during the last decades, following the Water Framework Directive (WFD) in Europe, and the Endangered Species Act (ESA) and Clean Water Act (CWA) in the United States. Restoration of rivers has become an important theme aiming to restore the natural ecological functions and river morphodynamics (Soar and Thorne, 2001; Gumiero et al., 2013; Petts, 2018). However, river restoration often fails, because scientific knowledge is insufficiently incorporated (Wohl et al., 2005) and ecological improvement is limited (Pedersen et al., 2014; Hering et al., 2015; Verdonschot et al., 2015), though the actual success of river restoration is difficult to determine, because river restoration practices are often implemented without having set clear goals or states of success (McMillan and Vidon, 2014).

An important measure currently used to restore the ecology in many small rivers is remeandering (see Figure 1.1) (Lorenz et al., 2009), in which the river's "natural" state is restored (Newson and Large, 2006) often by mimicking the sinuous pattern from before channelization (e.g. from historical maps) (Kondolf, 2006). However, it has been argued that reference states should not be used in river restoration projects, because historic river conditions may not be valid anymore and previous states may be impossible to return to (Dufour and Piégay, 2009). Moreover, the ecological state of rivers does often not improve when the natural geomorphological conditions are ignored in re-meandering projects (Pedersen et al., 2014). Therefore, it has been argued that we should learn from the processes that shaped the historic river morphology and focus on restoring those processes in current river restoration practices (Kondolf, 2006; Brierley and Fryirs, 2009; Pedersen et al., 2014; Brierley and Fryirs, 2015). 
This thesis contributes to the research program RiverCare, supported by the Netherlands Organization for Scientific Research (NWO). This research program aims to enhance the knowledge for managing low-energy river systems in a more effective way, making optimum use of natural processes to reduce maintenance costs and create self-sustaining rivers (Hulscher et al., 2014). In this research program, the Rhine and Meuse in The Netherlands form the main case study rivers, representing rivers in a delta and lowland setting. In this thesis, the focus is on relatively small low-energy rivers (further specified in Sect. 1.2.1), and particularly on re-meandering of these rivers in the context of river restoration.
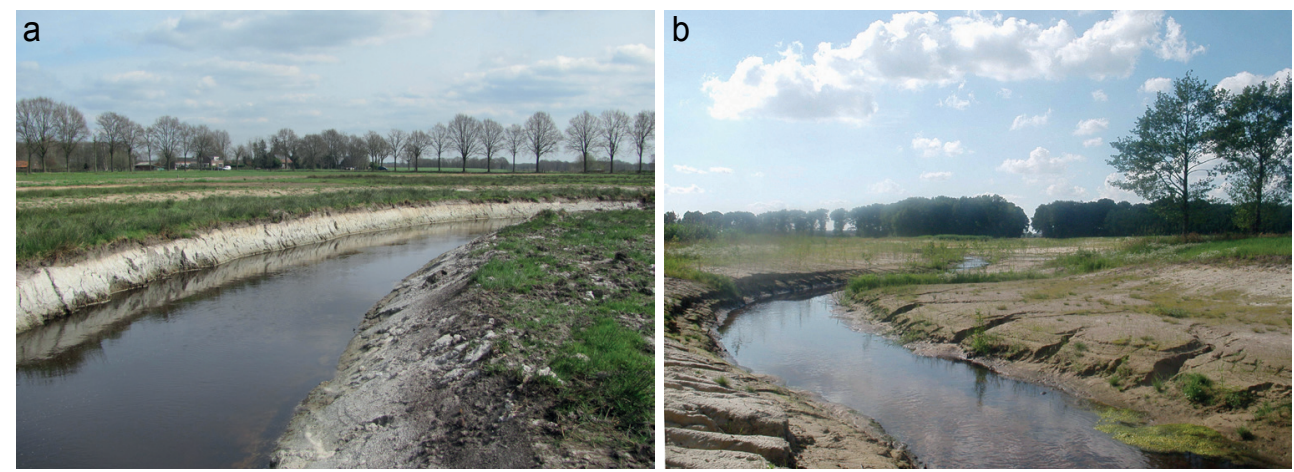

Figure 1.1 Examples of re-meandered small, low-energy rivers, a) the Vierlingse Beek, with steep clay banks on both sides, b) the Leuvenumse Beek, with sand banks on both sides. The gullies on the river bank formed by intense rainfall.

Realization has grown that geomorphological expertise is needed to help planning river restoration (Pasternack, 2013), to give insight into future channel pattern, dynamics and space needed for the river to freely erode its banks without threatening infrastructure (Makaske and Maas, 2015; Dépret et al., 2017), and to align the ecological state to the geomorphological conditions (Pedersen et al., 2014). Most low-energy rivers, both natural and restored, are often classified as immobile or non-dynamic (Kleinhans and Van den Berg, 2011; Eekhout, 2014). Many small natural rivers lack the geomorphological features, such as scroll bars or neck cut-offs, that testify to active lateral migration (e.g. see Figure 1.2 and Sect. 1.2.2) (Kleinhans and Van den Berg, 2011; Makaske et al., 2016), and hardly showed lateral displacement over recent decades to centuries, as shown by historical map analyses (e.g. Kuenen, 1944; Woodyer et al., 1979; Hooke and Yorke, 2010; Eekhout et al., 2013; Dépret et al., 2017). For the small re-meandered rivers, Eekhout and Hoitink (2015) showed that most morphological changes, e.g. cutoffs, occurred right after construction of the new channel, because restored channel banks were unstable due to lack of vegetation (Corenblit et al., 2015; Van Oorschot et al., 2016; Vargas-Luna et al., 2018). Once vegetation fixed the river banks, few 
morphological adjustments were observed and restored low-energy rivers were more or less laterally stable (Eekhout et al., 2014).

These observations raise questions about how laterally active restored low-energy rivers will be in the long term, and what spatial demands such restored systems have. Predictions on these issues require fundamental understanding of how natural lowenergy rivers develop sinuous patterns.

\subsection{Low-energy rivers}

\subsubsection{Definition and focus}

In this thesis, the focus is on low-energy rivers, which are referred to as those having a specific stream power lower than $10 \mathrm{~W} \mathrm{~m}^{-2}$, based on a recent classification scheme by Gurnell et al. (2014) that builds further on the classification scheme by Nanson and Croke (1992). The focus is on small low-energy rivers to which the restoration measure of re-meandering mostly applies; rivers with a bankfull discharge $<200 \mathrm{~m}^{3} \mathrm{~s}^{-1}$. This type of low-energy rivers is abundantly present on the northwestern European lowland plain (Verdonschot and Van den Hoorn, 2010; Eekhout, 2014).

Low-energy rivers can be divided into alluvial and non-alluvial rivers. Alluvial rivers are defined by the self-formed bed and banks, built from fluvially transported sediments that are influenced by the river's flooding rate and magnitude (Nanson and Croke, 1992). Non-alluvial rivers are, for example, bedrock rivers (Finnegan and Dietrich, 2011), which are laterally constrained and are not able to build a floodplain. Lowenergy, alluvial rivers can further be subdivided into multi-channel (i.e. anastomosing) rivers and single-channel rivers, which commonly accommodate single-thread channels instead of multi-thread (i.e. braiding) channels (Nanson and Croke, 1992; Makaske, 2001; Kleinhans and Van den Berg, 2011). In this thesis, the focus is on the channel pattern (i.e. planform) formation of single-channel, single-thread, alluvial rivers that are located in a valley setting, in which the valley side forms the floodplain boundary.

Low-energy, alluvial rivers commonly have clastic floodplains built of fluvially transported sediments (Nanson and Croke, 1992). Nanson (2009) argued that rivers with organic floodplains built from peat should also be considered as alluvial rivers, because the height of the floodplain is determined by the flow regime of the present channel. Organic floodplains are therefore considered as alluvial rivers, and included in this research. 


\subsubsection{Channel pattern and floodplain classification}

River patterns of single-channel, single-thread alluvial rivers can be classified based on different morphological characteristics. Leopold and Wolman (1957) and Rust (1978) distinguished between two types based on sinuosity (distance along the channel divided by the straight line distance): meandering rivers when sinuosity is higher than 1.5 , and straight rivers when sinuosity is lower than 1.5 . True straight rivers may occur as part of anastomosing rivers (Makaske, 2001), but are quite rare as single-channel rivers (see example in Figure 1.2b) (Leopold and Wolman, 1957; Kleinhans and Van den Berg, 2011). Rosgen (1994) expanded this classification by distinguishing rivers based on sinuosity, entrenchment, gradient, and width-depth ratio of the channel. The advantage of such approaches is that channel pattern classes are quantitatively, and thus objectively, distinguished.

However, sinuosity is not suitable to use in a channel pattern classification of singlechannel rivers if one seeks to distinguish different classes of morphodynamics (Simon et al., 2007). Kleinhans and Van den Berg (2011) showed for a large river dataset that river sinuosity did not correlate with stream power, and that laterally active rivers do not necessarily show higher sinuosity than laterally stable rivers. Both laterally stable and meandering rivers may display sinuous patterns, but the responsible geomorphic processes are different (Figure 1.2).
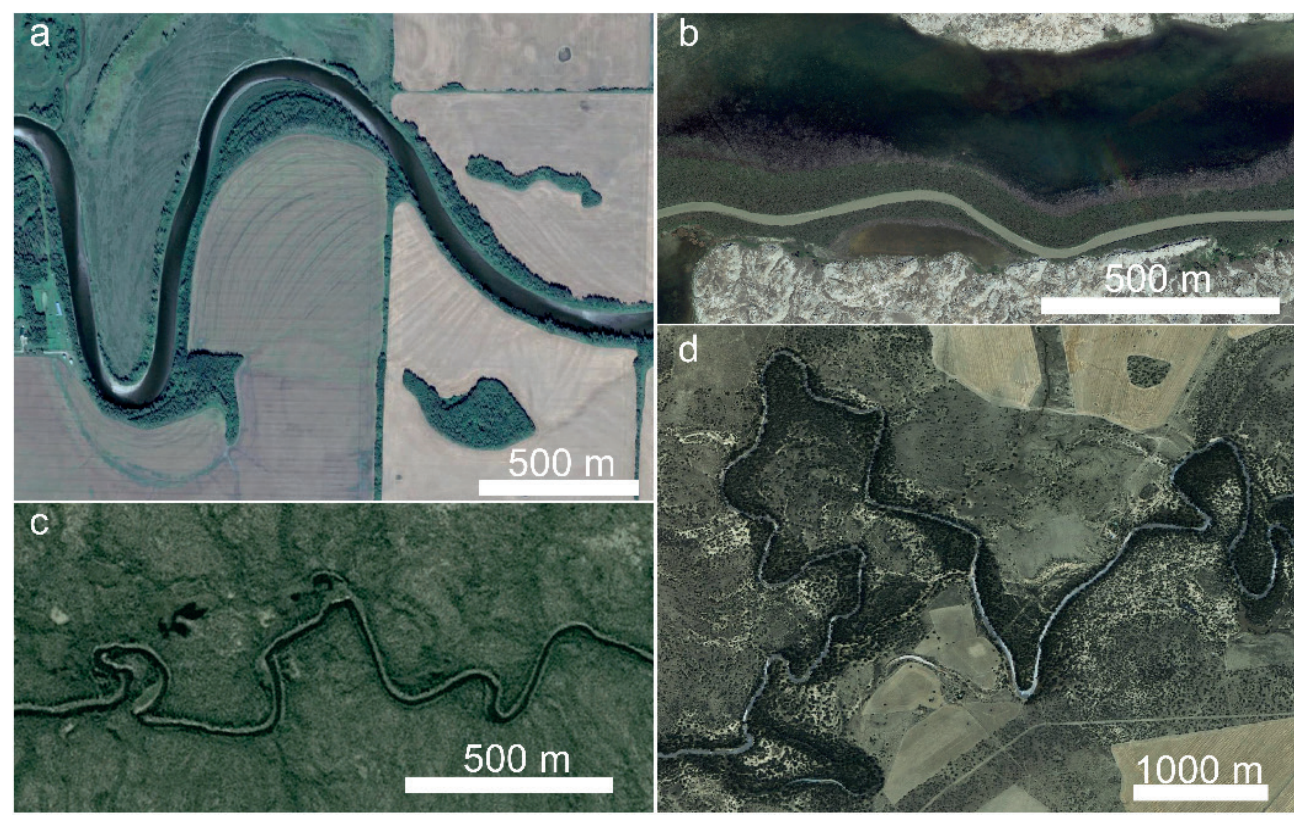

Figure 1.2 Different channel patterns of low-energy rivers, a) the meandering Pembina River with scroll bars in Canada, b) the relatively straight Milk River in the USA, c) an unnamed, irregular sinuous peatland river in Canada, and d) the laterally stable, irregular sinuous Barwon River in Australia (Kleinhans and Van den Berg, 2011). 
Single-channel, sinuous patterns are often considered to result from a meandering river style: erosion of the outer bank, and deposition on the inner bend, caused by interaction between the flow and bed leading to instability, amplified by bend flow (Struiksma et al., 1985; Ikeda and Parker, 1989; Nanson and Knighton, 1996; Seminara, 2006; Kleinhans and Van den Berg, 2011). Meandering results in a scrolled floodplain (Figure $1.2 \mathrm{a}$ ), which consists of consecutive levees on the inner bank of river bends (Mason and Mohrig, 2019). These scroll bars are absent when rivers are laterally stable. The floodplain morphology thus reflects the river morphodynamics. Therefore, Nanson and Croke (1992) and Kleinhans and Van den Berg (2011) suggested to classify singlechannel river types based on the presence (Figure 1.2a) or absence (Figure 1.2b-d) of these morphological features in the river channel and floodplain, to distinguish meandering rivers from laterally stable rivers.

The floodplain also forms an important control on the channel pattern of single-channel rivers (Nanson and Croke, 1992; Kleinhans, 2010; Kleinhans et al., 2018). In their floodplain classification, Nanson and Croke (1992) distinguished floodplains of lowenergy rivers from medium- and high-energy river types partly based on the relatively high floodplain cohesivity of low-energy rivers. They suggested that lateral stability results from the inability to erode banks due to the low stream power compared to the erosion-resistance of the cohesive floodplain.

\subsubsection{Channel pattern formation}

Although laterally stable rivers are distinguished from meandering rivers within some channel pattern classifications (Nanson and Croke, 1992; Makaske, 2001; Kleinhans and Van den Berg, 2011), it is still poorly understood how laterally stable rivers form their sinuous patterns. Laterally stable rivers may show occasional bend migration when bends are located in an easily erodible part of the floodplain (Nanson and Croke, 1992; Bogoni et al., 2017). Bends may also form as a result of random and local perturbations. For example, tree fall may result in flow diversion and hence the formation of bends (Gurnell et al., 2002; Geertsema et al., in review). Seepage can weaken river banks and lead to local bend formation (Van Balen et al., 2008; Eekhout et al., 2013). Trampling and grazing of cows (Trimble and Mendel, 1995) or elk (Beschta and Ripple, 2006; Beschta and Ripple, 2012) have been shown to widen river channels. These random and local perturbations may explain bend formation and hence the formation of a sinuous pattern, but do not imply systematic active meandering processes, in which meander trains develop (i.e. sequences of laterally migrating meander bends) (Seminara, 2006). Sinuous channel patterns of laterally stable rivers may also be inherited from former fluvial style. For example, if bedrock rivers have a sinuous pattern, this can be a relic of a former alluvial meandering style followed by strong incision (Barbour, 2008). Non-alluvial channels on the intertidal 
mudflat are sinuous, predominantly because the initial conditions determine the path of least resistance (Kleinhans et al., 2009). Brown and Keough (1992) showed that laterally stable, alluvial rivers in the United Kingdom inherited their pattern from a former river style reflecting higher discharge. Also the partial abandonment of former meandering river valleys may result in inheritance of the sinuous channel pattern by underfit, laterally stable rivers, such as the former Rhine branches in the Niers and Oude IJssel valley (Kasse et al., 2005; Janssens et al., 2012).

Notebaert and Verstraeten (2010) and Brown et al. (2018) suggested that many singlechannel, low-energy rivers in European lowlands were dispersed wetland systems or swampy meadows during the Early and Middle Holocene, lacking a clearly defined channel or consisting of very small channels in a multi-channel network. Single-channel river patterns formed during the Late Holocene as a result of land cover change (mainly deforestation) and historical water engineering, and clastic floodplains formed on top of former peaty floodplains (Walter and Merritts, 2008; Notebaert and Verstraeten, 2010; Broothaerts et al., 2014a; Brown et al., 2018). In northwestern Europe, these river changes occurred approximately since the Roman period, when human influence on the landscape started to become prominent (Notebaert and Verstraeten, 2010; Pierik, 2017), while continents such as Northern-America and Australia experienced large river channel changes much later, after European settlement (Eyles, 1977a, b; Walter and Merritts, 2008). However, these studies do not explain how and why the single-channel pattern developed.

\subsubsection{Channel pattern prediction}

Many channel pattern discriminators have been proposed that describe under which initial conditions different channel patterns form (Leopold and Wolman, 1957; Van den Berg, 1995; Eaton et al., 2010; Kleinhans and Van den Berg, 2011). Discriminators were originally developed to describe the conditions of occurrence, but may also be used as a predictor if parameters are used that are independent of actual channel pattern (Van den Berg, 1995). Channel pattern predictors would benefit river restoration projects, because they provide insights into the expected lateral mobility and channel pattern of the restored river. However, hitherto, no channel pattern discriminator exists that successfully discriminates and predicts different types of low-energy rivers (Kleinhans and Van den Berg, 2011; Makaske et al., 2016). Additionally, current channel pattern discriminators tend to ignore the floodplain properties despite their large effect on channel pattern of low-energy rivers (Nanson and Croke, 1992; Eaton et al., 2010; Kleinhans and Van den Berg, 2011). These shortcomings hamper our capability of predicting channel patterns and lateral dynamics of low-energy rivers. Developing a channel pattern predictor requires fundamental understanding of how channel patterns of low-energy rivers evolve, and under what conditions the channel pattern may change to a different channel pattern. 


\subsection{Research objectives}

In this thesis, I focus on the channel pattern formation and lateral activity of low-energy rivers (defined in Sect. 1.2.1), to help the planning and design of proper morphological river restoration measures. The research objectives in this thesis are:

- To define a typology of low-energy rivers, accounting for their channel pattern, floodplain morphology and floodplain sediment composition.

- To reconstruct the channel pattern formation of different types of low-energy rivers and identify the key forming factors of channel pattern.

- To develop a channel pattern predictor for different types of low-energy rivers based on parameters independent of actual channel pattern.

\subsection{Approach and organization}

\subsubsection{Timescale of study}

In this thesis, I focus on the channel pattern formation of low-energy rivers during the Holocene. A sufficiently long time period is chosen to capture the relatively slow processes in low-energy rivers. Moreover, the climatological conditions during the Holocene were comparable with the current climatological conditions (Mayewski et al., 2004; Wanner et al., 2008). Human influence was absent to limited during the Early and Middle Holocene, hence the natural morphodynamics can be derived from this period, while the Late Holocene provides insights into human-induced processes (Brown et al., 2018).

In Figure 1.3 an overview is shown of different methodologies that can be used to study river morphodynamics (Grabowski et al., 2014). The most suitable method to study channel pattern formation of low-energy rivers during the Holocene is by palaeogeographic research. Other methods such as field monitoring, remote sensing and historical maps cover too short timescales to give sufficient insight into the relatively slow processes of channel pattern formation of low-energy rivers (e.g. Eekhout, 2014). Moreover, these methods only cover the period when human influence was high and most northwestern European rivers were already channelized and affected by discharge regulation. 


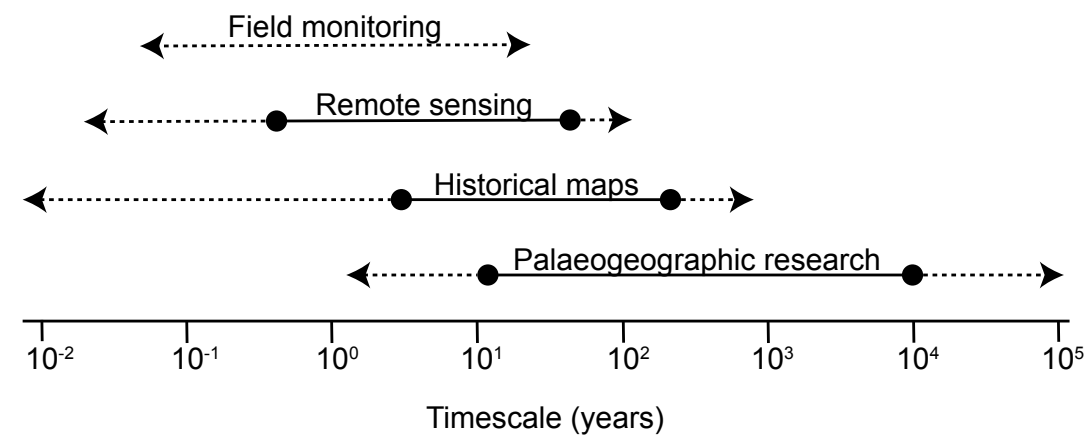

Figure 1.3 Temporal scales of different methodologies that can be applied to study river morphodynamics. Solid lines indicate the main temporal range, dashed lines indicate the potential range of the method (adapted from Grabowski et al., 2014).

\subsubsection{Study sites and thesis outline}

The thesis outline is shown in Figure 1.4. In this research, small low-energy rivers are studied in the Netherlands, where they are abundantly present in the part of the country without tidal influence (above sea level). The landscape in the eastern and southern Netherlands is part of the northwestern European lowland plain and is predominantly covered by Pleistocene coversands (Huijzer and Vandenberghe, 1998), and referred to as "glacial and periglacial sand landscape" in Figure 1.5 (Jongmans et al., 2012). Different geographical settings were selected in The Netherlands where channel pattern formation was studied in more detail (Figure 1.5, Chapters 2 to 4). I selected low-energy rivers with predominantly peaty (Ch. 2), heterogeneous (Ch. 3) and sandy valley fills (Ch. 4), respectively (Figures 1.4 to 1.6). Different valley fills were selected for the case studies, because the floodplain composition may have a large effect on the channel pattern formation, as outlined in Sect. 1.2. The case study rivers also differ in hydrological and morphological characteristics (Table 1.1). Their channel pattern was sufficiently wellpreserved to reconstruct its formation of each of these rivers from before regulation and/ or channelization.

All case studies were carried out to improve the general process understanding, rather than to explain the channel pattern evolution at the site. Hence, each case study river was compared to other rivers worldwide, where similar morphodynamic processes may have shaped the river channel pattern. Based on these insights, I developed a channel pattern predictor of low-energy rivers (Ch. 5, Figure 1.4). 


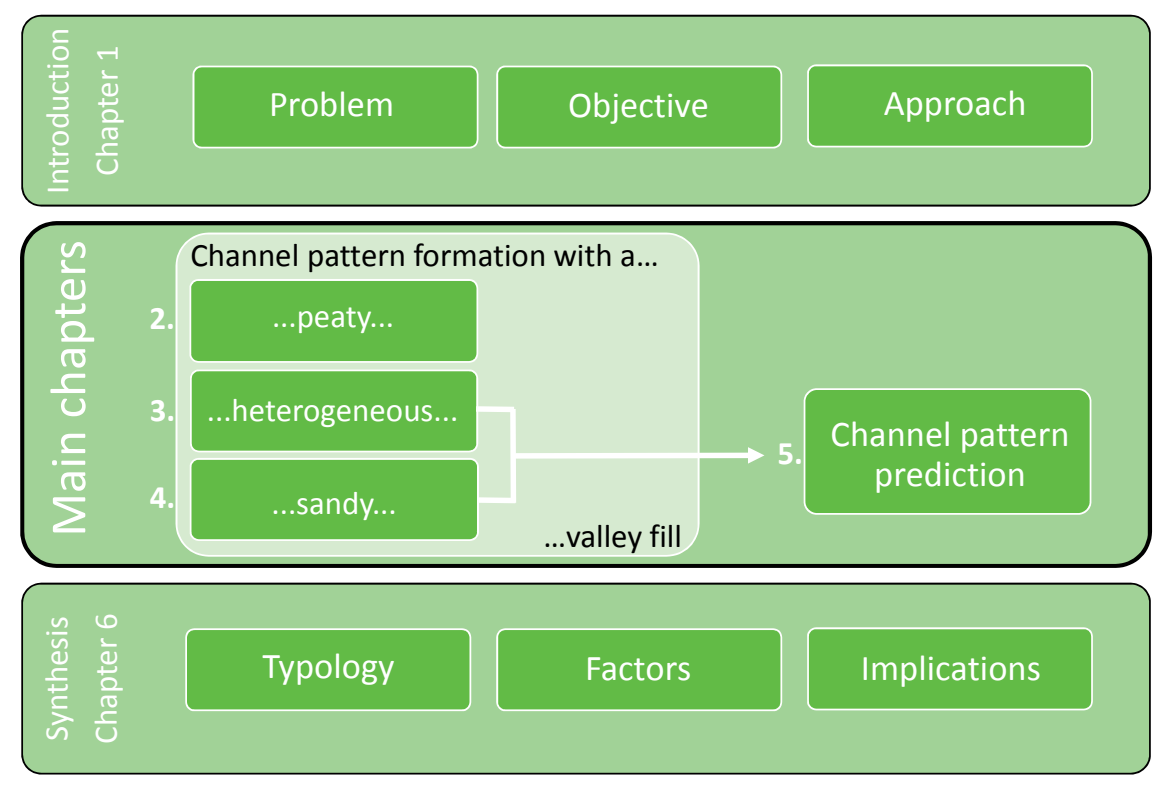

Figure 1.4 Visualization of the thesis outline.

In Chapter 2, I describe the channel pattern formation of low-energy rivers in peat-filled valleys. These rivers are referred to as streams, because they have a very low mean annual discharge (Table 1.1). The study area is located in the northern Netherlands (Figures 1.5 and 1.6a), where low-energy river valleys were predominantly filled with peat during most of the Holocene (Makaske et al., 2015). I describe the channel pattern of these streams, which has a typical bend shape. Based on a palaeogeographic reconstruction, I propose a novel concept on how these typical river bends form within a peat-filled valley.

In Chapter 3, I describe the channel pattern formation of low-energy sand-bed rivers in a predominantly clastic valley setting with a heterogeneous valley fill. The study area is located in the southern Netherlands (Figures 1.5 and 1.6b), where low-energy rivers within such valley settings are abundantly present (Bisschops, 1973). Based on a palaeogeographic reconstruction, a conceptual model is presented on how river bends form in these settings, which is elaborated using river data from around the world.

In Chapter 4, I describe the channel pattern formation of low-energy sand-bed rivers in a predominantly clastic valley setting with a predominantly sandy valley fill. I describe how low-energy rivers may change their pattern from laterally stable to actively meandering based on a case study in the eastern Netherlands (Figures 1.5 and 1.6c). This river changed from laterally stable to meandering in the Late Holocene and caused excessive, but isolated meander bends (Quik and Wallinga, 2018). The causes of the 


\section{Chapter I}

channel pattern change are elaborated in this chapter, by reconstructing the change of morphology in conjunction with the change of discharge with time.

In Chapter 5, I present a channel pattern predictor for rivers with a clastic valley fill, based on the insights gained from chapters 3 and 4 (Figure 1.4). In order to develop this predictor, existing empirical and physics-based channel pattern discriminators were reviewed, and the most successful in terms of prediction was determined. The new predictor includes an additional channel pattern class based on Chapter 3, and an additional parameter describing bank strength. The channel pattern predictor is available as an online tool that can be used by river managers and the research community.

The main chapters are either published peer-reviewed papers (Chapters 2 and 4) or have been submitted to be published (Chapters 3 and 5). To reflect on the objectives, I synthesize these chapters in the final Chapter 6 , in which I elaborate upon the typology of low-energy rivers, the key forming factors determining channel pattern of low-energy rivers, and the implications for river restoration and future research (Figure 1.4). 


\section{General introduction}

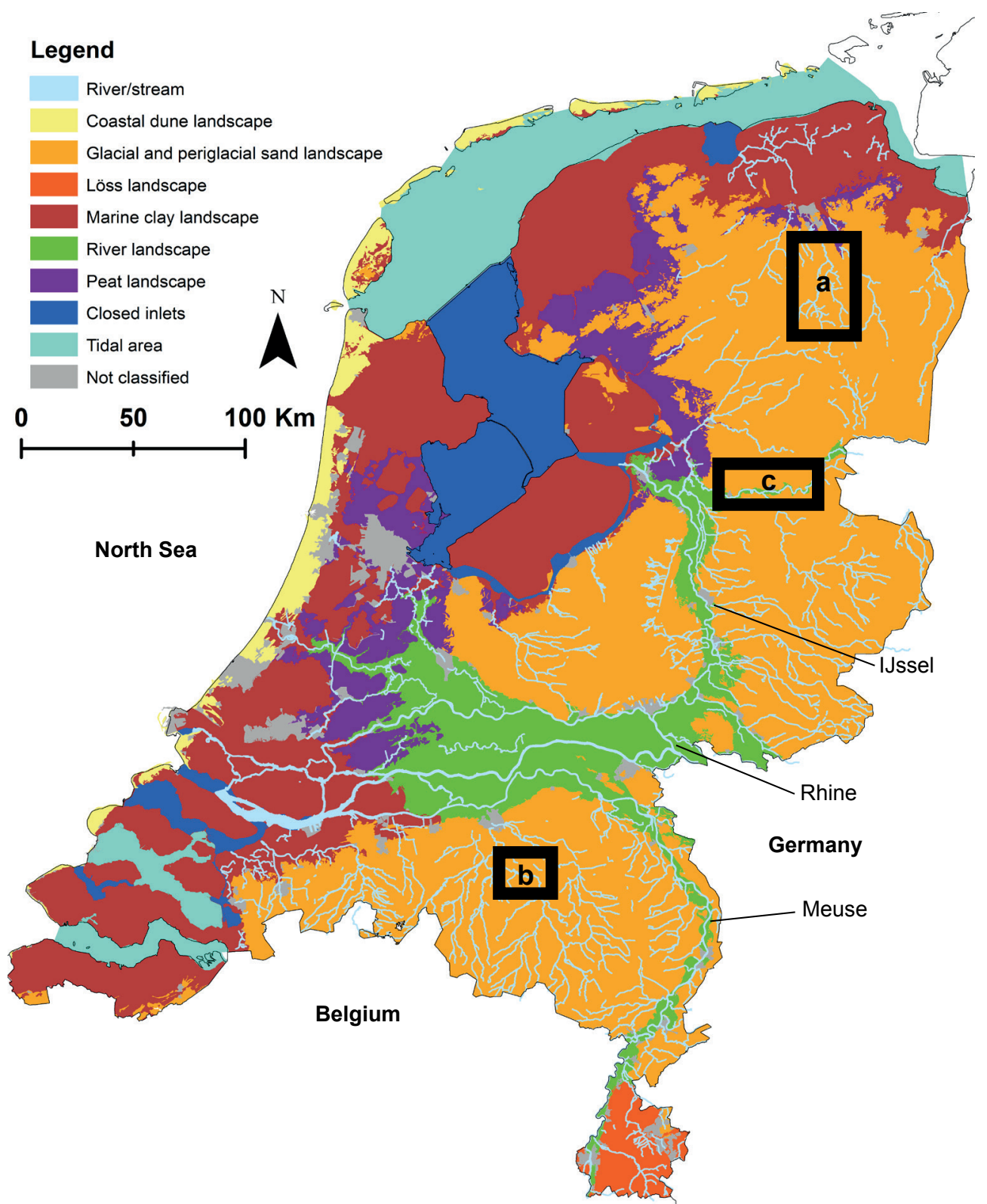

Figure 1.5 Physical-geographical map of The Netherlands, with the study area of a) the Drentsche Aa (Ch. 2), b) the Dommel River (Ch. 3), and c) the Overijsselse Vecht (Ch. 4) (after Makaske and Maas, 2015). 


\section{Chapter I}
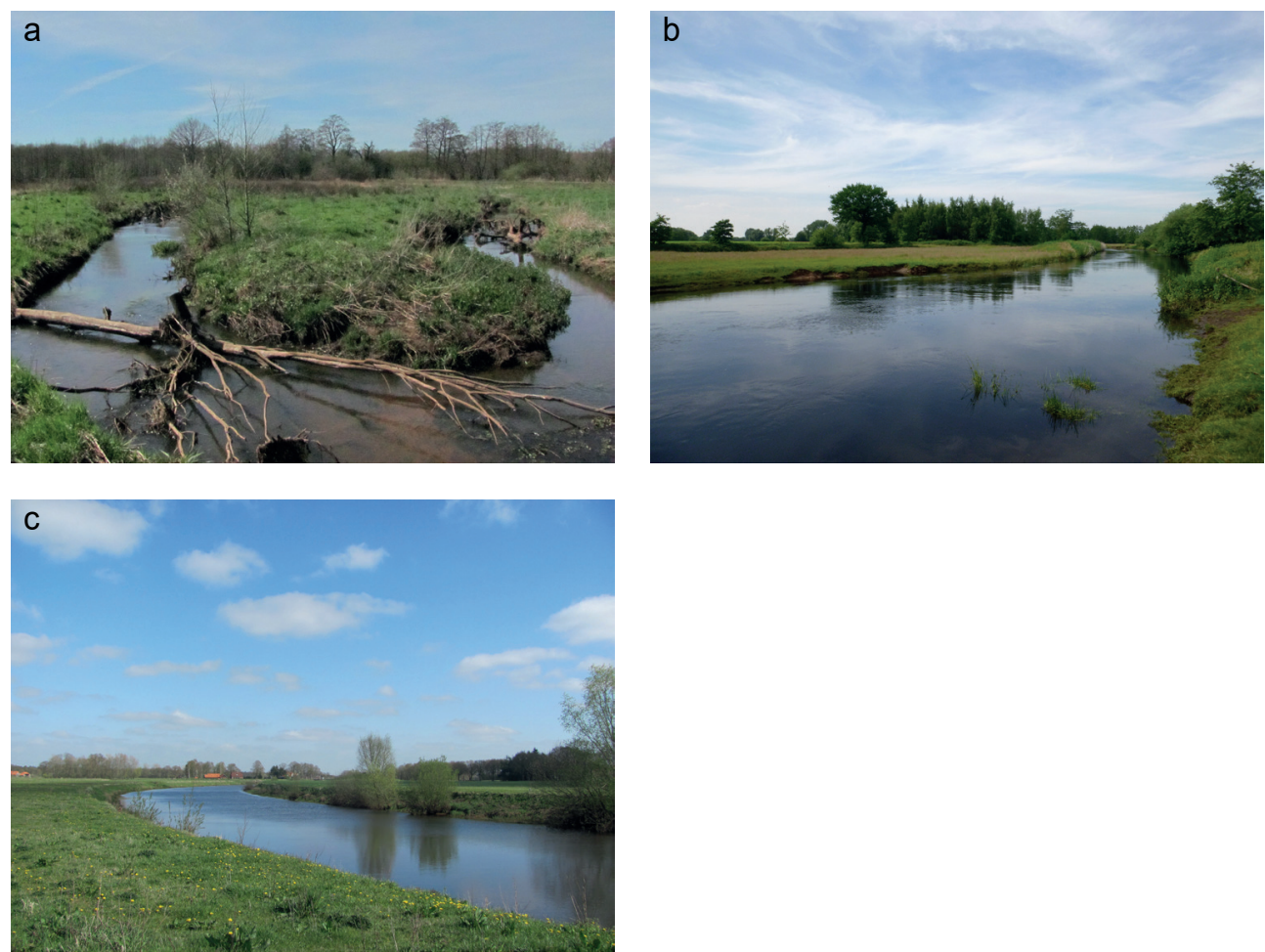

Figure 1.6 The studied rivers, see locations in Figure 1.5, a) the Drentsche Aa (Ch. 2), b) the Dommel River (Ch. 3), c) the Overijsselse Vecht (Ch. 4). 
Table 1.1 Hydrological and morphological characteristics of the case studies. Hydrological data was provided by the waterboard Hunze and Aa (Drentsche Aa), waterboard De Dommel (Dommel), and waterboard Vechtstromen (Overijsselse Vecht).

\begin{tabular}{lccc}
\hline & $\begin{array}{c}\text { Chapter 2 } \\
\text { Drentsche Aa }\end{array}$ & $\begin{array}{c}\text { Chapter 3 } \\
\text { Dommel }\end{array}$ & $\begin{array}{c}\text { Chapter 4 } \\
\text { Overijsselse Vecht }\end{array}$ \\
\hline Hydrology & & & \\
\hline Total length $(\mathrm{km})$ & 26 & 120 & 167 \\
Catchment size $\left(\mathrm{km}^{2}\right)$ & 300 & 1800 & 3785 \\
Mean annual discharge $\left(\mathrm{m}^{3} \mathrm{~s}^{-1}\right)$ & 1.8 & 14 & 22.8 \\
Mean annual flood discharge $\left(\mathrm{m}^{3} \mathrm{~s}^{-1}\right)$ & 14 & 22.3 & 160 \\
\hline Morphology and lithology & & & 100 \\
\hline Channelization (\%) & Ca. 10 & Ca. $40-50$ & $0.14-0.17$ \\
Valley gradient $\left(\mathrm{m}\right.$ km $\left.{ }^{-1}\right)$ & 0.33 & 0.29 & $1.8-2.0$ \\
Sinuosity* & 1.78 & 2.45 & Sand \\
Dominant valley-fill lithology & Peat & Heterogeneous & Sand \\
Dominant valley-side lithology & Sand & Loam & \\
\hline
\end{tabular}

* before channelization 


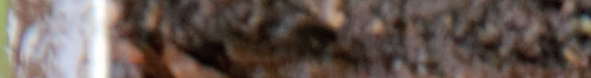

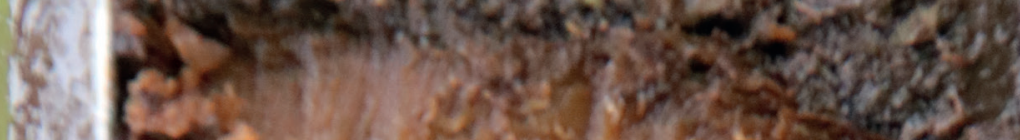 $27 x-4=$

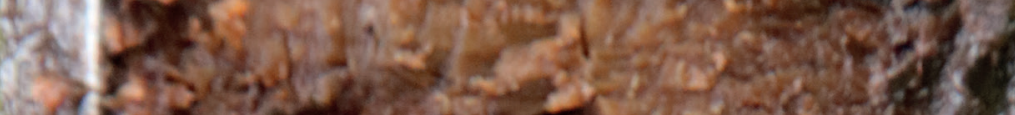

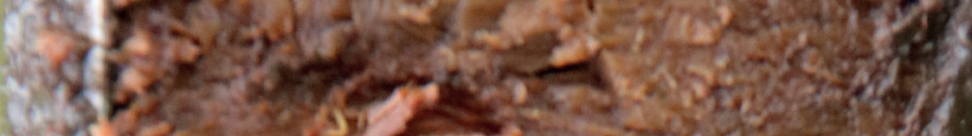

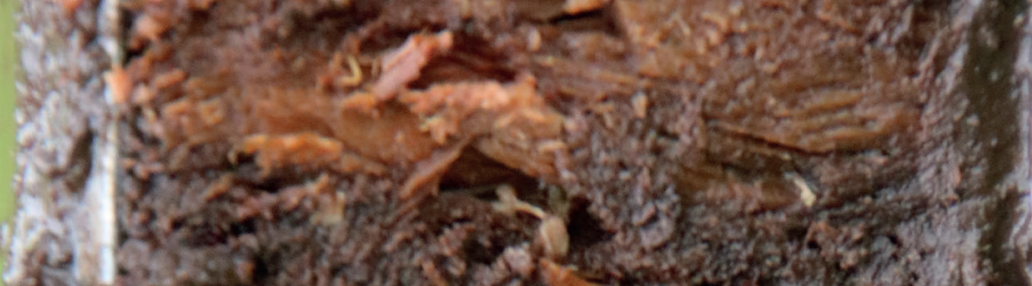

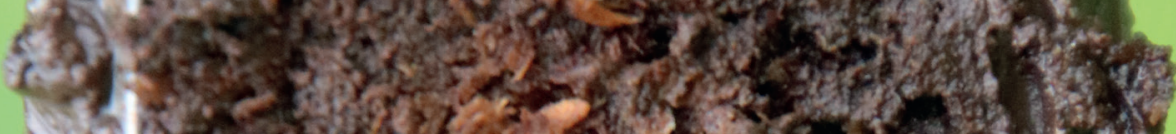

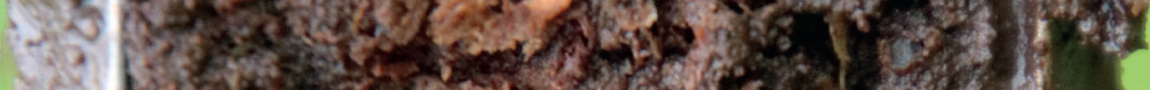
20
4

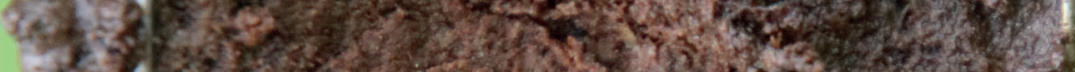

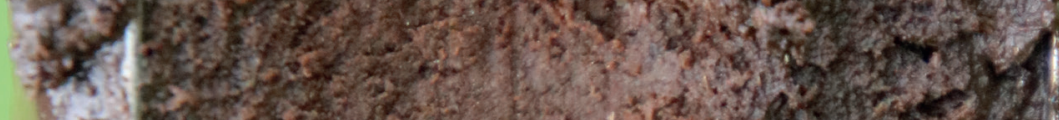

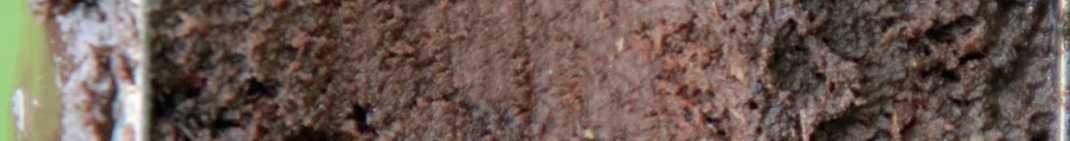

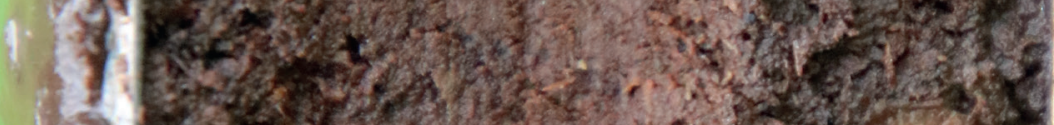

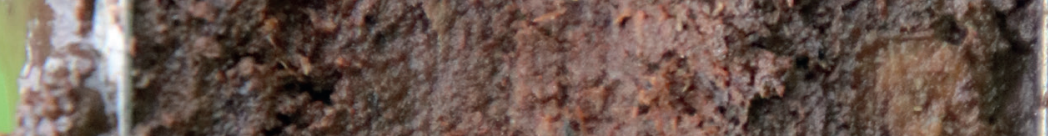

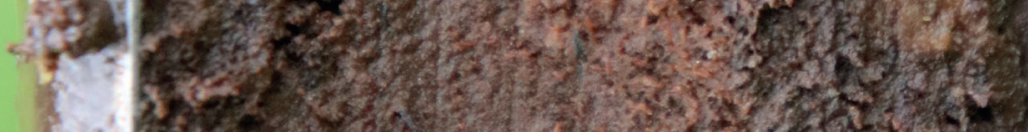

2.

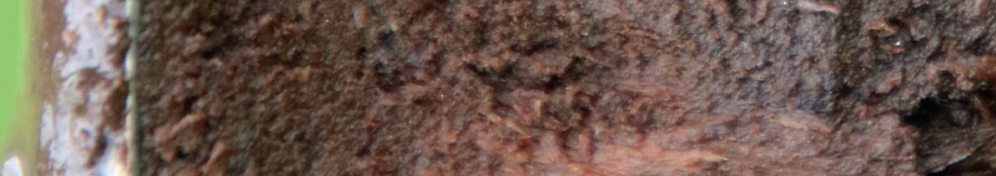

4.

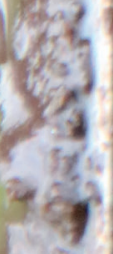

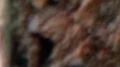

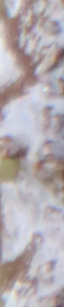

1) a).

$6, \frac{2}{20}$ 1. 390

(y)

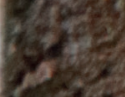
(2)

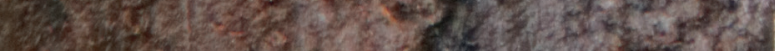

$\sqrt{3}$

26. 


\title{
Chapter 2
}

\begin{abstract}
Oblique aggradation: a novel explanation for sinuosity of low-energy streams in peat-filled valley systems
\end{abstract}




\title{
Chapter 2
}

\begin{abstract}
Low-energy streams in peatlands often have a high sinuosity. However, it is unknown how this sinuous planform formed, since lateral migration of the channel is hindered by relatively erosion-resistant banks. We present a conceptual model of Holocene morphodynamic evolution of a stream in a peat-filled valley, based on a palaeohydrological reconstruction. Coring, ground-penetrating radar (GPR) data, and ${ }^{14} C$ and $O S L$ dating were used for the reconstruction. We found that the stream planform is partly inherited from the Late-Glacial topography, reflecting stream morphology prior to peat growth in the valley. Most importantly, we show that aggrading streams in a peat-filled valley combine vertical aggradation with lateral displacement caused by attraction to the sandy valley sides, which are more erodible than the co-evally aggrading valley fill. Due to this oblique aggradation in combination with floodplain widening, the stream becomes stretched out as channel reaches may alternately aggrade along opposed valley sides, resulting in increased sinuosity with time. Hence, highly sinuous planforms can form in peat-filled valleys without the traditional morphodynamics of alluvial bed lateral migration. Improved understanding of the evolution of streams provides inspiration for stream restoration.
\end{abstract}

Published as: Candel, J. H. J., B. Makaske, J. E. A. Storms, and J. Wallinga, 2017. Oblique aggradation: a novel explanation for sinuosity of low-energy streams in peatfilled valley systems: Earth Surface Processes and Landforms, v. 42, p. 2679-2696. DOI: $10.1002 /$ esp. 4100 


\subsection{Introduction}

Predicting stream morphodynamics is a key aspect in stream restoration projects, in order to prevent flooding or unwanted bank erosion, and to plan and minimize management (Eekhout et al., 2015). Currently, a knowledge gap exists between stream restoration demands and current understanding on the morphodynamic functioning of low-energy streams (Wohl et al., 2005; Walter and Merritts, 2008; Lespez et al., 2015). In many stream restoration projects in lowlands, single-thread, sinuous streams are often seen as "natural" and used as a reference. Sometimes this reference is derived from historical maps (Kondolf, 2006). However, it is often unknown when the sinuous planform formed and whether streams laterally migrated in the past. Some studies found evidence that the sinuous planform of low-energy streams may be the consequence of historical land-use changes that started around the Bronze Age (Broothaerts et al., 2014a; Lespez et al., 2015) or later (Kondolf et al., 2002), or may be the result of historical water engineering (e.g. for watermills) (Walter and Merritts, 2008). Since morphodynamic processes in low-energy streams are slow, these processes should be studied on a longer timescale using palaeohydrological approaches in order to constrain future morphological stream behaviour (Grabowski et al., 2014). Palaeohydrology is defined as "the study of fluvial processes and their hydrological implications before the onset of instrumental records" (Thorndycraft, 2013), and is becoming a more important discipline needed to understand and manage rivers and streams (Sear and Arnell, 2006). The discipline has made considerable progress in developing relevant knowledge and tools for water managers (Brierley and Fryirs, 2000; Kondolf et al., 2003b).

There are several types and settings of low-energy streams (Kondolf et al., 2003a). Here we use a recent classification scheme for European streams by Gurnell et al. (2014) that builds on the classification scheme by Nanson and Croke (1992). They define lowenergy streams as those having a specific stream power of less than $10 \mathrm{~W} \mathrm{~m}^{-2}$. Low-energy streams can be divided into anabranching streams and single-thread streams, and can further be subdivided into streams with inorganic floodplains (e.g. Brown and Keough, 1992; Notebaert and Verstraeten, 2010; Eekhout et al., 2015) and organic floodplains, i.e. peatlands (e.g. Prosser et al., 1994; Gradziński et al., 2003; Watters and Stanley, 2007; Nanson, 2009). Low-energy streams are often classified as non-dynamic, with a stream power too limited to induce morphodynamic processes (Kleinhans et al., 2009; Kleinhans and Van den Berg, 2011; Eekhout et al., 2014), especially in peatlands, since peatbanks are relatively erosion-resistant (Micheli and Kirchner, 2002a, b; Gradziński et al., 2003; Nanson, 2010; Stenberg et al., 2015). At the same time, peatland streams often have a high sinuosity and tight meander bends (Jurmu and Andrle, 1997), but the morphodynamics of such systems has received little attention to date. 
In general, hydraulic processes are responsible for the in-channel morphology (Nanson, 2010; Nanson et al., 2010), in some cases in combination with biological processes by plants and their non-degrading remnants which may build and stabilize the channel banks (Gradziński et al., 2003; Watters and Stanley, 2007; Gurnell, 2014). Although both processes also act in peatland streams, their relative importance will be different. Traditionally deployed fluid mechanics and empirical geomorphic rules of self-adjusting channels in clastic alluvium seem invalid and should not be applied in peatland streams (Jurmu, 2002; Nanson, 2009; Nanson, 2010; Nanson et al., 2010). Even though sinuous channels are often found in peatlands, it is unknown how and why the sinuous planform evolved and whether the sinuosity is a result of lateral migration of channels (Gradziński et al., 2003; Nanson and Cohen, 2014). Nanson and Cohen (2014) argue that the steep, stable peat-banks result in high flow-efficient channels. They also argue that the tight meander bends in these sinuous channels are therefore formed to consume the surplus stream power by the creation of secondary currents and turbulence, hence peatland systems attain equilibrium. However, this process does still not explain how, when and at what rate these bends were formed.

Brown and Keough (1992) and Brown et al. (1994) showed that the sinuous planform of low-energy streams in the United Kingdom was inherited from former river styles. They found evidence that the pattern of stream channels changed during the Holocene from braiding rivers into anastomosing rivers, and later into single-thread, laterally stable channels ('stable bed aggrading banks' model). Similarly, such a pattern shift might explain sinuous yet laterally stable channels in peatlands, where the stream planform is inherited from the period prior to peat growth. In addition, it is debated whether natural low-energy systems in peatlands always have had a channel, or that drainage may also have been dispersed in a wetland system. The latter seems to have been the case during the Middle Holocene in some lowland valleys (Nanson, 2009; Broothaerts et al., 2014a; Lespez et al., 2015), although it is not clear whether that was a common or an exceptional phenomenon.

The aim of this research is to identify the mechanisms that lead to the formation of highly sinuous planforms in low-energy streams in a peat-filled valley. Our study involves a detailed palaeohydrological reconstruction of the morphodynamic evolution of a peatland stream during the Holocene. We present a new conceptual model for stream planform evolution in this setting, and discuss the implications for streams in similar systems and for future management of these stream types. 


\subsection{Study Area}

A study area was chosen where peat growth occurred during the entire Holocene, to cover a long time period with conditions similar to the present. In addition, this area should have a stream that has never been channelized (and also not restored) to relate the present stream morphology to the past morphodynamic functioning. The Drentsche Aa in the northeastern Netherlands (Figure 2.1) fitted these criteria.

The Drentsche Aa is one of the few streams in The Netherlands that has never been channelized and still has a sinuous planform for almost its entire length (De Gans, 1981; Spek et al., 2015). Kuenen (1944) highlighted that morphodynamic processes of meandering are lacking in the nevertheless sinuous Drentsche Aa, a finding recently corroborated by a study of historical maps from 1650 to 1900 AD (Menting and Meijles, 2019). The Drentsche Aa catchment $\left(300 \mathrm{~km}^{2}\right.$, Figure 2.1$)$ is located within subglacially deformed till ridges of the Drenthe till plateau formed 150.000 to 160.000 years ago (Van den Berg and Beets, 1987; Busschers et al., 2008). The formation of the valleys was the result of fast surface runoff of snow meltwater under permafrost conditions during the Weichselian (De Gans, 1981). Coversands were deposited over a large part of the area during this period, reaching thicknesses of 0.5 to $2 \mathrm{~m}$. From the late Weichselian and during the Holocene, the valleys filled with peat, with thicknesses locally reaching up to $7 \mathrm{~m}$ (Makaske et al., 2015). Nowadays, the Drentsche Aa is a lowenergy stream with a mean annual discharge of $1.8 \mathrm{~m}^{3} \mathrm{~s}^{-1}$, a stream power of $0.5 \mathrm{~W} \mathrm{~m}^{-2}$, and the floodplain elevation varies from $16 \mathrm{~m}+\mathrm{NAP}$ (Dutch Ordnance Datum, $\approx$ sea level) to $0.7 \mathrm{~m}+\mathrm{NAP}$. Most of the catchment area is a national park since 1965, a Unesco Global Geopark since 2015, and functions as a nature conservation reserve with forest and meadows. The land use around the national park is forest and agriculture (cattle and arable farming). The groundwater use for drinking water purposes was limited since 1989, to prevent additional peat oxidation in the valleys (Meijles, 2015).

Six locations were chosen along the Drentsche Aa for our study (Figure 2.1). These locations were selected based on equal coverage of the catchment, minimum signs of human disturbance and covering both straight reaches and bends. Three of these sites were part of a previous investigation providing dating and coring data for the locations Loon, Kappersbult and Amen (Makaske et al., 2015). Additional locations were at Schipborg, and two locations at Gasteren (Gasteren1 and Gasteren2). The Gasteren sections are on a tributary of the Drentsche Aa (Figure 2.1). Figure 2.2 shows the digital elevation models (DEM, Actueel Hoogtebestand Nederland, 0.5 x 0.5 m) (Van Heerd and Van't Zand, 1999) for all locations. The Drentsche Aa has a width of approximately $3 \mathrm{~m}$ at the most upstream location in Amen, in comparison to a width of approximately $15 \mathrm{~m}$ at Kappersbult. 


\section{Chapter 2}

a

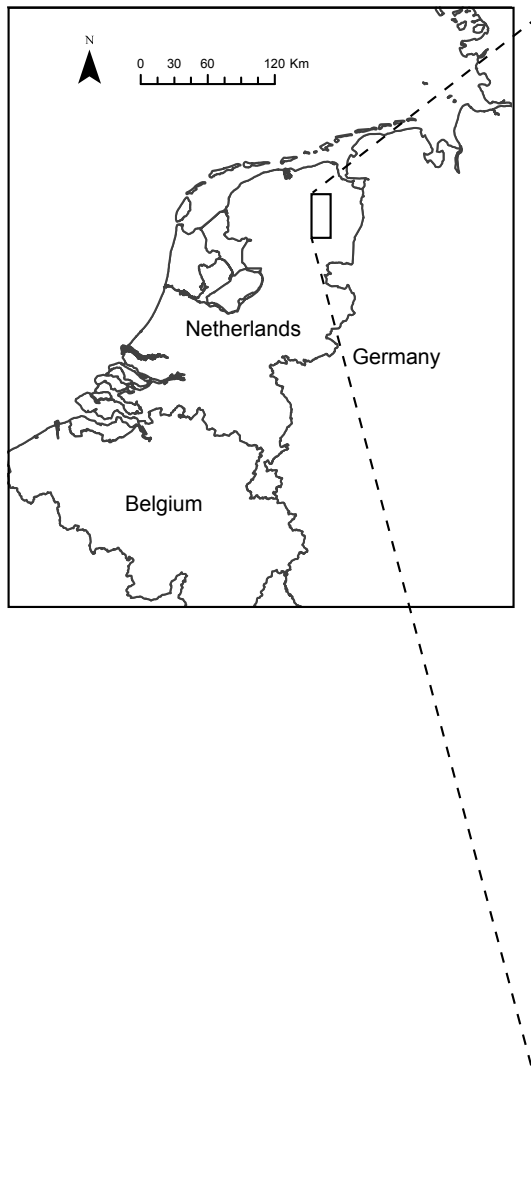

b

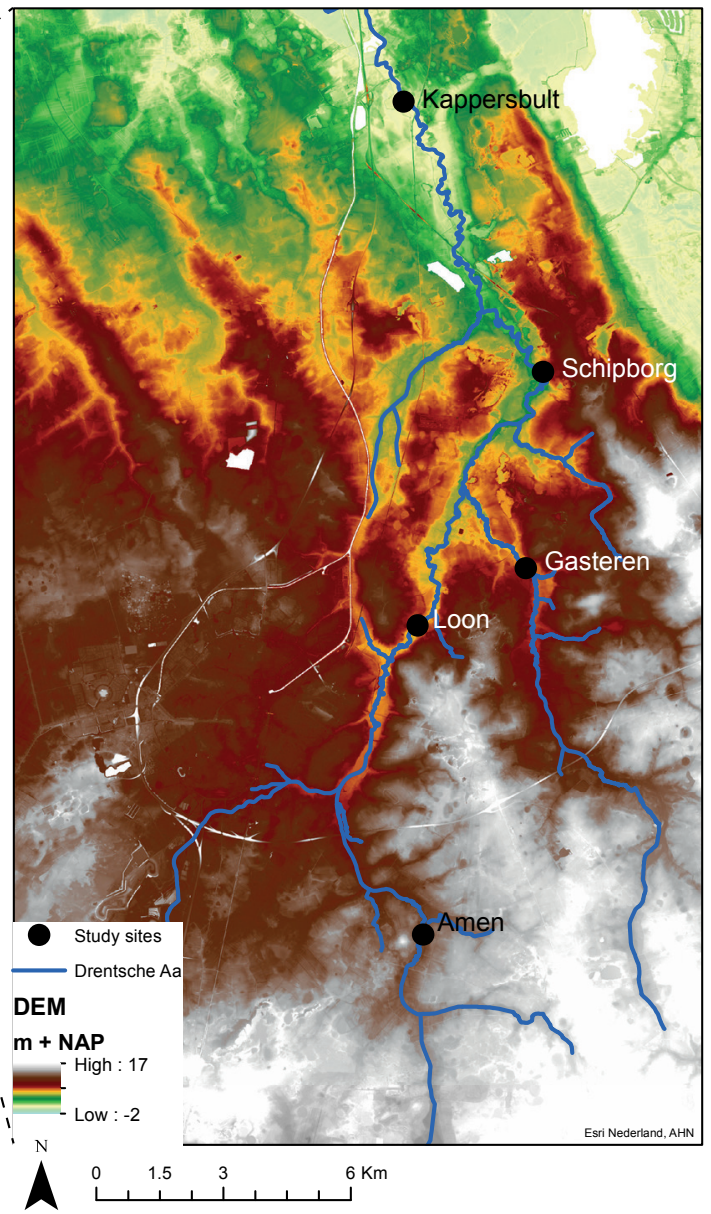

Figure 2.1 Map of the study area. a) The Drentsche Aa is located in the northeastern Netherlands. b) A DEM (Van Heerd and Van't Zand, 1999) of the Drentsche Aa catchment, including the locations where the stratigraphic cross-sections were made. At Gasteren, two stratigraphic cross-sections were made (Gasteren1 and Gasteren2).

Makaske et al. (2015) studied the peat growth rate in the Drentsche Aa valley by radiocarbon $\left({ }^{14} \mathrm{C}\right)$ dating of in-situ peat. All their samples were taken on the sandy Pleistocene valley side to minimize the effects of peat compaction on the reconstruction of past water table heights. The ${ }^{14} \mathrm{C}$ data and the absence of layers with strongly degraded peat indicate continuous peat formation, and thus groundwater-level rise, since the Late Glacial until the Middle Ages (Makaske et al., 2015). 


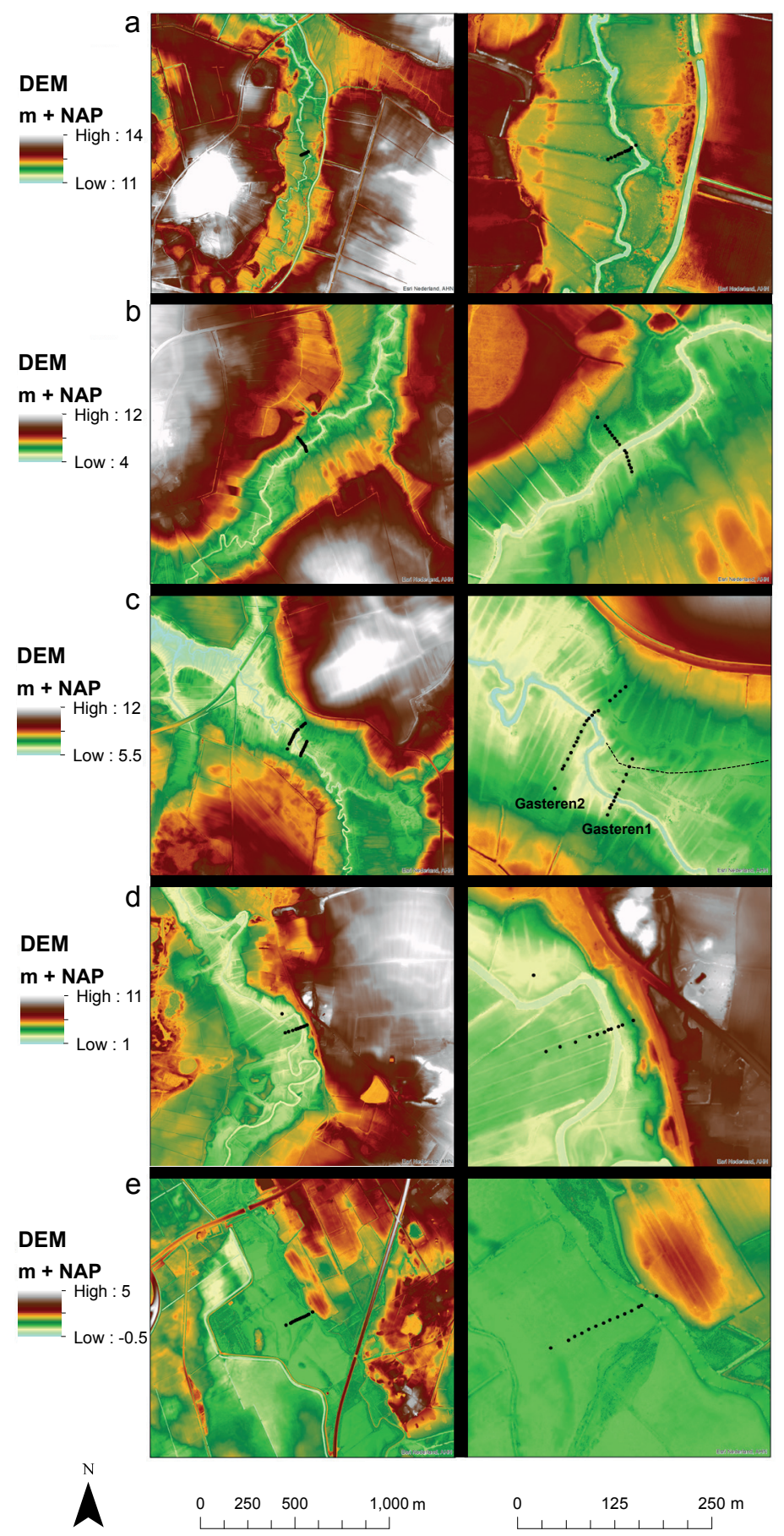

Figure 2.2 DEM of all study locations, including the coring locations. All locations are shown in two different scales (left \& right). a) Amen, b) Loon, c) Gasteren1 (east) \& Gasteren2 (west), dashed line indicates the tributary channel found in cross-section Gasteren1, d) Schipborg, and e) Kappersbult. 


\subsection{Methodology}

\subsubsection{Lithological description}

Six transects were cored with a gouge auger $(\varnothing: 3 \mathrm{~cm})$. The transects were planned using the DEM, and were placed perpendicular to the stream. The transects were located such that the entire floodplain was included. The coring depth varied depending on the depth of the underlying Pleistocene deposits, but did not exceed $8 \mathrm{~m}$. Coring spacing was 5 to $10 \mathrm{~m}$ near the current stream, to ensure that all potential channel deposits were sampled, taking into consideration the dimensions of the palaeochannels. The surface elevation of each borehole was measured with a Global Navigation Satellite System (GNSS) device, with a vertical accuracy of approximately 1 to $2 \mathrm{~cm}$. Additional coring data of 2003, 2009 and 2010 was available at Loon, Kappersbult and Amen from Makaske et al. (2015). For one site, the original lithological data of one coring was derived from DINOLoket, a national geological borehole database (TNO, 2015), because we could not access the field site. The section Gasteren1 was difficult to auger, due to the extremely wet surface conditions. Auger points at this location had to be selected based on the terrain accessibility.

A standard method was used to describe the sediment cores in 10-cm-thick intervals (Berendsen and Stouthamer, 2001). The sediment texture $\left(D_{50}\right)$ of non-organic, sandy samples was visually determined in the field by comparison with a sand ruler. Organic samples were visually checked in the field for the presence of sand or loam. At all locations the plant macro-remains were described.

\subsubsection{GPR}

Ground Penetrating Radar (GPR) proved to be successful in previous studies in peatlands (Lowry et al., 2009; Proulx-McInnis et al., 2013; Pîrnău et al., 2015). GPR is suitable to detect layers that have a different bulk density and humification, so it was expected that sand layers within the peat could also be detected (Lapen et al., 1996; Van Overmeeren et al., 1997; Pîrnău et al., 2015). GPR measurements were conducted with a pulseEKKO PRO $200 \mathrm{~Hz}$ and $250 \mathrm{~Hz}$ with a SmartTow configuration. The GPR was used to cover four of the six cored transects. The other locations were too wet to use GPR (Gasteren1), or contained too much clay resulting in attenuating signals (Kappersbult). The GPR signal reached a depth of approximately $3 \mathrm{~m}$ in the peat-filled valley of the Drentsche Aa. The high groundwater levels result in high attenuation of radar signals and limited penetration depth (Wastiaux et al., 2000; Neal, 2004). In the Drentsche Aa valley different lithologies are present in the subsurface, affecting the electromagnetic-wave velocity that determines the depth of attenuation. In freshwater peat the wave has a velocity of 0.03 to $0.06 \mathrm{~m} \mathrm{~ns}^{-1}$, while in saturated sand the wave has a velocity of 0.05 to $0.08 \mathrm{~m} \mathrm{~ns}^{-1}$ (Neal, 2004). The actual velocity was derived 
from the GPR profiles by using isolated reflector points (Neal, 2004), and was in all profiles between 0.054 and $0.060 \mathrm{~m} \mathrm{~ns}^{-1}$. Since the GPR is primarily used to determine the shapes and continuity of lithological layers, the GPR profiles were not corrected for the heterogeneous electromagnetic velocity speeds and slight undulations of the surface elevation. The GPR profiles were interpreted based on expert judgement, and provided insight into the approximate depths and geometry of the lithological features for the upper $3 \mathrm{~m}$. This insight helped to infer the lithogenetic cross-sections from the lithological cross-sections which are based on the coring data.

\subsubsection{OSL dating}

Optically stimulated luminescence (OSL) dating is a powerful tool in dating sediments from a wide range of depositional environments (Wallinga et al., 2007). OSL dating determines the last exposure to light of mineral grains (here sand-sized quartz), and thus determines the time of deposition and burial of sediments (e.g. Preusser et al., 2008). Four samples for Optical Stimulated Luminescence (OSL) were taken to determine the burial age of sandy deposits within the valley fill at Schipborg. The OSL samples were taken at different depths in a single borehole at $30 \mathrm{~m}$ from the stream using a Van der Staay suction corer (Van de Meene et al., 1979; Wallinga and Van der Staay, 1999) for saturated sand, or a modified hand-auger in unsaturated conditions. Both methods use a PVC-tube $(\varnothing 4-4.5 \mathrm{~cm})$ to collect the samples, which ensures that samples are not exposed to light during sampling. The OSL age was determined at the Netherlands Centre for Luminescence dating. In the laboratory, the outer $3 \mathrm{~cm}$ of all samples was removed and a sample of 300 to 500 gram was left for the analysis and split into two parts under orange/amber safelights. One part was prepared for dose rate analysis and the other part for equivalent dose estimation.

Bulk samples were dried for 24 hours at $105^{\circ} \mathrm{C}$, weighed, and ashed for 24 hours at $500{ }^{\circ} \mathrm{C}$; water and organic content was determined during this procedure. The sample was grinded and cast in wax to ensure radon retention, and radionuclide concentrations were measured using a broad-energy gamma spectrometer. Dose rates were calculated using conversion factors of Guérin et al. (2011) taking into account contributions from cosmic rays (Prescott and Hutton, 1994), as well as attenuation by water, organics and grain size (Aitken, 1985; Madsen et al., 2005).

Quartz extracts of coarse grains $(212-250 \mu \mathrm{m})$ were obtained through sieving and treatment with $\mathrm{HCl}, \mathrm{H}_{2} \mathrm{O}_{2}$ and $\mathrm{HF}$. For each sample, small aliquots ( $2 \mathrm{~mm}$ diameter) were prepared on stainless-steel discs sprayed with a thin layer of silicon spray. Measurements were performed on a Risø TL/OSL DA20 reader (Bøtter-Jensen et al., 2003), using the Single-Aliquot Regenerative dose (SAR) protocol (Wintle and Murray, 2006). A 
relatively low preheat of $200{ }^{\circ} \mathrm{C}$ and cutheat of $180{ }^{\circ} \mathrm{C}$ were used, to prevent thermal transfer effects. Early background subtraction was used to maximize the contribution from the quartz fast-OSL component (Cunningham and Wallinga, 2010). Around 45 aliquots were measured per sample.

A bootstrapped version of the Minimum Age Model (Galbraith et al., 1999; Cunningham and Wallinga, 2012) was used to estimate burial doses from scattered equivalent dose distributions, assuming an overdispersion of $20 \pm 5 \%$ not related to heterogeneous bleaching (Cunningham et al., 2011). Burial ages were determined by dividing the equivalent dose by the dose rate, taking all uncertainties in both into account. Results are reported with 1-sigma errors.

\subsection{4 ${ }^{14} \mathrm{C}$ dating}

First we briefly describe the methods used by Makaske et al. (2015) for collecting and dating peat samples. Their samples were taken at the sand-peat interface with a gouge auger $(\varnothing: 4 \mathrm{~cm})$. In the laboratory, the sample was cut in 1 -cm-thick slices and sieved with a mesh size of $180 \mu \mathrm{m}$. Suitable material was selected by using a microsope and samples were stored in diluted $\mathrm{HCl}$. Terrestrial macro-remains such as leaves and seeds were preferably used for the analysis to prevent an under- or overestimation of the ${ }^{14} \mathrm{C}$ age (Mook and Streurman, 1983; Törnqvist et al., 1992). However, due to the lack of recognizable macro-remains also wood or un-recognizable plant remains were used. From the residue and filtrate the sand content was determined. The sand-peat interface was based on a volumetric sand content lower than 10 to $20 \%$. The macro-remains from the centimeter above this interface were selected for the ${ }^{14} \mathrm{C}$ analysis. In total 15 samples of selected macro-remains were dated at the Accelerator Mass Spectrometry (AMS) facility of the Leibniz Laboratory for Radiometric Dating and Stable Isotope Research. For calibration, the IntCal9 curve was used in the Wincal25 software (Van der Plicht, 2005; Reimer et al., 2009).

One additional sample for ${ }^{14} \mathrm{C}$ analysis was taken in this study from terrestrial macroremains (alder wood) in the same borehole as the OSL samples, below the sedimentary unit at a depth of $420 \mathrm{~cm}$ (Figure 2.7a). The matrix around the alder wood had all characteristics of the described lithogenetic in-situ peat unit (see lithogenetic unit description). The ${ }^{14} \mathrm{C}$ age was determined by AMS at the Centre for Isotope Research (Groningen University). For calibration, the IntCal13 curve was used in the OxCal4.2.4 software (Bronk Ramsey, 2009; Reimer et al., 2013). 


\subsubsection{Inferences on lithogenesis}

The cross-section figures are set up with different panels, starting with a geological overview cross-section (after Makaske et al., 2015), followed by a lithological, an interpreted GPR, and a lithogenetic cross-section (Figures 2.3 to 2.8), if all these data were present for the specific location. The lithogenetic cross-sections are constructed based on the combination of all the available information for each section. The first step was to distinguish units based on their lithology and additional characteristics found during the coring, e.g. presence of macro-remains or layering. The second step was combining this information with the extent and shape of each unit, obtained through closely spaced cores and GPR data for the upper three metres (original GPR profiles in Appendix 1). The DEM was also used for the near-surface stratigraphy, since surface elevations can help in identifying morphological features. For example, old channel beds or overbank deposits were easily recognized from the GPR and DEM by their geometry, which in combination with the lithology from the boreholes helped in distinguishing the units in the lithogenetic cross-sections. The last step involved using the OSL and ${ }^{14} \mathrm{C}$ data (Tables 2.1 and 2.2 ) to validate the stratigraphical order of the lithogenetic units at Schipborg. ${ }^{14} \mathrm{C}$ ages from the valley fill at the palaeovalley margins provide information on timing and rate of peat development in the valley. However, due to differential compaction related to valley shape and loading effects, isochrones are not expected to be horizontal. 


\section{Chapter 2}

W

E

a

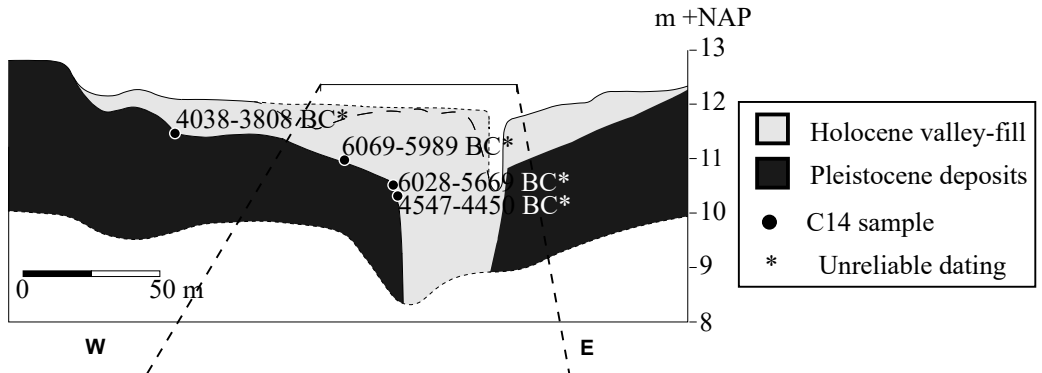

b
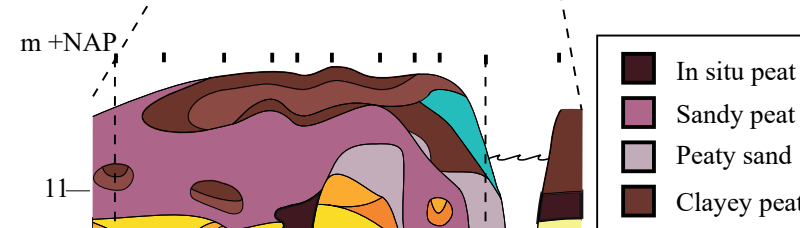

C
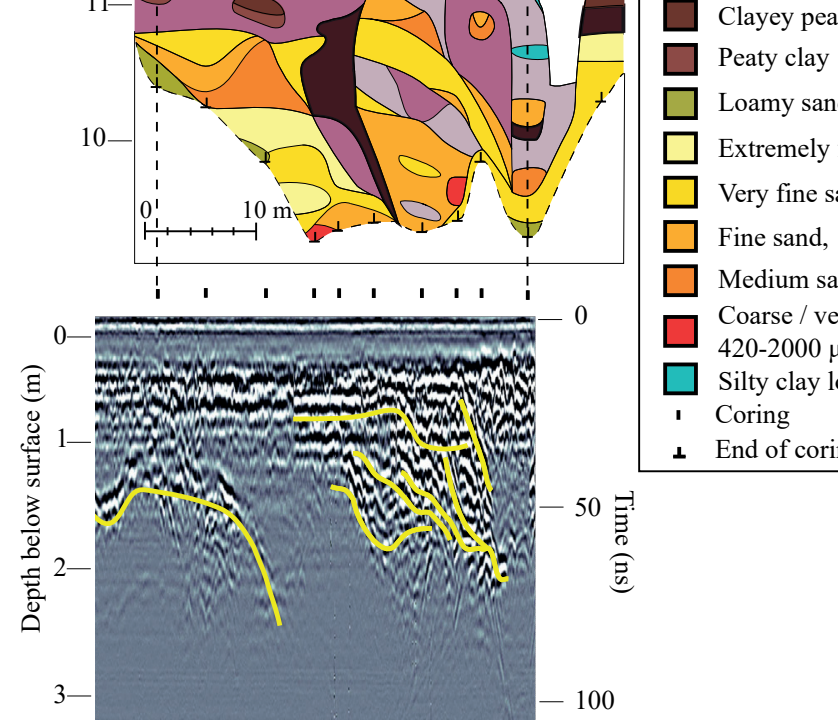

10

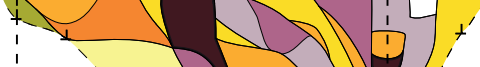

-

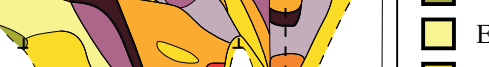

Loamy sand

$\square$ Extremely fine sand, $75-105 \mu \mathrm{m}$

$\square$ Very fine sand, $105-150 \mu \mathrm{m}$

$\square$ Fine sand, $150-210 \mu \mathrm{m}$

$\square$ Medium sand, $210-420 \mu \mathrm{m}$

Coarse / very coarse sand,

$420-2000 \mu \mathrm{m}$

$\square$ Silty clay loam / clay loam

I Coring

- End of coring

d

W

\section{官}

Lithogenetic units

$\square$ In-situ peat

Fluvial deposits

Older deposits

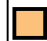

Figure 2.3 Amen: a) Geological cross-section of the valley (modified after Makaske et al., 2015) b) lithological cross-section of the valley fill, c) GPR profile of the west side of the stream, d) lithogenetic cross-section of the valley fill. Letter $\mathrm{O}$ indicates overbank deposits. Letter $\mathrm{C}$ indicates channel deposits. 


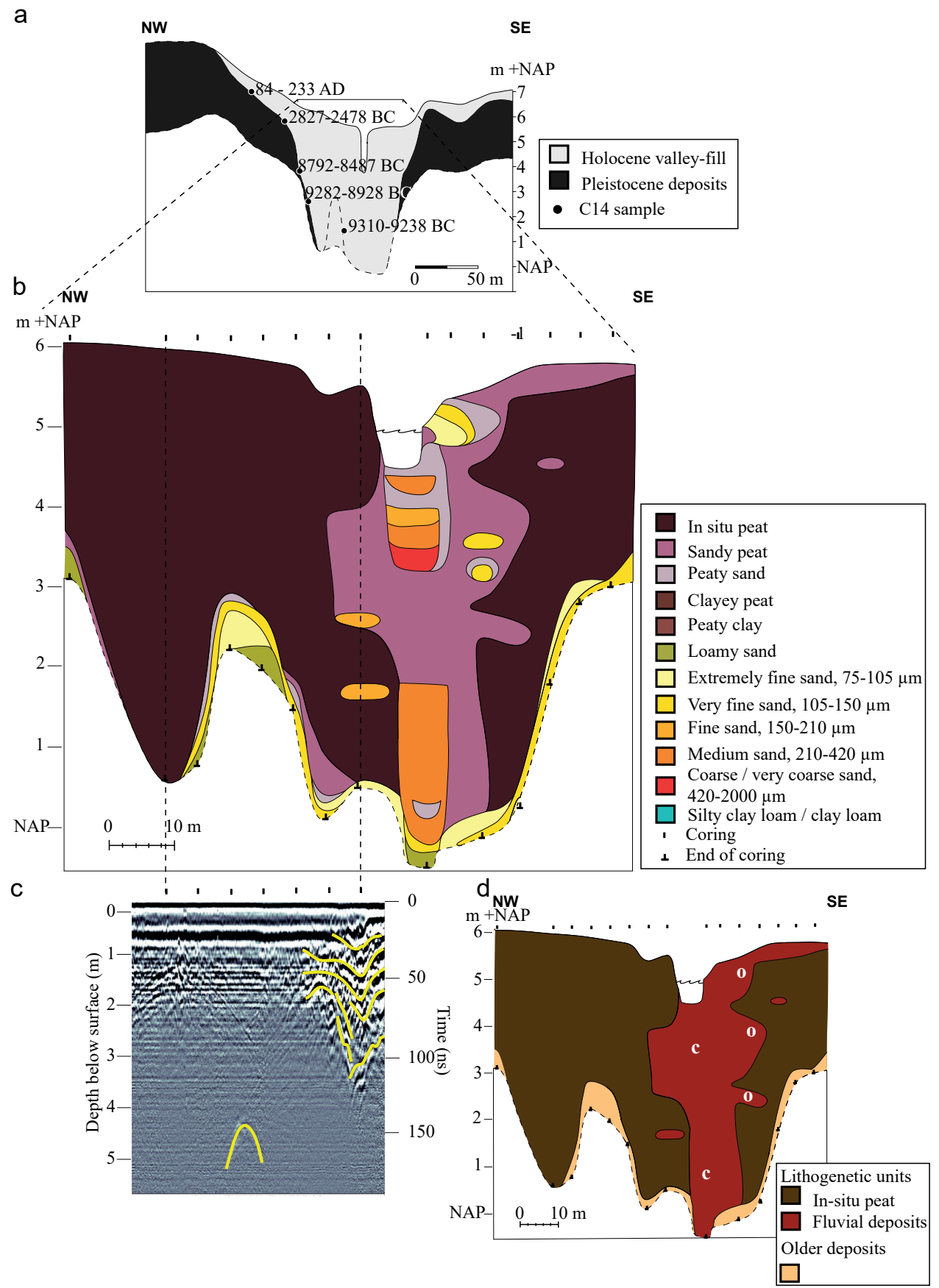

Figure 2.4 Loon: a) Geological cross-section of the valley (modified after Makaske et al., 2015) b) Lithological cross-section of the valley fill, c) GPR profile of the west side of the stream, d) lithogenetic cross-section of the valley fill. Letter $\mathrm{O}$ indicates overbank deposits. Letter $\mathrm{C}$ indicates channel deposits. 


\section{Chapter 2}

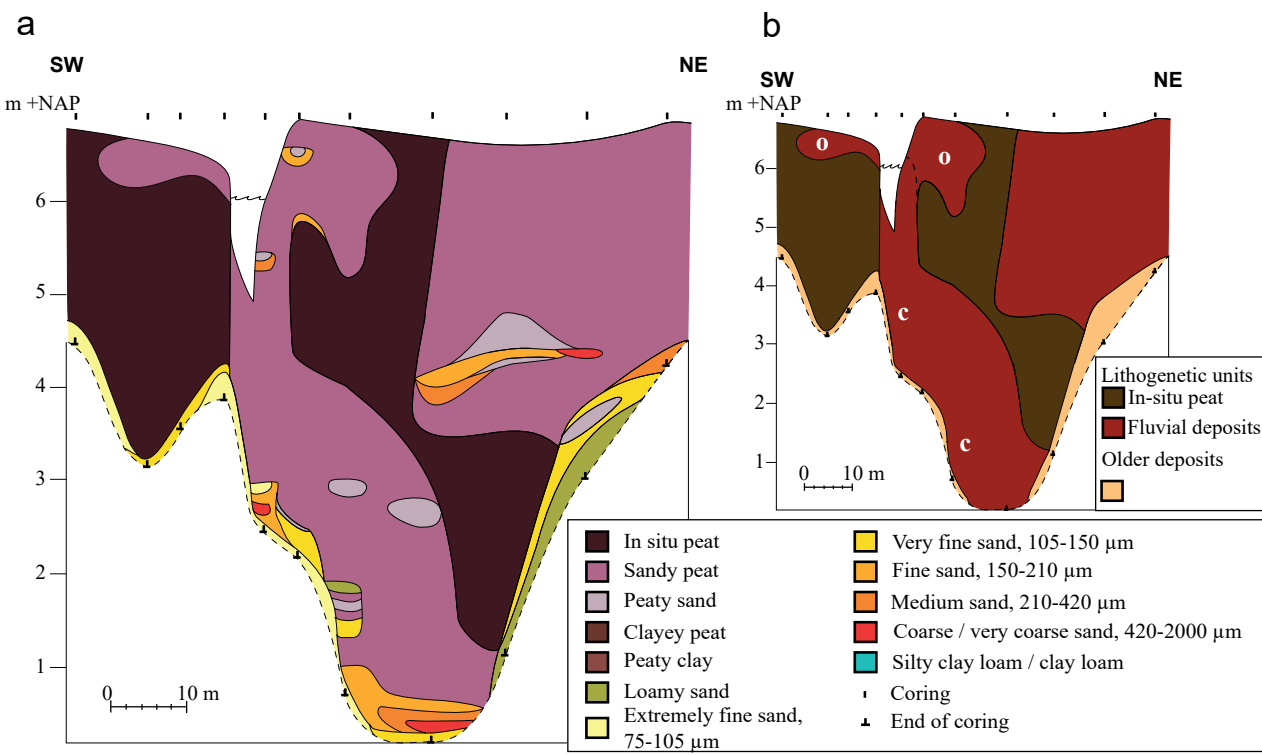

Figure 2.5 Gasteren1: a) Lithological cross-section of the valley fill, b) lithogenetic cross-section of the valley fill. Letter $\mathrm{O}$ indicates overbank deposits. Letter $\mathrm{C}$ indicates channel deposits. 


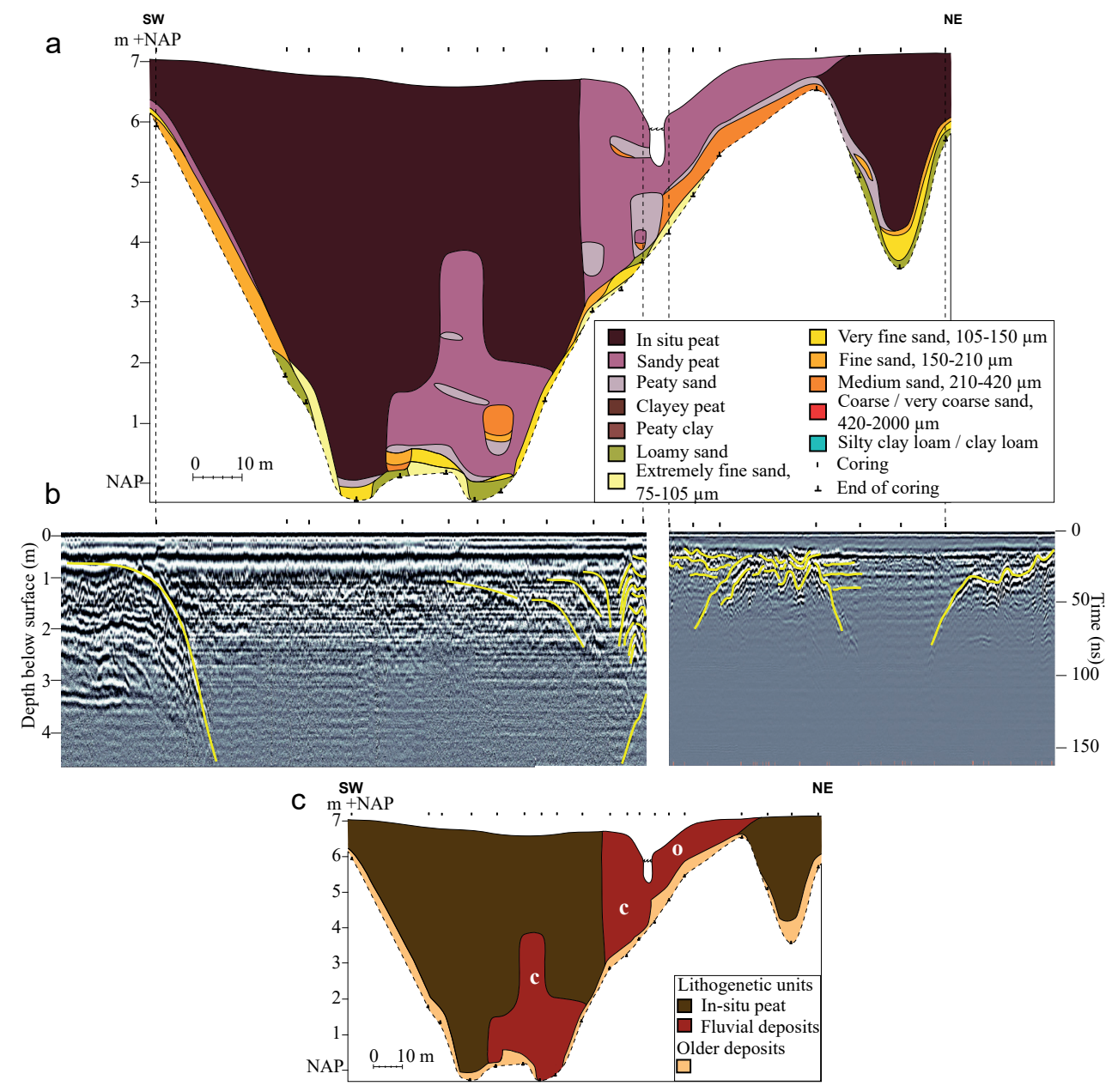

Figure 2.6 Gasteren2: a) Lithological cross-section of the valley fill, b) GPR profile of the west and east side of the stream, c) lithogenetic cross-section of the valley fill. Letter $\mathrm{O}$ indicates overbank deposits. Letter $\mathrm{C}$ indicates channel deposits. 


\section{Chapter 2}

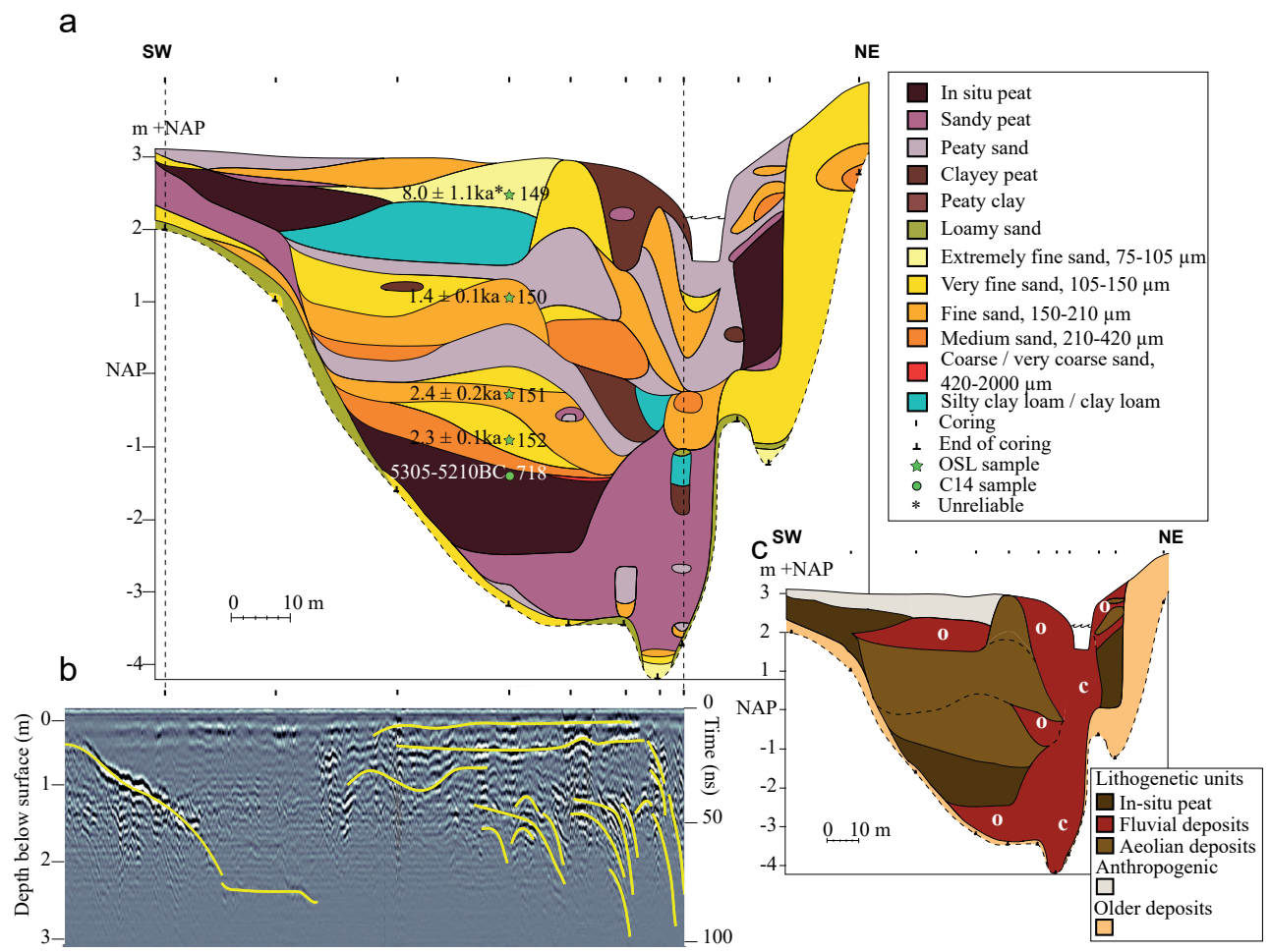

Figure 2.7 Schipborg: a) Lithological cross-section of the valley fill, including the OSL and 14C sample locations, b) GPR profile of the west side of the stream, c) lithogenetic cross-section of the valley fill. Letter $\mathrm{O}$ indicates overbank deposits. Letter $\mathrm{C}$ indicates channel deposits. 


\subsection{Results}

\subsubsection{Lithogenetic units}

In-situ peat contains plant macrofossils, mostly alder and some oak wood, and sedge roots and leafs. Wood pieces can reach thicknesses in boreholes of $0.5 \mathrm{~m}$. The unit does not contain observable clastic sediments. The colour of this lithogenetic unit is dark brown, but turns black when exposed to air. Plant remains are interwoven, resulting in a firm structure. This lithogenetic unit corresponds to the description of in-situ peat by Bos et al. (2012). In-situ peat is mostly found as the matrix in which other lithogenetic units are present.

Fluvial deposits may consist of peat with clastic sediments, but also clay, silt or sand with an extremely fine to coarse texture $(75-600 \mu \mathrm{m})$. The unit can show well developed bedding, varying from several centimeters to several decimeters in thickness. Sometimes a thinning upward succession was recognized. The clastics can be poorly sorted. The colour is light to dark grey when sandy, and dark brown to dark grey when clayey. For the peaty facies, clastics are present throughout the entire peat mass. Plant macrofossils are mostly present, but they are relatively small and fragmented compared to the macrofossils in the in-situ peat unit. Moreover, the macrofossils occur bedded within this unit. The structure is less firm compared to the in-situ peat, as the plant macrofossils are not interwoven. The colour of the peat is dark brown.

Table 2.1 OSL results at $30 \mathrm{~m}$ west of the stream in Schipborg. Lat,Lon (RD): 240983,565193

\begin{tabular}{lccccc}
\hline Sample Code & Material & Depth & Palaeodose & Dose rate & Age \\
\hline & & $(\mathrm{m}+\mathrm{NAP})$ & $(\mathrm{Gy})$ & $(\mathrm{Gy} / \mathrm{ka})$ & $(\mathrm{ka})$ \\
NCL2315149* & Anthropogenic & 2.50 & $9.8 \pm 1.2$ & $1.22 \pm 0.07$ & $8.0 \pm 1.07$ \\
NCL2315150 & Aeolian & 1.10 & $1.4 \pm 0.1$ & $1.01 \pm 0.06$ & $1.4^{*} \pm 0.06$ \\
NCL2315151 & Aeolian & -0.25 & $1.8 \pm 0.1$ & $0.79 \pm 0.03$ & $2.3^{*} \pm 0.08$ \\
NCL2315152 & Aeolian & -0.85 & $1.9 \pm 0.1$ & $0.78 \pm 0.03$ & $2.4 \pm 0.14$ \\
\hline
\end{tabular}

*unreliable dating, this sample has been anthropogenically influenced. 
Chapter 2

Table $2.2{ }^{14} \mathrm{C}$ dating results

\begin{tabular}{lcccccc}
\hline $\begin{array}{l}\text { Sample } \\
\text { Code }\end{array}$ & Material & Depth & ${ }^{14}$ C age & Age & Lat/Lon (RD) \\
\hline & & & & & & \\
& & $(m+N A P)$ & $(a) B P)$ & $(a)$ & AD & \\
KIA-43998* & Wood and bark & 11.45 & $5149 \pm 34$ & $4038-3808$ & BC & $238.099 / 551.890$ \\
KIA-43999* & Wood and bark & 11.13 & $7166 \pm 35$ & $6069-5989$ & BC & $238.157 / 551.908$ \\
KIA-44000* & Wood and bark & 10.61 & $6979 \pm 104$ & $6028-5669$ & BC & $238.173 / 551.914$ \\
KIA-44001* & Wood and bark & 10.44 & $5668 \pm 30$ & $4547-4450$ & BC & $238.176 / 551.915$ \\
KIA-43745 & Plant remains & 11.45 & $1854 \pm 32$ & $84-233$ & AD & $237.992 / 559.305$ \\
KIA-43746 & Plant remains & 5.85 & $4042 \pm 27$ & $2827-2478$ & BC & $238.011 / 559.239$ \\
KIA-43747 & Seeds & 3.82 & $9384 \pm 57$ & $8792-8487$ & BC & $238.018 / 559.275$ \\
KIA-43748 & Bark & 2.63 & $9717 \pm 46$ & $9282-8928$ & BC & $238.023 / 559.270$ \\
KIA-43749 & Bark & 1.46 & $9811 \pm 39$ & $9310-9238$ & BC & $238.041 / 559.248$ \\
KIA_43750 & Seeds & 0.10 & $1135 \pm 42$ & $780-989$ & AD & $237.669 / 571.553$ \\
KIA_43751 & Wood & -0.77 & $2206 \pm 25$ & $361-201$ & BC & $237.675 / 571.557$ \\
KIA_43752 & Buds & -2.32 & $3999 \pm 33$ & $2576-2467$ & BC & $237.680 / 571.559$ \\
KIA_43753 & Reed & -4.32 & $9043 \pm 39$ & $8343-8001$ & BC & $237.687 / 571.562$ \\
KIA_43754 & Seeds & -5.76 & $10266 \pm 58$ & $10.178-9881$ & BC & $237.692 / 571.565$ \\
KIA_43755 & Reed & -3.48 & $7757 \pm 69$ & $6748-6504$ & BC & $237.684 / 571.561$ \\
GrA64718 & Wood & -1.25 & $6250 \pm 40$ & $5305-5210$ & BC & $240.983 / 565.193$ \\
\hline * & & & & & \\
\end{tabular}

*unreliable dating, since this sample turned out to be fluvial reworked peat.

Channel deposits can sometimes be distinguished within the fluvial deposits unit, when the unit has a low width/thickness ratio, consists of the sandy fraction and contain well developed stratification. Overbank deposits can be distinguished within the fluvial deposits unit, when the fluvial deposits consist of the clayey fraction. In addition, bodies of fluvial deposits with a high width/thickness ratio are interpreted as overbank deposits. These bodies are mostly positioned along the channel deposits, within the matrix of peat. Additional letters "O" (overbank) and " $\mathrm{C}$ " (channel) are added in the lithogenetic cross-sections when the geometry allows discriminating these lithogenetic sub-units. The overbank deposits can contain ferruginous concretions, which are irregulary distributed. These concretions were analysed by XRF and consist of $58 \%$ iron oxide (Table 2.3); given the clayey and peaty environment, the concretions likely consist of siderite $\left(\mathrm{FeCO}_{3}\right)$ (Dr. Bertil van Os, personal communication, November 2015). 
Table 2.3 XRF analysis results of concretion sample.

\begin{tabular}{cc}
\hline Type & Amount (\%) \\
\hline $\mathrm{SiO}_{2}$ & 25 \\
$\mathrm{CaO}$ & 1.60 \\
$\mathrm{P}_{2} \mathrm{O}_{5}$ & 0.35 \\
$\mathrm{~K}_{2} \mathrm{O}$ & 0.345 \\
$\mathrm{Al}_{2} \mathrm{O}_{3}$ & 2.57 \\
$\mathrm{TiO}_{2}$ & 0.069 \\
$\mathrm{Fe}_{2} \mathrm{O}_{3}$ & 58 \\
$\mathrm{MnO}$ & 2.39 \\
$\mathrm{Bal}$ & 8.78 \\
\hline
\end{tabular}

Aeolian deposits consist of clastic sediments varying in texture from medium fine sand to fine sand $(150-420 \mu \mathrm{m})$. The sand is well sorted, and plant remains are hardly present. The lithogenetic unit is strongly layered. The colour is light to dark grey. The unit is only encountered at section Schipborg, where it reaches a thickness up to $4 \mathrm{~m}$, and fills the entire valley on one side of the stream. Beds dip towards the stream with an angle of $15-25^{\circ}$, and strongly compacted in-situ peat was found below this deposit. The top of the lithogenetic unit consists of topographic highs and lows with 1 to $1.5 \mathrm{~m}$ difference in elevation. Elevation differences can be recognized at the surface, and the valley is bordered by dunes. Thick aeolian deposits located at the surface are known in this area as drift-sand deposits (Koster et al., 1993).

Older deposits consist of several lithogenetic units and form the palaeovalley. The unit consists of clastic sediment, varying from fine sand to extremely fine sand $(75-210 \mu \mathrm{m})$ and are mostly well sorted. The sand may contain low percentages of loam $(<10 \%)$. At the lowest parts of the palaeovalley the unit can be poorly sorted and contain up to $10 \%$ gravel. The unit is easily distinguishable from the other lithogenetic units by its lightgrey colour, its strong consolidation, some thin soil formation, and sometimes a sharp transition with the other units. Plant remains are mostly absent. The older deposits largely consist of aeolian sands (coversand) on the valley sides, and fluvial periglacial sands in the valley (De Gans, 1981). No distinction was made, as our interest is in the Holocene deposits of the valley fill. 


\subsubsection{Cross-sections}

At Amen (Figure 2.3) the palaeovalley is relatively shallow, with a minimum depth of $3 \mathrm{~m}$. The valley fill mainly consists of fluvial deposits, and small amount of in-situ peat. The ${ }^{14} \mathrm{C}$ ages of Makaske et al. (2015) were in non-stratigraphical order. Our results indicate that this may be due to dating overbank deposits rather than in-situ peat. At Loon (Figure 2.4) the channel deposits are located in the middle of the palaeovalley with in-situ peat on both sides. At Gasteren1 (Figure 2.5) the channel deposits are located along the southwestern palaeovalley side. Fluvial deposits are also located at the northeastern side of the palaeovalley. From the DEM (Figure 2.2c, dashed line) it can be derived that these are remainders of an abandoned stream that is not visible in the field. The palaeovalley in Gasteren2 (Figure 2.6) is wider compared to Gasteren1. Channel deposits are located in the middle of the palaeovalley below $2.8 \mathrm{~m}$ below the surface. Above that level, they are covering the northeastern palaeovalley side. The Schipborg section (Figure 2.7) differs from the other sections in the presence of aeolian deposits on top of the peat. Dune deposits (fine sands) are interbedded with fluvial overbank interdune deposits (clay, reworked plant remains) in the lows, similar as presented in the conceptual model of Langford (1989) and stratigraphy of Langford and Chan (1989). A borehole $100 \mathrm{~m}$ farther downstream did not contain this aeolian unit, indicating how local these deposits are (Figure 2.2d). The drift-sand activity seems to have started $2.4 \mathrm{ka}$ ago and was probably strongly related to human activity in the area (Derese et al., 2010; Sevink et al., 2013; Jager, 2015). Another phase was dated at the start of the Middle Ages, $1.4 \mathrm{ka}$ ago. The age difference to the ${ }^{14} \mathrm{C}$ date below the aeolian deposits is probably the result of wood being taken for the ${ }^{14} \mathrm{C}$ analysis rather than seeds or leaves, resulting in an overestimation of the age (Mook and Streurman, 1983; Törnqvist et al., 1992). Other explanations are differential compaction and the slow peat growth rate during this period, which was limited to a few decimetres per thousand years (Makaske et al., 2015). At the final section in Kappersbult (Figure 2.8) the channel deposits are located along the northeastern palaeovalley side. Overbank deposits at this site contain abundant ferruginous concretions (Table 2.3). 
sw

NE

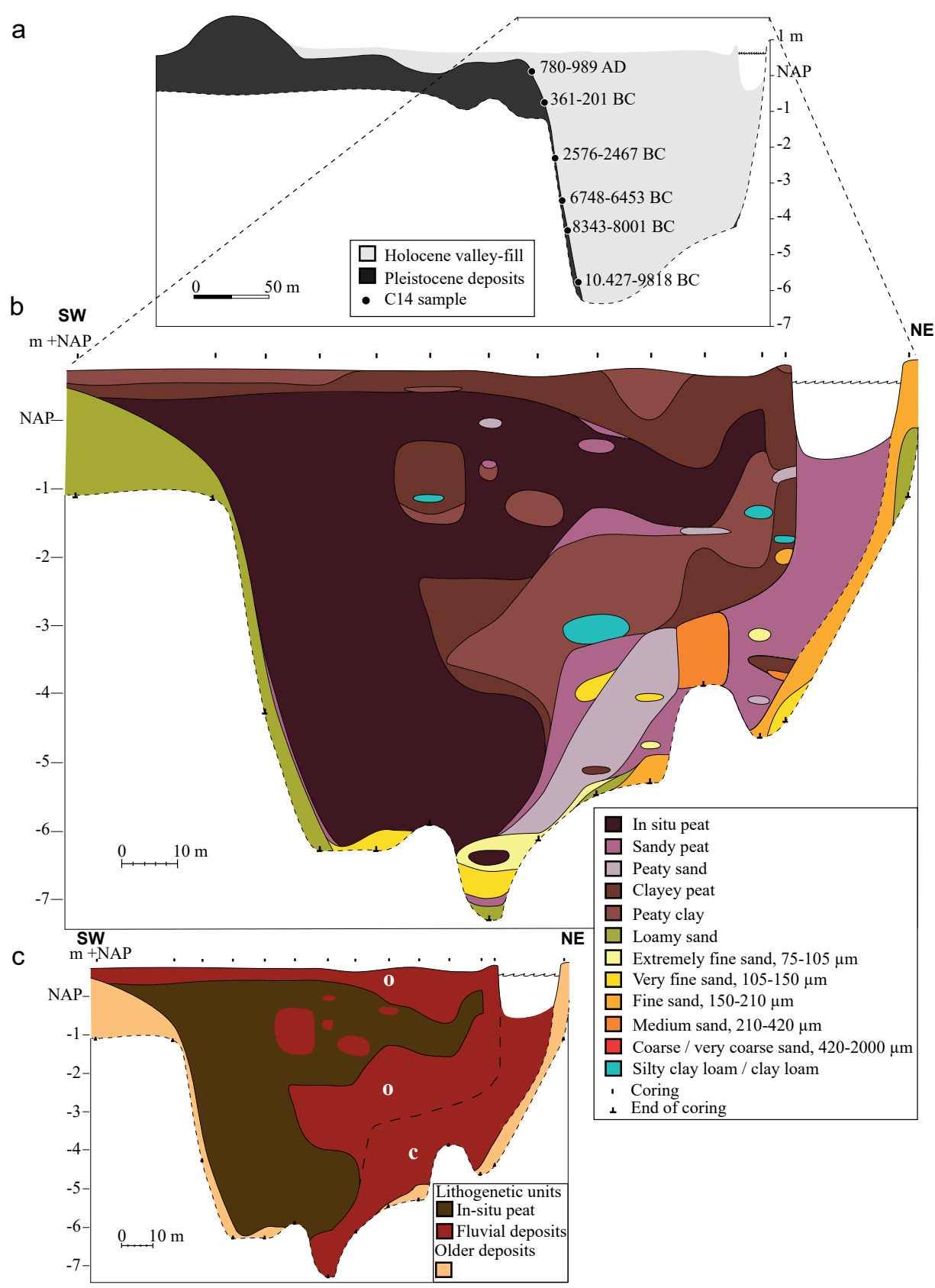

Figure 2.8 Kappersbult: a) Geological cross-section of the valley (modified after Makaske et al., 2015), b) lithological cross-section of the valley fill, c) lithogenetic cross-section of the valley fill. Letter O indicates overbank deposits. Letter $\mathrm{C}$ indicates channel deposits. Actual channel depth is an estimation of the average channel depth. 


\subsection{Conceptual model}

\subsubsection{Stream evolution as a function of valley shape}

Until the start of the Bølling-Allerød interstadial ( $-14.7 \mathrm{ka})$, peat formation was absent and stream channels were situated on the sandy Pleistocene valley floor. As a result of permafrost conditions in the catchment (De Gans, 1981), streams were likely able to laterally migrate as stream power allowed for lateral erosion of the relatively easily erodible, sandy banks. At a later stage, peat started to form as a result of wetter conditions in the valley (Makaske et al., 2015). The oldest ${ }^{14} \mathrm{C}$ date in Kappersbult (KIA_43754, Table 2.2) dates from the Younger Dryas $(-12 \mathrm{ka})$. However, since the ${ }^{14} \mathrm{C}$ date was taken approximately $25 \mathrm{~cm}$ above the valley floor, the initial establishment of peat is expected to date from the Bølling-Allerød interstadial (14.7 - $12.7 \mathrm{ka})$ when warmer and wetter conditions favoured peat growth (Hoek, 2008).

The peat growth has resulted in changing stream morphodynamics, in a way that depends on the position of the channel in the valley. Here we distinguish between disconnected channels and connected channels. The former are located in the central valley and have peat banks on both sides, while the latter are located at the margin of the floodplain, with a peat bank on the inside and sandy bank on the outside.

Disconnected channel reaches, i.e. those in the centre of the valley, aggrade vertically in response to peat growth. Erosion-resistant peat banks (Micheli and Kirchner, 2002a, b; Gradziński et al., 2003; Nanson, 2010; Stenberg et al., 2015) are present on both sides of the channel during aggradation, preventing lateral channel migration (Figure 2.9a-1). This process can for example be seen in the Loon cross-section (Figure 2.4). Although the channel bed lithology changed during the aggradation, the current stream reach location is vertically in line with the stream reach location at the start of peat growth.

Connected channels, i.e. those touching the valley side, aggrade obliquely along the valley side during the accumulation of peat in the valley (Figure 2.9a-2). Rajchl and Uličný (2005, p.607) used the term oblique aggradation in their work and defined it as "a combination of lateral migration and aggradation during channel activity, resulting in stacking of channel-fill bodies oblique to general stratification". Their explanation for oblique aggradation was related to compactional tilting of the underlying peat during the late Oligocene-early Miocene. The underlying cause of oblique aggradation in our study seems related to the differences in resistance to erosion between the peat and the sandy subsurface, with peat having a higher resistance (Micheli and Kirchner, 2002a, b; Stenberg et al., 2015). Due to this difference, channel widening will tend to occur 
at the sandy valley side. On the other side of the stream, fluvial deposits and vegetation will narrow the channel and deposits will be covered by peat during the aggradation of the valley. The combined effect of these two processes is that the channel is pulled to the valley side. However, the erosion rates seem to be low, resulting in a largely unaffected, relatively symmetrical and uniform shape of the subsurface. Another factor that may affect the adherence of the stream channel to the valley side is groundwater seepage from the higher grounds into the valley (Makaske et al., 2015). The occurrence of seepage and the presence of a sandy substrate are not fully independent. Groundwater seepage can occur in the valley, because the sandy valley side is conductive compared to the underlying tills. Some studies have shown that seepage is an important factor in bank erosion, resulting in unstable banks which can initiate and promote lateral channel migration (Fox et al., 2007; Van Balen et al., 2008; Fox et al., 2010; Eekhout et al., 2013). Seepage does not initiate meandering in the Drentsche Aa, but it may enhance the process of oblique aggradation by lowering the resistance to erosion of the valley side. In settings with raised peat bogs the relief may be a third factor. Here, discharge will be concentrated at topographic lows at the margins of the convex bogs, and streams will aggrade obliquely when the bog expands (Ingram and Gore, 1983, p.132). However, this setting differs from the Drentsche Aa where peat growth is groundwatercontrolled (Makaske et al., 2015), also shown by the presence of siderite and iron oxides at the section Kappersbult (Curtis, 1986). Therefore, our setting lacks the convex shape typical for raised bogs, and surface relief is expected to play a minor role in the oblique aggradation process that we document.

The process of oblique aggradation can be seen in the Gasteren1, Gasteren2, Schipborg and Kappersbult cross-sections (Figures 2.5 to 2.8, respectively). Although Schipborg differs from these other sections, because sand banks seem to have been present on both sides of the stream (Figure 2.7a), oblique aggradation also occurred here. Before driftsand was deposited $(2.4 \mathrm{ka})$ peat had a thickness of 6 to $7 \mathrm{~m}$, reaching the current surface level, comparable to the cross-sections at Kappersbult and Loon where ${ }^{14} \mathrm{C}$ datings are present (Table 2.2). Channel deposits were located along the northeastern palaeovalley side. When the drift-sand was deposited, the peat was compacted 3 to $4 \mathrm{~m}$ by the weight of the deposits, but this occurred after the oblique aggradation had taken place. 


\section{Chapter 2}

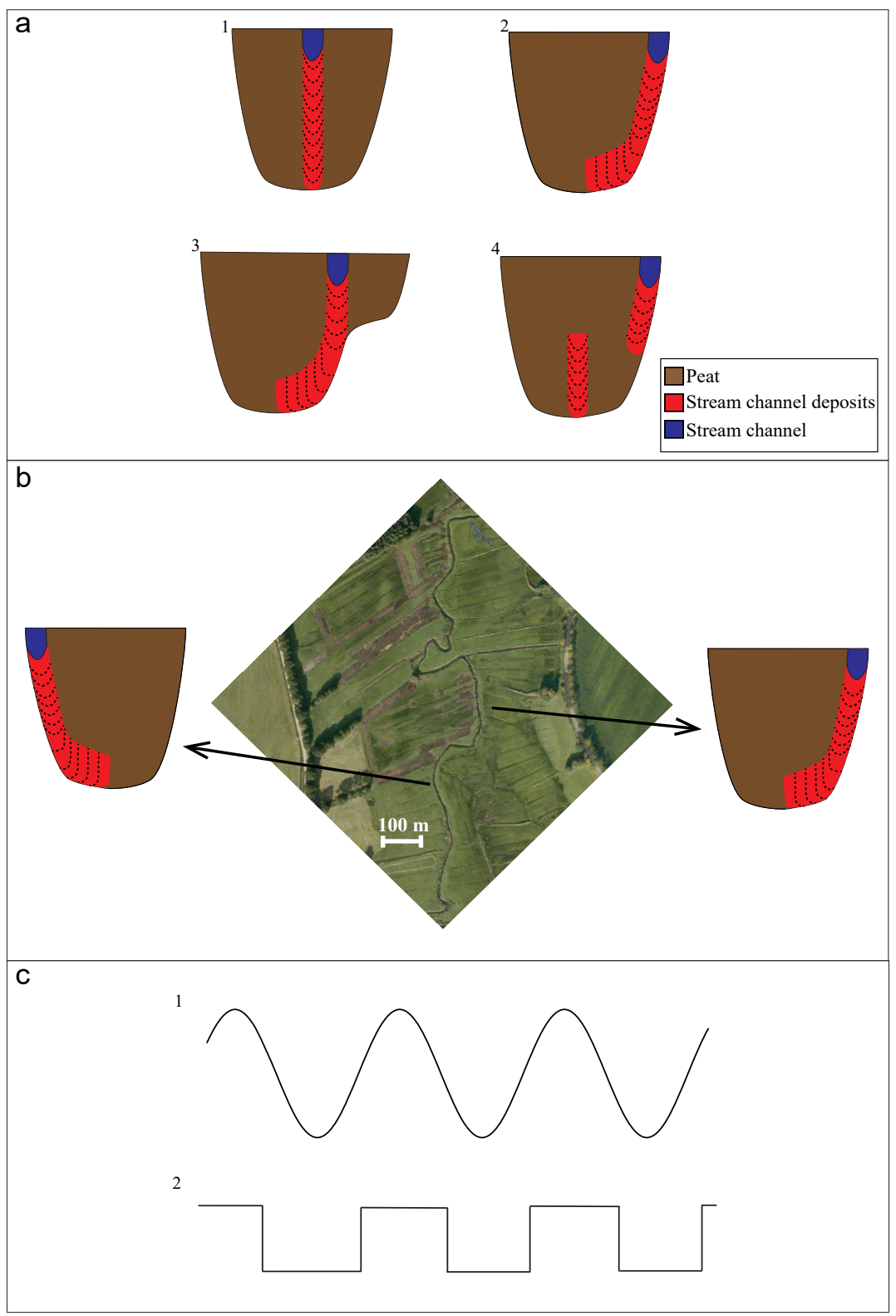

Figure 2.9 Conceptual model of oblique aggradation in a peat-filled valley, resulting in the rectangular, sinuous planform. a) Simplified, schematic cross-sections illustrating different processes that affect the channel planform and morphology in a Holocene valley filled up with peat. 1) An aggrading disconnected channel, 2) a connected channel obliquely aggrading along the valley side, 3 ) a connected channel changing to a discon- nected channel because it overtops the valley, 4) a disconnected channel changing to a connected channel as the result of an avulsion. b) A sketch of the sinuous planform formation by oblique aggradation. c) A sketch of 1) a sinuous planform as a result of lateral migration, 2) a rectangular sinuous planform as a result of oblique aggradation. 
The development of peat is closely associated to the groundwater level (Clymo, 1991). As aggradation continues during the Holocene, the groundwater level can rise above the valley sides. As a result, the peat can overtop the subsurface topography and lie on top of the valley sides. If peat overtops the valley, this may cause streams to disconnect from the valley side and continue to aggrade vertically rather than obliquely. This situation is shown in Figure 2.9a-3, and may explain the transition from oblique to vertical aggradation shown for Gasteren 1 and Schipborg (Figures 2.5 and 2.7). The contrary transition does also occur. A disconnected aggrading channel can become connected to the valley side due to an avulsion and aggrade obliquely from then on. This is shown in Figure 2.9a-4, and may explain the transition from vertical to oblique aggradation for Gasteren2 (Figure 2.6c).

There are several conditions facilitating oblique aggradation. We expect the process of oblique aggradation to be a function of the valley side slope and rate of peat development. Oblique aggradation is possible if the valley side is not sufficiently stabilized by peat prior to exposure to flowing water of the stream. For example, if the valley side slope would be very gentle, the stream can become disconnected from the valley side, since peat can grow on both sides of the stream. A high peat growth rate might enhance the stream becoming disconnected. However, from our data it is impossible to define thresholds for the valley side slope and peat growth rate for oblique aggradation to occur. Oblique aggradation occurred over a wide range of valley side slopes of 3 to 28 degrees. Moreover, the peat growth rates and therefore the aggradation rates changed with time in the Drentsche Aa valley (Makaske et al., 2015), but did not seem to affect the oblique aggradation.

\subsubsection{Effects on stream planform}

Applying the previously described mechanisms to the channel planform shows that the sinuous planform is partly inherited from the period before peat started to grow and fixed the channel reaches. In addition, the sinuous stream planform is partly the result of the combined processes of vertical and oblique aggradation, alternately pulling the stream reaches to the one or the other, opposed valley side (Figure 2.9b). Moreover, the floodplain of the stream widens as a result of peat growth in a V-shaped valley. Adherence of stream reaches to the valley sides, in combination with floodplain widening, results in a stream that is stretched out resulting in increased sinuosity. Our conceptual model shows that the palaeovalley shape is essential for the formation of the current stream planform and floodplain. The palaeovalley shape controls how much the stream planform is stretched out in case of a connected stream, controls whether a stream can become disconnected as a result of peat growth on top of the valley side, and controls the width of the floodplain. The stretching occurred mainly in the first period of the 
aggradation, when the stream is still connected to the valley side. The process will stop if the peat overtops the valley sides, because the stream cannot be connected anymore from that point onwards. The stretching of the stream results in a very distinctive and unique planform, with rectangular bends and relatively straight reaches that either follow the palaeovalley sides, or cross the palaeovalley. Such planforms are present along the entire length of the Drentsche Aa (Figures 2.1 and 2.2). This planform is characteristic for the oblique aggradation process, and different from more circular bends in sinuous planforms that are the result of the process of lateral migration of meandering rivers (Lobeck, 1939; Leopold and Wolman, 1960). Figure 2.9c schematically illustrates both planforms.

In Gasteren1 (Figure 2.5) an abandoned channel is located parallel to the current channel. The abandoned channel can also be seen on the DEM showing a channelshaped low at this location (Figure 2.2c). The abandoned channel can be interpreted as an old tributary, by tracing back the upstream channel reaches on the DEM. The DEM reveals several other inactive channels located parallel to the current active channel within the Drentsche Aa valley. However, these are not defined as elements of an anastomosing stream system (Makaske, 2001), as for instance in the Narew River in Poland where channels are interconnected (Gradziński et al., 2003). From the DEM it can be derived that these parallel channels are former tributaries that run parallel to the main channel for some distance, separated by erosion-resistant peat in between both channels. Nonetheless, some tributary channels enabled avulsions affecting the connectivity of the stream to the valley side, as well as the stream planform (Figure 2.9a-4). The occurrence of avulsions can be derived from the cross-sections at Gasteren (Figures 2.5 and 2.6). An avulsion between Gasteren1 and Gasteren2 led to a shift of the main channel in the centre of the valley to the northeastern valley side by annexation of the lower reach of the tributary. However, the avulsion frequency is probably low, because of the low amount of tributary channels present inthe Drentsche Aa valley. Our findings are in line with Gradziński et al. (2003), who also found that avulsions are infrequent processes in peatlands. 


\subsection{Discussion}

\subsubsection{Landscape evolution in low-energy streams}

Although the conceptual model of oblique aggradation presented here is based on data from the Drentsche Aa, we expect it to be applicable to the morphological development of other streams in similar settings. For example, the distinctive planform with rectangular bends and straight stretches (Figure 2.9c) can be used to identify streams where oblique aggradation may be a dominant mechanism in stream valley reaches with a dominantly organic subsoil. Similar planform characteristics were found for some channel reaches of the anastomosing Narew River in Poland (Figure 2.10a). Gradziński et al. (2003) found that peat growth started here at some locations in the Middle Holocene, reaching thicknesses up to $4 \mathrm{~m}$ on top of a glacio-fluvial sandy subsurface. They also found that most channel reaches have a low sinuosity, typical for anastomosing rivers (Makaske, 2001). However, Gradziński et al. (2003) were not able to explain the presence of channel reaches with a high sinuosity. They also found that these channel reaches are lacking point bars and have not changed planform or position for over 100 years, as appears from comparison with historical maps of 1886 . Our conceptual model may explain the typical planform of the Narew River. Because peat aggraded above the palaeovalley margins, the underlying palaeovalley structures guiding the oblique aggradation mechanism cannot be recognized nowadays and the surface topography is flat.

An exploratory inventory based on satellite imagery (Google Earth) of remote peatland areas with minimal human disturbance provided several other examples of streams with the distinctive rectangular planform, similar to that found in the Drentsche Aa. Examples include streams in vast peatland areas in Siberia, Canada, and Indonesia where peat has grown for the past millennia (Botch et al., 1995; Page et al., 1999; Bridgham et al., 2006; Dyke and Sladen, 2010; Vermeulen et al., 2014) (Figure 2.10b-d). The planforms of these streams differ from more rounded planforms of alluvial meandering streams, e.g. de Roer in The Netherlands (Figure 2.10e) (Wilde and Tanzer, 1965). Although palaeohydrological information on the identified streams in peatlands is lacking, we suggest that it is highly likely that oblique aggradation caused the planform formation, similar to the Narew River.

We propose that our conceptual model of oblique aggradation is applicable when certain preconditions are present. First, an aggrading setting is needed, which is often associated with peat growth. Peat forms as a result of permanently high groundwater levels. Controlling factors of peat growth are climate change and base level rise. Both may result in rising regional groundwater levels. A second precondition is relief. Without relief, streams will be disconnected and oblique aggradation cannot occur. Thirdly, the 
valley side should have a lower erodibility than the valley fill. If both banks are equally erodible, connected streams will not adhere to the valley side and oblique aggradation will not occur. Taking these preconditions into account, oblique aggradation can also occur in different stream settings than presented in this study, explaining the sinuous planform. For instance, a detailed sedimentological study by Makaske et al. (2002, p. 1054) revealed oblique aggradation in the upper Columbia River. In this case, the oblique aggradation was not related to peat growth, but rather the result of one bank being more erodible than the opposed bank during aggradation of the system. This example corroborates that oblique aggradation is a consequence of differences in erosionresistance of opposing banks. Therefore, oblique aggradation can also occur in aggrading stream valleys with a clayey valley fill that also has a relatively high resistance to erosion (Grissinger, 1982; Thorne, 1982). Obliquely aggrading rivers with a clayey bank were also observed by Berendsen and Stouthamer (2000). They found that the meandering rivers Rhine and Meuse between approximately 6000-2500 BP tended to adhere to the sandy edges of the Late Weichselian palaeovalley rather than the central valley, which contains many clay and peat layers. However, the sinuous planform of these rivers is formed by meandering, since a higher stream power results in the ability of a river to meander in spite of erosion-resistant banks (Kleinhans and Van den Berg, 2011). Therefore, oblique aggradation is expected to have a larger impact on the planform of low-energy rivers than on the planform of high-energy rivers.

In different stream settings, the Stable-Bed-Aggrading-Banks model by Brown and Keough (1992) and Brown et al. (1994) might explain the presence of a sinuous planform in laterally stable streams. This model shows that sinuous stream planforms can be inherited from past fluvial regimes when the stream had enough stream power to form a sinuous planform. However, where oblique aggradation results in an increase of sinuosity with time, the stable-bed-aggrading-bank model results in preservation of sinuosity. 


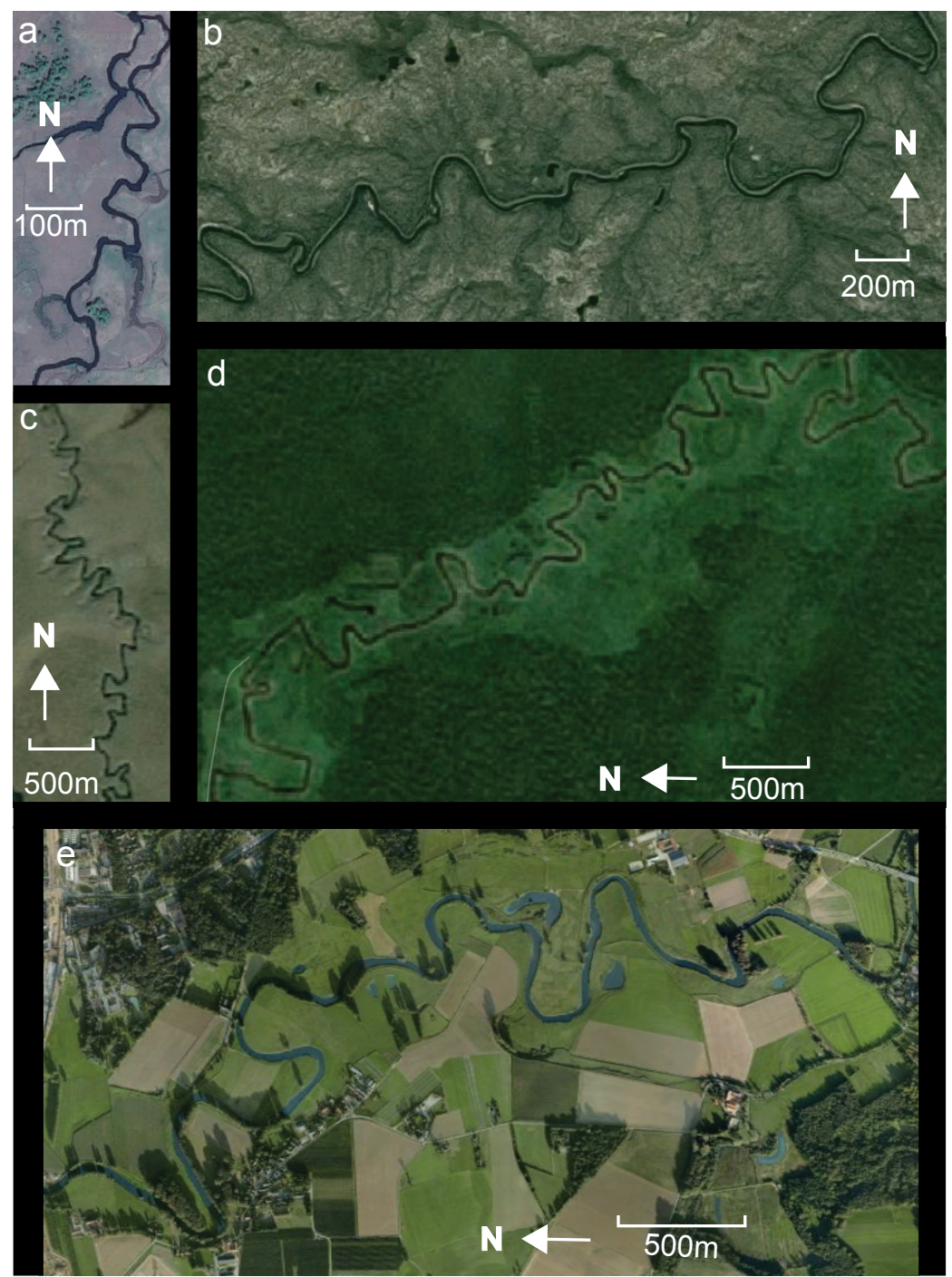

Figure 2.10 Stream planforms throughout the world. a) The Narew River in Poland $\left(53^{\circ} 06^{\prime} 17.9^{\prime \prime} \mathrm{N}\right.$ $\left.22^{\circ} 48^{\prime} 33.7^{\prime \prime E}\right)$; b) a stream draining in the Hudson Bay near Churchill (58 $\left.16^{\prime} 09.8^{\prime \prime} \mathrm{N} 95^{\circ} 43^{\prime} 18.4^{\prime \prime W}\right)$; c) a stream near Taman National Park in Indonesia ( $\left.1^{\circ} 03^{\prime} 05.7^{\prime \prime} \mathrm{N} 112^{\circ} 21^{\prime} 44.5^{\prime \prime} \mathrm{E}\right)$; d) a tributary of Uele in Siberia $\left(72^{\circ} 32^{\prime} 24.3^{\prime \prime N} 118^{\circ} 04^{\prime} 23.0^{\prime \prime E}\right)$; e) the Roer in The Netherlands $\left.51^{\circ} 9^{\prime} 42.80^{\prime \prime} \mathrm{N} 6^{\circ} 0^{\prime} 1.43^{\prime \prime} \mathrm{E}\right)$. Source: Google Earth, 2016 


\subsubsection{Lessons for stream restoration}

The palaeohydrological context of streams provides valuable information for water managers to identify realistic stream restoration goals. Currently, stream restoration often fails, due to the lack of a scientific context (Wohl et al., 2005) and stream restoration practices (e.g. stream re-meandering) are often implemented without having set clear goals or states of success (McMillan and Vidon, 2014). It has been argued that reference states should not be used as a goal in stream restoration projects, since streams are dynamic and change with time so previous states may be impossible to return to (Dufour and Piégay, 2009). Instead, it has been argued that we should learn from the processes that result in stream dynamics and account for these processes in the restored stream (Kondolf, 2006; Brierley and Fryirs, 2009; Brierley and Fryirs, 2015). Makaske and Maas (2015) suggested to design new stream channels based on calculations of the hydraulic and planform geometry that fit the current stream power rather than copying these aspects from historical maps. However, the planform of a peatland stream such as the Drentsche Aa has changed little over the last thousands of years and has little relation to the hydrology of the system and limited changes thereof. Therefore historical maps provide excellent input to design the stream planform in peatland streams.

Some stream restoration projects in peatlands involve restoring dispersed wetland systems rather than re-designing the stream channel. An example of a historic dispersed wetland system, or "swampy meadow" (Mactaggart et al., 2008), was found in southeast Australia. Here the dispersed wetland system was incised by a stream following human colonization and land use changes (Prosser et al., 1994; Nanson, 2009). For the Drentsche Aa system, we found no evidence of a wetland without a channel. In contrast, all stratigraphic cross-sections show evidence of channel deposits at all stratigraphic levels, although we are aware that stratigraphic layers without a channel might have existed and been incised by a channel at a later stage. From our data and a previous study (Makaske et al., 2015) there are no indications of specific incisional phases, although again minor phases of incision or denudation cannot be excluded. This finding contrasts with previous ideas of natural streams in similar lowland settings. Broothaerts et al. (2013) and Lespez et al. (2015) related the presence of peat in valley systems to dispersed wetland systems. Our study shows that stream channels can be identified within peat, but that such differentiation requires a very dense core spacing combined with detailed lithogenetic identification. We propose that dispersed wetland systems are not the natural state of low-energy stream valleys such as the Drentsche Aa, although we cannot rule out that dispersed wetland systems existed in the upper branches of the stream system, where the stream power is too low to actually form a channel. 


\subsection{Conclusions}

We identify oblique aggradation as a key process leading to highly sinuous planforms in peat-filled valley systems. Oblique aggradation may occur in aggradational settings where the valley side consists of material that is more easily erodible than the (organic) valley fill. The stream gets literally stretched out with time due to a combination of floodplain widening and stream reaches aggrading obliquely along opposed valley sides. This novel conceptual model for stream evolution may explain rectangular, sinuous planforms observed for other peatland systems from satellite imagery, and may also be applicable to other settings where opposed banks have differences in erosion resistance. Our explanation of the sinuosity of low-energy streams in the absence of lateral migration supports water managers in stream channel design in the context of stream restoration projects.

\section{Acknowledgements}

The authors would like to thank the following fellow fieldworkers for their help: Jos Candel, Bas Nabers and Foeke Menting. This chapter has benefited greatly from reviews by Kim Cohen and one anonymous reviewer. Bertil van Os is thanked for his help with the XRF-analysis. Erna Voskuilen, Benny Guralnik, Alice Versendaal and Maud van Soest are thanked for their help with the OSL analysis. Waterschap Hunze \& Aa and Staatsbosbeheer are thanked for access to and inside knowledge of the study area. Philip Wenting is thanked for his help with the GNSS and GPR. Gilbert Maas, Ype van der Velde and Jelmer Nijp are thanked for the open discussions on the concepts. 


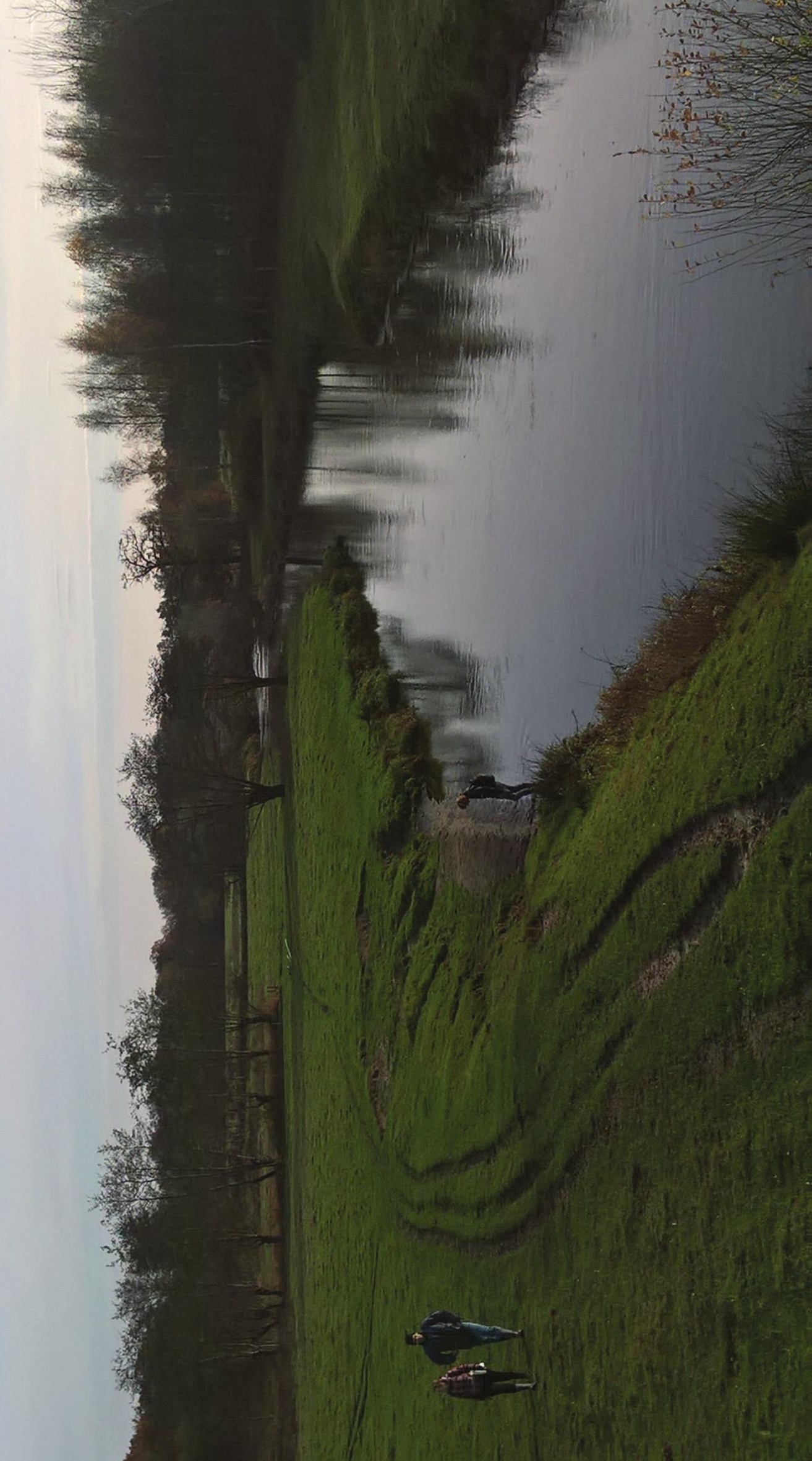




\section{Chapter 3}

Self-constraining of low-energy

meandering rivers; a novel explanation for tortuous planforms and low mobility 


\title{
Chapter 3
}

\begin{abstract}
Meandering rivers are abundantly present on Earth, from the largest rivers to the smallest tributaries. The classical view of meandering rivers is a sinuous planform with rounded bends, which grow and migrate until they are cut off. However, many low-energy meandering rivers have planforms that are much more complex than this classical view due to the heterogeneity of their alluvium, and show relatively limited channel migration. Based on a detailed palaeogeographic study, we infer that low-energy meandering rivers may develop tortuous planforms with sharp bends, while their self-formed deposits increasingly constrain the channel mobility. This mechanism is corroborated by data from 47 meandering river reaches of varied scale from around the world, which show that erosion-resistant floodplain deposits are preserved in the river banks when the river energy is below a critical threshold. We propose the term 'self-constraining' for low-energy rivers where increase in bank stability with time results in more tortuous planforms and reduced mobility. A conceptual model, based on the dataset, shows that the increase in bank stability with time also enlarges the required energy needed to break out of the self-constraining tendency. Self-constraining thereby enhances resilience of the system for bank erosion, but unexpected increase in bank erosion may occur if river energy exceeds the critical threshold. Our study provides a novel explanation for lowenergy river planforms and dynamics, and new insights on their responses to climatic changes.
\end{abstract}

Submitted manuscript: Candel, J. H. J., B. Makaske, N. Kijm, M. Kleinhans, J. E. A. Storms, and J. Wallinga, in review. Self-constraining of low-energy meandering rivers; a novel explanation for tortuous planforms and low mobility: The Depositional Record. 


\subsection{Introduction}

Meander bend formation has been extensively studied by earth scientists, hydrologists and engineers (e.g. Friedkin, 1945; Leopold and Wolman, 1957; Ikeda and Parker, 1989; Stølum, 1996; Seminara, 2006; Camporeale et al., 2007; Gibling and Davies, 2012; Lazarus and Constantine, 2013). Widely accepted is the concept that river bends form due to instability between the flow and bed, amplified by bend flow (Struiksma et al., 1985; Ikeda and Parker, 1989; Seminara, 2006). This classical model forms the basis of both physical and numerical river meander migration models, which produce simulations of freely meandering patterns with rounded bends and continuous lateral migration (Crosato, 2009; Kleinhans, 2010; Motta et al., 2012b). However, natural meandering rivers have a wide range of planform complexities (Figure 3.1), and not all rivers with sinuous planforms show lateral migration (Hickin and Nanson, 1984; Güneralp and Rhoads, 2011; Kleinhans and Van den Berg, 2011; Vermeulen et al., 2014; Candel et al., 2017).

The term "tortuosity" was introduced by Schumm (1963), and used to refer to rivers with complex planforms consisting of unusually sharp bends with variable size and abrupt, irregular changes in channel direction, lacking the typical smoothness of ideal meander curves (Figure 3.1a-d). We adopt this definition of tortuosity here, and emphasize that it is radically different from the use of tortuosity as a synonym for sinuosity by some others (e.g. Frascati and Lanzoni, 2009). Sharp bends are commonly defined as $\frac{R_{c u r v}}{w}<2.0\left(R_{\text {curv }}\right.$ = bend curvature, $w=$ channel width), and form when outer banks are relatively erosionresistant compared to the river stream power (Leeder and Bridges, 1975; Ferguson et al., 2003; Makaske and Weerts, 2005). Field measurements by Schumm (1963) showed that greater river tortuosity relates to larger silt-plus-clay (SC) fractions of river banks. Subsequent research indicated that large SC-fractions are typically found in low-energy meandering rivers (Nanson and Croke, 1992). More recently, numerical modelling studies showed that tortuous planforms develop when heterogeneous floodplains are included in the simulations, consisting of depositional units with different resistances to erosion (Camporeale et al., 2005; Güneralp and Rhoads, 2011; Motta et al., 2012a; Bogoni et al., 2017). These authors stress that floodplain heterogeneity is an important control on planform complexity in (simulated) meandering rivers. Additionally, Hudson and Kesel (2000), who compared sections of different floodplain heterogeneity in the Mississippi river, found that average lateral migration rates are lowest where floodplain heterogeneity is highest. The authors explain this by greater presence of cohesive (silty and clayey) and organic-rich deposits (e.g. clay plugs), which can be 10 to 20 times more erosion-resistant than non-cohesive (sandy) units (Hjulstrom, 1935). 


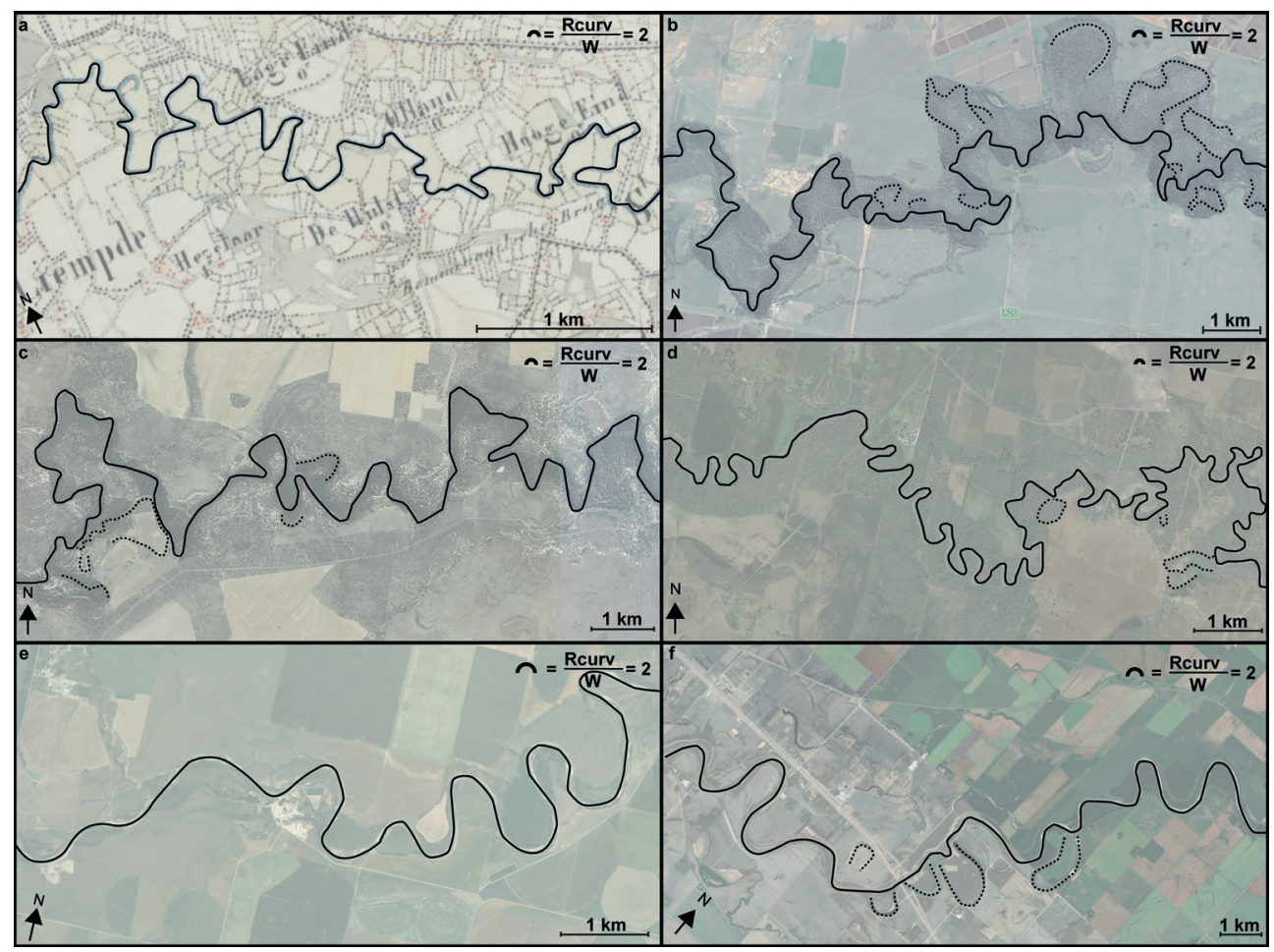

Figure 3.1 River planforms throughout the world, a-d showing tortuous meandering planforms, and e-f showing relatively classical meandering planforms, derived from Google Earth satellite imagery (2018) for b-f. All planforms are scaled to five predicted meander amplitudes (Carlston, 1965). a) Dommel River in The Netherlands before the channelization, the planform was derived from the Topographical Military Map (TMK) dating from $1837 \mathrm{CE}$ (Van der Linden, 1973) (51³4’12.3”N 524’43.6”E); b) Murrumbidgee River

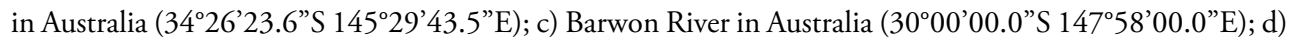

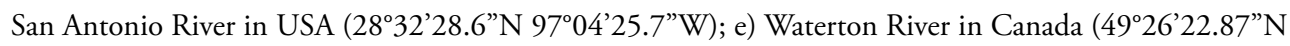
$113^{\circ} 27^{\prime} 33.36^{\prime \prime W)}$ f) Assiniboine River in Canada (4958'20.82”N 98 7’20.61”W).

Based on this published information, we hypothesize that low-energy meandering rivers in heterogeneous floodplains predominantly erode the easily erodible, noncohesive depositional units (Turnbull et al., 1966; Hickin and Nanson, 1984), while they continuously form both easily erodible (e.g. point-bar) and relatively erosionresistant (e.g. channel-fill) depositional units (Smith et al., 2009; Bogoni et al., 2017). This mechanism may explain why low-energy meandering rivers tend to have tortuous planforms with low channel mobility. We aim to test this hypothesis of a relation between inhibited lateral channel mobility, planform tortuosity and the evolution of floodplain sediment composition by a detailed reconstruction of long-term evolution of a low-energy meandering river. Additionally, we aim to define the limits of river energy and bank erosion-resistance at which planforms become tortuous and laterally constrained by comparing these characteristics for a large dataset of meandering rivers 
for which data on stream power, river energy (i.e. stream power), bed material, and SCfractions of the banks are available.

\subsection{Materials and Methods}

\subsubsection{Study area}

We studied the Holocene planform evolution and floodplain stratigraphy of the Dommel River (Figure 3.2); a low-energy meandering sand-bed river with a tortuous planform. This investigation combined coring, ground-penetrating radar (GPR) and geochronological analysis around four oxbow bend complexes. The Dommel River's source is located at the Kempen Plateau in Belgium, $+77 \mathrm{~m}$ NAP (Dutch Ordnance Datum, $\approx$ sea level), and drains into the much larger river Meuse at $+2 \mathrm{~m}$ NAP (Figure 3.2). It has a length of $120 \mathrm{~km}$ of which $85 \mathrm{~km}$ is located in The Netherlands. The catchment size is ca. $677 \mathrm{~km}^{2}$. The river has an annual average discharge of $14 \mathrm{~m}^{3} \mathrm{~s}^{-1}$ and a mean annual flood discharge of $22.3 \mathrm{~m}^{3} \mathrm{~s}^{-1}$ at its downstream end.

The Dommel River was a braiding river during the Pleniglacial with abundant sediment availability, and low average discharges and transport capacity (Vandenberghe and Bohncke, 1985; Vandenberghe and Van Huissteden, 1988). The cold and dry climatic conditions and absence of vegetation during the Pleniglacial resulted in large-scale deposition of coversand of 0.5 to $2 \mathrm{~m}$ thick in the study area, which currently overlies all older deposits outside the valley (Van der Hammen, 1971; Vandenberghe and Bohncke, 1985). Locally, the coversands are very fine-grained and would more properly be called loess and sandy loess, referred to as 'Brabant loam' or the Liempde Member of the Boxtel Formation (Vink, 1949; Schokker, 2003). The climate changed to warmer and wetter conditions at the transition from Pleniglacial to Late Glacial, and vegetation reestablished. Consequently, the sediment availability decreased and the river discharge increased resulting in a relatively large, incising meandering river (Vandenberghe and Bohncke, 1985; Vandenberghe and Van Huissteden, 1988; Vandenberghe, 1995). The result of the Late Glacial meandering phase is a well-expressed bluff along the edge of the valley (Figure 3.2c-f).

This research focusses on planform and morphological development of the Dommel River during the relatively warm and wet Holocene. Historical maps show that around 1890 CE the river had a tortuous planform that was hardly affected by humans, except from some local modifications related to weirs and watermills (Waterschap De Dommel, 1941) (Figure 3.1a). After $1890 \mathrm{CE}$, many river bends and bend complexes were cut off to promote rapid drainage of the catchment (Waterschap De Dommel, 1941). 


\section{Chapter 3}

Palynological data for the Dommel valley (Janssen, 1972; Van Leeuwaarden, 1982) are available for the entire Holocene and indicate relatively small-scale human cultivation on the higher grounds around $500 \mathrm{BCE}$, while these areas were increasingly being used for agriculture since $1000 \mathrm{CE}$ with the cultivation of buckwheat, rye and pine. At that time the valley was used largely as pasture. Currently, the land use around the Dommel River is forest and agriculture (cattle and arable farming).

There is little morphological evidence of active channel migration prior to river normalization; some oxbow complexes are present, but no scroll-bar forms are observed (Figure 3.2d-f). The historical map of $1837 \mathrm{CE}$ shows how these bend complexes were still part of the main river (Figure 3.1a). Figure 3.2 shows three selected research sites in the Dommel River, which are selected based on the presence of oxbow lakes. These oxbow lakes are well-preserved in the landscape and consist of sharp bend complexes, similar to Dommel River bends that are still connected to the river (Van Alphen et al., 1984). 

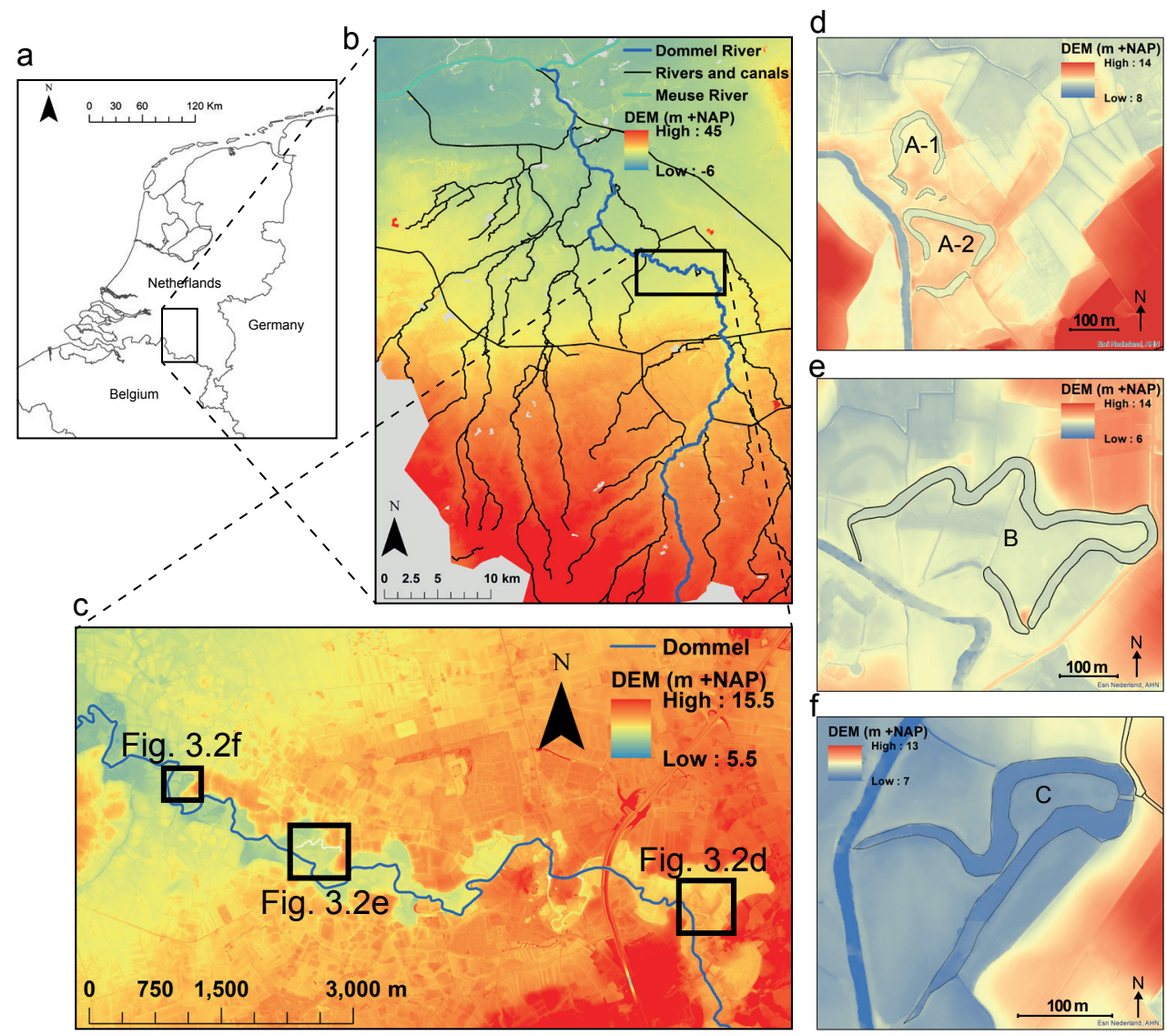

Figure 3.2 Maps of the Dommel River, a) map showing the location of the Dommel River in The Netherlands; b) a digital elevation map (DEM, Actueel Hoogtebestand Nederland, 0.5x0.5 m grid) (Van Heerd and Van't Zand, 1999) of the Dutch section of the Dommel river. All study sites are indicated. c) DEM of the three study locations A,B and C, showing the oxbow bend complexes (d,e,f). 


\subsubsection{Ground-penetrating radar}

GPR was used to select suitable coring locations based on stratigraphic differences, and to support the interpretation of the lithological borehole cross-sections. In a sandy subsurface, lateral accretion surfaces and palaeochannels can usually be detected with a GPR. Loamy and peaty subsurfaces strongly attenuate the GPR signature (Neal, 2004), resulting in poor GPR images and no subsurface structure information. GPR measurements were conducted with a pulseEKKO PRO $250 \mathrm{~Hz}$ with a SmartTow configuration. The GPR was used in different directions relative to the bend complexes (Figure 3.3). For our study area, the electromagnetic-wave velocity was determined to be $0.052 \mathrm{~m} \mathrm{~ns}^{-1}$, derived by using isolated reflector points (Van Heteren et al., 1998; Neal, 2004 ) in the EKKO_Project ${ }^{\mathrm{TM}}$ software, and by comparing depths of recognizable layers with the coring data.

\subsubsection{Coring and Lithology}

Hand corings were performed along the in- and outside of the river bend complexes (Figure 3.3). The surface elevation of each coring site was determined using a GPS combined with the DEM (0.5x0.5 m grid) (Van Heerd and Van't Zand, 1999). A gouge auger $(\varnothing 3 \mathrm{~cm})$ was used when the subsurface consisted of peat or water-saturated loam, an Edelman auger for unsaturated loam or sand and a Van der Staay suction corer (Van de Meene et al., 1979) for saturated sand. In total, 130 corings were performed to a maximum depth of $5.9 \mathrm{~m}$. Lithology of sediment cores was described in 10-cmthick intervals, using the USDA nomenclature (Berendsen and Stouthamer, 2001). The sediment grain size $\left(\mathrm{D}_{50}\right)$ of non-organic, sandy samples was visually checked in the field by comparison with a sand ruler. In addition, we described the plant macro-remains, any visible bedding, colour, and presence of gravel. 
a
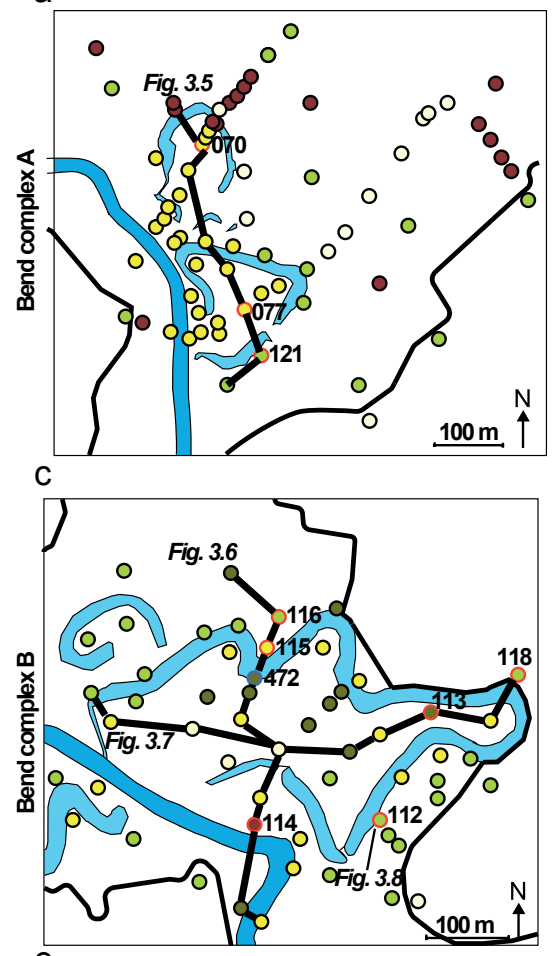

e

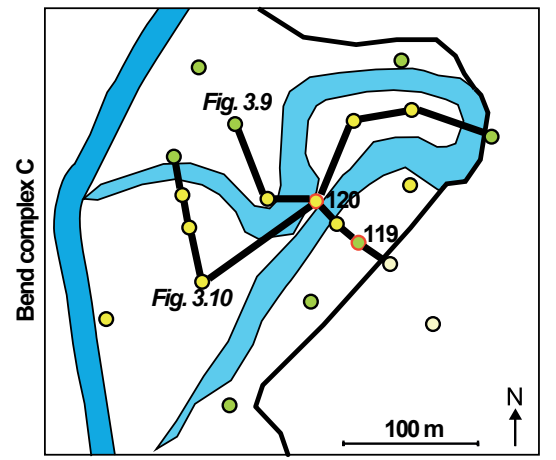

b

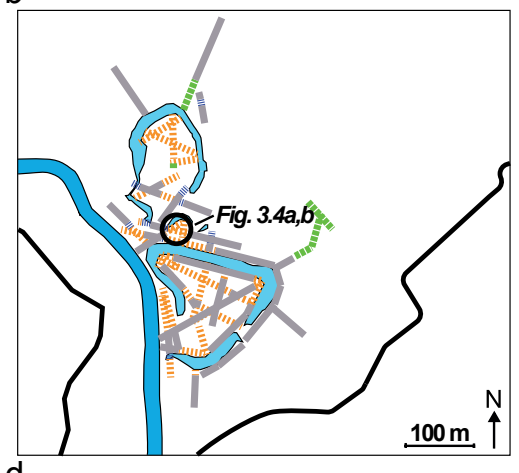

$\mathrm{d}$
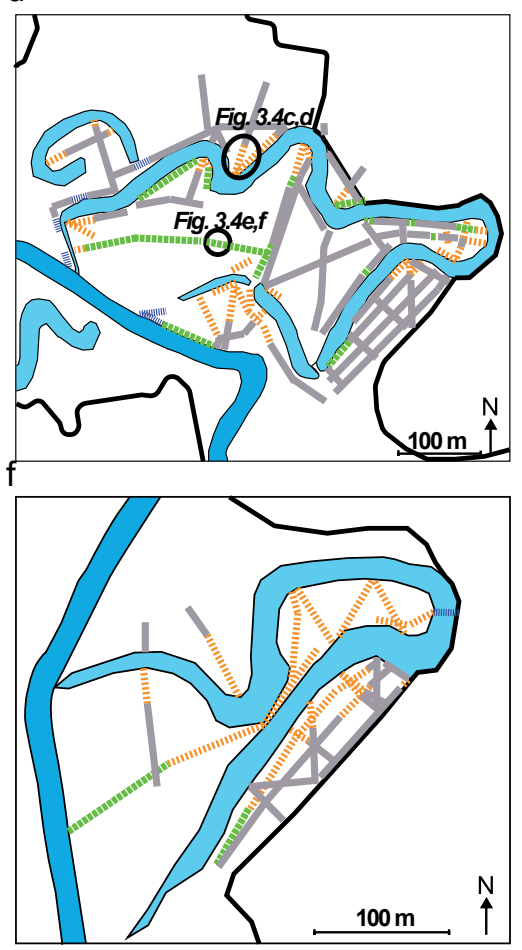

Figure 3.3 Maps of the study locations. a,c,e) Simplified maps showing the coring, dating and transect locations. The colour infill of the coring locations indicate the main lithology that was found. The lines indicate the transects shown in the Figures 3.5 to 3.10. The numbers refer to OSL and ${ }^{14} \mathrm{C}$ sample codes, and indicate the sampling locations (Table 3.1), b,d,f) Simplified maps showing the GPR profile locations; colours denote the observed structures. Some examples are given in Figure 3.4. 
The lithological data are presented in five lithological cross-sections. A lithogenetic interpretation was derived from each cross-section, inferred from the lithological properties, facies geometries and ground-penetrating radar (GPR) data. In addition, we mapped the location of erosion-resistant layers. We defined erosion-resistant layers as peaty or loamy layers with a minimum thickness of $0.5 \mathrm{~m}$.

\subsubsection{OSL Dating}

Eleven samples for quartz optically stimulated luminescence (OSL) dating were taken to determine the age of erosion-resistant layers and point-bar deposits (Figure 3.3). Samples were collected in a PVC tube ( $64 \mathrm{~cm}, 25 \mathrm{~cm}$ length) with a Van der Staay suction corer (Van de Meene et al., 1979; Wallinga and Van der Staay, 1999), allowing collection of non-light-exposed sand in the middle of the tube. The OSL age was determined at the Netherlands Centre for Luminescence dating, Wageningen University. Approximately $150 \mathrm{~g}$ of sediment, from the light-exposed outer ends of the tubes, was used for the dose rate analysis, and the remaining sediment was prepared for equivalent dose estimation.

For dose rate estimation, samples were dried and ashed to remove water and organics and determine their weight fractions. Samples were ground and mixed with wax and moulded in a puck to ensure radon retention and provide a fixed geometry for measurement. Radionuclide concentrations were determined using high-resolution gamma-ray spectroscopy, and converted into infinite matrix dose rates (Guérin et al., 2011). Attenuation by water and organics (Aitken, 1998) were taken into account, based on present water and organic content. Grain size attenuation was taken into account for beta dose rate estimation (Mejdahl, 1979). A contribution of cosmic dose rates was included following Prescott and Hutton (1994), and assuming immediate burial to present depth. A minor contribution from internal alpha irradiation inside the quartz grains (Vandenberghe et al., 2008) was also included.

For equivalent-dose estimation sand-sized grains of quartz $(180-212 \mu \mathrm{m})$ were obtained through sieving and treatment with $\mathrm{HCl}, \mathrm{H}_{2} \mathrm{O}_{2}$ and $\mathrm{HF}$. For each sample, small aliquots (2 $\mathrm{mm}$ diameter, about 75 grains) were prepared on stainless-steel discs sprayed with silicon oil. Measurements were performed on a Risø TL/OSL DA20 reader (Bøtter-Jensen et al., 2003), using the single-aliquot regenerative dose (SAR) protocol (Wintle and Murray, 2006). A relatively low preheat of $200^{\circ} \mathrm{C}$ for 10 s and 10 s 'cutheat' of $180^{\circ} \mathrm{C}$ were used, to prevent thermal transfer effects. Early-background subtraction was used to maximize the contribution from the quartz fast-OSL component (Cunningham and Wallinga, 2010). Around 40 aliquots were measured per sample. The Central Age Model (Galbraith et al., 1999) was used to determine overdispersion for all samples. This model was also used to determine the palaeodose (best-estimate of the burial dose) for the sample of aeolian 
sediment taken from the valley side (NCL-2117118; Table 3.1). The overdispersion not related to heterogeneous bleaching $\left(\sigma_{b}\right)$ was estimated to be $17 \pm 7 \%$ (Cunningham et al., 2011), and used as sigmab input for the bootstrapped version of the Minimum Age Model (Galbraith et al., 1999; Cunningham and Wallinga, 2012), which was used to determine palaeodoses from scattered equivalent dose distributions for all fluvial samples. Burial ages were determined by dividing the palaeodose by the dose rate, taking all uncertainties in both into account. Following conventions, results are reported in ka relative to the year of sampling (2017 CE) with 1-sigma errors (Table 3.1).

\subsection{5 ${ }^{14} \mathrm{C}$ Dating}

A single sample for ${ }^{14} \mathrm{C}$ dating was taken from a residual channel-fill using a gouge auger $(\varnothing 6 \mathrm{~cm})$ (Figure 3.3e). Macro-remains from terrestrial species (e.g. sedge) were selected in the laboratory using a light microscope. Samples were stored in diluted $\mathrm{HCl}$ (4\%) at $5{ }^{\circ} \mathrm{C}$. The ${ }^{14} \mathrm{C}$ age was determined by Accelerator Mass Spectrometry (AMS) at the Centre for Isotope Research (Groningen University). For calibration, the IntCal13 curve was used in the OxCal4.2.4 software (Bronk Ramsey, 2009; Reimer et al., 2013). Following conventions, uncalibrated radiocarbon age (BP) and calibrated calendar age (CE) are reported.

\subsubsection{Comparison to other meandering rivers}

The dataset of Kleinhans and Van den Berg (2011) was used as starting point for our analysis, because we required similar data and selection criteria. The data contained in this dataset are mean annual flood discharge, bankfull discharge, median bed material grain size and valley slope. In addition, we determined the average silt-plus-clay fraction of the river banks and tortuosity of the channel planform (see below). All studied meandering rivers are alluvial rivers that have no sign of strong modification by humans, no engineering in the river, a perennial flow regime, and an effective channel-forming discharge $\left(Q_{\text {eff }}\right)>10 \mathrm{~m}^{3} \mathrm{~s}^{-1}$ (mean annual flood, and when not available the bankfull discharge was taken, see argumentation of choice given by Kleinhans and Van den Berg (2011)). All rivers are laterally connected with their floodplain, and are not strongly incising or aggrading. The dataset of Kleinhans and Van den Berg (2011) sometimes included multiple reaches of the same river for which different values of $Q_{\text {eff }}$ or valley slope $\left(S_{v}\right)$ were found. 

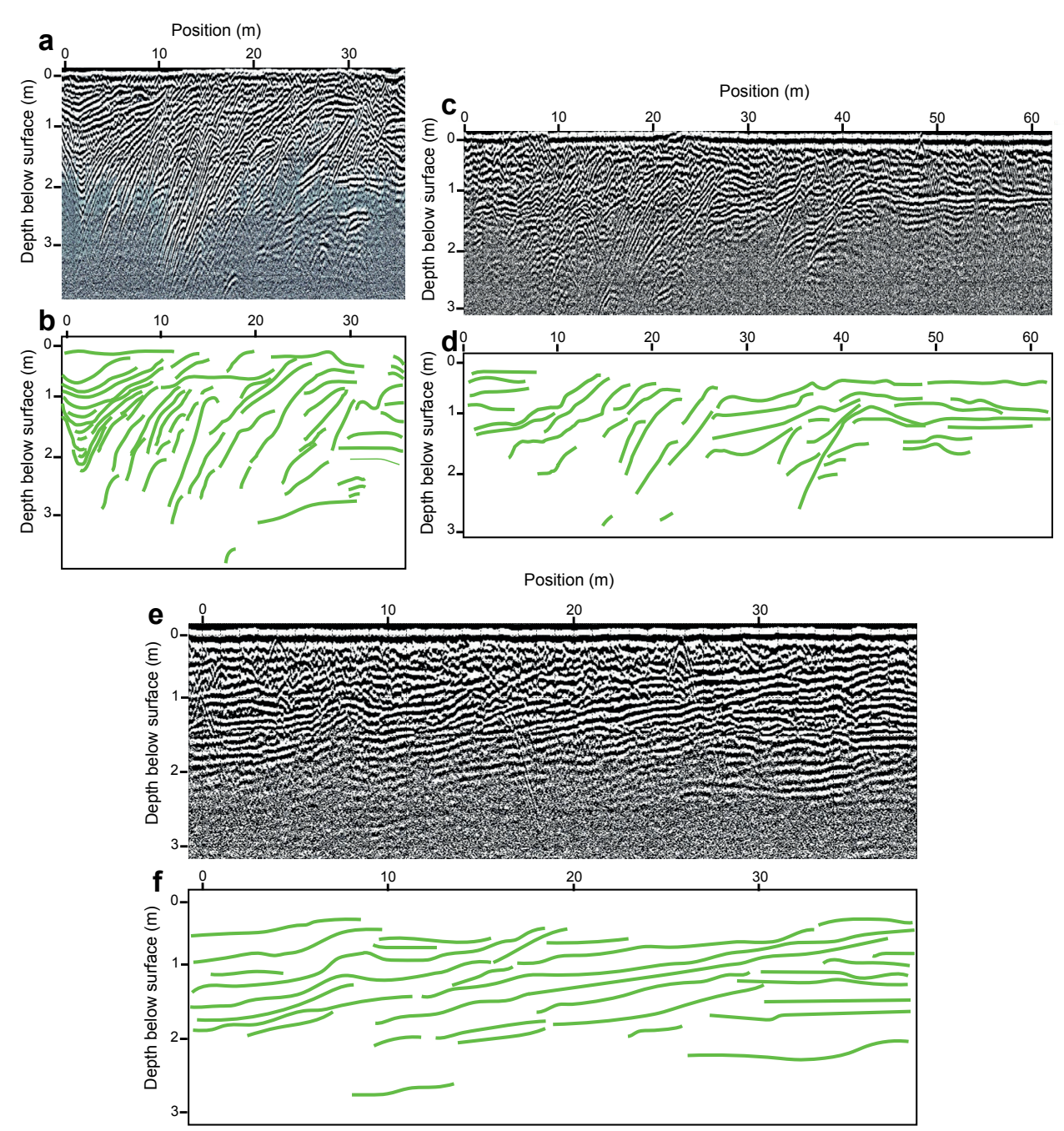

Figure 3.4 GPR transect examples. Locations are shown in Figure 3.3. a,c,e) showing plain GPR data, $\mathrm{b}, \mathrm{d}, \mathrm{f})$ showing interpreted subsurface strata.

From this dataset, a subset of meandering river reaches was selected for which published information on average SC-fractions of the river bank was available in the literature. Estimates on average SC-fractions of the fluvial depositional units are taken as a measure of the erosion-resistance of the floodplain units following Hjulstrom (1935), Schumm (1963) and Julian and Torres (2006), as this is the only suitable parameter that is abundantly available and was previously linked to tortuosity (Schumm, 1963). These river banks represent either depositional units of the river, or the valley side. A high or low average silt-plus-clay fraction of the river banks suggests they consist of relatively erosion-resistant or easily erodible depositional units, respectively. Data were 
not included if SC-fractions were only qualitatively described. Where ranges of SCfractions were reported, we used the middle of the range. Sampling methods and texture analysis varied between studies that reported average SC-fractions; for details we refer to the cited sources in the Appendix 2. Generally, multiple samples were taken of both river banks near the gauging stations, often at several depths from the exposed river bank. Samples were in most cases analysed in the laboratory using the sieving and pipette method.

Kleinhans and Van den Berg (2011) showed that the potential specific stream power $\left(\omega_{p o t}\right.$ is a suitable measure for river energy to explain the degree of meandering. The potential specific stream power was calculated by applying the relation presented by Kleinhans and Van den Berg (2011):

$\omega_{p o t}=\frac{\rho g \sqrt{Q_{e f f}} S_{v}}{\varepsilon}$

where $\omega_{p v}$ is the potential specific stream power $\left(\mathrm{W} \mathrm{m}^{-2}\right), \rho$ is the water density $\left(\mathrm{kg} \mathrm{m}^{-3}\right)$, $\mathrm{g}$ is the gravitational acceleration $\left(\mathrm{m} \mathrm{s}^{-2}\right)$, and coefficient $\varepsilon=4.7 \sqrt{ } \mathrm{s} \mathrm{m}^{-1}$ for sand-bed rivers and $\varepsilon=3.0 \sqrt{ } s m^{-1}$ for gravel-bed rivers (Van den Berg, 1995). A large advantage of the potential specific stream power as a measure for river energy is that it relies on parameters that are independent of the actual channel planform, and hence can be used to explain the planform tortuosity of a river (Van den Berg, 1995).

To the best of our knowledge there is no widely accepted metric to quantify planform tortuosity (ignoring the metric proposed that is based on channel length divided by valley length, and thus reflects sinuosity rather than tortuosity). Here we propose a new metric, based on the fraction of bends that are 'sharp' with a $\frac{R_{\text {curv }}}{w}<2.0\left(R_{\text {curv }}=\right.$ bend curvature, $w=$ channel width). To estimate this metric, bend curvature of the channel centreline and average channel width of each bend were determined using satellite imagery from Google Earth for 20 consecutive meander in the river reaches contained in the Kleinhans and Van den Berg (2011) dataset. Including more bends in this measure would result in sharp bend measurements that are taken too far from the measurements of the other parameters.

We supplemented the resulting dataset with information from the Dommel River (this study), and the Overijsselse Vecht (recently studied by our team (Candel et al., 2018b)). Finally, data for two Late-Glacial rivers were included (Dommel and Niers), based on channel patterns recognizable from DEMs or satellite imagery, and published information on average SC-fraction of the surrounding depositional units (see Appendix 2 for references). The Late-Glacial Dommel River had a bankfull discharge of a factor 
12 to 15 higher than the current Dommel River (Vandenberghe, 2001). Valley slope was estimated using the depths of Late-Glacial deposits from DINOloket, a national geological borehole database (TNO, 2015). Data for the Late-Glacial Niers River was derived from Kasse et al. (2005). Planform tortuosity of Late-Glacial rivers was measured from visible palaeochannels on DEMs or satellite imagery or from the valley side bluffs, divided by the estimated width of the Late-Glacial systems known from Late-Glacial oxbow channels.

\subsection{Results}

\subsubsection{Lithogenetic units}

Lithogenetic units were identified within the Holocene Dommel River valley fill based on lithology, planform, facies architecture (GPR) and interpreted genesis. In general, the Holocene valley fill can be distinguished from bordering Pleistocene valley side deposits and underlying Pleistocene valley-fill deposits by the presence of organic matter (OM), e.g. recognizable plant remains, and dark colours (Bisschops, 1973; Berendsen and Stouthamer, 2000; Huisink, 2000).

The Pleistocene valley-fill deposits consist of very fine to medium fine sand (105 to $420 \mu \mathrm{m}$ ), have a light, bright colour whereas thick beds (several decimetres) of loam or OM are absent (Bisschops, 1973; Schokker and Koster, 2004). Small fining upward sequences of several decimetres can sometimes be recognized in the Pleistocene valley fill. Thin gravel beds up to a decimetre can be found within the unit. The top of the Pleistocene valley fill is usually found at approximately 4 to $5 \mathrm{~m}$ below the surface (Bisschops, 1973).

The Pleistocene valley side can clearly be distinguished from the valley fill due to its higher surface position. The valley side consists of the sedimentological units coversand (Bisschops, 1973), which partly consists of 'Brabant loam' (Vink, 1949; Schokker, 2003), and fluvioperiglacial deposits (Bisschops, 1973). Locally, strongly consolidated, in situ peat can be found within the unit. The texture ranges from very fine sand to medium fine sand (105 to $420 \mu \mathrm{m}$ ), and loamy sand to clay loam. The colours are light grey, brown and yellow. Beds of OM are mostly absent, except for sporadical laminae of several millimetres.

Here we will further elaborate on the lithogenetic units that form the Holocene valley fill. 
Overbank deposits consist of very fine sand to fine sand (median grain size 105 to 210 $\mu \mathrm{m}$ ), peaty sand, and loamy sand to clay loam. The colour of the unit is usually light grey to dark brown. The OM content is low $(<1 \%)$ when not peaty. Sometimes small fractions of reworked plant remains or loam are present, which occur in layers of several millimetres to several centimetres in thickness. The unit mostly overlies the other units, but can be found within the unit in situ peat as well. The unit is usually found near a channel or channel-fill, and has a thickness of 1 to $2 \mathrm{~m}$, but becomes thinner further away from the channel or channel-fill. The unit can be recognized by its horizontal layering in the GPR profiles when the GPR results are of sufficient quality (Figure 3.3).
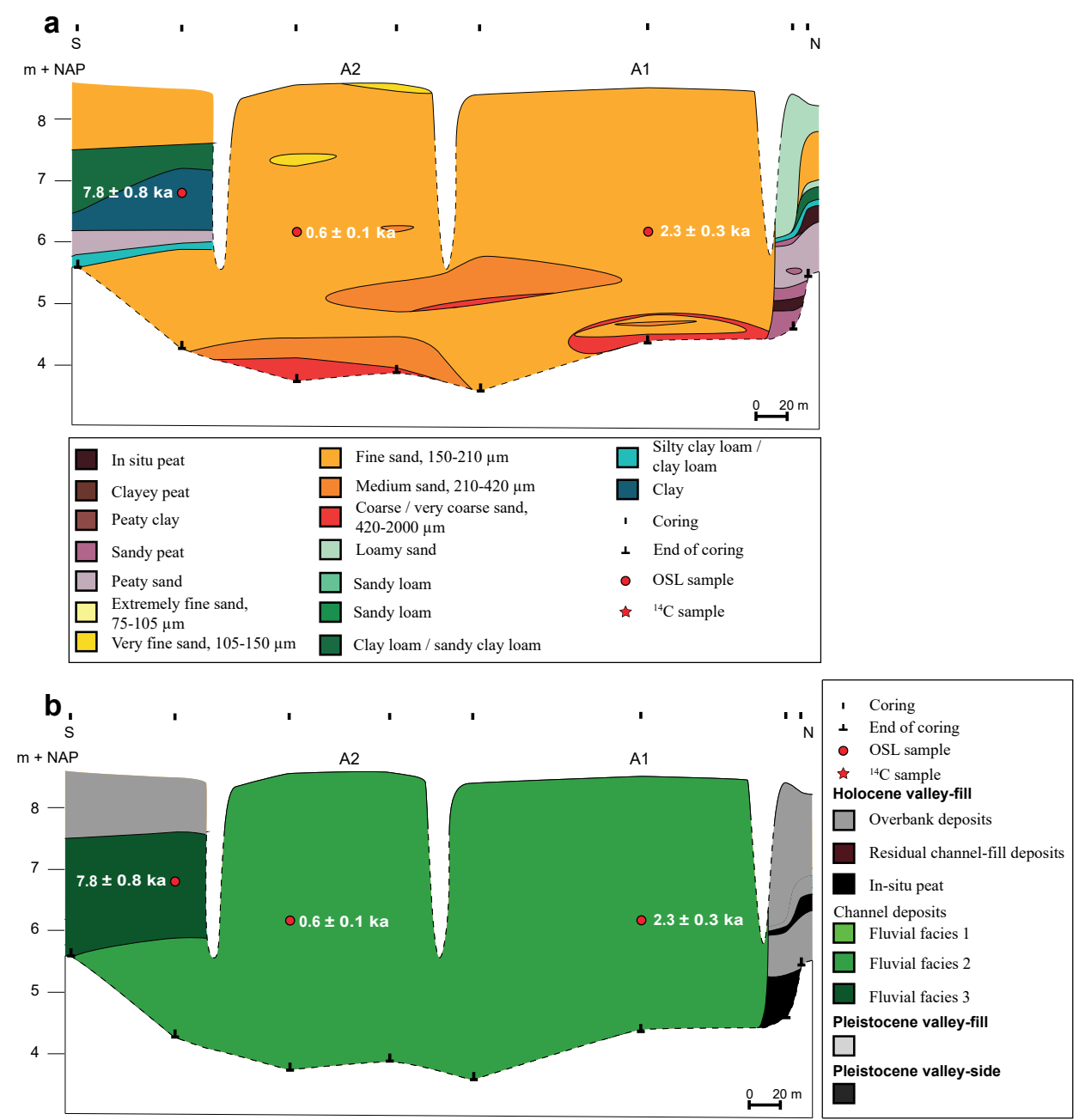

Figure 3.5 Cross-sections of the valley fill (location in Figure 3.3a) including the OSL sample locations. a) Lithological cross-section, b) lithogenetic cross-section. Location of the bend complex A-1 and A-2 are indicated (see Figure 3.2d). 
Residual channel-fill deposits range in texture from loamy sand to clay loam, peaty sand and clayey peat. In situ peat can be present near the base of the unit. The colour of the unit is mostly dark brown, grey, green or blue. The unit is generally humic (OM content 2 to $4 \%$ ) or very humic (OM content 4 to $8 \%$ ). The unit is structureless when consisting of peat, or else consists of layers of OM, sand or loam with thicknesses of several millimetres to several centimetres. The degree of consolidation increases with depth when overlain by sediments, and the unit was difficult to core below ca. $2 \mathrm{~m}$ depth. The unit has a relatively low width/thickness ratio, a thickness of 2.5 to $4 \mathrm{~m}$, and is located on top of and alongside channel deposits. The unit strongly reflects the GPR signal, but the unit base can be recognized in the GPR profile as a concave structure (i.e. depression, Figure 3.3). When the GPR profile quality allows, the horizontal or concave layering can be recognised within the unit (e.g. Figure 3.4a,b).

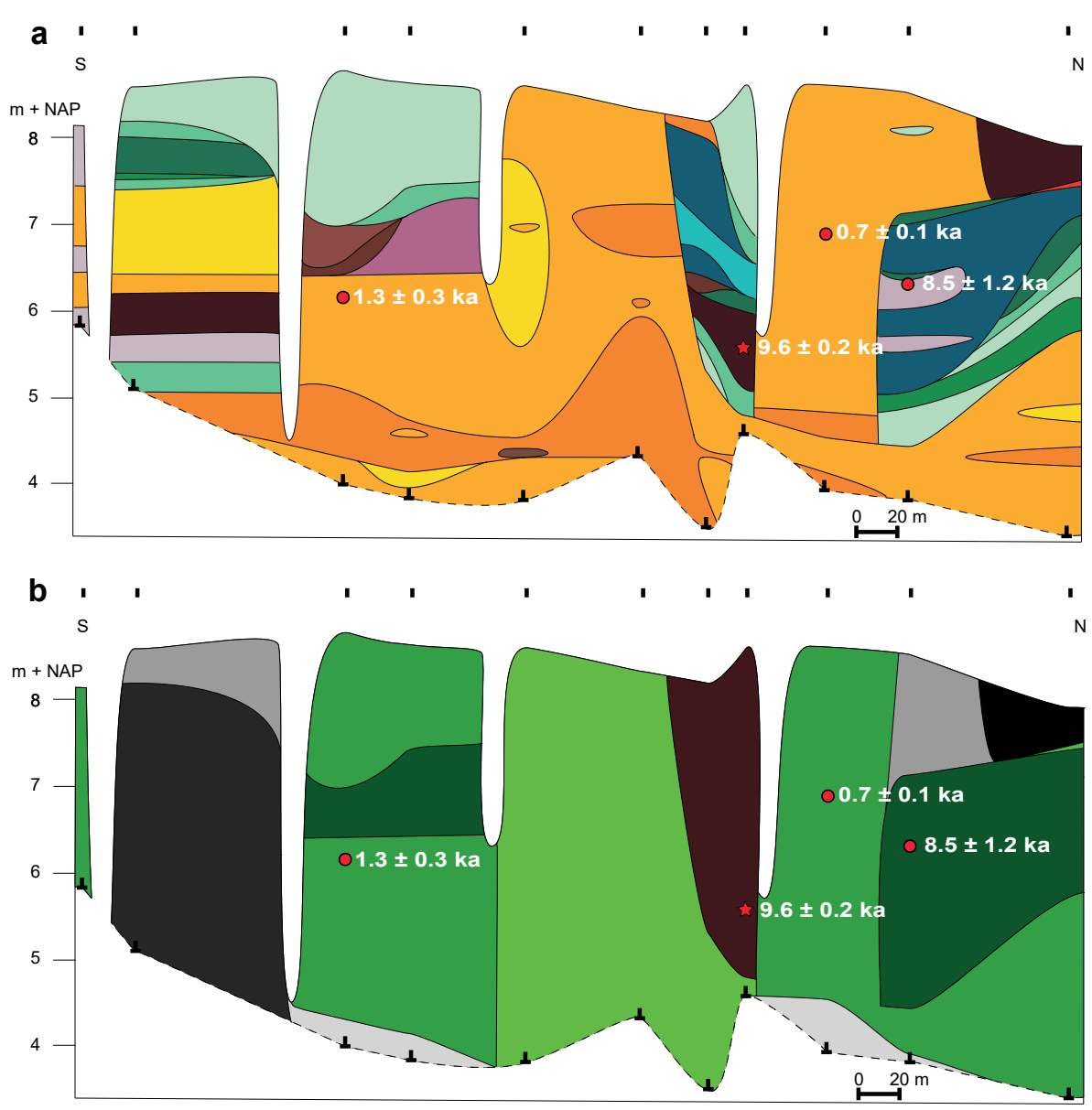

Figure 3.6 Cross-sections of the valley fill (location in Figure 3.3c) including the OSL and ${ }^{14} \mathrm{C}$ sample locations. a) Lithological cross-section, b) lithogenetic cross-section. Legend indicated in Figure 3.5. 
Channel deposits were split into three different Fluvial facies, in order to distinguish different types of channel deposits. Fluvial facies 1 consists of moderately well sorted clastic sediments varying in texture from very fine sand to coarse sand (median grain size 105 to $600 \mu \mathrm{m}$ ). The colour of the unit is light brown to dark grey. A fining upward sequence is often present with medium fine to coarse sand at the bottom of the unit (channel lag) containing up to $15 \%$ of gravel, and very fine sand, loamy sand or sandy loam at the top. The colour of Fluvial facies 1 is light grey or brown. Organic and loamy beds are mostly absent. The unit has a thickness of 4 to $5 \mathrm{~m}$ and reaches the present surface, although the unit is generally not recognizable from the topography. The unit is relatively difficult to distinguish from the Pleistocene valley fill, except from its location near the surface. Gently inclined strata $\left(1^{\circ}\right.$ to $\left.3^{\circ}\right)$ can be visible in the GPR profile (Figures 3.3 and 3.4e,f). Fluvial facies 2 is similar to Fluvial facies 1 based on texture, geometry, extent and the presence of a fining upward textural trend. However, the colour of Fluvial facies 2 is darker, dark brown or grey, and Fluvial facies 2 contains well developed layers of fluvially reworked plant remains (e.g. wood, leaves, seeds) and organic layers with thicknesses of several centimetres up to several decimetres. Loamy beddings of several centimetres thick can be present. When located near the surface, steeply inclined strata $\left(14^{\circ}\right.$ to $\left.28^{\circ}\right)$ are visible in the GPR profiles (Figures 3.3 and 3.4ad). Fluvial facies 3 consists of (peaty) sandy, clayey or silt loam, clay or clayey peat. The colour of Fluvial facies 3 is dark brown, grey, green or blue. Fluvial facies 3 is generally humic (OM content 2 to $4 \%$ ) to very humic (OM content 4 to $8 \%$ ). The Fluvial facies can be structureless, or can contain layers of fluvially reworked plant remains, organic and loamy layers with thicknesses of several millimetres to several centimetres. The total thickness of Fluvial facies 3 ranges from several decimetres up to $2.5 \mathrm{~m}$. Fluvial facies 3 can be found within or on top of Fluvial facies 2. Thin deposits of Fluvial facies 3 can also be present in Fluvial facies 1 . Fluvial facies 3 is often found along the margins of the valley or at the upstream side of a concave bank. Overbank deposits sometimes overlie Fluvial facies 3. The unit strongly reflects the GPR signal in contrast to Fluvial facies 1 and 2 , and can consequently be recognized from the GPR profiles. 


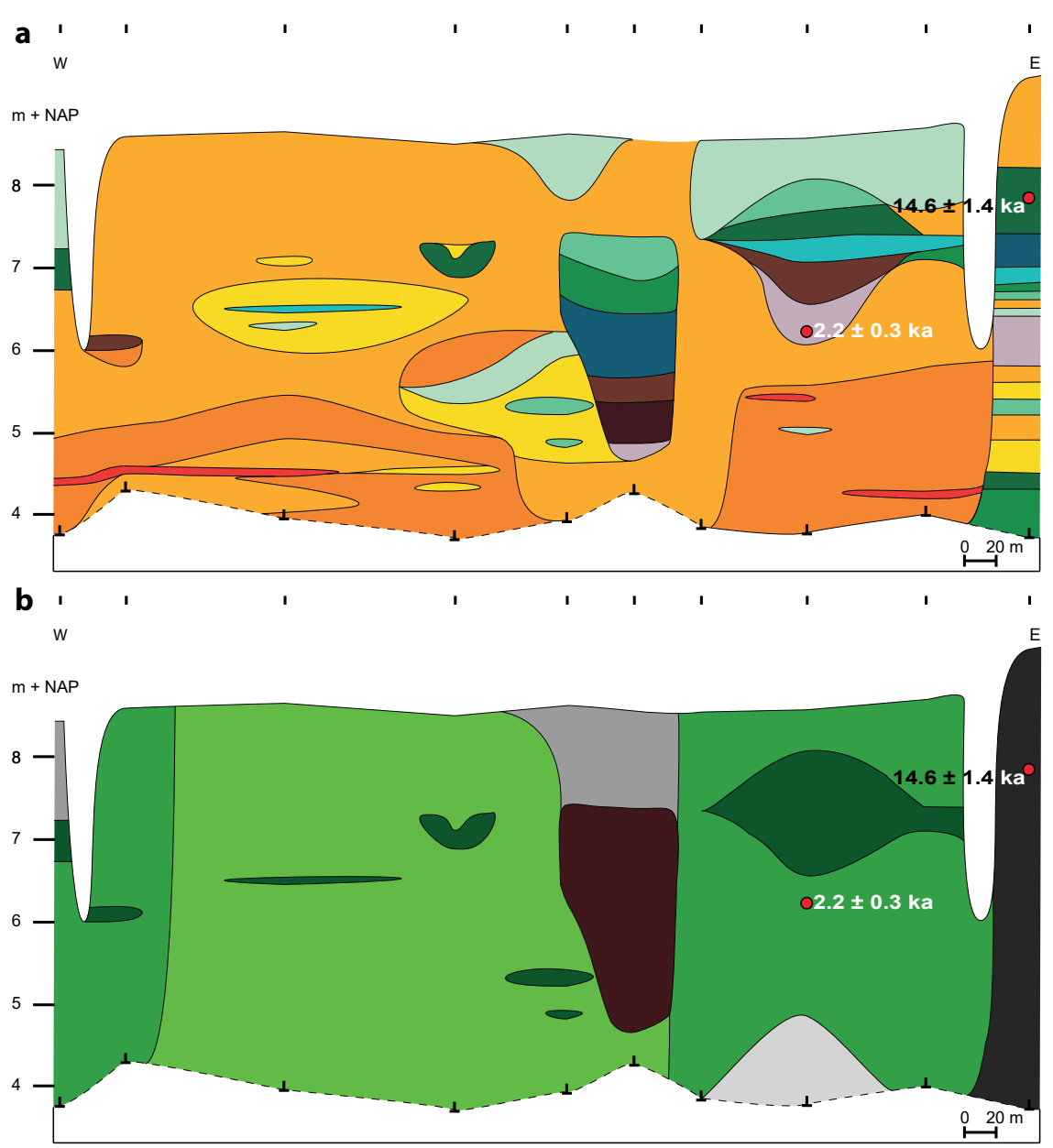

Figure 3.7 Cross-sections of the valley fill (location in Figure 3.3c) including the OSL and ${ }^{14} \mathrm{C}$ sample locations. a) Lithological cross-section, b) lithogenetic cross-section. Legend indicated in Figure 3.5.

Different types of channel deposits can be interpreted from the described fluvial facies. Fluvial facies 1 was interpreted as point-bar deposits with a fining upward sequence. The GPR profile clearly shows lateral accretion surfaces, with a slope of approximately $1^{\circ}$ to $3^{\circ}$. Gently inclined strata may indicate a former river channel with a relatively large width/depth ratio (Leeder, 1973; Willis, 1989).

Fluvial facies 2 was also interpreted as point-bar deposits, with a clear fining upward sequence. The bottom and middle of the point-bar consist of thick intervals of stacked plant remains and organics, interlayered within the sandy point-bar. The presence of these thick intervals of plant remains result from the preservation of pool-infills on the river bed, or from counter-rotating flows on the convex side of a sharp river bend (Nanson, 2010; Blanckaert, 2011; Blanckaert et al., 2013). The steep inclination in 
the GPR profiles $\left(14^{\circ}\right.$ to $\left.28^{\circ}\right)$ indicates that the associated channel had a relatively low width/depth ratio (Leeder, 1973).

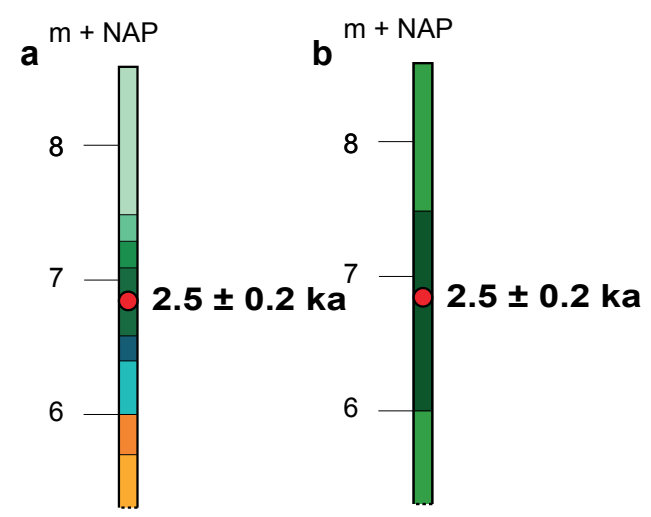

Figure 3.8 Borehole of the valley fill (location in Figure 3.3e) including the OSL location. a) Lithological sequence, b) lithogenetic sequence. Legend indicated in Figure 3.5.

Fluvial facies 3 mainly represents counterpoint deposits and upper or middle pointbar deposits. Counterpoint deposits occur as thick deposits of structureless or layered fine sediments and organics along the margins of the valley or on the upstream side of concave bends, which suggests deposition from suspension (Carey, 1969; Hickin, 1979; Page and Nanson, 1982; Makaske and Weerts, 2005; Smith et al., 2009; Smith et al., 2011). Counter-rotating flows, i.e. flow separation, on the concave side of a river bend promote the growth of these counterpoint deposits, which interfinger with point-bar deposits (Hickin, 1986; Makaske and Weerts, 2005; Smith et al., 2011). Flow separation mainly occurs in sharp river bends (Nanson, 1980; Nanson, 2010; Blanckaert, 2011; Blanckaert et al., 2013). Our interpretation matches the interpretations by Makaske and Weerts (2005) in the Hennisdijk channel-belt and Smith et al. (2011) in the meandering Peace River, who described the muddy, loamy and organic nature of these counterpoint deposits. Fluvial facies 3 can also be interpreted as middle or upper point-bar deposit, being part of the fining upward sequence of Fluvial facies 2 . In this setting, Fluvial facies 3 was deposited near the downstream tail of a point-bar when flow separation occurs on the convex side of a sharp bend (Nanson, 1980; Nanson, 2010; Blanckaert, 2011; Blanckaert et al., 2013), explaining the relatively organic and fine-grained nature of point-bar deposits found in the Dommel River. Point-bars can consist of substantial quantities of organics, loam and mud, which seems especially characteristic for lowenergy meandering river systems (Makaske, 1998 p. 225; Makaske and Weerts, 2005; Smith et al., 2009). 


\section{Chapter 3}

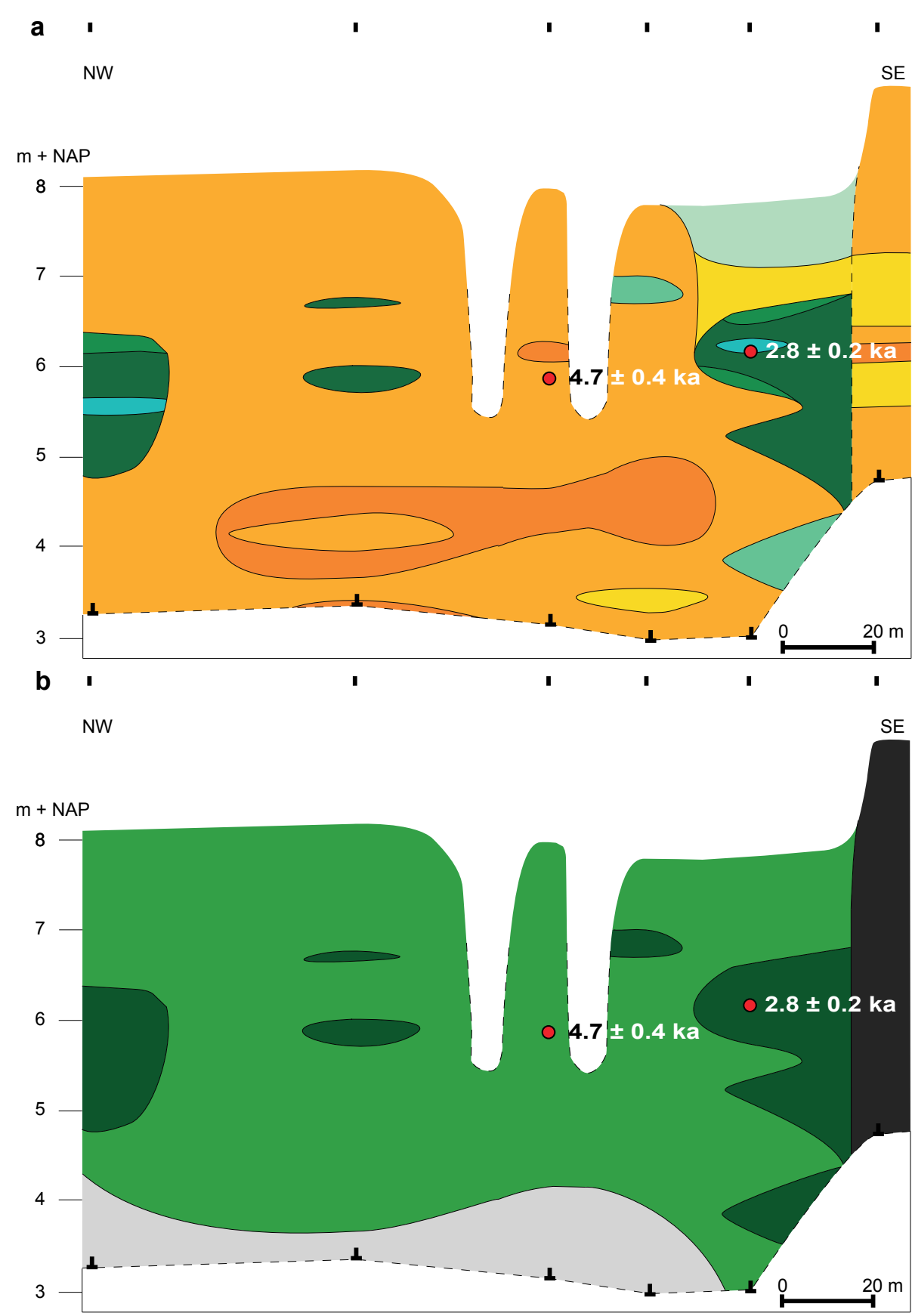

Figure 3.9 Cross-sections of the valley fill (location in Figure 3.3e) including the OSL sample locations. a) Lithological cross-section, b) lithogenetic cross-section. Legend indicated in Figure 3.5. 


\subsubsection{Cross-sections}

Here we describe the lithological and lithogenetic cross-sections shown in Figures 3.5 to 3.10. The dating results are shown in Table 3.1, and also indicated in the cross sections. Figure 3.5 shows a cross-section of bend complexes A-1 and A-2 (Figure 3.3a). On the southern side, Fluvial facies 3 is interpreted as counterpoint deposits with a depth of ca. $2 \mathrm{~m}$, lying on top of Fluvial facies 2 . These counterpoint deposits are relatively old ( 7.8 $\pm 0.8 \mathrm{ka}$ ), and hence the configuration relative to the palaeochannel, which is different from the recent Dommel channel, cannot be derived. Point-bar deposits on the inside of this bend complex are relatively young $(0.6 \pm 0.1 \mathrm{ka}$ ) (Figure 3.5). Bend complex A-1 is bordered on the northern side by thick Holocene overbank deposits and in situ peat. The point-bar deposits of A-1 are older $(2.3 \pm 0.3 \mathrm{ka})$ than those of bend complex A- 2 .

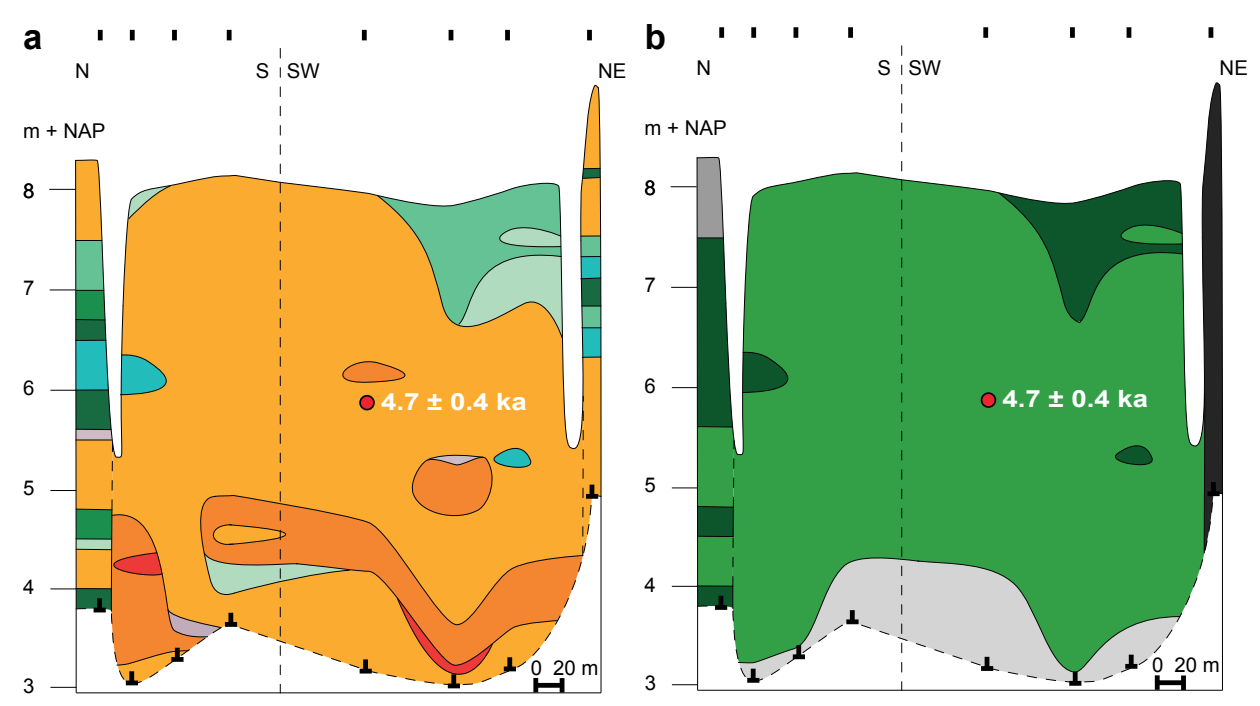

Figure 3.10 Cross-sections of the valley fill (location in Figure 3.3e) including the OSL sample locations a) Lithological cross-section b) lithogenetic cross-section. Legend indicated in Figure 3.5.

Figure 3.6 shows a cross-section of bend complex B, where the current Dommel River lies along the valley side in the southern part. The valley side deposits (Figure 3.3c) consist of clay loam and very fine sands, overlying compacted in situ peat. Point-bar deposits $(1.3 \pm 0.3 \mathrm{ka})$ are located north of the current Dommel River, which reach channeldepth thickness (ca. 4 to $4.5 \mathrm{~m}$ ). The middle point-bar deposits consist of consolidated clayey and sandy peat deposits (Fluvial facies 3). More point-bar deposits are located to the north, with peaty and loamy residual channel-fill deposits that reach as deep as the current Dommel River channel (Figure 3.6b). The in situ peat dates from $9.6 \pm 0.2 \mathrm{ka}$. A narrow, relatively young point-bar deposit (ca. $40 \mathrm{~m}$ wide, $0.7 \pm 0.1 \mathrm{ka}$ ) is located north of the bend complex, with a similar depth as the residual channel-fill deposits. The GPR 
cross-section shows steeply inclined strata reflecting the lateral accretion surfaces of the point-bar, and horizontal layering north of the point-bar (Figure 3.4c,d). Fluvial facies 3 was interpreted here as counterpoint deposits $(8.5 \pm 1.2 \mathrm{ka})$, which seems to interfinger with point-bar deposits towards the North, and have a similar depth as the point-bar and residual channel deposits that are present in the cross-section.

Figure 3.7 shows a cross-section perpendicular to the cross-section in Figure 3.6. A small point-bar deposit is located on the western side, reaching channel-depth thickness. Point-bar deposits are located east, showing gentle inclined lateral accretion surfaces (Figure $3.4 \mathrm{e}, \mathrm{f})$. Point-bar deposits $(2.2 \pm 0.3 \mathrm{ka})$ are lying in between the peaty/loamy residual channel-fill and the valley side, which have a thickness similar to the current Dommel River depth (ca. 4 to $4.5 \mathrm{~m}$ ). The middle of these point-bar deposits are relatively organic and loamy (Fluvial facies 3). The loamy top of the valley side deposits is interpreted as the 'Brabant loam' described by Schokker (2003) and dates from 14.6 $\pm 1.4 \mathrm{ka}$ (Kasse et al., 2016).

Figure 3.8 shows a coring from the outer bank of bend complex B (Fig. 3.3c). Surrounding corings on this part of the bend complex showed a similar succession of Fluvial facies 3 overlying Fluvial facies 2 . This part was interpreted as counterpoint deposits dating from $2.5 \pm 0.2 \mathrm{ka}$, and shows a similar age as the point-bar deposits on the inside of the bend complex in Figure 3.5. Figure 3.3c shows the extent of the counterpoint deposits along the valley side (all green-coloured corings) and the configuration relative to the channel that formed these counterpoint deposits.

Figure 3.9 shows counterpoint deposits along the south-eastern valley side of bend complex C (Figure 3.3e), dating from $2.8 \pm 0.2 \mathrm{ka}$ and interfinger with point-bar deposits. These counterpoint deposits are younger than the inner point-bar deposits (4.7 $\pm 0.4 \mathrm{ka}$ ), hence the younger counterpoint deposits were formed as a result of inward migration of the channel when it started to erode its older point-bar deposits. Both deposits reach a similar depth as the current Dommel River (ca. 4 to $4.5 \mathrm{~m}$ ).

Figure 3.10 shows a cross-section perpendicular to the cross-section in Figure 3.9. This cross-section shows that the channel is bordered by Fluvial facies 3 on the northern side, and by the valley side on the north-eastern side, which are interpreted as counterpoint deposits. Relatively narrow and thick (ca. 4 to $4.5 \mathrm{~m}$ ) point-bar deposits are present on the inside of the bend complex, with some loamy layers present within the point-bar deposits. 
Several lines of evidence indicate that aggradation was relatively limited (max. $0.5 \mathrm{~m}$ ) in the Dommel valley during the Holocene: 1) The bottom of the Early Holocene residual channel-fill (see Figure 3.6) occurrs at the same depth as the bottom of the Late Holocene point-bar deposits. 2) Middle Holocene channel lags are often located at the same depth as the current Dommel (ca. 4 to 4.5 m). 3) Lateral accretion surfaces from the old point-bars (both Fluvial facies 1 and 2) always start within $0.5 \mathrm{~m}$ depth from the surface (e.g. Figure 3.4). 4) Overbank deposits are only present on top of Late Glacial or Early Holocene deposits (e.g. Figures 3.5 to 3.7$)$.

\subsubsection{Spatial configuration}

Erosion-resistant deposits are abundantly present in the valley side and floodplain of the Dommel River, on both sides of the bend complexes (Figure 3.11). These erosion-resistant floodplain deposits consist of silt loam, clay loam and peaty deposits, of which many reach channel-depth thickness (Figures 3.5 to 3.10 ), and are consolidated at 2 to $4 \mathrm{~m}$ below the surface, further enhancing their resistance to erosion. The sedimentology of these fine-grained erosion-resistant deposits indicates that they mainly consist of residual channelfill deposits, middle point-bar deposits and counterpoint deposits.

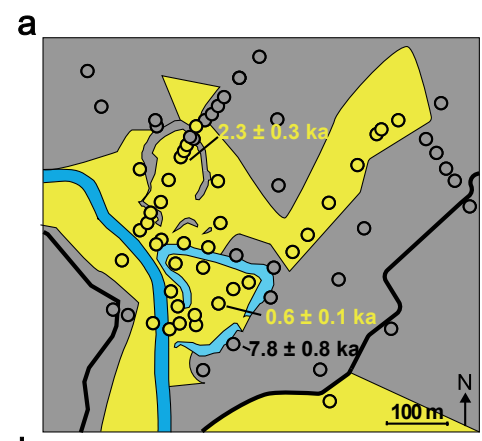

b
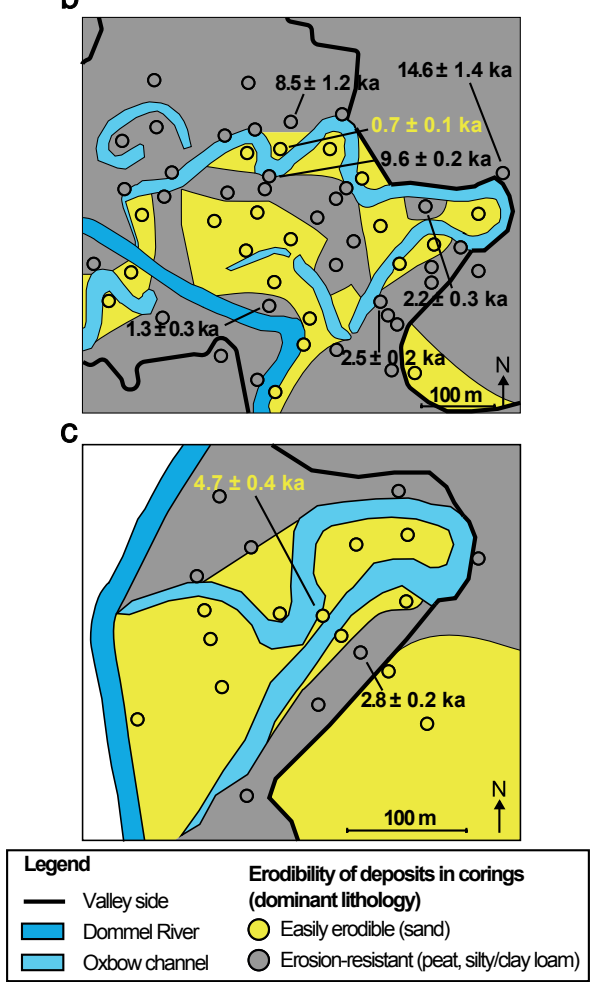

Figure 3.11 Simplified lithological maps showing the coring and dating (OSL and ${ }^{14} \mathrm{C}$ ) locations. Colours of the cores indicate the erodibility and dominant lithology at that location; map colours are based on spatial interpretation, based on coring information, surface morphology and GPR cross-sections. Ages shown in black are obtained on erosion-resistant material, while those in yellow are from easily erodible deposits. 


\subsubsection{Morphodynamics}

The results show that the Dommel River channel was largely constrained by its selfformed erosion-resistant deposits (Figure 3.11), and bends only migrated locally over relatively short distances where they were not restricted by erosion-resistant deposits in their outer banks. The Dommel River also shows relatively recent deposits of both easily erodible and erosion-resistant deposits (e.g. Figure 3.11c), but shows preferential erosion of the sandy deposits compared to the cohesive and organic deposits. Sharp secondary bends have formed within the primary bend complex forming a 'zigzagging' channel planform lying in between the erosion-resistant deposits (Figure 3.11), resulting in a tortuous river planform with limited channel mobility. Here we refer to secondary bends when smaller bends form within a larger, primary bend. Sharp secondary river bends formed because the river eroded its own sandy point-bar deposits due to their lower resistance to erosion compared to the fine-grained depositional units outside of the primary bend complex. Hence, the hypothesis (Sect. 3.1) can be confirmed. In Sect. 3.4, the conceptual model of this self-constraining of low-energy meandering rivers will further be developed and tested for other meandering rivers.

\subsection{Conceptual model}

\subsubsection{Concepts of self-constraining low-energy meandering rivers}

A conceptual map illustrates the self-constraining process of low-energy meandering rivers, conceptualized from the Dommel River reconstructions (Figure 3.12a). The river mainly erodes its sandy point-bar deposits due to their lower resistance to erosion compared to other, more cohesive depositional units (Figure 3.12a). As a consequence of preservation differences, the fraction of easily erodible, non-cohesive sediments in the floodplain decreases with time (Figure 3.12b) (Smith et al., 2009). Here we define a self-constraining river as 'a river of which the channel mobility is increasingly hampered with time by self-formed erosion-resistant banks'. This self-constraining is accompanied by increase in planform tortuosity due to the formation of sharp river bends (Figure $3.12 \mathrm{a}, \mathrm{c})$, which is a phenomenon commonly found in low-energy meandering rivers that are laterally restricted by erosion-resistant deposits (Turnbull et al., 1966; Leeder and Bridges, 1975; Hickin, 1986; Güneralp and Rhoads, 2011). Flow separation in sharp river bends may lead to the formation of counterpoint deposits (Leeder and Bridges, 1975; Smith et al., 2009) (Figure 3.12a), which are generally cohesive due to incorporation of silt and organic material. Also cohesive middle point-bar deposits may form due to flow separation. Residual channel-fill deposits result from neck cut-offs that are promoted by preferential erosion of the sandy point bars instead of erosion of the fine-grained deposits (example of almost cut-off channel complex C, Figure 3.11c) 
(Hooke, 2007). Residual channel-fills become fine-grained and organic when diversion angles to the cut-off channel are high (Constantine et al., 2010), which is especially common in rivers with tortuous planforms. These newly formed erosion-resistant deposits reach channel-depth thickness, hence their thickness scales with river size, and they further foster the planform tortuosity and formation of sharp bends (Figure $3.12 \mathrm{~b}, \mathrm{c})$. The erosion-resistance of these deposits increases even further with time as a result of consolidation. Figures $3.12 \mathrm{~b}, \mathrm{c}$ describe an initially exponentially increasing response due to the positive feedback between the formation of erosion-resistant deposits and increase in planform tortuosity. The average channel activity (Figure 3.12d) decreases simultaneously with the relative increase of erosion-resistant deposits in the vicinity of the channel (Figure 3.12b), slowing down the positive feedback loop, and eventually resulting in a low-energy meandering river with inhibited channel mobility (Figure 3.12d), predominantly cohesive banks (Figure 3.12b) and a tortuous planform (Figure 3.12c).

For simplicity, we only show the three main erosion-resistant deposits found in the Dommel River: residual channel-fill deposits, counterpoint deposits and the valley side. Other erosion-resistant deposits may be more dominant in other low-energy river systems, such as overbank deposits, fine-grained middle point-bar deposits or oblique accretion deposits (e.g. Page et al., 2003), but they have the same effect on the river planform. Easily erodible deposits mainly consist of point-bar deposits for the Dommel River.

Sylvester et al. (2019) showed that bends with the highest curvatures show the highest migration rates. This was confirmed by observations on the intertidal mudflat, where the highest migration rates occurred in the sharp river bends due to flow separation, but the average river channel migration was low (Kleinhans et al., 2009). The self-constraining conceptual model also confirms that sharp bends show the highest displacement, because the remaining part of the river channel is relatively laterally stable due to the self-constraining (Figures 3.11 and 3.12). However, when comparing channel mobility between meandering rivers, we expect that the average channel mobility of rivers with sharp bends is generally lower than rivers with gentle, freely meandering bends (Hooke, 1980; Hudson and Kesel, 2000; Hooke, 2007; Smith et al., 2009; Bogoni et al., 2017), because the channel mobility of self-constraining rivers is inhibited and limited to small sections of the floodplain (Figures 3.11 and 3.12). 


\section{Chapter 3}

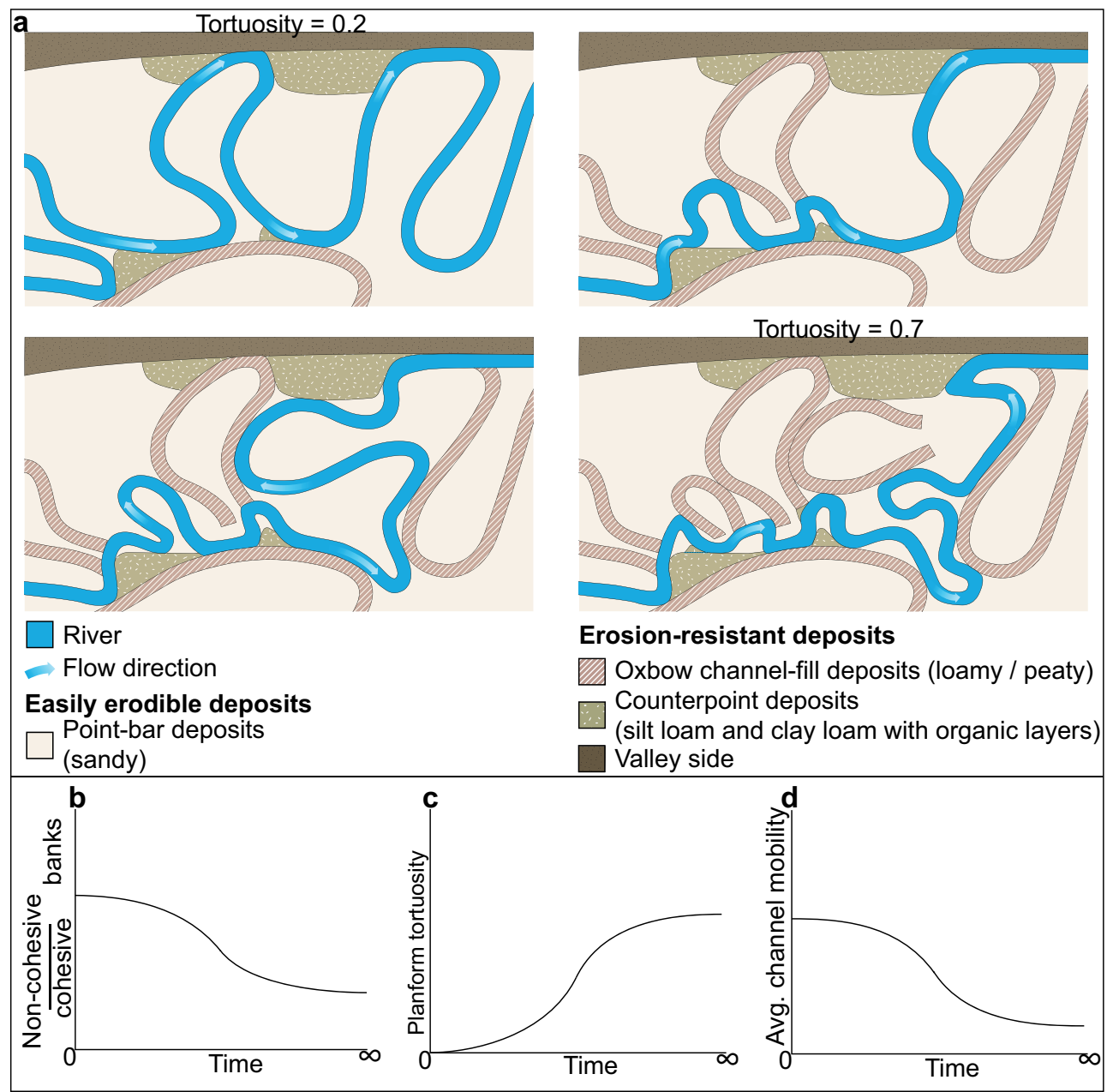

Figure 3.12 Self-constraining of a meandering river illustrated. a) Conceptual maps showing the potential development of floodplain deposits and channel planform of a self-constraining river, assuming that neck cut-offs and counterpoint deposits immediately form erosion-resistant layers at the moment of cut-off or deposition. The tortuosity is indicated for the first and last timeframe. Conceptual graphs showing the long-term evolution of b) bank cohesiveness, c) planform tortuosity, and d) lateral migration rate. 


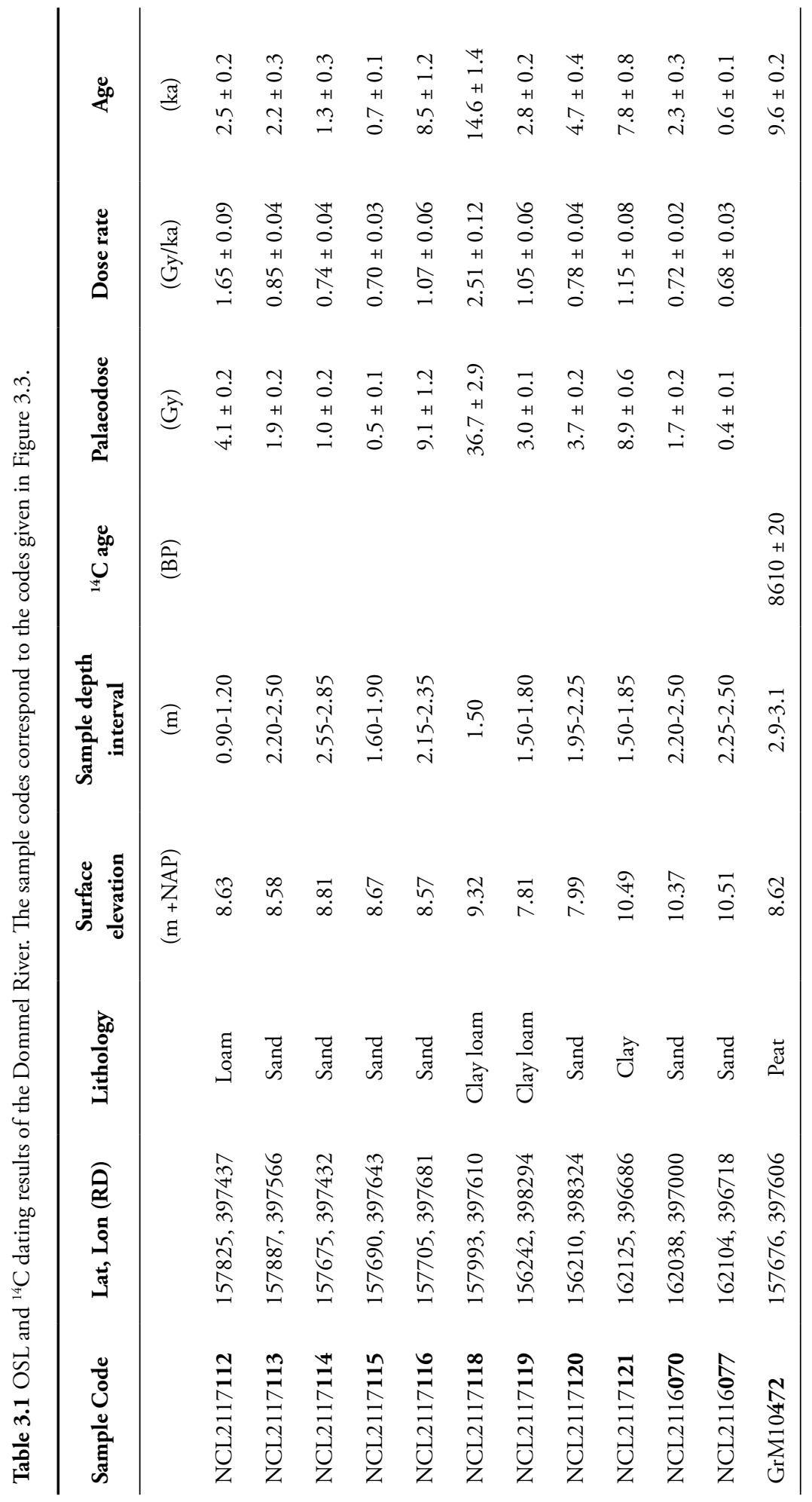




\subsubsection{Applicability to other low-energy meandering rivers}

To investigate whether the concepts of self-constraining are generally applicable, we combined the information on potential specific stream power, erosion-resistance of the river banks, and planform tortuosity for the 47 different-sized meandering river reaches of which we collected these data (Figure 3.13). As described in Sect. 3.2.6 these rivers are all alluvial rivers with no evidence of strong modification by humans, all rivers are laterally connected with their floodplain, and are not strongly incising or aggrading (Kleinhans and Van den Berg, 2011).

The data shown in Figure 3.13 depict that rivers with tortuous planforms occur only when river energy is below the threshold required to erode the erosion-resistant banks (Julian and Torres, 2006). The minimum required potential specific stream power for bank erosion was derived by applying relations from Julian and Torres (2006) and Kleinhans and Van den Berg (2011) (Eqs. 3.2 and 3.3):

$\tau_{c}=0.1+0.18 S C+0.0028 S C^{2}-2.34 * 10^{-5} * S C^{3}$

$\omega_{\text {crit }}=\frac{\tau_{c}^{1.5} C}{\sqrt{\rho g}}$

where $\tau$ is the critical shear stress (Pa) to erode the SC-fraction (\%) in the banks, and $C$ is the Chézy coefficient $\left(\mathrm{m}^{0.5} \mathrm{~s}^{-1}\right)$, which was taken here as the median of the values for the rivers used in our analysis $\left(36 \mathrm{~m}^{0.5} \mathrm{~s}^{-1}\right)$. Rivers below the threshold will predominantly erode easily erodible banks (with below-average SC-fractions), resulting in an increasing fraction of erosion-resistant deposits with time. For river energy above the threshold the river is able to erode the erosion-resistant banks, resulting in a reduction of these erosion-resistant deposits (decreasing average SC-fractions) and a lower planform tortuosity (Figure 3.13). Gravel-bed rivers hardly develop tortuous planforms, because they require high river energy to mobilize the river bed material. At such energy they are able to erode banks irrespective of bank erodibility (Figure 3.13). 


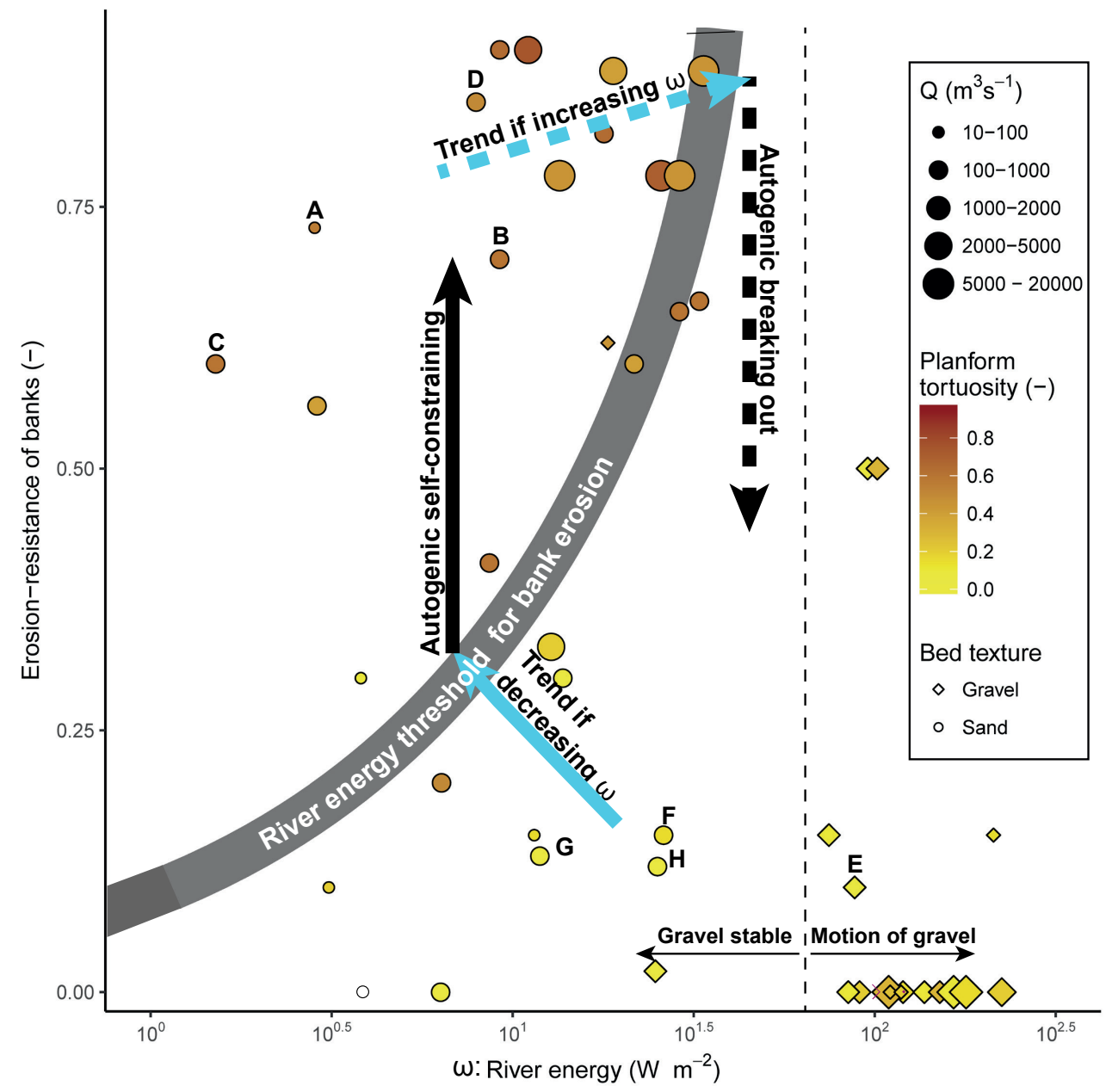

Figure 3.13 Erosion-resistance of banks (proxy: average silt-plus-clay fraction of river banks) plotted against river energy (proxy: potential specific stream power, $\omega$ ) for a dataset of 47 rivers (Van den Berg, 1995; Kleinhans and Van den Berg, 2011). For each of the data points, effective channel-forming discharge (Q) (Kleinhans and Van den Berg, 2011), planform tortuosity and bed texture are shown. The thick grey line represents the minimum river energy needed to erode the river banks (Woodyer et al., 1979; Page et al., 2003; Julian and Torres, 2006; Kleinhans and Van den Berg, 2011). The thick arrows indicate the hysteresis cycle of self-constraining and breaking out, in black and blue the autogenic and allogenic processes, respectively. Dashed arrows represent hypothetical arrows. The labelled rivers correspond to rivers shown in Figure 3.1, or reconstructed Late-Glacial systems (see methods section on reconstruction). A-D refer to rivers with sharp bends, E-H refer to rivers with classical meandering planforms: A) Dommel River (Figure 3.1a), B) Murrumbidgee River (Figure 3.1b), C) Barwon River (Figure 3.1c), D) San Antonio River (Figure 3.1d), E) Waterton River (Figure 3.1e), F) Assiniboine River (Figure 3.1f), G) Late-Glacial Dommel River, H) Late-Glacial Niers River. 


\subsection{Discussion}

\subsubsection{Prerequisites}

Meandering rivers may become self-constraining under specific, but common, conditions. Firstly, river energy should be insufficient to erode the cohesive depositional units, but sufficient to erode the non-cohesive material. These conditions apply to low-energy meandering rivers, especially sand-bed rivers that have a low threshold for sediment motion (ca. $10^{-2} \mathrm{~W} \mathrm{~m}^{-2}$ for sand-bed rivers). Our analysis demonstrates that self-constraining occurs irrespective of river size (ranging from bankfull discharges of 22 $\mathrm{m}^{3} \mathrm{~s}^{-1}$ for the Dommel River to $1.7^{*} 10^{4} \mathrm{~m}^{3} \mathrm{~s}^{-1}$ for the Purus River), provided that river energy is low (Figure 3.13). River energy is controlled by allogenic factors like climate and land cover that change with time (Candel et al., 2018b), and is therefore an allogenic control determining the occurrence of the autogenic processes of self-constraining.

Secondly, the river should transport a heterogeneous load of cohesive and non-cohesive material to be able to build a heterogeneous floodplain. Low-energy rivers commonly have a relatively fine-grained sediment load, and form floodplains with cohesive depositional units (Nanson and Croke, 1992). Rivers with a strictly non-cohesive sediment load will not develop self-formed erosion-resistant banks (Van Dijk et al., 2012). Channel mobility of these rivers may only become restricted by, for example, vegetation (Van Oorschot et al., 2016), soil formation (Bätz et al., 2015), bank protection measures (Hesselink et al., 2003) or peat formation (Candel et al., 2017).

Finally, sufficient time is required during which the conditions fostering self-constraining of the channel prevail; thus channel belts should not frequently be abandoned due to avulsions. Such favourable conditions occur where rivers are located in a valley setting, in which valley sides may contribute to the self-constraining process when they are erosion-resistant (Figure 3.12a). Strong aggradation or incision may also reset the selfconstraining, because they may potentially lead to overtopping or undercutting of the erosion-resistant deposits, respectively. Therefore, aggradation and incision rates should be relatively limited, as is the case with rivers used in this dataset (Kleinhans and Van den Berg, 2011). 


\subsubsection{Implications}

Although counter-intuitive, increase of river energy (e.g. because of climate or land cover changes) in self-constraining, low-energy meandering rivers may initially accelerate the self-constraining process and will lead to an increase of erosion-resistant deposits, provided that river energy is still below the threshold (Figure 3.13). If river energy exceeds the threshold, the self-constraining feedback loop is broken. We conjecture that such rivers may then be able to erode the erosion-resistant deposits and partly replace them with easily erodible, non-cohesive deposits (although convincing evidence of rivers that have crossed this threshold is presently lacking). The existence of two system states would create a hysteresis cycle (Figure 3.13).

A striking example of the self-constraining part of this hysteresis cycle is provided by river responses in many temperate regions during interglacial-glacial cycles. Many rivers in these regions were braiding during the Pleniglacial and changed to meandering during the Late Glacial (Vandenberghe, 1995, 2001). Valley slopes, bankfull discharges and thus river energy were high during the Late Glacial compared to the Holocene, due to low sea levels and high runoff from snowmelt peaks, and rivers formed their valleys within the non-cohesive river deposits that had previously been deposited by braided rivers (Mol et al., 2000). Late-Glacial rivers were commonly high-energetic, laterally migrating and planform tortuosity was low (Figure 3.13, e.g. the Late-Glacial Dommel and Niers Rivers (Kasse et al., 2005)). During the Holocene, river energy decreased, and this period provided sufficient time for rivers to develop tortuous planforms by selfconstraining (Figures 3.12 and 3.13). Figure 3.13 indicates that these self-constraining meandering rivers can only break out of their constraints when river energy significantly increases to levels above the threshold. This may occur in a transition to a glacial period (Vandenberghe, 1995, 2008), although in such cases strong incision or aggradation may take place as well (violating the conditions discussed in this paper).

The hysteresis loop indicates that self-constraining, low-energy meandering rivers are highly resilient for bank erosion due to changes in river energy. This resilience may aid river management and reduce risk of infrastructure damage by channel migration, but there is always a risk for sudden unexpected and unwanted enhanced river dynamics when the threshold is crossed. Changes in the catchment land cover such as urbanization, peat extraction or deforestation may result in increase of river energy by increase of peak flows (Candel et al., 2018b). When river energy increase is sufficient, the self-constraining rivers will be replaced by actively migrating meandering rivers. Such river dynamics response to energy increase may become unexpected, and may have catastrophic consequences. We recently documented a channel pattern change for the Overijsselse Vecht River (Candel et al., 2018b), showing that an increase in peak 
discharge changed a laterally stable river into a meandering river with lateral migration rates of 2 to $3 \mathrm{~m} \mathrm{yr}^{-1}$ about 400 years ago.

\subsection{Conclusions}

Based on a palaeogeographic reconstruction of the low-energy Dommel River (The Netherlands) we show that low-energy meandering rivers may self-constrain their planform by preferential preservation of erosion-resistant deposits. This process explains the typical tortuous planform and low dynamics of these low-energy rivers. Selfconstraining occurs when low-energy rivers predominantly erode the easily erodible, non-cohesive depositional units, while they continuously form both easily erodible and relatively erosion-resistant deposits. With time, the proportion of erosion-resistant deposits increases, leading to a constrained, tortuous river planform that has limited channel mobility. Preconditions of this self-constraining are low-energy meandering rivers that are alluvial, have a heterogeneous sediment transport, do not strongly incise or aggrade and have an active channel belt for a sufficient long time period. The conceptual model of self-constraining is validated for a dataset of 47 meandering rivers, and the critical threshold of river energy was derived. Rivers with a river energy below this critical threshold tend to have tortuous planforms and banks with a high silt-plusclay fraction, in contrast to rivers with a river energy above this critical threshold. We conjecture that a hysteresis cycle exists, which is controlled by allogenic factors such as land use and climate. Rivers self-constrain when their river energy is below the critical threshold and bank stability increases with time, enhancing the resilience for bank erosion of the system. Rivers break out of the self-constraining once the river energy crosses the critical threshold.

\section{Acknowledgments}

The authors would like to thank Alice Versendaal and Erna Voskuilen for their help with the OSL laboratory analysis, Meike Schipper for the illustration design of Figure 3.12, Renathe Kamstra for her help in the field, Martin Gibling, Jelmer Nijp and Elizabeth Chamberlain for discussion on the concepts. We would also like to thank Staatsbosbeheer, Brabants Landschap and Waterschap De Dommel for the access to and the insight knowledge of the field sites. 




\section{Chapter 4}

\section{Late Holocene channel pattern change from laterally stable to meandering - a palaeohydrological reconstruction}




\title{
Chapter 4
}

\begin{abstract}
River channel patterns may alter due to changes in hydrological regime, related to changes in climate andlor land cover. Such changes are well documented for transitions between meandering and braiding rivers, whereas channel pattern changes between laterally stable and meandering rivers are poorly documented and understood. We hypothesize that many low-energy meandering rivers had relatively low peak discharges and were laterally stable during most of the Holocene, when climate was relatively stable and human impact was limited. Our objectives of this work are to identify a Late Holocene channel pattern change for the low-energy Overijsselse Vecht River, to develop and apply a novel methodology to reconstruct discharge as a function of time following a stochastic approach, and to relate this channel pattern change to reconstructed hydrological changes. We established that the Overijsselse Vecht was laterally virtually stable throughout the Holocene until the Late Middle Ages, after which large meanders formed at lateral migration rates of about $2 \mathrm{~m}$ $y r^{-1}$. The lateral stability before the Late Middle Ages was constrained using a combination of coring information, ground-penetrating radar $(G P R)$, radiocarbon $\left({ }^{14} C\right)$ dating, and optically stimulated luminescence (OSL) dating. We quantified bankfull palaeodischarge as a function of time, based on channel dimensions that were reconstructed from the scroll bar sequence and channel cut-offs using coring information and GPR data, combined with chronological constraints from historical maps and OSL dating. We found that the bankfull discharge was significantly greater during the meandering phase compared to the laterally stable phase. Empirical channel and bar pattern models showed that this increase can explain the channel pattern change. The bankfull discharge increase likely reflects climate changes related to the Little Ice Age and/or land use changes in the catchment, in particular as a result of peat reclamation and exploitation.
\end{abstract}

Published as: Candel, J. H. J., M. G. Kleinhans, B. Makaske, W. Z. Hoek, C. Quik, and J. Wallinga, 2018. Late Holocene channel pattern change from laterally stable to meandering - a palaeohydrological reconstruction: Earth Surf. Dynam., v. 6, p. 723741. DOI: $10.5194 /$ esurf-6-723-2018 


\subsection{Introduction}

Channel patterns describe the planform of a river, which reflects the interaction of the river channel with its floodplain. Channel patterns are classically distinguished: laterally inactive channels consist of straight and sinuous stable planforms, whereas laterally active channels consist of meandering and braiding planforms (Leopold and Wolman, 1957; Nanson and Knighton, 1996). Flume experiments and field data have shown that the channel pattern depends on several variables (Kleinhans, 2010). Firstly, on the potential specific stream power, which is the product of the channel-forming discharge and valley slope (Nanson and Croke, 1992; Kleinhans and Van den Berg, 2011). Secondly, on the bank erodibility (Friedkin, 1945; Ferguson, 1987), which is determined by the presence of bedrock in the valley side (Turowski et al., 2008), the bank cohesiveness (Peakall et al., 2007) and vegetation (Millar, 2000; Gurnell, 2014). Thirdly, on the type and amount of sediment supply (Nanson and Croke, 1992; Gibling and Davies, 2012).

Channel patterns can change in response to environmental variations (Ferguson, 1987). Many examples of channel pattern changes from braiding to meandering and vice versa are known to be associated with glacial/interglacial oscillations (Vandenberghe, 1995; Vandenberghe, 2002). Especially studies on the last glacial-interglacial transition have shown the simultaneous occurrence of channel pattern changes with a changing climate (Vandenberghe et al., 1994; Kasse et al., 2016). Climate change affects the vegetation, sediment availability and discharge regime, and consequently the bank stability, sediment transport and potential specific stream power resulting in different channel patterns.

Within the Holocene, several examples of channel pattern changes are documented from braiding to meandering rivers and vice versa (Lewin et al., 1977; Passmore et al., 1993; Brewer and Lewin, 1998; Słowik, 2015). However, channel pattern changes between laterally stable and meandering rivers have rarely been reported (Lewin and Macklin, 2010), except where human intervention transforms meandering rivers into heavily regulated and laterally stable rivers by introducing weirs, dams, groynes and bank protection measures (Hesselink et al., 2003; Surian and Rinaldi, 2003; Słowik, 2013; Hobo et al., 2014). Also the partial abandonment of former meandering valleys may result in underfit, laterally stable rivers like the former Rhine branches in the Niers and Oude IJssel valley (Kasse et al., 2005; Janssens et al., 2012).

Many studies have reported increased fluvial activity (e.g. increased discharge, sediment transport and deposition, and bank erosion rates) in relation to human, environmental and climatic pressures during the Holocene (e.g. Hoffmann et al., 2008; Macklin et al., 2010; Notebaert and Verstraeten, 2010; Lespez et al., 2015; Notebaert et al., 2018). 
An example of increased fluvial activity is known from the Pine Creek (Idaho, USA), where mining and deforestation combined with intensive grazing resulted in an increase of discharge and sediment input, followed by river widening and an increase in bank erosion (Kondolf et al., 2002). The reverse change has been observed in settings as a result of afforestation (Liébault and Piégay, 2001; Kondolf et al., 2002), or increase of riparian vegetation fixing the channel banks (Eekhout et al., 2014; Corenblit et al., 2015; VargasLuna et al., 2018). The increase of fluvial activity during the Holocene was corroborated by an extensive review of existing studies concerning sediment accumulation in West and Central European river floodplains by Notebaert and Verstraeten (2010). They concluded that sedimentation rates increased during the Middle and Late Holocene due to environmental changes. However, it is unknown whether the channel pattern changed simultaneously with the floodplain, because no Early Holocene channel deposits representing a stable phase were identified. De Moor et al. (2008) hypothesized that the Geul River in southern Netherlands may have been relatively laterally stable during the Early and Middle Holocene, while it was actively meandering during the past 2000 years. Most of the floodplain deposits from the laterally stable phase have not been preserved, but De Moor et al. (2008) were able to reconstruct the bankfull depth for both periods. They estimated the bankfull depth to be a factor two to three higher during the Late Middle Ages compared to the Early and Middle Holocene, and related this change to human and climate impact.

We conjecture that the change from laterally stable to meandering has occurred in some rivers for which increased Holocene fluvial activity was reported. The fact that such changes were not reported in the literature, may either mean that critical conditions for channel pattern change were not reached, or that evidence of such transitions is poorly preserved or left unnoticed. Both laterally stable and meandering rivers may display sinuous planforms, but the geomorphic processes in both rivers are different. Laterally stable channels are rivers without meandering processes, i.e. helicoidal flows causing bar formation and bank erosion at a significant rate (Nanson and Knighton, 1996; Seminara, 2006; Kleinhans and Van den Berg, 2011). In fact, the bends and channel cut-offs in laterally stable rivers may be the result of random and local perturbations (e.g. falling trees, beavers, bank collapse after heavy rainfall, etc.) leading to very limited and local displacement of the channel. Meandering and laterally stable rivers should therefore be distinguished by their different patterns of bar and floodplain formation, rather than merely by planform (Kleinhans and Van den Berg, 2011; Candel et al., 2017). We suggest that identifying channel pattern changes requires more detailed historic accounts or a much higher resolution of subsurface data than usually gathered, because palaeochannels of laterally stable channels poorly preserve in the fluvial archive of meandering channel belts (Van de Lageweg et al., 2016), except when they have been 
cut off by random and local perturbations prior to the meandering phase. Using numeric (e.g. Van Oorschot et al., 2016) or scaled (e.g. Van Dijk et al., 2012) river simulation models is problematic for testing these ideas, because these have not yet been capable of reproducing channel pattern changes. This reflects the lack of understanding of river processes and patterns (Kleinhans, 2010), and the need to gather such information from field studies.

This research entails a case study focussing on a river where lateral activity during the past 500 to 600 years caused spectacular meandering: the Overijsselse Vecht in The Netherlands (Figure 4.1). Previous work on this system has identified a transition from braiding to meandering during the Late-Glacial (Huisink, 2000) while the meandering pattern remained throughout the Holocene until the river was channelized between 1896 and 1914 CE (Huisink, 2000; Neefjes et al., 2011). However, Quik and Wallinga (2018) found that the meanders were relatively young, with the oldest scroll bars dating from ca. 1400 to $1500 \mathrm{CE}$, by reconstructing meander formation using a combination of optically stimulated luminescence (OSL) dating of scroll bars and planform reconstruction based on historical maps. No fluvial deposits were found dating from before this period, except from a Holocene palaeochannel (here referred to as "Palaeochannel Q") in a ground-penetrating radar (GPR) profile recorded by Huisink (2000, p.123) $13 \mathrm{~km}$ upstream near Hardenberg (Figures 4.1b and 4.2). Palaeochannel Q is relatively small compared to the meandering channel, seems to lack scroll bars and was already cut off on the historical map of $1720 \mathrm{CE}$. Therefore, it is questionable whether the Overijsselse Vecht meandered prior to ca. $1400 \mathrm{CE}$. Alternatively, the river changed from a laterally stable into a meandering river during the Late Middle Ages. Our aims are (1) to identify whether a channel pattern change has occurred from laterally stable to meandering, by collecting and combining detailed subsurface and geochronological data of the river from the pronounced meandering phase and the preceding phase; (2) to develop a methodology to reconstruct bankfull discharge as function of time, using the scroll bar deposits and channel remnants as a geological archive of the former channel dimensions; (3) to test whether palaeohydrological changes may explain the potential channel pattern change; and (4) to elaborate on the potential causes for changes in discharge and channel pattern. 


\section{Chapter 4}

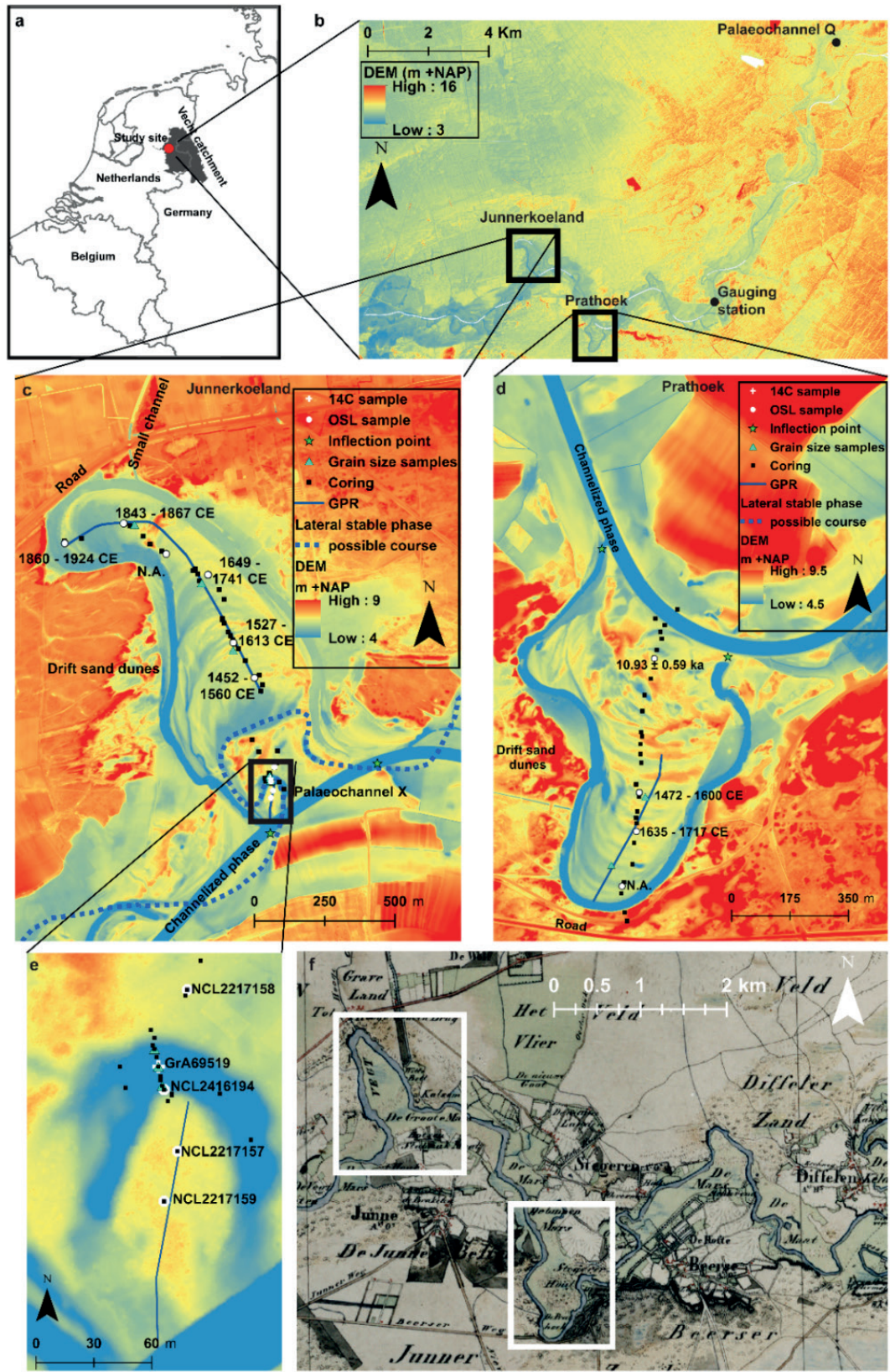

Figure 4.1 Maps of the Overijsselse Vecht. (a) Map showing the location of the Overijsselse Vecht catchment and the location of the study site. (b) Digital elevation map (DEM, Actueel Hoogtebestand Nederland, 0.5x0.5 m) (Van Heerd and Van't Zand, 1999) of the downstream section of the Overijsselse Vecht River, indicating both study sites: Junnerkoeland and Prathoek. DEM of the Junnerkoeland bend (c) and Prathoek bend (d), including locations of cores, OSL samples by Quik and Wallinga (2018), the OSL and ${ }^{14} \mathrm{C}$ samples from this study, the GPR transects, the grain size samples and inflection points. The possible historical course of Palaeochannel X according to Maas (1995) is indicated. (e) Zoomed-in figure of Palaeochannel X. (f) Topographical military map (TMK) dating from 1851 CE (CC-BY Kadaster, 2018; Van der Linden, 1973), showing the Overijsselse Vecht during its meandering phase. 


\subsection{Study area}

The Overijsselse Vecht (Figure 4.1) is a low-energy, sand-bed river flowing from Germany into The Netherlands, with an average annual discharge $\left(\mathrm{Q}_{\mathrm{m}}\right)$ of $22.8 \mathrm{~m}^{3} \mathrm{~s}^{-1}$ and a mean annual flood discharge $\left(\mathrm{Q}_{\text {maf }}\right)$ of $160 \mathrm{~m}^{3} \mathrm{~s}^{-1}$, derived from the gauging station in Mariënberg for the period 1995 to 2015 (see location in Figure 4.1b). The river has a length of 167 $\mathrm{km}$, its catchment covers $3785 \mathrm{~km}^{2}$ with the highest point $+110 \mathrm{~m}$ above sea level (asl), and a relatively uniform valley slope of $1.42^{*} 10^{-4}$ to $1.7^{*} 10^{-4}$ in the Dutch part of its trajectory (TAUW, 1992; Wolfert and Maas, 2007). The Overijsselse Vecht incised its current valley during the Late-Glacial within fluvioperiglacial sands, locally covered by aeolian coversands (Ter Wee, 1966; Huisink, 2000; Wolfert and Maas, 2007). During the Late Holocene, aeolian drift-sands formed along the Overijsselse Vecht as a result of agricultural overexploitation (Van Beek and Groenewoudt, 2011). The Overijsselse Vecht was an actively meandering river until 1896, when weirs were constructed and parts of the river were channelized. The river was completely channelized after $1914 \mathrm{CE}$, with five weirs controlling the water levels. Recently, sinuous side channels bypassing the weirs have been created as part of river restoration aiming to restore past physical and ecological characteristics of the river.

At present the topography of the meandering phase is partly still intact in the floodplain (Maas, 1995). Wolfert and Maas (2007) reconstructed the pre-channelization planform from historical maps of 1720,1850 and 1890 CE. Large differences in meander development and lateral migration rates were found between different river reaches. In particular in areas where non-cohesive aeolian sands formed the channel banks, large meanders formed and lateral migration reached rates up to $3 \mathrm{~m} \mathrm{yr}^{-1}$. In this research we will study two of the large meanders, named Prathoek and Junnerkoeland (Figure 4.1), where Quik and Wallinga (2018) reconstructed the scroll bar development using OSL dating in combination with historical maps.

Here we take advantage of the preservation of a palaeochannel (here referred to as "Palaeochannel X") with comparable dimensions as Palaeochannel Q (Huisink, 2000, p. 123), preserved in the Junnerkoeland as a sharp bend (Figure 4.1c). Maas (1995) interpreted Palaeochannel X to be connected to the oldest swale of the Junnerkoeland scroll bar deposits (Figure 4.1c). Palaeochannel X, however, was likely abandoned before the scroll bar formation, because large differences in dimensions exist between Palaeochannel $\mathrm{X}$ and the meander bend, but the well-preserved nature suggests that Palaeochannel $\mathrm{X}$ is relatively young. The small dimensions of both palaeochannels $\mathrm{X}$ and $\mathrm{Q}$ would suggest that the river had comparatively less energy, and may have been relatively laterally stable prior to the meandering phase. 


\subsection{Methods}

\subsubsection{Lithological description}

Cores were performed in a transect perpendicular to the scroll bars of both meander bends (Figure 4.1c-d). An additional transect was cored perpendicular to Palaeochannel $\mathrm{X}$ (Figure 4.1e). In case the deposit consisted of peat we used a gouge auger $(\varnothing: 3 \mathrm{~cm})$, in case of unsaturated sand we used an Edelman auger, and in case of saturated sand we used a Van der Staay suction corer (Van de Meene et al., 1979). In total, 68 cores were performed to a maximum depth of $7.3 \mathrm{~m}$. The surface elevation of each coring site was either determined using a GPS combined with a DEM (Van Heerd and Van't Zand, 1999), or with a Global Navigation Satellite System (GNSS) device. A standard method was used to describe the sediment cores in 10-cm-thick intervals, using the Dutch texture classification scheme, which approximately matches the USDA terminology (De Bakker and Schelling, 1966; Berendsen and Stouthamer, 2001). The median sediment grain size $\left(\mathrm{D}_{50}, \mathrm{~m}\right)$ of non-organic, sandy samples was visually checked in the field by comparison with a sand ruler. Grain size analysis was used to estimate a $\mathrm{D}_{50}$ for the entire scroll bar deposit (Sect. 4.3.3). In addition, the plant macro-remains, any visible bedding, and colour were described. The percentage of gravel $(>2 \mathrm{~mm})$ was estimated in the field using sieves. The lithogenesis was inferred from the lithological properties, facies geometries, and DEM topography, distinguishing fluvial, fluvioperiglacial, coversand, drift-sand, and residual channel-fill deposits (Ter Wee, 1966; Huisink, 2000).

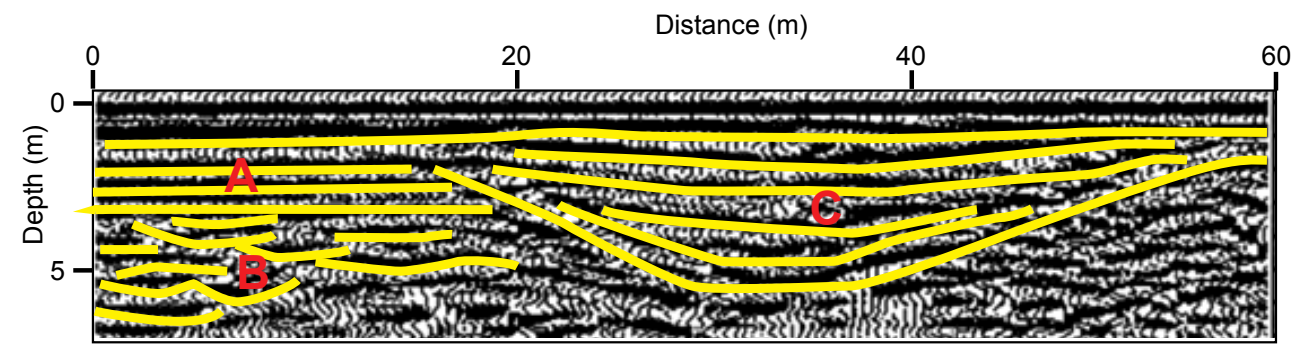

Figure 4.2 Interpretation by Huisink (2000) of subsurface strata from GPR data collected near Hardenberg $13 \mathrm{~km}$ upstream of Junnerkoeland (see location in Figure 4.1b). Horizontal strata of coversand deposits (A) on top of the channel deposits of an interpreted braiding system (B). A relatively small, symmetrical palaeochannel is present (C) within the Late-Glacial deposits, hereafter referred to as "Palaeochannel Q". Figure adapted after Huisink (2000). 


\subsubsection{Ground-penetrating radar}

Ground-penetrating radar (GPR) was used to reconstruct the channel dimensions of the scroll bars. GPR measurements were conducted with a pulseEKKO PRO $250 \mathrm{~Hz}$ with a SmartTow configuration. The GPR transects were placed along the centreline of the meander bends, perpendicular to the ridge and swale morphology (Figure 4.1c-d). The electromagnetic-wave velocity was $0.060 \mathrm{~m} \mathrm{~ns}^{-1}$, derived by using isolated reflector points (Van Heteren et al., 1998; Neal, 2004) and by comparing depths of recognizable layers with the coring data.

\subsubsection{Grain size analysis}

In total 33 samples for grain size analysis were taken from the scroll bar deposits and three samples were taken from Palaeochannel X. The samples of the scroll bar deposits were taken from each $0.5 \mathrm{~m}$ interval from the channel lag up to the swale surface at three locations in Junnerkoeland and two locations in Prathoek (Figure 4.1c-e). The samples of Palaeochannel $\mathrm{X}$ were taken from three locations below the residual channel-fill, from the former river bed. Grain size samples were analysed in a laboratory with a Beckman Coulter LS230 Laser Particle Sizer. This instrument has a measurement range of 0.1 to $2000 \mu \mathrm{m}$. Samples were sieved with a $2 \mathrm{~mm}$ sieve, and prepared with $\mathrm{HCl}(1 \mathrm{M})$ and $\mathrm{H}_{2} \mathrm{O}_{2}(30 \%)$. All data were processed using a Fraunhofer.rfd optical model, because of the low clay-silt content (Agrawal et al., 1991). Finally, the average and standard deviation were calculated for both the scroll bar deposits and Palaeochannel X, and used in the palaeohydrological calculations.

\subsubsection{OSL dating}

We used the modelled age-distance relationships determined by Quik and Wallinga (2018) in our calculations. Their obtained OSL ages from the scroll bar deposits were used as priors and combined with historical map data in a Bayesian sequence model using the OxCal software (Bronk Ramsey, 2009). For details on the method see Quik and Wallinga (2018). In this study, we took four additional samples for OSL dating on the inner and outer bank of Palaeochannel X. These samples were collected in an opaque PVC-tube $(\varnothing 4.5 \mathrm{~cm})$ mounted on a hand-auger allowing sampling without light exposure. The analysis in the laboratory followed the same procedure as in Quik and Wallinga (2018). The OSL age was determined at the Netherlands Centre for Luminescence dating, with equivalent doses measured on small aliquots of quartz using the SAR protocol (Murray and Wintle, 2003) and dose rates determined from activity concentrations measured using gamma-ray spectrometry. A bootstrapped version of the minimum age model (Cunningham and Wallinga, 2012) was used to derive the best estimate of the burial dose and deposition age. Given the limited amount of samples 
associated with Palaeochannel X, and absence of additional age constraints from historical maps, no Bayesian analysis was performed for these samples.

\subsection{5 ${ }^{14} \mathrm{C}$ dating}

A sample was taken in the deepest part of Palaeochannel $\mathrm{X}$, at the sand-peat interface, using a piston corer $(\varnothing: 6 \mathrm{~cm})$. Macro-remains and leaf fragments from terrestrial species were selected from $1 \mathrm{~cm}$ intervals in the laboratory using a light microscope. Samples were stored in diluted $\mathrm{HCl}(4 \%)$ at $5{ }^{\circ} \mathrm{C}$. The sand content was measured for each interval to precisely determine the position of the sand-peat interface. Material with volumetric sand percentages lower than 10 to $20 \%$ was considered as peat (Bos et al., 2012). The macro-remains from the centimetre above this interface were selected for the ${ }^{14} \mathrm{C}$ analysis providing a terminus ante quem date for the abandonment of the channel. The ${ }^{14} \mathrm{C}$ age was determined by Accelerator Mass Spectrometry (AMS) at the Centre for Isotope Research (Groningen University). For calibration, the IntCal13 curve was used in the OxCal 4.2.4 software (Bronk Ramsey, 2009; Reimer et al., 2013).

\subsubsection{Channel dimensions}

The channel dimensions of Palaeochannel $\mathrm{X}$ were determined from the lithological cross-section. The residual channel-fill was delineated along the sand-peat interface. Bankfull depth $\left(\mathrm{H}_{\mathrm{bf}}\right)$ was defined from the bottom of the palaeochannel up to the first clear knick-point on the bank, which was mapped with a GNSS device, such that the width-depth ratio was minimal (Williams, 1986). Relative error of $\mathrm{H}_{\mathrm{bf}}$ was assumed to be similar to the relative error of $\mathrm{H}_{\mathrm{bf}}$ during the meandering phase (ca. $\left.10 \%\right)$ and used in the calculations (see details below), because both $\mathrm{H}_{\mathrm{bf}}$ 's were determined by using coring data. Additional dimensions were measured from the delineated channel, involving the bankfull width (W), cross-sectional area $(\mathrm{A})$ and wetted perimeter $(\mathrm{P})$. These channel dimensions were also measured for Palaeochannel Q from the GPR profile recorded by Huisink (2000, p.123) (Figure 4.2). Here we assumed a similar relative error of W, A and $\mathrm{P}$ as was taken for $\mathrm{H}_{\mathrm{bf}}$

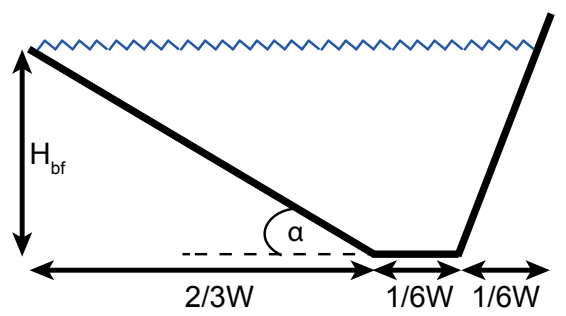

Figure 4.3 Sketch of the cross-sectional flow area of a meandering channel used for the bankfull palaeodischarge calculations (Allen, 1965; Leeder, 1973; Hobo, 2015). 
The river channel was assumed to have the channel dimensions as shown in Figure 4.3 during the meandering phase. This sketch is based on Allen (1965), Leeder (1973) and Hobo (2015). The bankfull depth $\left(\mathrm{H}_{\mathrm{bf}}\right)$ was estimated from the coring data, taken from the bottom of the channel lag up to the surface elevation in the swales (Figure 4.4). Small elevation differences were expected to result from local variation rather than real changes in $\mathrm{H}_{\mathrm{bp}}$ therefore the average $\mathrm{H}_{\mathrm{bf}}$ was calculated from the smoothed bottom and surface elevation. The standard deviation of $\mathrm{H}_{\mathrm{bf}}$ was calculated from the actual variable bottom elevation over the length of the scroll bar. The transverse bed slope $(\alpha)$ of the inner bend was determined based on the GPR transects (Figure 4.5), in which lateral accretion surfaces could be distinguished. The angle was measured on the steepest (middle) parts of the identified lateral accretion surfaces. The average and standard deviation of $\alpha$ were calculated and used in the calculations. The calculations of the channel dimensions follow from Figure 4.3. The bankfull width (W, $\mathrm{m})$ and cross-sectional area $\left(\mathrm{A}, \mathrm{m}^{2}\right)$ were determined by Eqs. 4.1 and 4.2:

$W=1.5 \frac{H_{b f}}{\tan (\alpha)}$

$A=W H_{\text {avg }}$

where $\mathrm{H}_{\mathrm{bf}}$ is the bankfull depth (m), and $H_{a v g}=\frac{7 H_{b f}}{12}$ and approximates the average water depth $(\mathrm{m})$. The wetted perimeter $(\mathrm{P}, \mathrm{m})$ was calculated from the assumed channel geometry (Figure 4.3) following Eq. 4.3:

$P=\frac{H_{b f}}{\sin (\alpha)}+\frac{W}{6}+\sqrt{H_{b f}^{2}+\left(\frac{W}{6}\right)^{2}}$

The hydraulic radius $(\mathrm{R}, \mathrm{m})$ was calculated by Eq. 4.4:

$R=\frac{A}{P}$

For each swale visible on the DEM the sinuosity $(s,-)$, radius of curvature $\left(R_{\text {curv }}, m\right)$ and scroll bar surface area $\left(\mathrm{SB}_{\text {surf }} \mathrm{m}^{2}\right)$ was measured. The former channel sinuosity was estimated by the use of the DEM, measuring the distance along the swales relative to the distance along the valley between the inflection points (Figure 4.1c-d). The sinuosity of Palaeochannel $\mathrm{X}$ was measured using the same approach (Figure 4.1c). The channel slope $\left(S_{c},-\right)$ was calculated from the sinuosity and valley slope $\left(S_{v},-\right)$ determined by TAUW (1992) and Wolfert and Maas (2007) following Eq. 4.5:

$S_{c}=S_{v} / s$ 
The volumetric rate of scroll bar growth $\left(\mathrm{SB}_{\mathrm{vol}}, \mathrm{m}^{3} \mathrm{yr}^{-1}\right)$ was determined from scroll bar surface area $\left(\mathrm{SB}_{\text {surf }}, \mathrm{m}^{2} \mathrm{yr}^{-1}\right)$ and thickness between each swale and interpolated time interval following Eq. 4.6:

$S B_{\text {vol }}=\frac{S B_{\text {surf }} * H_{b f} *(1-\varphi)}{\Delta a g e}$

where $\varphi$ is the porosity (here 0.3 to 0.35 volume fraction) (Nimmo, 2004), which was included to compare the $\mathrm{SB}_{\text {vol }}$ with the sediment transport, and $\triangle$ age is the age difference between the scroll bars (yr) based on the datings by Quik and Wallinga (2018). Although scroll bar deposits were absent, following Eq. 4.6 we also calculated the volumetric sediment transport for the fluvial deposits on the inside of Palaeochannel X.

\subsubsection{Palaeodischarge}

The channel dimensions were used to calculate the bankfull discharge $\left(\mathrm{Q}_{\mathrm{bp}}, \mathrm{m}^{3} \mathrm{~s}^{-1}\right)$. Bankfull discharge $\left(\mathrm{Q}_{\mathrm{bf}}\right)$ is commonly considered an approximation of the channelforming discharge with a recurrence interval of 1 to 2 years (Wolman and Miller, 1960; Dury, 1973). We assumed that the bankfull discharge was similar for both Junnerkoeland and Prathoek, regarding the short distance between these river sections (Figure 4.1b). Hence the bankfull discharge was presented by combining the bankfull discharges for both meander bends. The bankfull discharge was estimated by applying the Chézy equation, following Eq. 4.7:

$Q_{b f}=C A \sqrt{R S_{c}}$

where $\mathrm{Q}_{\mathrm{bf}}$ is the bankfull discharge $\left(\mathrm{m}^{3} \mathrm{~s}^{-1}\right)$, and $\mathrm{C}$ is the Chézy coefficient $\left(\mathrm{m}^{0.5} \mathrm{~s}^{-1}\right)$. The Chézy coefficient, i.e. flow resistance, was estimated by substituting Eq. 4.8 in Eq. 4.7. Equation 4.8 is an empirical relation (Brownlie, 1983):

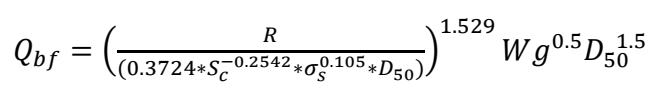

where $\sigma_{s}$ is the sorting of the bed material grain size $(-)$ derived from the grain size analysis (Sect. 4.3.3) and approximated by $0.5\left(\frac{D_{50}}{D_{16}}+\frac{D_{84}}{D_{50}}\right), \mathrm{D}_{16}$ and $\mathrm{D}_{84}$ are the $16^{\text {th }}$ and $84^{\text {th }}$ percentile sediment grain size $(\mathrm{m})$, respectively, and $\mathrm{g}$ is the gravitational acceleration $\left(\mathrm{m}^{2} \mathrm{~s}^{-1}\right)$. As a validation, the calculated Chézy coefficient was compared with average Chézy coefficients of 12 comparable low-energy, sand-bed rivers with scroll bars $\left(\mathrm{S}_{\mathrm{v}}<0.001,90<\mathrm{Q}_{\mathrm{bf}}<320 \mathrm{~m}^{3} \mathrm{~s}^{-1}\right)$, calculated from a large river dataset (Van den Berg, 1995; Kleinhans and Van den Berg, 2011). The cross-sectional averaged flow velocity $\left(\mathrm{u}_{\mathrm{b} \rho} \mathrm{m} \mathrm{s}^{-1}\right)$ was calculated by following Eq. 4.9: 
$u_{b f}=\frac{Q_{b f}}{A}$

\subsubsection{Sediment transport}

The sediment transport was calculated to compare with the $\mathrm{SB}_{\text {vol }}$ (Eq. 4.6). Sediment transport was calculated in two different ways. The first method was the slightly modified Engelund and Hansen (1967) relation following Eq. 4.10:

$Q_{S, b f}=\frac{0.05 u^{5} W t i}{\left(\frac{\rho S}{\rho}-1\right)^{2} g^{0.5} D_{50} C^{3}(1-\varphi)}$

where $\mathrm{Q}_{\mathrm{s}, \mathrm{b}}$ is the yearly sediment transport derived from the bankfull discharge $\left(\mathrm{m}^{3} \mathrm{yr}^{-1}\right)$, $t$ is the number of seconds in a year, $i$ is the intermittency assumed to be 0.03 to 0.07 (Parker, 2008), $\rho_{\mathrm{s}}$ is the sediment density $\left(\mathrm{kg} \mathrm{m}^{-3}\right), \rho$ is the water density $\left(\mathrm{kg} \mathrm{m}^{-3}\right), \varphi$ is the porosity assumed to be 0.3 to 0.35 (Nimmo, 2004). The relation of Engelund \& Hansen was used, because the relation is suitable for sand-bed rivers with relatively low flow velocities (Van den Berg \& Van Gelder, 1993), and the input variables required were available.

In the second method the sediment transport was determined for each discharge magnitude and related frequency $\left(\mathrm{Q}_{\mathrm{s} \text {,freq }}\right)$ (Wolman and Miller, 1960) from presentday flow conditions, by assuming that the current discharge frequency distribution also applied to the meandering phase. We used the hourly discharge data from 1995 to 2015 of the gauging station in Mariënberg (Figure 4.1b). This gauging station is close to the study location, and has the lowest amount of data gaps compared to the other stations. The flow duration was calculated for intervals of $10 \mathrm{~m}^{3} \mathrm{~s}^{-1}$, and for each discharge interval the sediment transport was calculated using Eq. 4.10, excluding the intermittency factor. When the discharge would be above bankfull, the flow would go across the floodplain. The Chézy coefficient for the floodplain was assumed to be half the Chézy coefficient in the channel, because of the higher roughness of the floodplain compared to the channel. We assumed that the floodplain width was $350 \mathrm{~m}$ for the start of the meandering phase, which was estimated from the DEM (Figure 4.1c), and that the width would increase proportionally with the lateral migration rate for each time step during the meandering phase. 


\subsubsection{Potential specific stream power}

The potential specific stream power was calculated to plot into a stability diagram. Kleinhans and Van den Berg (2011) distinguished four different stability fields, further building on Van den Berg (1995) and Makaske et al. (2009): rivers with laterally stable channels, meandering rivers with scroll bars, meandering rivers with scroll and chute bars as well as moderately braided rivers, and braided rivers. In this research, only the first two stability fields are relevant. These stability fields are separated by a discriminator that represents the theoretical minimum energy needed for the channel pattern to occur (Kleinhans and Van den Berg, 2011). The potential specific stream power was calculated by applying the relationship presented by Kleinhans and Van den Berg (2011) following Eq. 4.11:

$\omega_{p v}=\frac{\rho g \sqrt{Q_{b f}} S_{v}}{\varepsilon}$

where $\omega_{p v}$ is the potential specific stream power $\left(\mathrm{W} \mathrm{m}^{-2}\right), \varepsilon=4.7 \sqrt{s}_{s} m^{-1}$ for sand-bed rivers (Van den Berg, 1995). The discriminator line was plotted applying the relationships presented by Makaske et al. (2009) and Kleinhans and Van den Berg (2011) following Eq. 4.12:

$\omega_{i a}=90 D_{50}^{0.42}$

where subscript $i a$ refers to the discrimination between laterally stable and meandering channels with scroll bars.

\subsubsection{Bar regime}

Bar regime was predicted applying the relationships of Struiksma et al. (1985) and Kleinhans and Van den Berg (2011). River bends can be seen as an example of a perturbation to both the flow and bed sediment, which have different adaptation lengths over which they return to equilibrium. This difference in response is expressed by the interaction parameter (IP), which is the ratio between the adaptation length of bed perturbation and the adaptation length of flow. The adaptation length of flow was calculated following Eq. 4.13:

$\lambda_{w}=\frac{C^{2} H_{a v g}}{2 g}$

and the adaptation length of a bed perturbation $(\mathrm{m})$ is calculated following Eq. 4.14:

$\lambda_{S}=\frac{H_{\text {avg }}}{\pi^{2}}\left(\frac{W}{H_{\text {avg }}}\right)^{2} f(\theta)$ 
where $f(\theta)$ is the magnitude of the transverse slope effect $(-)$ calculated following Eq. 4.15 (Talmon et al., 1995):

$f(\theta)=9\left(\frac{D_{50}}{H_{\text {avg }}}\right)^{0.3} \sqrt{\theta}$

where $\theta$ is the dimensionless shear stress (-) calculated following Eq. 4.16:

$\theta=\frac{\tau}{\left(\rho_{s}-\rho\right) g D_{50}}$

where $\tau$ is the shear stress $(\mathrm{Pa})$, calculated following Eq. 4.17:

$\tau=\rho g R S_{c}$

The interaction parameter (IP, -) was calculated, following Eq. 4.18, to determine the bar regime for the historical and prehistorical Overijsselse Vecht, and for comparison with the theoretical thresholds of bar regime (Struiksma et al., 1985; Crosato and Mosselman, 2009) by:

$I P=\frac{\lambda_{s}}{\lambda_{w}}$

The IP is strongly related to the width-depth ratio, and was therefore separately calculated for the meander bends Junnerkoeland and Prathoek. A low IP means that when a bar forms in response to a local perturbation, such as local curvature, the bar disappears within a short distance of the perturbation (Struiksma et al., 1985). This is called an overdamped regime and occurs in channels with a low width-depth ratio. The threshold threshold between overdamped and underdamped can be calculated following Eq. 4.19:

$I P \leq \frac{2}{n+1+2 \sqrt{2 n-2}}$

where $\mathrm{n}$ is the degree of nonlinearity of sediment transport versus depth-averaged flow velocity (-). Following Crosato and Mosselman (2009) we chose $n=4$, which corresponds to values for a sand-bed river. A higher IP, and hence a higher width-depth ratio, results in an underdamped regime associated with bars that also form further downstream of the perturbation. The thresholds can be calculated following Eq. 4.20:

$\frac{2}{n+1+2 \sqrt{2 n-2}}<I P<\frac{2}{n-3}$ 


\subsubsection{Errors and uncertainty}

The above described calculations (Eqs. 4.1 to 4.11 , and 4.13 to 4.20 ) were run 10,000 times to take into account the random errors of the input parameters, following a stochastic approach by using Monte Carlo simulations. The uncertainty of these parameters was described above, relating to the transverse bed slope, bankfull depth of the meanders, valley slope, porosity, grain size, intermittency and the measured channel dimensions of palaeochannels X and Q. Systematic errors were not taken into account, because the palaeohydrological reconstruction was meant to distinguish relative differences between fluvial phases, rather than reconstructing absolute hydrological parameters. Results are plotted with average values from the Monte Carlo simulations when normally distributed, or median values when not-normally distributed, including the $16^{\text {th }}$ and $84^{\text {th }}$ quantile representing the uncertainty margin. All used formulas and example data are made available in the Supplementary Information by Candel et al. (2018b).

\subsection{Results}

\subsubsection{Lithogenetic units}

Several lithogenetic units were distinguished (Figure 4.4), following similar interpretations of the sedimentary units as Huisink (2000). The descriptions of the lithogenetic units are summarized in Table 4.1. The coversand deposits were sometimes difficult to distinguish in borehole descriptions from the fluvioperiglacial deposits, when the latter has a relatively fine grain size. Because our interest is in the delineation of the scroll bar and residual channel-fill deposits, we combined both the fluvioperiglacial and coversand deposits into one unit. The fining upward sequence within the scroll bar deposits (Table 4.1) can be recognized in the grain size analysis done for the scroll bar deposits at Junnerkoeland and Prathoek (Figure 4.6). The depth-averaged grain size for both scroll bar complexes is $0.28 \pm 0.05 \mathrm{~mm}$. Commonly, at the base of the scroll bar deposits, a sharp transition occurs to the brightly coloured substratum of fluvioperiglacial deposits below, which lack organic material (Table 4.1). Cores that did not reach the fluvioperiglacial deposits below the scroll bar deposits indirectly indicate the boundary between these units, because strongly consolidated layers are present in the fluvioperiglacial deposits that were difficult to core into. An example of a consolidated clay layer can be found directly below the southern part of the scroll bar deposits at Prathoek (Figure 4.4b). 

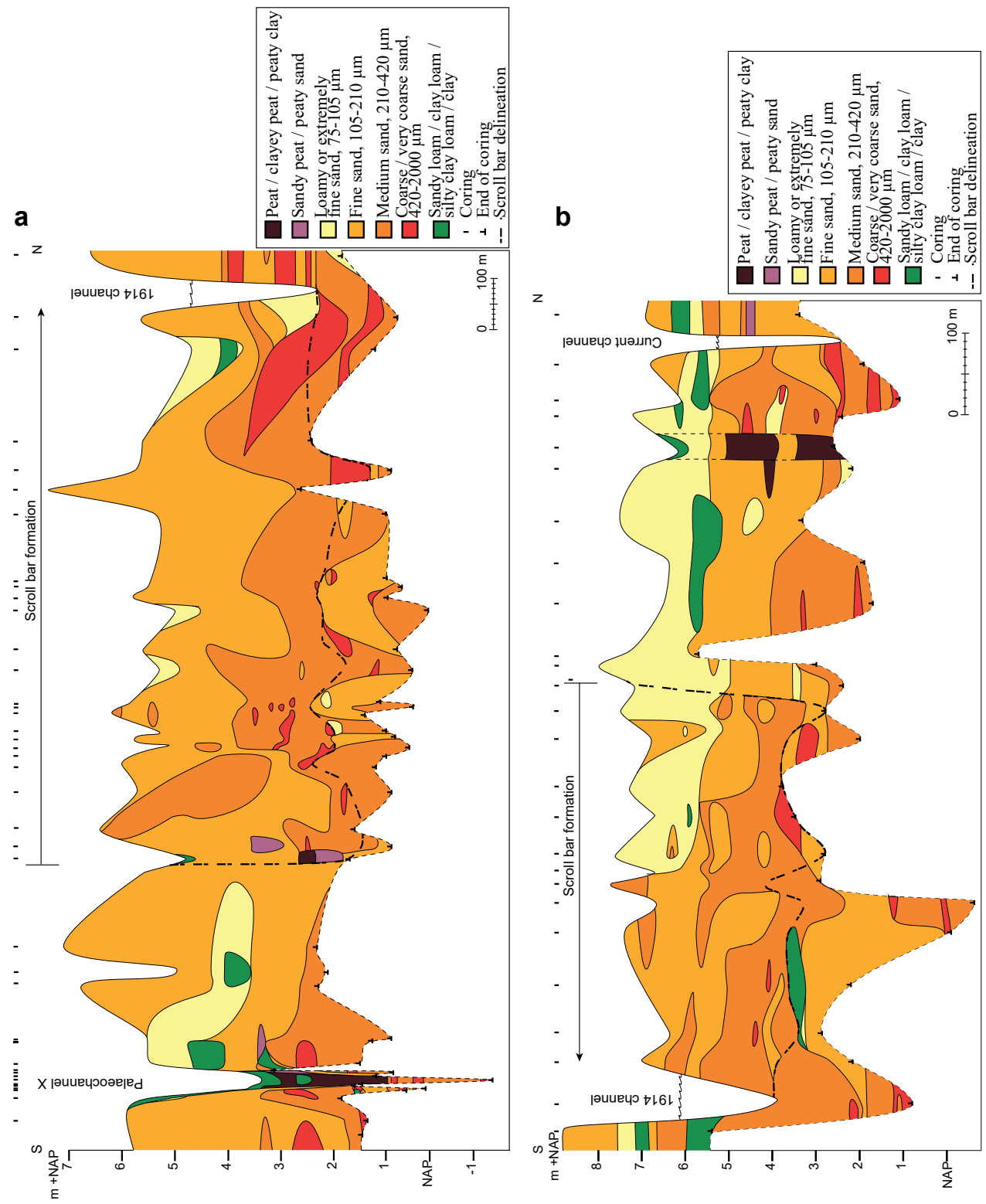


\section{Chapter 4}

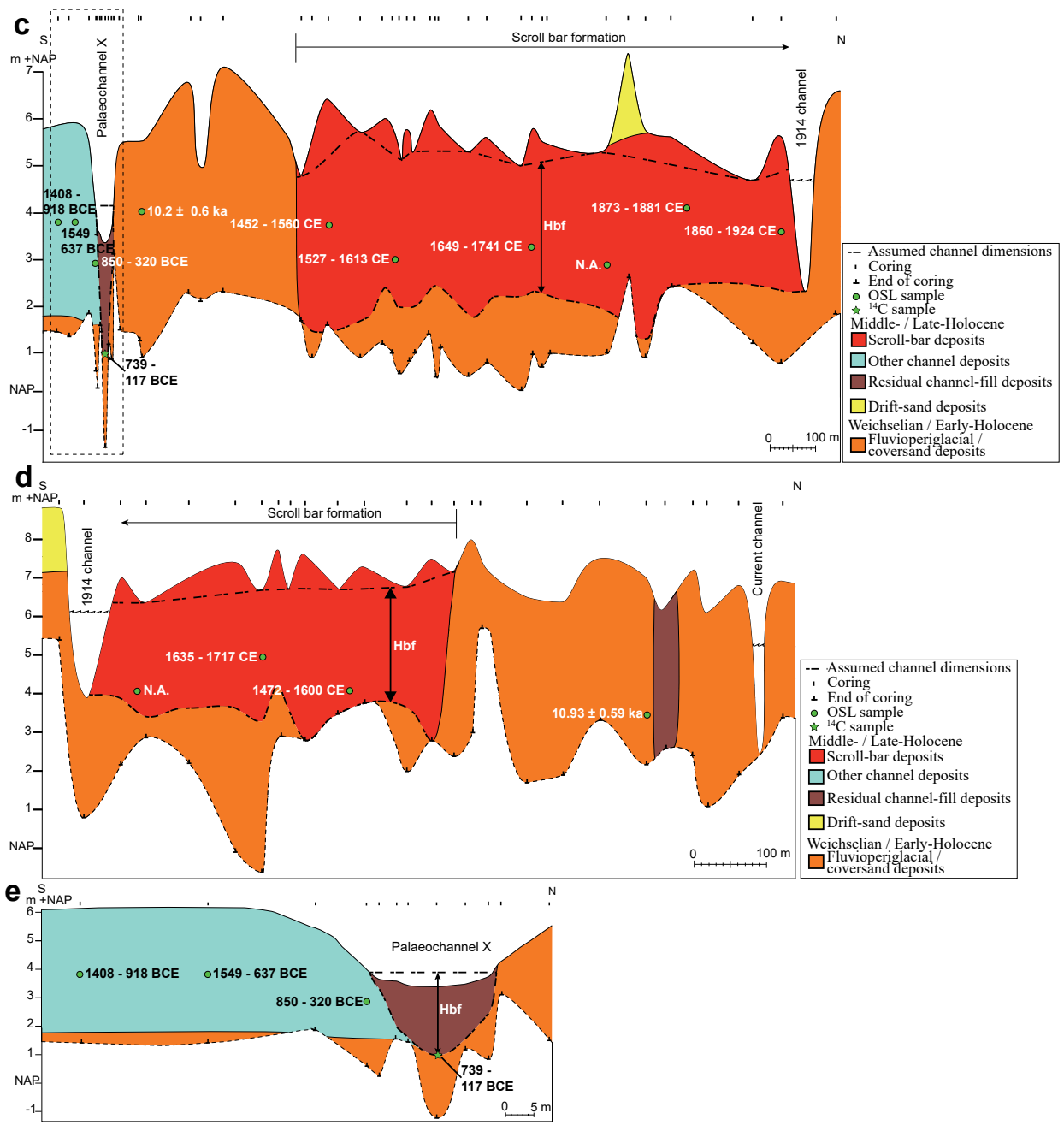

Figure 4.4 Stratigraphic cross-sections of the study sites (for location see Figure 4.1). Lithological crosssections of Junnerkoeland (a) and Prathoek (b). Lithogenetic cross-sections of Junnerkoeland (c) and Prathoek (d) including the OSL samples by Quik and Wallinga (2018) and OSL and ${ }^{14} \mathrm{C}$ dating results from this study. The surface and erosive base elevation are indicated with dashed lines, resulting in the inferred bankfull channel depth $\left(\mathrm{H}_{\mathrm{bf}}\right)$. (e) Zoomed-in lithogenetic cross-section of Palaeochannel X. The thick dashed line indicates the bankfull level of the palaeochannel. 
a

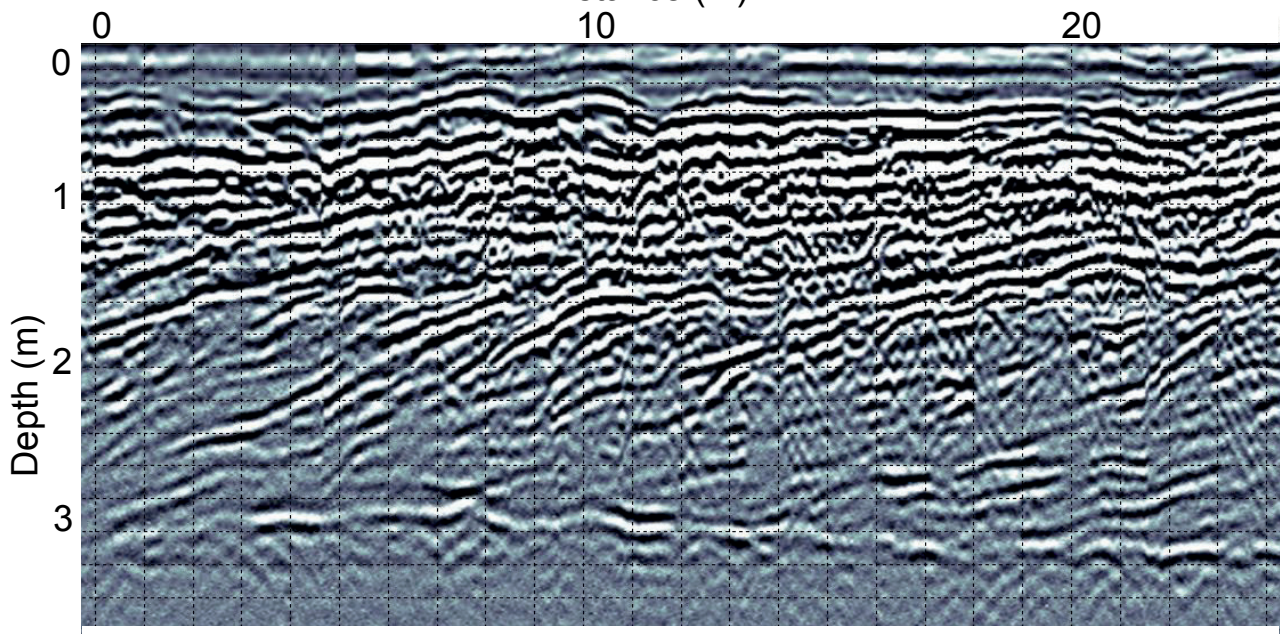

b

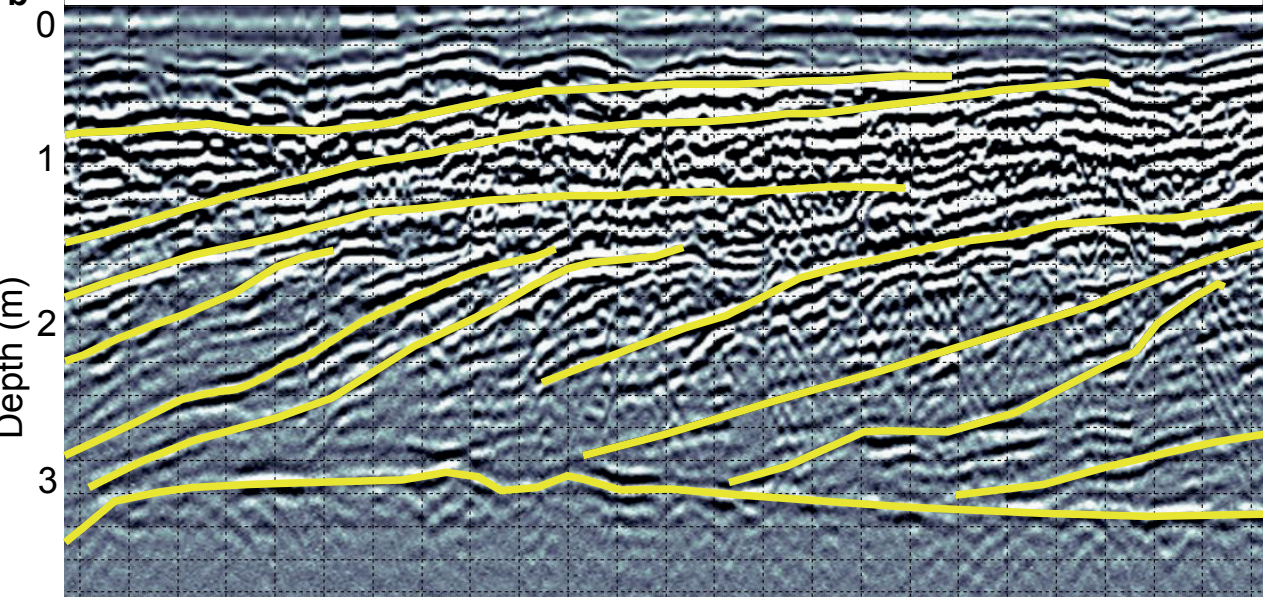

Figure 4.5 Example of a ground-penetrating radar (GPR) profile $(250 \mathrm{~Hz})$ in the Prathoek bend. (a) Original GPR profile and (b) interpreted GPR profile with lateral accretion surfaces and the channel lag, indicated by yellow lines. 


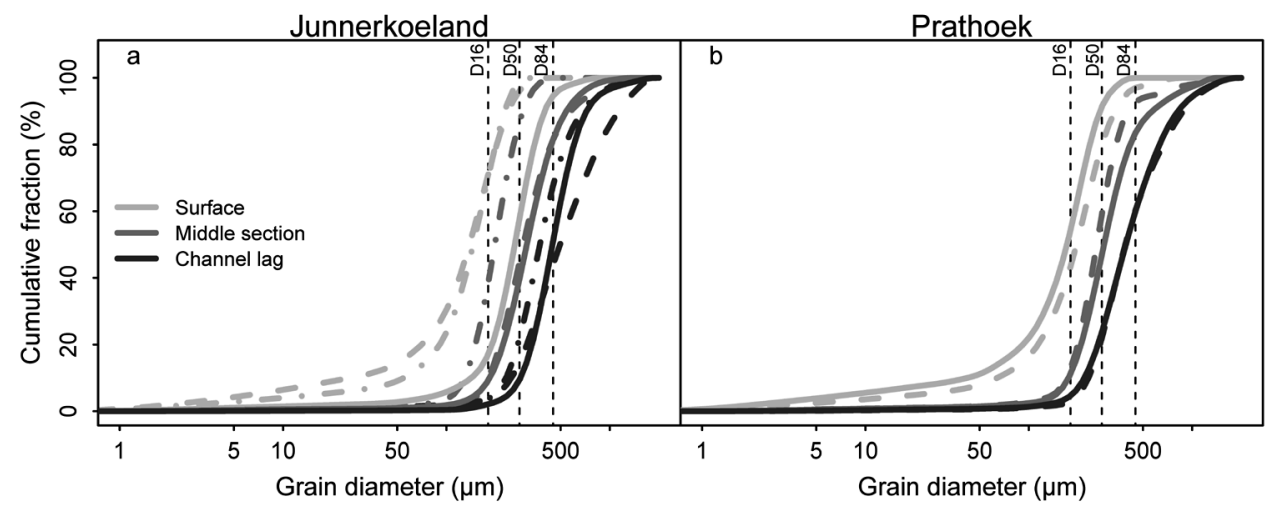

Figure 4.6 Cumulative grain size distributions of the scroll bar deposits in (a) Junnerkoeland and (b) Prathoek. Three series were made for Junnerkoeland and two for Prathoek, each indicated by a different line type. Each sample within a series is indicated by a different grey tone. The averages of $\mathrm{D}_{16}, \mathrm{D}_{50}$ and $\mathrm{D}_{84}$ are plotted. Figure $4.1 \mathrm{c}-\mathrm{d}$ indicates the locations of the grain size samples.

The GPR profiles clearly show the lateral accretion surfaces of the scroll bar deposits (see example in Figure 4.5). Only where the scroll bar deposits are relatively loamy or clayey on top, the GPR results were poor (i.e. northern parts of Prathoek and Junnerkoeland). The bottom of the scroll bar deposits is mostly unrecognizable, because of a low GPR reflection at this depth. In Figure 4.5 the bottom of the scroll bars is visible, because this part is located in the southern part of Prathoek where the above-mentioned clay layer was present (Figure 4.4), which caused a strong reflection of the GPR signal. The well-preserved Palaeochannel X is a relatively symmetrical palaeochannel (Figure 4.4e), similar to Palaeochannel Q of Huisink (2000) (Figure 4.2). The outer bank consists of Weichselian / Early Holocene deposits (Figure 4.4c). The average grain size of the Palaeochannel X bed sediments is $0.23 \pm 0.12 \mathrm{~mm}$. No lateral accretion surfaces can be observed in the GPR profile that was placed along the centreline of the Palaeochannel X bend (Figure 4.1e and Appendix 3).

\subsubsection{Dating results}

The channel deposits on the inside of the Palaeochannel X date from 850 - 320 BCE and $1408-918$ BCE. Palaeochannel X was cut off at $739-117$ BCE (Figures 4.1e and 4.4c,e, and Table 4.2). 
Late Holocene channel pattern change from laterally stable to meandering

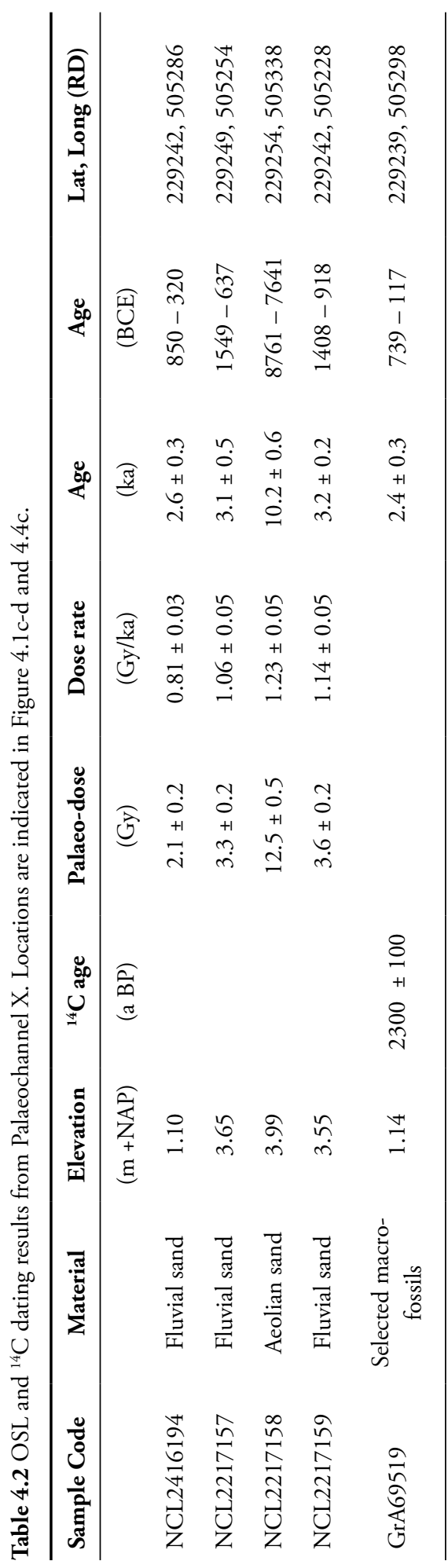




\subsubsection{Meander and channel geometry}

The reconstructed transverse bed slopes do not show a spatial trend (Figure 4.7a-b), hence the mean and standard deviations were used in the palaeohydrological calculations. The transverse bed slope at Prathoek is higher $\left(4.5 \pm 1.0^{\circ}\right)$ than at Junnerkoeland $\left(3.3 \pm 1.3^{\circ}\right)$, but much lower than the transverse bed slope of Palaeochannel X $\left(16.9 \pm 1.9^{\circ}\right)$ and of Palaeochannel Q $\left(28.8 \pm 3.8^{\circ}\right)$. The age as function of distance of lateral accretion follows from Figure $4.7 \mathrm{c}-\mathrm{d}$. This relation was used for the meander and channel geometry calculations (Figure 4.8). The bankfull depths of palaeochannels X and Q are comparable to the bankfull depths of the meanders Prathoek and Junnerkoeland ca. 1500 CE (Figure 4.8a-b) (3 to $4 \mathrm{~m}$ ). The bankfull depths at Junnerkoeland decreased relatively fast ca. $1800 \mathrm{CE}$, because the erosive base elevation rises towards the cut-off channel (Figure 4.4c). At Prathoek, the bankfull depth decreased more gradual with time. The reconstructed bankfull width of palaeochannels $\mathrm{X}$ and $\mathrm{Q}$ is much lower compared to the meandering phase (Figure $4.8 \mathrm{c}-\mathrm{d}$ ), resulting in a relatively small crosssectional area of palaeochannels X and Q (Figure 4.8e-f).

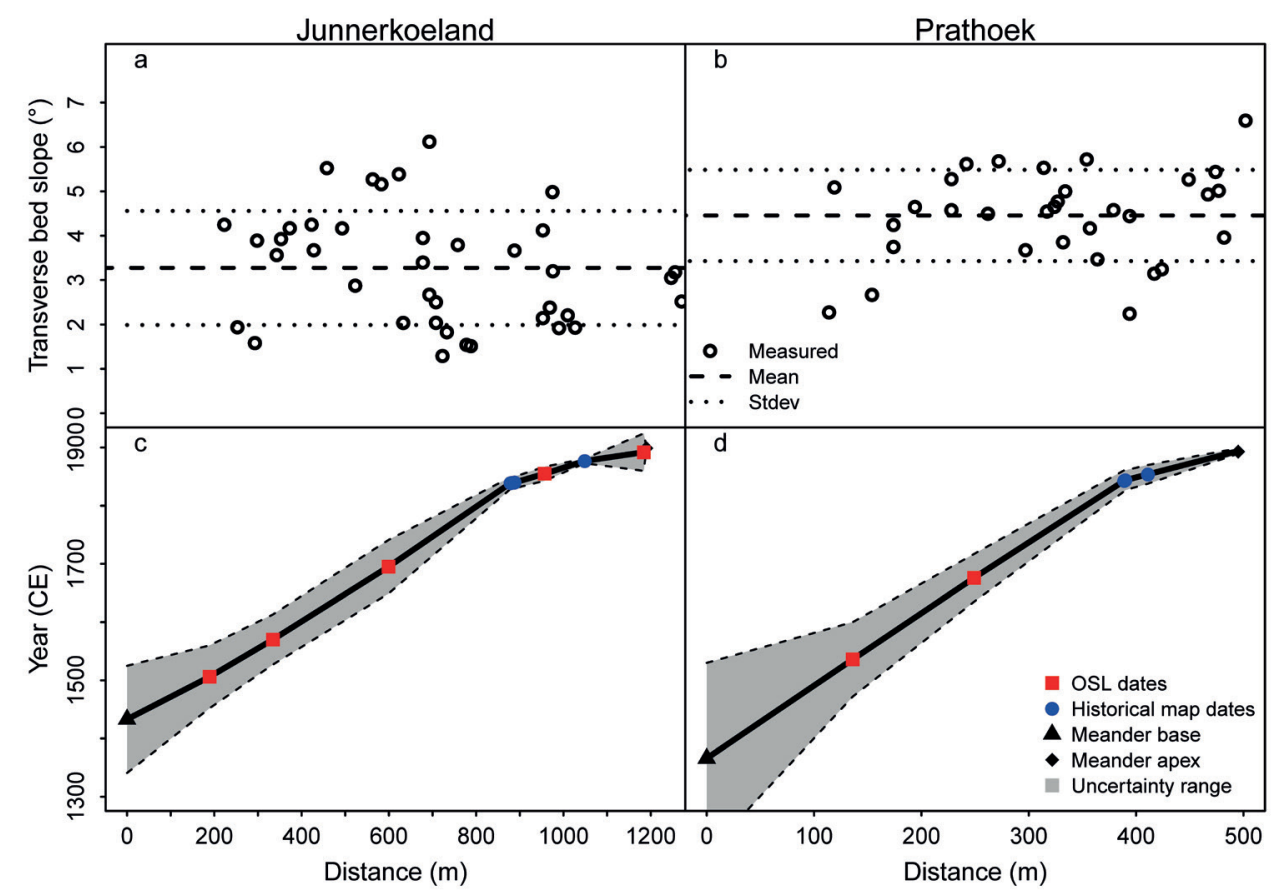

Figure 4.7 Transverse bed slope derived from GPR cross-sections from the inner point bar to the outer bend for Junnerkoeland (left) and Prathoek (right) as well as lateral migration distance plotted against age for both bends. Panels (a) and (b) show transverse bed slope of lateral accretion surfaces measured in the GPR profile (example in Figure 4), including the mean and standard deviation of all measurements. Panels (c) and (d) show the relation between age and migration distance of the bends. Shading indicates standard deviation of the Bayesian deposition model determined by Quik and Wallinga (2018) for the OSL and historical map dates. 


\subsubsection{Palaeohydrology}

The reconstructed $\mathrm{Q}_{\mathrm{bf}}$ is three to nine times higher at the start of the meandering phase $\left(85-194 \mathrm{~m}^{3} \mathrm{~s}^{-1}\right)$ compared to the preceding phase represented by palaeochannels $\mathrm{X}$ and $\mathrm{Q}\left(19-32 \mathrm{~m}^{3} \mathrm{~s}^{-1}\right)$ (Figure 4.9). The difference in $\mathrm{Q}_{\mathrm{bf}}$ between $400 \mathrm{BCE}$ and $1500 \mathrm{CE}$ is significant, despite the relatively large uncertainty. A similar discharge in $400 \mathrm{BCE}$ compared to $1500 \mathrm{CE}$ would require a cross-sectional area five times larger than currently estimated (Figure 4.8e), or a 50 times higher valley slope, which falls outside the uncertainty ranges of these parameters. The $\mathrm{Q}_{\mathrm{bf}}$ eventually declines over time, and drops to $32-70 \mathrm{~m}^{3} \mathrm{~s}^{-1} \mathrm{ca}$. $1850 \mathrm{CE}$. The calculated Chézy coefficients for the meandering phase $\left(47.5 \pm 0.9 \mathrm{~m}^{0.5} \mathrm{~s}^{-1}\right.$, Eqs. 4.7 and 4.8) were comparable to average Chézy coefficients derived from 12 low-energy rivers $\left(44.8 \pm 13 \mathrm{~m}^{0.5} \mathrm{~s}^{-1}\right)$ from the river dataset by Kleinhans and Van den Berg (2011). 


\section{Chapter 4}

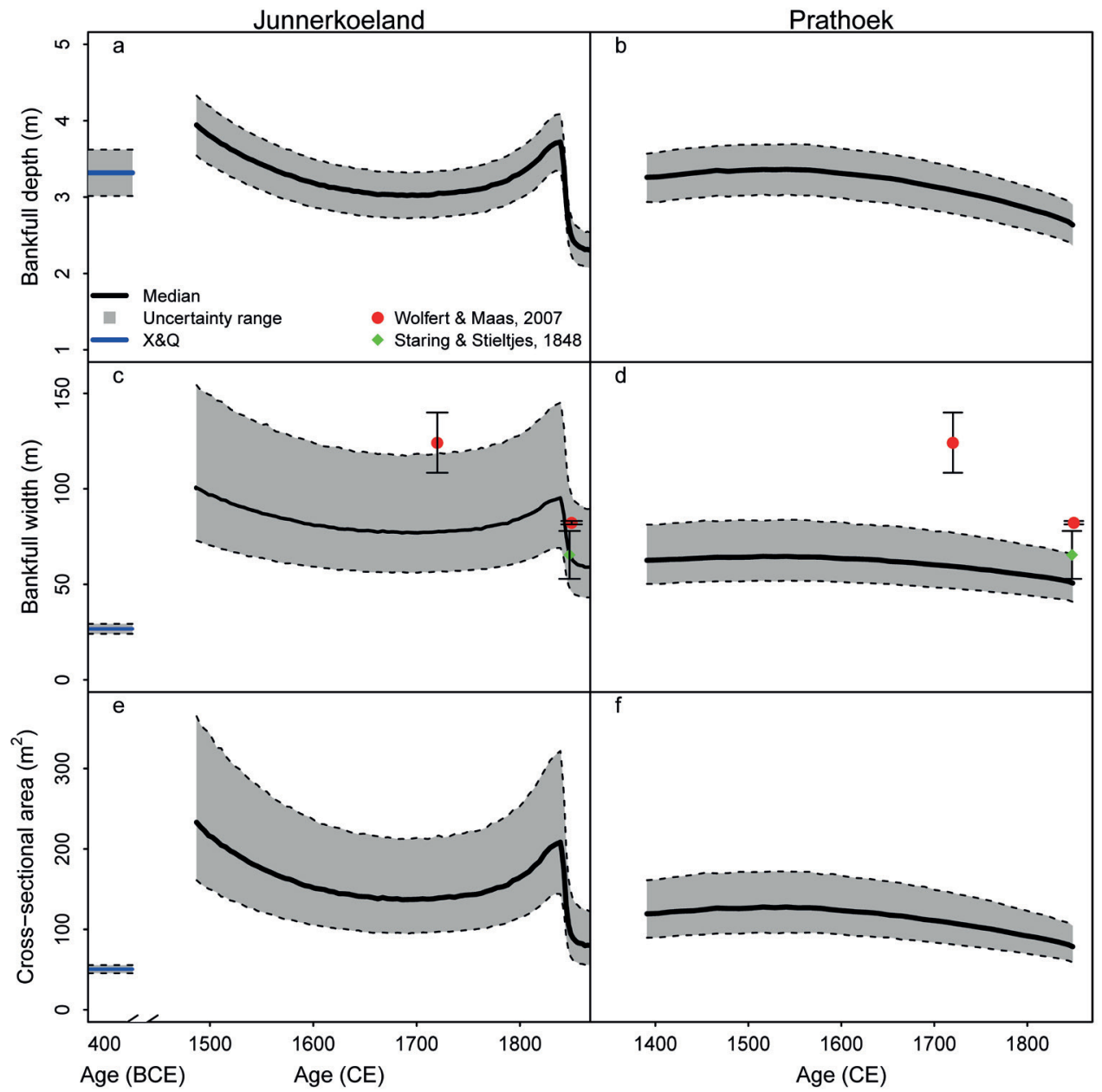

Figure 4.8 Reconstructed meander and channel geometry with time, assuming the date-distance relations (see Figure 4.7c-d) over the scroll bars. Panels (a) and (b) show the bankfull depth $\left(\mathrm{H}_{\mathrm{bf}}\right)$ derived from the coring data, taken from the bottom of the channel lag to the inferred bankfull water surface (Figure 4.4cd). Panels (c) and (d) show the bankfull width for both the Junnerkoeland bend (left) and Prathoek (right) derived from the bankfull depth and reconstructed transverse bed slope (Eq. 4.1). The river width data from Wolfert and Maas (2007) observed on historical maps, and the bankfull river width data from Staring and Stieltjes (1848) were included for comparison. Panels (e) and (f) show the cross-sectional area derived from the bankfull width and water depth (Eq. 4.2). Shading indicates the 16th and 84th quantile. X\&Q refers to palaeochannel X and Q. 
Combining the frequency of each discharge interval with the sediment transport rate (Figure 4.10a), results in a histogram of the sediment transport contribution as a function of discharge $\left(\mathrm{Q}_{\mathrm{s}, \text { freq }}\right.$, Figure $\left.4.10 \mathrm{~b}\right)$. The highest measured discharge at the gauging station Mariënberg between 1995 and 2015 is $185.5 \mathrm{~m}^{3} \mathrm{~s}^{-1}$. The most frequent discharge occurring in the channelized Overijsselse Vecht is 0 to $10 \mathrm{~m}^{3} \mathrm{~s}^{-1}$, with a frequency of $8.2 \%$ (Figure 4.10a). When discharge is still below bankfull, sediment transport increases relatively fast with an increasing discharge. Above bankfull, additional discharge largely flows across the more flow-resistant floodplain, and hence the sediment transport rates increase less. The effective discharge $\left(\mathrm{Q}_{\mathrm{eff}}\right)$ is $29 \mathrm{~m}^{3} \mathrm{~s}^{-1}$, represented by the highest sediment transport contribution (Figure 4.10a-b).

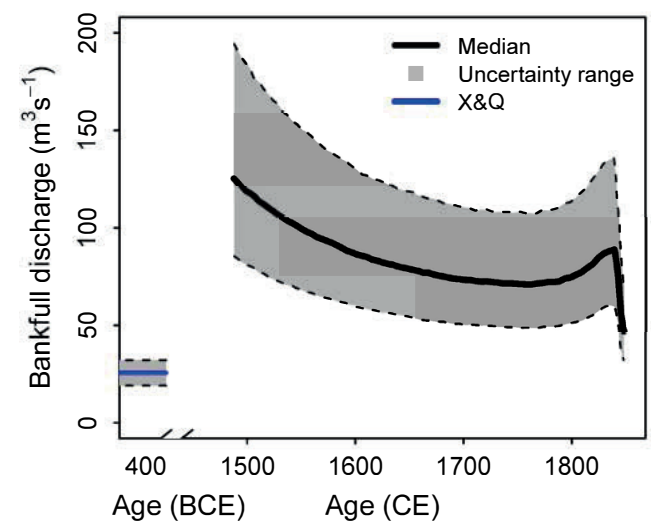

Figure 4.9 Bankfull discharge with time, combined for Junnerkoeland and Prathoek. Shading indicates the $16^{\text {th }}$ and $84^{\text {th }}$ quantile. X\&Q refers to palaeochannel X and Q.

Calculated sediment transport rates were higher than the inner bank growth or scroll bar growth, suggesting the channel deposition can be explained entirely by the reconstructed sediment transport (Figure 4.10c). The $\mathrm{Q}_{\mathrm{s}, \mathrm{bf}}$ of the laterally stable phase was much lower than for the meandering channels, explaining the large difference between the growth rate of the channel deposits on the inner bank at Palaeochannel X $\left(7.0 \mathrm{~m}^{3} \mathrm{yr}^{-1}\right)$ and the scroll bars of Junnerkoeland and Prathoek at the start of the meandering phase $\left(1.8^{*} 10^{3}\right.$ $\left.\mathrm{m}^{3} \mathrm{yr}^{-1}\right)$. Both the sediment transport and average scroll bar growth decreased during the meandering phase. 


\section{Chapter 4}
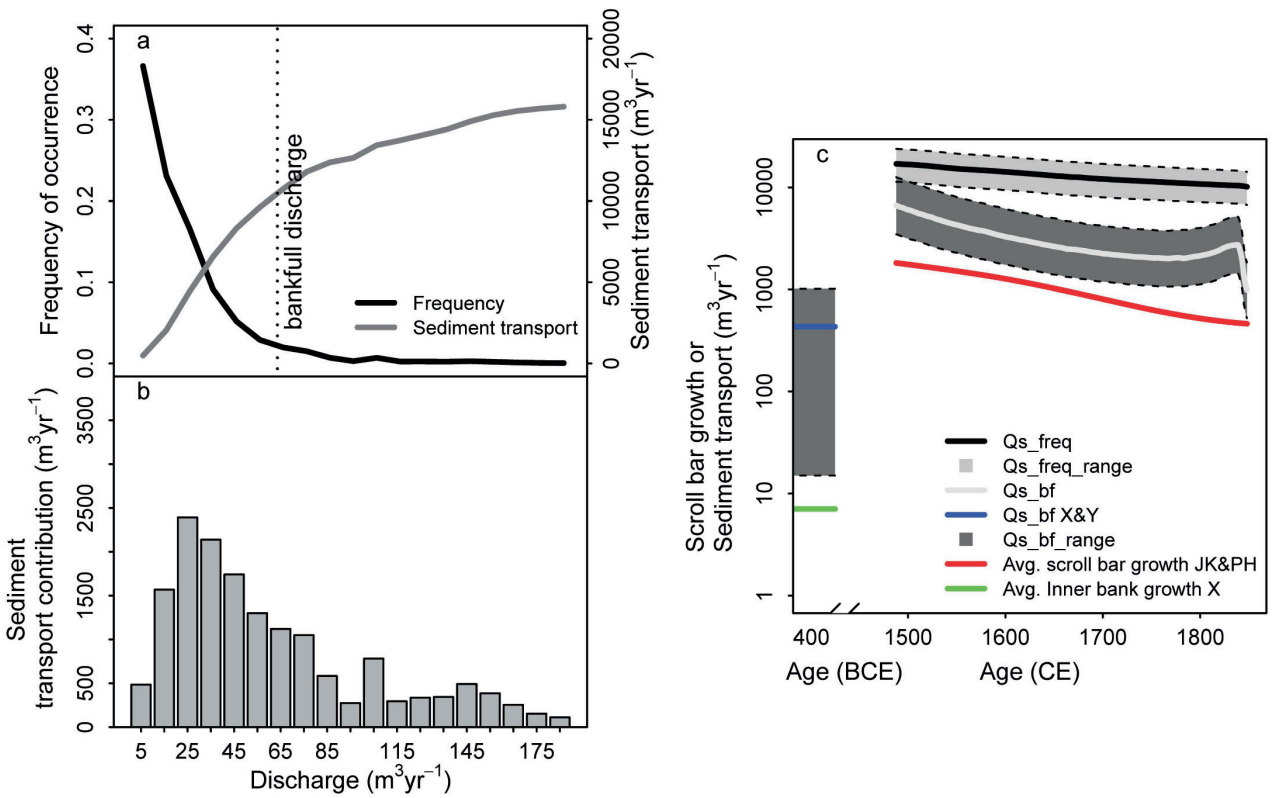

Figure 4.10 Sediment transport budgets calculated from present-day flow conditions and from meander migration. (a) Discharge and sediment transport characteristics of the Overijsselse Vecht derived from hourly discharge data from 1995 to 2015 of the gauging station Mariënberg, including the frequency of each discharge class over a year, on a frequency scale from 0 to 1 , and the sediment transport as function of discharge for a random selected year (1546 CE) in the Junnerkoeland meander bend. (b) Histogram of the sediment transport contribution as function of discharge. (c) The sediment transport and average scroll bar growth with time (JK = Junnerkoeland, $\mathrm{PH}=$ Prathoek, $\mathrm{X} \& \mathrm{Q}=$ Palaeochannel $\mathrm{X}$ and $\mathrm{Q}$ ). The abbreviations $\mathrm{Q}_{\text {s.feq }}$ and $\mathrm{Q}_{\mathrm{s}, \mathrm{ff}}$ are explained in Sect. 4.3.8. The inner bank growth $\mathrm{X}$ refers to the growth rate of the channel deposits on the inner bank at Palaeochannel X, assuming a constant lateral migration rate. Shading indicates the $16^{\text {th }}$ and $84^{\text {th }}$ quantile.

Figure 4.11a shows that the river theoretically had insufficient stream power for meandering ca. $400 \mathrm{BCE}$, and the bar regime was overdamped (Figure 4.11b). The stream power seemed sufficient for meandering ca. $1500 \mathrm{CE}$, and the bar regime was underdamped. The potential for meandering gradually decreased during the meandering phase, and became again insufficient when the potential specific stream power drops relatively fast ca. $1850 \mathrm{CE}$. The damping regime also gradually decreased, but remained underdamped ca. $1850 \mathrm{CE}$. 

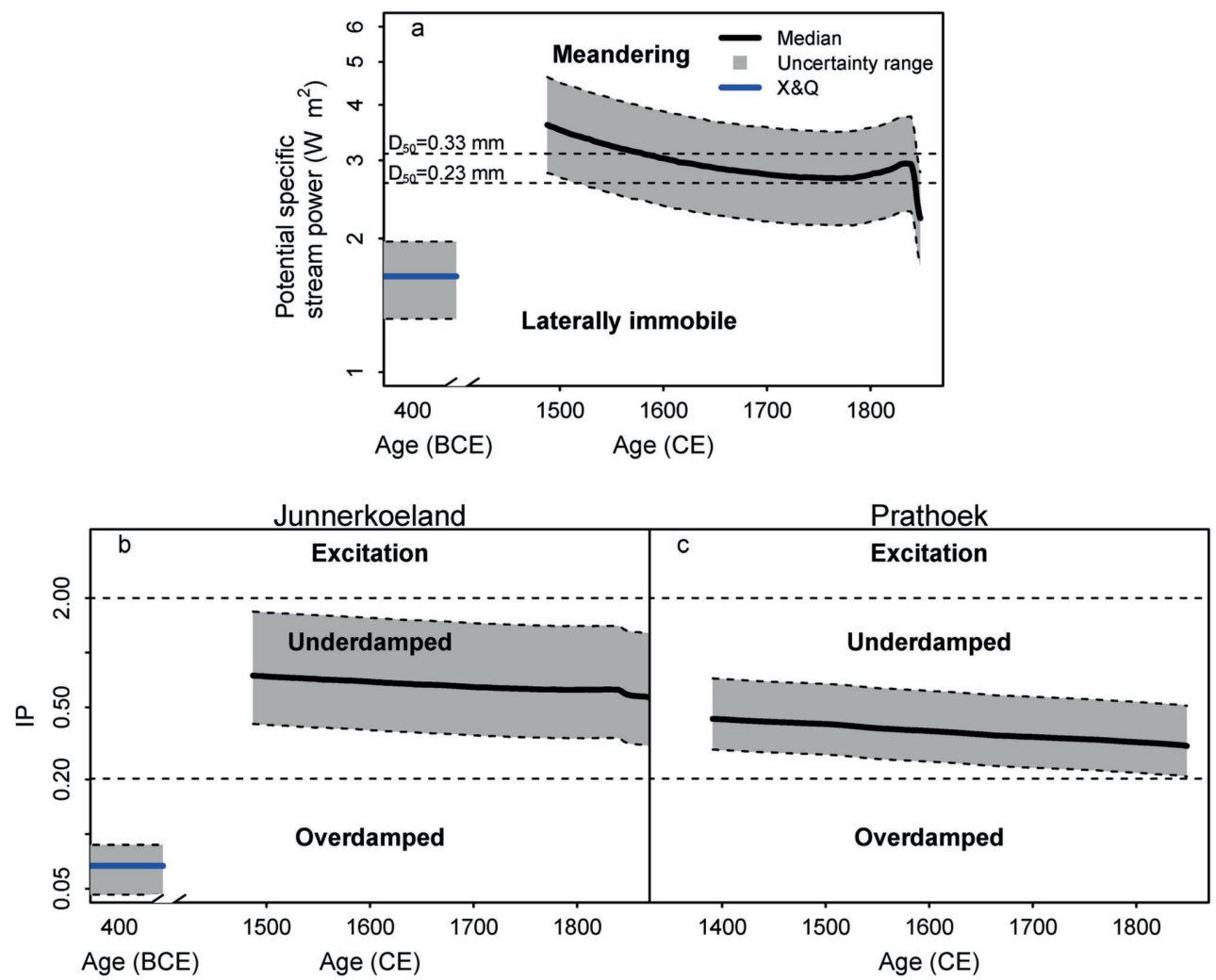

Figure 4.11 The potential for meandering with time. (a) The potential specific stream power in a stability diagram (Eq. 4.11). Several discriminators were plotted for a range of median particle sizes of the bed sediment, which is the range of particle sizes found in the scroll bars and Palaeochannel X\&Q (Figure 4.6). Panels (b) and (c) show the bar regime for both Junnerkoeland and Prathoek, determined with the interaction parameter (IP) (Eq. 4.18), and compared to the thresholds (Eqs. 4.19 and 4.20). Shading indicates the $16^{\text {th }}$ and $84^{\text {th }}$ quantile. X\&Q refers to palaeochannel X and Q. 


\subsection{Discussion}

\subsubsection{Laterally stable phase}

A relatively laterally stable phase existed prior to the meandering phase, which is corroborated by the geochronological and palaeohydrological reconstruction. Palaeochannel $\mathrm{X}$ formed by extremely slow channel displacement of ca. $6 \mathrm{~cm} \mathrm{yr}^{-1}$, assuming a constant channel displacement rate, shown by the OSL dates taken from the channel deposits on the inside of Palaeochannel X (Figures 4.1e and 4.4c, and Table 4.2). The lateral migration rate of the Junnerkoeland meander bend was ca. 40 times higher (Wolfert and Maas, 2007; Quik and Wallinga, 2018). The outer bank of Palaeochannel X consists of Weichselian and Early Holocene deposits. No Middle Holocene deposits were found in the corings (Figure 4.4c,d), reflecting the stable character of the Overijsselse Vecht during this period.

The preservation potential of deposits associated to the laterally stable phase is likely very small. Deposits and dimensions of active channel reaches are not preserved during the stable to meandering transition, because channel-belt dimensions increase. Hence, channel reaches are only preserved when they were cut off prior to the stablemeandering transition, e.g. due to local perturbations. A channel cut-off probably caused palaeochannels X and Q of the laterally stable phase to become disconnected from the main river before the meandering phase started. In this way these reaches escaped from later lateral erosion during the meandering phase. Consequently, the lateral stability of the river is not immediately evident from these preserved channel reaches, because the perturbations led to very slow channel displacement as was found for Palaeochannel X. However, scroll bar deposits did not form and lateral accretion surfaces were lacking (Figure 4.2, Figure 4.4e and Appendix 3), showing that the displacement was not related to meandering in which helicoidal flows cause bar formation and bank erosion at a significant rate and all along the channel (Seminara, 2006). The laterally stable phase lacked the potential to meander given its low position in Figure 4.11a, and is characterized by an overdamped regime (Figure 4.11b) and low sediment transport (Figure 4.10c). Consequently the formation of bars was suppressed, and the inner bank deposition was small (Figure 4.10c).

The bend curvature is also an indication for the channel stability. Palaeochannel X comprises of a very sharp bend $\left(\frac{R_{c u r v}}{W}=1.4 \pm 0.2\right)$ compared to the meandering phase $\left(\frac{R_{\text {curv }}}{W}=2.1 \pm 0.4\right)$, which is often found in low-energy rivers where lateral migration is limited (Hickin and Nanson, 1984; Candel et al., 2018a). Large similarities exist between the laterally stable phase reported here and the laterally stable channels in highly cohesive sediment on the intertidal mudflat, which are mostly laterally stable 
except from some sharp bends where bank failure and flow separation result in very limited and local channel migration (Kleinhans et al., 2009).

\subsubsection{Channel pattern change}

The Overijsselse Vecht River changed from a laterally stable into a meandering river. Differences in palaeohydrological conditions between both phases were large enough to distinguish, despite the large uncertainties in the palaeohydrological reconstruction. Bar regime changed from an overdamped regime into an underdamped regime (Figure $4.11 \mathrm{~b}-\mathrm{c}$ ), leading to overdeepening of the outer-bend pool and enhancement of the point bars in the innerbend (Struiksma et al., 1985; Crosato and Mosselman, 2009; Kleinhans and Van den Berg, 2011). The significantly higher bankfull discharge (factor three to nine, Figure 4.9) explains the potential to meander (Figure 4.11a), the high sediment transport, and the high scroll bar growth (Figure 4.10c) at the start of the meandering phase.

The exact moment of the channel pattern change is between the cut-off of Palaeochannel $\mathrm{X}(400 \pm 300 \mathrm{BCE})$ and the reconstructed initiation of scroll bar formation $(1504 \pm 52$ $\mathrm{CE}$ ). Most likely, the transition occurred shortly before the latter, because both pointbars had a relatively similar meander start age (Figures 4.2 and 4.4), the surrounding floodplain is formed by Late-Glacial or Early Holocene deposits (Figure 4.4), and there is no evidence of older scroll bar deposits in the vicinity of the studied meander bends. Mature meandering river systems would always leave traces of older scroll bar deposits, channel cut-offs or meander scars, because these are never completely being removed by the river (Toonen et al., 2012; Van de Lageweg et al., 2016).

The palaeohydrological reconstruction shows that the increasing bankfull discharge likely explains the channel pattern change. The increasing bankfull discharge may reflect an increase in annual discharge, but could also be related to a more irregular discharge regime, because the bankfull discharge largely represents the higher discharges in a river (Wolman and Miller, 1960; Dury, 1973). Consequently, the discharge may have been constant over a year with low peak discharges and a relatively high base flow during the laterally stable phase, changing into a more peaked discharge regime with a relatively low base flow at the start of the meandering phase.

A potential cause of the discharge regime and channel pattern change may be the climate change at the start of the Little Ice Age (14 ${ }^{\text {th }}$ to $19^{\text {th }}$ century) (Grove, 1988), given the overlap in time with the meandering phase (Figure 4.2c-d). Although geomorphological responses differ for each river during the Little Ice Age, enhanced lateral migration or incision was generally observed for most rivers in north-western Europe (Rumsby and Macklin, 1996). The increased bankfull discharge in the Overijsselse Vecht may have 
been caused by higher runoff relative to precipitation due to reduced evapotranspiration rates and frozen soils (Rumsby and Macklin, 1996; Van Engelen et al., 2001), and/or a higher snowfall/rainfall ratio due to lower winter temperatures in The Netherlands and Germany (Lenke, 1968; Behringer, 1999). Higher snowfall rates were also recorded for the United Kingdom (Manley, 1969), where it led to more flooding during the snowmelt period (Archer, 1992). Studies on historical observations of rivers nearby the Overijsselse Vecht (IJssel, Elbe, Lower Rhine and Meuse) suggested a significant higher flooding rate during the Little Ice Age compared to more recent flooding rates (Glaser and Stangl, 2003; Mudelsee et al., 2003, 2004; Glaser et al., 2010).

An additional cause for an increasing bankfull discharge may have been land use change in the catchment (Kondolf et al., 2002), which affects the discharge regime due to the direct relation with evapotranspiration (Fohrer et al., 2001). For the Overijsselse Vecht catchment, peat reclamation started in the $12^{\text {th }}$ and $13^{\text {th }}$ century (Gerding, 1995; Van Beek et al., 2015a), and intensified from the $14^{\text {th }}$ century onwards (Borger, 1992; Van Beek et al., 2015b). Reclamation of peatlands partly comprised digging of canals to drain the land, and although the reclamation was mainly limited to the margins of peatlands, the hydrological consequences were large. The margins are a natural seal of the peat bog, with a low hydraulic conductivity compared to the remainder of the bog, ensuring peat dome growth. Destruction of these margins will result in drainage of the entire peat bog (Van der Schaaf, 1999; Baird et al., 2008). After several centuries, focus shifted from peat reclamation to exploitation, excavating large peatland areas for fuel during the $17^{\text {th }}$ and $18^{\text {th }}$ century (Gerding, 1995). The largest part of the peat has currently disappeared. Yearly average discharges in peatlands can increase by $40 \%$ in the Dutch climatological setting, due to evapotranspiration differences for reclaimed peat areas compared to undisturbed peat areas (Baden and Eggelsmann, 1964; Uhden, 1967; Streefkerk and Casparie, 1987). This increase cannot fully explain the large increase of bankfull discharge in the Overijsselse Vecht (factor three to nine), because peat covered just ca. $27 \%$ of the Overijsselse Vecht catchment area during the $14^{\text {th }}$ century (Casparie and Streefkerk, 1992; Vos et al., 2011), hence the yearly average discharge of the catchment increased by ca. $11 \%$ due to evapotranspiration differences.

However, several studies have also shown that an increased drainage network in peatlands resulted in higher discharge peaks with a fast discharge response to precipitation (Conway and Millar, 1960; Streefkerk and Casparie, 1987; Holden et al., 2004; Holden et al., 2006). For example, the runoff/rainfall ratio was a factor three higher in a drained Irish peatland compared to an undrained Irish peatland (Burke, 1975), which is comparable to the observed bankfull discharge increase in the Overijsselse Vecht. Finally, canals were not only dug for peat reclamation, but also for shipping and effective generation 
of water power starting in the $11^{\text {th }}$ and $12^{\text {th }}$ century (Driessen et al., 2000), which may have promoted the higher peak flows even more. New canals resulted in a faster runoff, but also changed the watershed delineation (Driessen et al., 2000). We conclude that both climatic and land use changes were likely responsible for an increase in both total discharge and peak flows, resulting in the transition of a relatively stable river to a highly dynamic meandering system.

\subsubsection{Meandering phase}

Interestingly, the bankfull discharge declined during the meandering phase (Figure 4.9), leading to decreasing sediment transport relatively to the scroll bar growth (Figure 4.10c) and insufficient potential specific stream power for meandering after ca. $1850 \mathrm{CE}$ (Figure 4.11a). This decline was corroborated by observations of river width from previous studies, which can be compared to the reconstructed widths (Figure 4.8c-d). These observations included measurements from historical maps by Wolfert and Maas (2007) and measurements of the bankfull river width over a large river section in $1848 \mathrm{CE}$ by Staring and Stieltjes (1848). The river width data from Wolfert and Maas (2007) largely fall in the range of reconstructed bankfull widths at Junnerkoeland, and show a similar decreasing trend (Figure 4.8c). However, the historical maps used by them may result in large uncertainties, because the water stage that these maps represent is unknown (Quik and Wallinga, 2018). The measured widths by Staring and Stieltjes (1848) are in line with the predicted width at Junnerkoeland, falling within the uncertainty range. The predicted width at Prathoek is underestimated compared to the measured widths by Wolfert and Maas (2007) and Staring and Stieltjes (1848). This underestimation may explain the lower cross-sectional area compared to Junnerkoeland (Figure 4.8f), and hence an underestimated bankfull discharge (Figure 4.9) and potential specific stream power (Figure 4.10).

The observed decline of bankfull discharge would suggest that the hydrological forcing disappeared or diminished, and had a temporary character, which would fit the Little Ice Age that ended in the $19^{\text {th }}$ century as potential cause. Consequently, it would be expected that the channel pattern reorganized and became laterally stable again. However, the river was still laterally migrating until channelization between 1896 and 1914 CE (Wolfert and Maas, 2007), which may be related to the presence of an underdamped regime enhancing point bar formation in the inner bend (Figure 4.11b-c). Additionally, historical bank stability changes may have promoted the river meandering during this period. For example, floodplains were intensively used for cattle grazing, which may have weakened the banks, enhancing meandering after 1850 CE (Trimble and Mendel, 1995; Wolfert et al., 1996; Beschta and Ripple, 2012). Also drift-sand activity was initiated by intensive land use since the Late Middle Ages (Figure 4.1c-d) (Koster et al., 1993), which may have affected the bank stability. 


\subsection{Conclusions}

We show that bankfull discharge and associated river parameters can be reconstructed by following a stochastic approach, and through detailed geochronological and lithological analysis of scroll bar deposits and palaeochannels. For the Overijsselse Vecht River we demonstrate that an increase in bankfull discharge ca. 1400 to $1500 \mathrm{CE}$ resulted in a river channel pattern change from laterally stable to meandering. Geochronological data confirmed our hypothesis on the lateral stability of the river prior to the meandering phase, in contrast to previous assumptions that were made of continuous meandering during the Holocene. We show that the reconstructed river parameters are consistent with both the laterally stable and meandering channel pattern by applying empirical channel and bar pattern models. Potential causes for the discharge regime changes include climate change (Little Ice Age) and land use changes (peat reclamation, peat exploitation, digging of canals). We conjecture that the change from laterally stable to meandering has occurred in other rivers for which increased Holocene fluvial activity was reported.

\section{Acknowledgments}

This chapter has benefited greatly from reviews by Peter Houben and two anonymous reviewers. The authors would like to thank the following persons for their help with the different methods used in this research: Joep Storms, Gerard Heuvelink, Marijn van der Meij, Wobbe Schuurmans, Alice Versendaal, Erna Voskuilen, Aldo Bergsma, Marjolein Gouw-Bouman, and UU students Karianne van der Werf, Sjoukje de Lange, Jip Zinsmeister, and Pascal Born. We would also like to thank the De Roos family, Staatsbosbeheer, and Waterschap Vechtstromen for access to and inside knowledge of the field sites. 



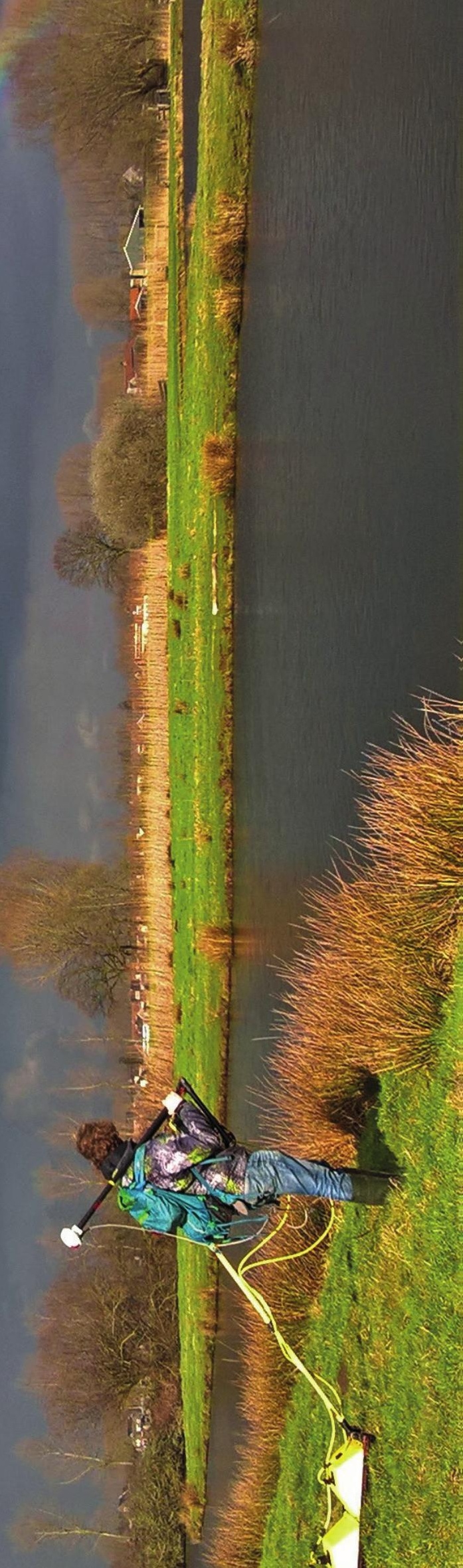




\section{Chapter 5}

\section{Predicting river channel pattern based on stream power, bed material and bank strength}




\title{
Chapter 5
}

\begin{abstract}
Rivers exhibit a wide variety of channel patterns. Many discriminators have been developed to define approximate boundary conditions for different channel patterns. Usually, discriminators are functions describing a line in a diagram in which the observed channel pattern of river reaches is plotted based on channel-pattern-controlling parameters. The present discriminators have two main shortcomings. Firstly, these discriminators seem to perform relatively poorly for rivers with cohesive, relatively erosion-resistant banks. For this subset, discriminators tend to indicate an actively meandering channel pattern, whereas the river morphology and dynamics show that many of these rivers should be classified as a laterally stable channel pattern. Secondly, channel pattern discriminators are often used to predict channel patterns, however, they use parameters that are dependent on actual channel pattern, which invalidates prediction. Channel pattern prediction is only valid when parameters are used independent of actual channel pattern. To resolve both shortcomings, we first propose an additional class of rivers with scroll bars and tortuous channel patterns to the channel pattern classification, which have an inhibited mobility due to their self-formed cohesive deposits. Secondly, we compare frequently-used empirical and physics-based channel pattern discriminators and test which of these is the most successful in terms of prediction and discuss the independence of causal factors used. Thirdly, we present a novel channel pattern discriminator and predictor that takes the effect of a cohesive floodplain into consideration by including the average silt-plus-clay fraction of the river banks.
\end{abstract}

Submitted manuscript: Candel, J. H. J., M. G. Kleinhans, B. Makaske, and J. Wallinga, in review. Predicting river channel pattern based on stream power, bed material and bank strength: Progress in Physical Geography. 
Predicting river channel pattern based on stream power, bed material and bank strength

\subsection{1 ntroduction}

\subsubsection{River channel patterns}

Rivers are principle geomorphic agents shaping the Earth's surface (Petts and Foster, 1985; Osborn and du Toit, 1991; Black et al., 2017), and worldwide exhibit a wide range of channel patterns, such as braided and meandering (Leopold and Wolman, 1957; Church, 2002) (Figure 5.1). Channel patterns are defined and classified by their morphometric characteristics, such as the spatial arrangement of channels, bars and the floodplain within the landscape (Nanson and Croke, 1992; Makaske, 2001; Twidale, 2004; Kleinhans, 2010).

An improved understanding of channel patterns is vital for river restoration projects, in which rivers are being restored to their natural state with freely-eroding banks (Wohl et al., 2015). Often, rivers are restored into meandering rivers, even when the geomorphic conditions do not support this channel pattern (Kondolf, 2006). A better prediction of channel pattern is needed to align the river channel pattern with the geomorphic conditions, to enhance the sustainable management of rivers and predict river response to allogenic forcing (Brierley and Fryirs, 2009). River channel patterns may change due changes of land use (e.g. urbanization or deforestation) and climate, and associated changes of river mobility may have large consequences to surrounding habitation and infrastructure (Kondolf et al., 2002; Lewin and Macklin, 2010; Candel et al., 2018b). Interpretation of the palaeoenvironment from fluvial sedimentary archives also requires a thorough understanding of how channel patterns form (Vandenberghe, 2002; Lewin et al., 2005; Miall, 2014).

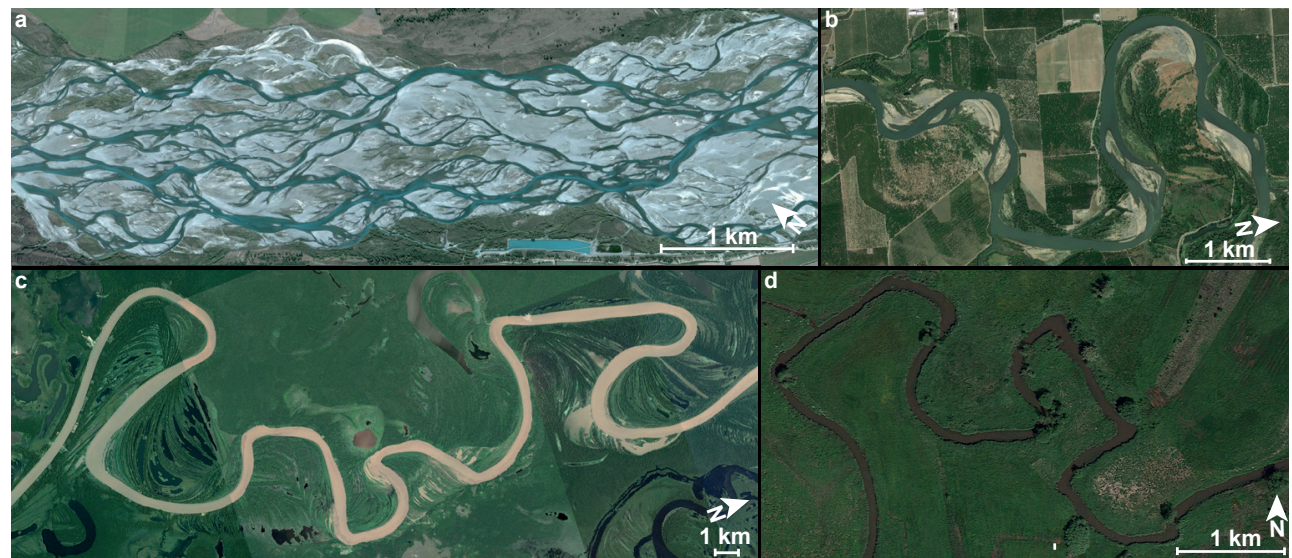

Figure 5.1 Different river channel patterns. a) A braided river pattern of the Rakaia River in New-Zealand (4339'13.73"S $\left.\left.171^{\circ} 51^{\prime} 29.32^{\prime \prime} \mathrm{E}\right), \mathrm{b}\right)$ a meandering river pattern with chute bars of the Sacramento River in the USA (39 $\left.39^{\prime} 14.21^{\prime \prime} \mathrm{N} 121^{\circ} 58^{\prime} 56.00^{\prime \prime} \mathrm{W}\right)$, c) a meandering river pattern with scroll bars of the Mamore River in Bolivia (1 $\left.1^{\circ} 59^{\prime} 24.63^{\prime \prime} S 65^{\circ} 623.48^{\prime \prime W}\right)$, d) a laterally stable river pattern of the Barwon River in Australia ( $\left.30^{\circ} 00^{\prime} 00.0^{\prime \prime} \mathrm{S} 147^{\circ} 58^{\prime} 00.0^{\prime \prime} \mathrm{E}\right)$. 


\subsubsection{Channel pattern discriminators}

Channel pattern discriminators discriminate channel patterns based on a variety of parameters (e.g. Lane, 1957; Leopold and Wolman, 1957; Parker, 1976; Fredsøe, 1978; Chang, 1985; Ferguson, 1987; Van den Berg, 1995; Eaton et al., 2010; Kleinhans and Van den Berg, 2011). Figure 2 shows an example of these discriminators. Here we define discriminators as quantitative separators of zones in a diagram that represent the highest probability of existence of channel patterns, and these separators are based on one or more parameters. Discriminators may have a transitional character and do not form physical thresholds, meaning that channel patterns moving closer to the discriminator in the diagram (e.g. Figure 5.2) gradually change into the new channel pattern (Ferguson, 1987; Van den Berg, 1995; Bledsoe and Watson, 2001; Kleinhans and Van den Berg, 2011). Most channel pattern discriminators are empirical based, but some physics-based discriminators were developed (e.g. Parker, 1976; Seminara and Tubino, 1989; Crosato and Mosselman, 2009; Kleinhans and Van den Berg, 2011). The advantage of such physics-based discriminators is that they can give insight into the physical processes that determine river channel pattern, while empirical discriminators are more like a black box (Kleinhans, 2010). However, the application of physics-based discriminators commonly requires more parameters to be known than the application of empirical discriminators.

Although originally solely developed to better understand at which conditions different channel patterns occur (Leopold and Wolman, 1957), discriminators using channeldependent and morphometric parameters are still being developed and used to predict river channel pattern (e.g. Beechie et al., 2006; Crosato and Mosselman, 2009; Eaton et al., 2010; Akhtar et al., 2011; Beechie and Imaki, 2014; Dey, 2014; Ganti et al., 2019). Here we define a channel pattern predictor as a quantitative separator or set of separators of zones in a diagram that represent the highest probability of existence of channel patterns, whereas this separator or these separators are based on one or more process-based parameters that are independent of channel pattern and provide the initial conditions for the channel pattern to develop. With time, realization has grown that discriminators have no predictive value when channel-dependent and morphometric parameters are used for the discrimination of channel pattern (Carson, 1984; Knighton, 1984), such as the parameters bankfull width, channel slope, width-depth ratio or sinuosity. Hence, channel-independent, process-based parameters were proposed and applied to discriminate the initial conditions that result in meandering and braided rivers (Carson, 1984; Ferguson, 1987; Van den Berg, 1995), meaning all parameters that could be measured when there would be no river channel present yet within the valley. However, limited effort is undertaken to develop these channel pattern predictors. 
Predicting river channel pattern based on stream power, bed material and bank strength

\subsubsection{Controlling parameters of channel pattern}

The type of channel pattern results from the balance of floodplain erosion and floodplain formation (Kleinhans, 2010), which is determined by the shear stress (i.e. stream power), calibre and quantity of sediment load, and bank strength (Nanson and Croke, 1992; Kleinhans, 2010). Initially, Leopold and Wolman (1957) and Lane (1957) suggested to empirically discriminate meandering and braided rivers with just two controlling parameters, bankfull discharge $\left(\mathrm{Q}_{\mathrm{bf},} \mathrm{m}^{3} \mathrm{~s}^{-1}\right)$ and channel slope $\left(\mathrm{S}_{\mathrm{c}},-\right)$ :

$$
S_{c}=0.013 Q_{b f}^{-0.44}
$$

Later it was shown that the median bed grain size is an important discrimination parameter, because it determines what shear stress is needed for transporting bed material (Carson, 1984; Ferguson, 1987), which was applied in an empirical channel pattern discriminator by Van den Berg (1995) and Eaton et al. (2010). Studies using both physics-based and empirical channel pattern discriminators also showed that the width-depth ratio of the river channel is an important discriminating factor (e.g. Fujita, 1989; Bridge, 1993; Eaton and Millar, 2004; Crosato and Mosselman, 2009), which strongly depends on bank strength (Schumm, 1960; Ferguson, 1987). Fredsøe (1978) showed that the meanderingbraided transition occurs approximately at a width-depth ratio of 50 .

The floodplain properties strongly control the bed material grain size and bank strength, and are thus important for the discrimination of channel patterns (Carson, 1984; Ferguson, 1987; Nanson and Croke, 1992; Eaton and Giles, 2009; Kleinhans, 2010), but have hardly been included in discriminators. Eaton et al. (2010) described a conceptual channel pattern discriminator including the bank strength, but quantification based on data was beyond the scope of their research. Bank strength is a function of sediment cohesiveness (Julian and Torres, 2006), but also depends on vegetation (Millar, 2000; Gurnell, 2014), and factors such as groundwater seepage (Van Balen et al., 2008; Eekhout et al., 2013), grazing animals (Trimble and Mendel, 1995; Beschta and Ripple, 2012) and human activities (Kondolf et al., 2002; Gibling, 2018). This complexity hampers quantification of bank strength (Hickin and Nanson, 1984). Nevertheless, Nanson and Hickin (1986) showed that the grain size of the river banks was the most important factor explaining bank erosion rates, while other factors had limited effect.

The influence of bank cohesiveness was nicely illustrated by Simpson and Smith (2001), who showed that the Leopold and Wolman (1957) discriminator failed to discriminate the channel pattern difference between a meandering reach and braided reach of the sandbed Milk River. They found that the silt-plus-clay fraction of the channel banks dropped strongly from $65 \%$ in the meandering reach to $18 \%$ in the moderately braided reach 


\section{Chapter 5}

and increased again to $85 \%$ in the laterally stable reach. They stressed the importance of including the silt-plus-clay fraction in the channel pattern discriminator, especially for sand-bed rivers. Similarly, Labbe et al. (2011) showed that the channel form changed primarily due to a change in bank material along the Upper Tualatin River, USA. Finally, Candel et al. (in review) showed that the average silt-plus-clay fraction of river banks could be used to discriminate self-constrained rivers with complex channel patterns from meandering rivers with classical sinuous channel patterns.
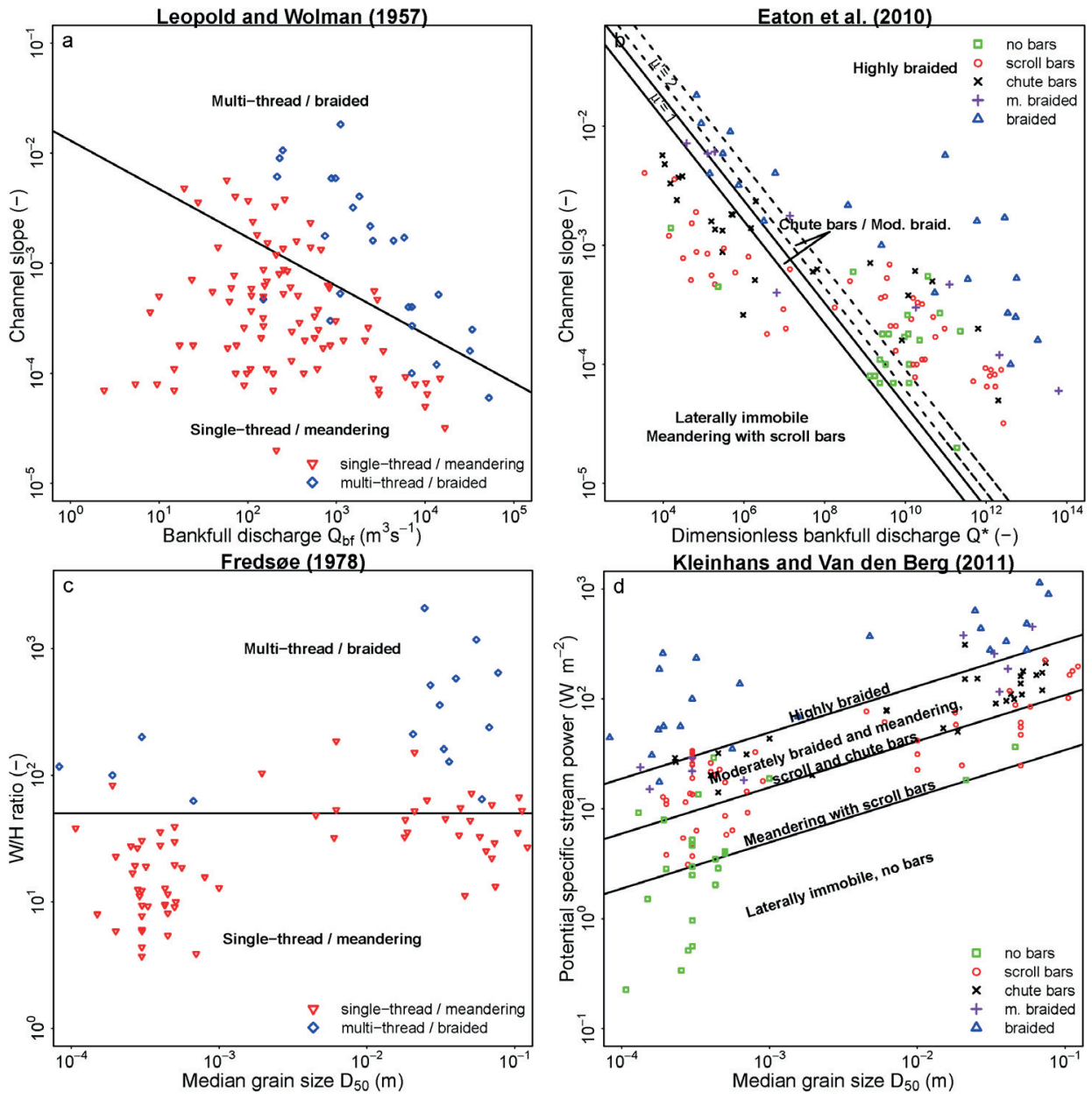

Figure 5.2 Empirical channel pattern discriminators (black lines) compared with the data of Kleinhans and Van den Berg (2011). a) Channel pattern prediction by Leopold and Wolman (1957) (Eq. 5.1), b) Eaton et al. (2010), the dashed lines indicate an example for when $\mu^{\prime}=2$, but we used $\mu^{\prime}=1$ in relation to the data in Table 5.1 (Eq. 5.2), c) Fredsøe (1978), d) Kleinhans and Van den Berg (2011) (Eqs. 5.6 to 5.8). Table 5.1 indicates the fraction of correctly classified rivers. 
Predicting river channel pattern based on stream power, bed material and bank strength

\subsubsection{Research aim}

Empirical and physics-based channel pattern discriminators are often used as predictors of channel pattern, while they commonly use channel-dependent and morphometric parameters, and tend to ignore the floodplain properties despite their large effect on channel pattern. In this research we aim to identify which existing channel pattern discriminator is most suitable for predicting channel pattern (Sect. 5.2), and to develop a new channel pattern predictor that takes bank strength into account (Sect. 5.3).

\subsection{Comparison of channel pattern discriminators and their discriminative power}

\subsubsection{River dataset and channel pattern characterization}

First, we will describe the river dataset and the method of channel pattern characterization (this section), after which we will test and compare six channel pattern discriminators (Sect. 5.2.2 to 5.2.4). To compare the different channel pattern discriminators we will use the dataset compiled by Kleinhans and Van den Berg (2011). The dataset, extended by Candel et al. (in review), now consists of 135 natural rivers in alluvium that are in a dynamic equilibrium condition over a length scale of a few tens of meander lengths, all checked for channel pattern by using satellite and aerial imagery (Google Earth) by Kleinhans and Van den Berg (2011) and (Candel et al., in review). Rivers were subdivided into single-thread and multi-thread rivers. Single-thread rivers were further subdivided into immobile rivers when bars were absent, meandering rivers with scroll bars, and meandering rivers with chute bars (see Figure 5.1). Multi-thread rivers were subdivided based on their braiding index $\left(\mathrm{B}_{\mathrm{i}}\right)$ into moderately braided $\left(\mathrm{B}_{\mathrm{i}}=1.2-3\right)$ and highly braided $\left(\mathrm{B}_{\mathrm{i}}>3\right)$ (Kleinhans and Van den Berg, 2011). The braiding index is defined as the average cross-sectional number of active braids; it was derived by visually counting the active braids following Egozi and Ashmore (2008). Furthermore, the dataset contains information on valley slope $\left(S_{v},-\right)$, channel slope $\left(S_{c},-\right)$, sinuosity, mean annual flood discharge $\left(\mathrm{Q}_{\mathrm{ma}}, \mathrm{m}^{3} \mathrm{~s}^{-1}\right)$, bankfull discharge $\left(\mathrm{Q}_{\mathrm{bP}} \mathrm{m}^{3} \mathrm{~s}^{-1}\right)$, and median bed grain size $\left(\mathrm{D}_{50}, \mathrm{~m}\right)$. The mean annual flood discharge represents the effective channelforming discharge $\left(\mathrm{Q}_{\mathrm{ep}} \mathrm{m}^{3} \mathrm{~s}^{-1}\right)$, and when not available the bankfull discharge was taken (see foundations of choice given by Kleinhans and Van den Berg (2011)). For 81 rivers additional information was available on the hydraulic geometry of the channel (bankfull width $\left(\mathrm{W}_{\mathrm{bP}} \mathrm{m}\right)$ and depth $(\mathrm{H}, \mathrm{m})$ ). All rivers in the dataset have a perennial flow regime, no engineering works along the river, and no signs of strong modification of the hydrological regime (e.g. no underfit river patterns). 
Quantitative data on average silt-plus-clay fractions of the river banks in the reaches of interest are available in the literature for about half of the rivers of the dataset (70 out of 135). Candel et al. (in review) provided a part of this dataset for the single-thread rivers, and here we further extend this dataset by adding silt-plus-clay fractions for the braided rivers in the dataset, if available in literature. Where ranges of silt-plus-clay fractions were reported, we used the middle of the range. In general, samples were taken from the exposed river banks at several depths, after which they were sieved in the laboratory. Sampling methods and texture analysis slightly varied between studies that reported silt-plus-clay fractions. More details on methods used is provided in the cited sources in Appendix 4.

A critical review indicated that not all alluvial rivers with scroll bars are laterally active. Candel et al. (in review) showed that many low-energy alluvial rivers with scroll bars are in fact more or less laterally stable, because they have constrained their channel pattern within their self-formed cohesive deposits. The proportion of these cohesive deposits increases with time, because low-energy rivers predominantly erode the easily erodible, non-cohesive deposits, while they continuously form both easily erodible and relatively erosion-resistant deposits. Consequently, the lateral migration of the river decreases with time. Scroll bars in these rivers may be inherited from past meandering activity or may result from local lateral migration where the river is able to erode a non-cohesive bank. This self-constraining of meandering rivers results in a tortuous, complex channel pattern, i.e. channel patterns with unusually sharp bends with variable size and abrupt, irregular changes in channel direction, lacking the typical smoothness and regularity of conventional meander curves (Schumm, 1963; Candel et al., in review). Candel et al. (in review) developed a metric to quantify the tortuosity of river channel pattern, by taking the fraction of sharp bends with a $\frac{\mathrm{R}_{\text {curv }}}{\mathrm{w}}<2.0\left(R_{\text {curv }}=\right.$ bend curvature, $w=$ channel width) of 20 consecutive meander bends, using satellite imagery from Google Earth. They showed that rivers with a tortuosity larger than 0.35 are more or less laterally stable rivers that have likely been subjected to self-constraining. Therefore, we take rivers that have both scroll bars and a tortuous channel pattern as a separate channel pattern group in the channel pattern prediction that will be developed here. 
Predicting river channel pattern based on stream power, bed material and bank strength

\subsubsection{Empirical channel pattern discriminators}

The channel pattern discriminator of Leopold and Wolman (1957) (Figure 5.2a) discriminates only between meandering and braided rivers (Eq. 5.1). Eaton et al. (2010) proposed to combine the channel slope discriminator with the bankfull discharge, median bed grain size, and add bank strength ( $\left.\mu^{\prime},-\right)$ to the empirical equation (Figure 5.2b). They defined $\mu$ ' as the relative bank strength given by the ratio of the critical shear stress for entrainment of the channel banks to the critical shear stress for the channel bed. When bed and banks consist of the same material, $\mu^{\prime}=1$. Hence, the discriminator do not have fixed positions and shift for each river reach depending on $\mu^{\prime}$. Unfortunately, data is not available to derive $\mu$ '. Their discriminator is defined by:

$$
S_{c}=0.56 B_{i}^{0.43} \mu^{\prime} Q^{*-0.43}
$$

where $\mathrm{Q}^{*}$ is the dimensionless bankfull discharge given by:

$$
Q^{*}=\frac{Q_{b f}}{D_{50}^{2} \sqrt{\left(\frac{\rho_{s}}{\rho}-1\right) g D_{50}}}
$$

where $\rho$ is the water density $\left(\mathrm{kg} \mathrm{m}^{-3}\right), \rho_{s}$ is the sediment density $\left(\mathrm{kg} \mathrm{m}^{-3}\right)$, and $g$ is the gravitational acceleration $\left(\mathrm{m} \mathrm{s}^{-2}\right)$.

Van den Berg (1995) proposed the potential specific stream power as an independent measure of river energy needed to move sediment, which is defined by:

$$
\omega_{p o t}=\frac{\rho g Q_{e f} S_{v}}{W_{r}}
$$

where $\omega_{\text {pot }}$ is the potential specific stream power $\left(\mathrm{W} \mathrm{m}^{-2}\right)$, and $\mathrm{W}_{\mathrm{r}}$ is the reference channel width $(\mathrm{m})$ :

$$
\mathrm{W}_{\mathrm{r}}=\propto \sqrt{Q_{e f}}
$$

where $\propto=4.7 \sqrt{s m^{-1}}$ for sand-bed rivers and $\propto=3.0 \sqrt{s m^{-1}}$ for gravel-bed rivers (Van den Berg, 1995). The valley slope is independent of channel sinuosity in contrast to the channel slope; the mean annual flood is a frequency-based hydrological parrameter and hence less dependent on channel geometry than the bankfull discharge; the reference width follows from a hydraulic geometry relation applied irrespective of channel pattern (Van den Berg, 1995). 


\section{Chapter 5}

Van den Berg (1995) defined the discriminator between a braided and meandering pattern (Figure 5.2d):

$$
\omega_{b m}=900 D_{50}^{0.42}
$$

where subscript $\mathrm{bm}$ refers to the braided-meandering pattern transition. Makaske et al. (2009) added an extra discriminator, discriminating laterally stable from meandering rivers, primarily based on the laterally stable branches of the anastomosing upper Columbia River:

$\omega_{i a}=90 D_{50}^{0.42}$

where subscript $i a$ refers to the inactive-active pattern transition. The $\omega_{i a}$ - discriminator is defined at a tenfold lower stream power than the $\omega_{\mathrm{bm}}$ - discriminator. Kleinhans and Van den Berg (2011) further developed the approach by Van den Berg (1995) and Makaske et al. (2009), by discriminating between different styles of meandering and braided; i.e. meandering rivers with scroll bars can occur in a lower energetic regime than chute-dominated meandering rivers and moderately braided rivers. Their discriminator between the two styles of meandering is defined by (Figure $5.4 \mathrm{~d}$ ):

$\omega_{s c}=\frac{900}{\sqrt{10}} D_{50}^{0.42}$

where subscript $s c$ refers to the scroll-dominated and chute-dominated pattern transition.

This discriminator is defined halfway between the $\omega_{i a}$ and $\omega_{\mathrm{bm}}$ discriminators on a logscale (Figure 5.2d).

Makaske et al. (2009) and Kleinhans and Van den Berg (2011) have defined the slopes of the new $\omega_{i a}$ - and $\omega_{s c}$-discriminators parallel to the already existing $\omega_{\mathrm{bm}}$-discriminator that was determined by discriminant analysis by Van den Berg (1995), and confirmed by logistic regression analysis by Bledsoe and Watson (2001). To confirm the slope of the discriminators as shown in Figure 5.2d, we derived an independent relation between $\omega_{b f}$ and $\mathrm{D}_{50}$ for a large river dataset that combines the river data by Kleinhans and Van den Berg (2011) and Li et al. (2015). This analysis can be found in Appendix 5, and confirmed the slope of the discriminators as defined by Kleinhans and Van den Berg (2011) in Eqs. 5.6 to 5.8 . 


\subsubsection{Physics-based channel pattern discriminators}

Parker (1976) showed that river patterns are determined by the occurrence of instability of the flow and the bed. He developed the first theoretical stability criterion $(\varepsilon)$ to discriminate meandering from braided rivers, which represents the ratio of sediment transport to water transport (Figure 5.3):

$$
\epsilon=S_{c} \frac{\sqrt{g H W_{b f}^{4}}}{Q_{b f}}
$$

The river channel pattern is meandering when $\varepsilon<1$, and braided when $\varepsilon \geq 1$.

The physics-based bar theory by Struiksma et al. (1985) shows that the width-depth ratio determines bar formation and braided index, which relates to the differences in the direction of sediment transport compared to depth-averaged flow as a result of gravitational effects on transverse and longitudinal slopes. On the basis of this theory, Crosato and Mosselman (2009) developed the most recent physics-based channel pattern discriminator to discriminate meandering and braided rivers, building further on earlier efforts (Struiksma et al., 1985; Seminara and Tubino, 1989; Tubino and Seminara, 1990). Kleinhans and Van den Berg (2011) showed that these relations can also be applied to discriminate immobile rivers without bars from meandering rivers. However, Crosato and Mosselman (2009) only developed discriminators for either sand-bed or gravel-bed rivers, not discriminating further based on median bed grain size.

In the Appendix 5 we elaborate upon the underlying formulas of the physics-based discriminator by Crosato and Mosselman (2009). We derived two new equations to discriminate channel pattern based on width-depth ratio as a function of median bed grain size.

$$
\left(\frac{W_{b f}}{H}\right)_{i a}=\sqrt{\left(\frac{C^{2} \pi^{2}}{g \mathrm{f}(\theta)\left(1+\frac{0.0171 D_{50}^{-0.72}}{0.0057 D_{50}^{-0.72}-\theta_{c}}+2 \sqrt{\left(\frac{0.0342 D_{50}^{-0.72}}{0.0057 D_{50}^{-0.72}-\theta_{c}}-2\right)}\right)}\right)}
$$




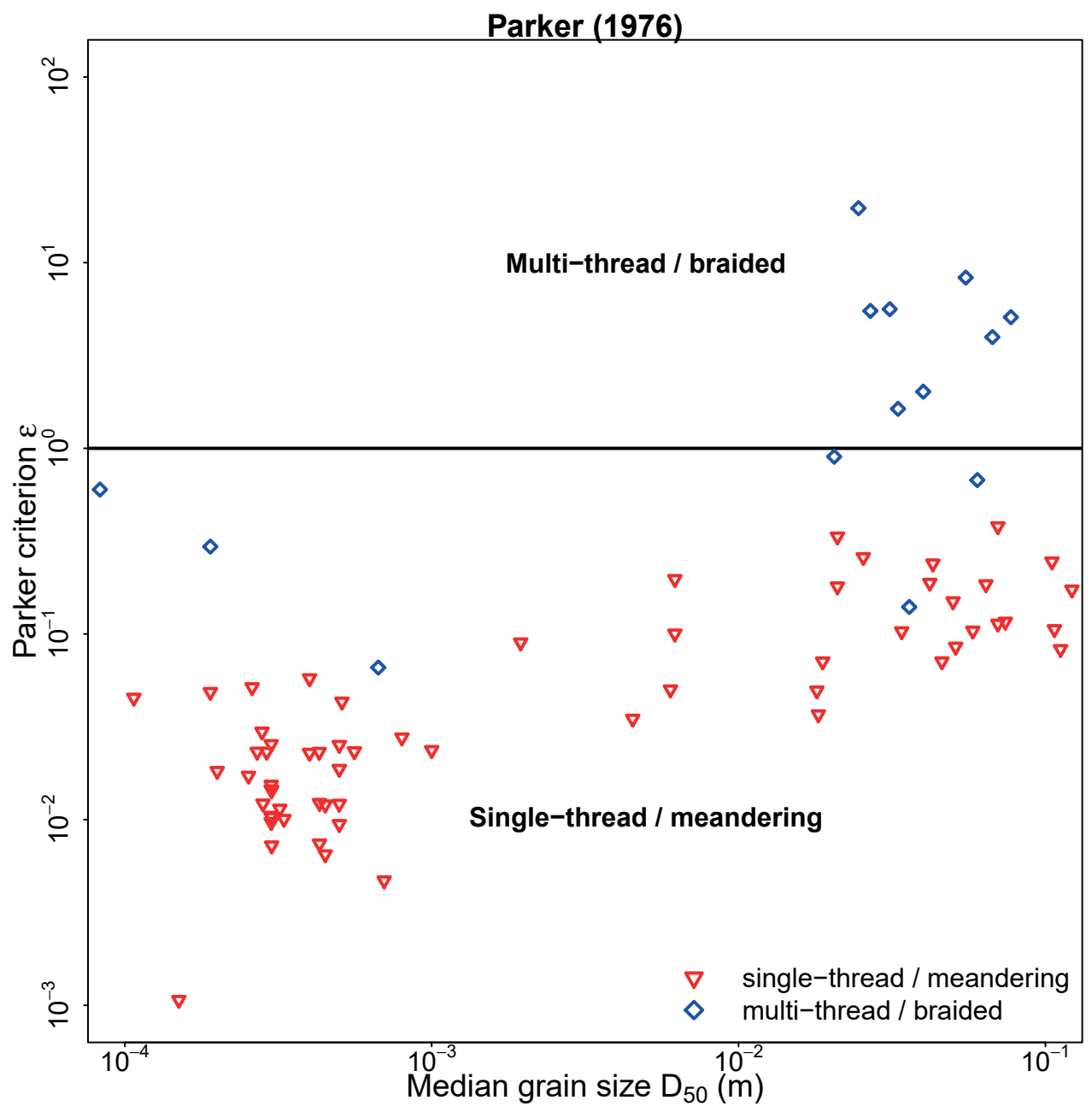

Figure 5.3 Physical channel pattern discriminator (black line) by Parker (1976), compared with the data of Kleinhans and Van den Berg (2011) (Eq. 5.9). Table 5.1 indicates the fraction of correctly classified rivers. 


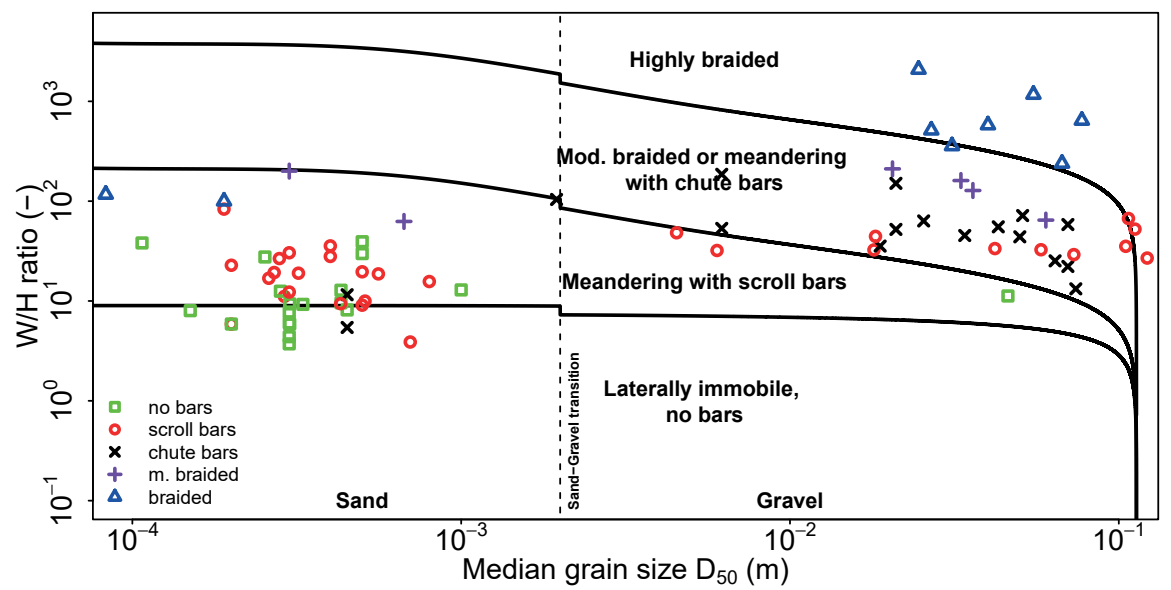

Figure 5.4 Discriminators of channel pattern derived from the physical laws of Struiksma et al. (1985), combined with data of rivers from the dataset of Kleinhans and Van den Berg (2011). The separators are given by the width-depth ratio $(\mathrm{W} / \mathrm{H})$ as a function of $\mathrm{D} 50$, calculated by Eqs. 5.10 and 5.11 , further explained in Appendix 5. The step at the gravel-sand transition is due to the different magnitude of the transverse slope effects assumed in Baar et al. (2018). The asymptote at the largest particle size is due to the threshold for motion. See for more details Suppl. Information.

$\left(\frac{W_{b f}}{H}\right)_{s c \& b m}=m \sqrt{\left(\frac{C^{2} \pi^{2}}{g \mathrm{f}(\theta)\left(\frac{0.0171 D_{50}^{-0.72}}{0.0057 D_{50}^{-0.72}-\theta_{c}}-3\right)}\right)}$

where $C$ is the Chézy coefficient $\left(\mathrm{m}^{0.5} \mathrm{~s}^{-1}\right), \mathrm{m}$ is the bar mode, $\mathrm{f}(\theta)$ is the magnitude of the transverse slope effect $(-)$ and $\theta_{c}$ is the critical Shields stress (-). These discriminators should be interpreted as semi-physical, because we use an empirical relation to derive these equations. The three discriminators (Figure 5.4) are derived by Eqs. 5.10 and 5.11, with the upper discriminator $(b m) \mathrm{m}=5\left(\mathrm{~B}_{\mathrm{i}}=3\right)$, and middle discriminator $(s c) \mathrm{m}=1.4$ $\left(B_{i}=1.2\right)$. See Appendix 5 for the explanation of the parameters.

From Figure 5.4 it can be derived that the number of bars is higher in rivers with a high width-depth ratio $(\mathrm{W} / \mathrm{H})$ than in rivers with a low width-depth ratio, and braided river channel patterns or rivers with chute bars are more numerous in gravel-bed rivers compared to sand-bed rivers, because bars form much easier with increasing widthdepth ratio in gravel-bed rivers than in sand-bed rivers (Kleinhans and Van den Berg, 2011). Meandering rivers with scroll bars (i.e. rivers with an underdamped regime, see explanation in Appendix 5) are less likely to exist with increasing median grain size, because the lower discriminators converge (Figure 5.4). 


\subsubsection{Evaluation and comparison of discriminators as predictors}

The percentage of correctly classified channel patterns by using the different discriminatory criteria (Table 5.1). Additionally, we used the kappa statistic ( $\kappa$ ) to test interrater reliability, with $\kappa<0$ indicating no agreement, $0-0.2$ slight, $0.21-0.40$ fair, $0.41-0.60$ moderate, $0.61-0.80$ substantial, and $0.81-1$ almost perfect agreement (see calculation of kappa in Landis and Koch, 1977). The $\kappa$ statistic accounts for the number of channel patterns categorised, and thus allows comparison between the different discriminators.

The physics-based discriminator by Parker (1976) works well for meandering rivers ( $100 \%$ correct), but performs less for braided rivers ( $57 \%$ correct). Overall, it shows substantial agreement $(\kappa=0.69)$ between the observation and discrimination of channel patterns. The advantage of the physics-based discriminators that we developed (Eqs. 5.10 and 5.11, based on Crosato and Mosselman (2009)) is that they can be used to discriminate more types of channel patterns than many other channel pattern discriminators (Table 5.1). However, this method has the disadvantage that it uses morphometric parameters that are channel pattern dependent, such as width-depth ratio, like the physics-based discriminator by Parker (1976) and the empirical channel pattern discriminators by Leopold and Wolman (1957), Eaton et al. (2010) and Fredsøe (1978). The data do not fully support the physical model of bar theory by Crosato and Mosselman (2009), because only 63\% of all channel patterns was discriminated correctly, which is a moderate agreement between the observed and discriminated channel patterns (Figure 5.4, Table 5.1, $\kappa=0.48$ ). Within the group of sand-bed rivers on the left side of the graph (Figure 5.4), the high-energy river patterns (i.e. braided and chute bars) are relatively poorly discriminated, and rivers with scroll bars cannot be discriminated from laterally stable rivers. Within the group of gravel-bed rivers on the right side of the graph, the physics-based discriminators perform better, especially for the high-energy river patterns. Here the critical motion of bed sediments forms the limit of the channel pattern discrimination, explaining the asymptote at the largest particle size (Figure 5.4). The difference in discrimination success between sand-bed and gravelbed rivers is likely explained by the effect of bank strength, because rivers with cohesive banks are not able to form wide channels (Schumm, 1960; Millar, 2000; Soar and Thorne, 2001). Eaton and Giles (2009) and Candel et al. (in review) showed that bank strength has its strongest effect on inhibiting bank erosion in sand-bed rivers, because gravel-bed rivers require sufficiently high energy for the critical motion of their coarse bed sediment and are thus always able to erode cohesive banks. 
Predicting river channel pattern based on stream power, bed material and bank strength

Table 5.1 Percentages of correctly plotted channel patterns and $\kappa$ coefficient by using different discriminatory criteria as shown in Figures 5.3 and 5.4 using the dataset of Kleinhans and Van den Berg (2011). Discriminators are from Parker (1976) (Figure 5.3), Crosato and Mosselman (2009) (our own derivation in Figure 5.4), Fredsøe (1978) (Figure 5.2c), Leopold and Wolman (1957) (Figure 5.2a), Eaton et al. (2010) (Figure 5.2b), and Kleinhans and Van den Berg (2011) (Figure 5.2d).

\begin{tabular}{|c|c|c|c|c|c|c|c|}
\hline \multirow{3}{*}{ Class } & \multicolumn{2}{|c|}{$\begin{array}{l}\text { Physical / semi- } \\
\text { physical channel } \\
\text { pattern discrimination }\end{array}$} & \multicolumn{5}{|c|}{ Empirical channel pattern discrimination } \\
\hline & Parker & $\begin{array}{l}\text { Crosato } \\
\text { and } \\
\text { Mosselman }\end{array}$ & Fredsøe & $\begin{array}{l}\text { Leopold } \\
\text { and } \\
\text { Wolman }\end{array}$ & $\begin{array}{c}\text { Eaton et } \\
\text { al. }\end{array}$ & Kleinha & $\begin{array}{l}\text { Is and Van den } \\
\text { Berg }\end{array}$ \\
\hline & \multicolumn{6}{|c|}{$\begin{array}{c}\text { Percentage of correctly classified above, below or in between } \\
\text { discriminators } \\
\text { (total number of rivers) }\end{array}$} & $\begin{array}{c}\text { Percentage } \\
\text { of correctly } \\
\text { classified above } \\
\text { lower limits } \\
\text { (total number } \\
\text { of rivers) }\end{array}$ \\
\hline No bars & - & $39(18)$ & - & - & - & $43(23)$ & - \\
\hline Scroll bars & - & $66(29)$ & - & - & - & $90(52)$ & $98(52)$ \\
\hline $\begin{array}{l}\text { Chute bars \& } \\
\text { Mod. braided }\end{array}$ & - & $78(23)$ & - & - & $6(34)$ & $76(37)$ & $95(37)$ \\
\hline Braided & - & $67(9)$ & - & - & $95(20)$ & $91(22)$ & $91(22)$ \\
\hline Single-thread & $100(62)$ & - & $82(66)$ & $79(97)$ & $26(72)$ & - & - \\
\hline Multi-thread & $57(14)$ & - & $100(15)$ & $76(29)$ & - & - & - \\
\hline Total & $92(76)$ & $63(79)$ & $85(81)$ & 79 (126) & $32(126)$ & 79 (134) & $96(111)$ \\
\hline$\kappa$ coefficient & 0.69 & 0.48 & 0.63 & 0.48 & 0.13 & 0.70 & 0.95 \\
\hline
\end{tabular}


Both physics-based and empirical channel pattern discriminators showed that the widthdepth ratio is an important discriminator factor, although it is not independent of actual channel pattern. This ratio is indirectly controlled by the floodplain properties such as bank strength (Schumm, 1960; Kleinhans, 2010). The relatively simple empirical channel pattern discriminator by Fredsøe (1978), using the width-depth ratio of 50 as discriminator, shows substantial agreement between the observed and discriminated channel patterns $(\kappa=0.63)$. This discriminator is relatively successful compared to the other empirical channel pattern discriminators, such as the original discriminator by Leopold and Wolman (1957), which shows moderate agreement $(\kappa=0.48)$. However, both discriminators discriminate just two channel pattern types. The channel pattern discriminator by Eaton et al. (2010) functions relatively well for braided rivers $(95 \%$ correct), but relatively poorly for lower-energy channel patterns and generally shows only slight agreement $(\kappa=0.13$, Table 5.1$)$. In their discriminator they introduced bank strength. Although we favour this addition of bank strength, we find the addition relatively impractical, because it was not included on the axes. Hence their discriminators do not have fixed positions and shift for each river reach depending on $\mu$ '.

Kleinhans and Van den Berg (2011) stated that their discriminators are defined as lower limits rather than true separation lines. This means that channels patterns can only exist above the associated lower limit, but channel patterns above that limit can also be of lower energetic regime (Figure 5.2d). For example, laterally stable rivers can exist in the field of meandering rivers with scroll bars, but not vice versa (Figure 5.2d). The empirical channel pattern discriminator by Kleinhans and Van den Berg (2011) performs best compared to other channel pattern discriminators (Table 5.1), when the discriminators by Kleinhans and Van den Berg (2011) are used as lower limits, with an almost perfect agreement $(\kappa=0.95)$. When the discriminators by Kleinhans and Van den Berg (2011) are interpreted as true separation lines (rather than lower boundaries), the channel pattern discrimination still performs relatively well for rivers with scroll bars $(90 \%$ correct), rivers with chutes and moderately braided rivers (76\% correct), and braided rivers (91\% correct). However, the channel pattern discrimination for rivers without bars, which are mostly sand-bed rivers $\left(\mathrm{D}_{50}: 0.1\right.$ to $\left.1 \mathrm{~mm}\right)$, is relatively poorly ( $43 \%$ correct). Overall the discriminated patterns show substantial agreement $(\kappa=0.70)$ with observations. 
This poor discrimination for the rivers without bars suggests that these rivers have the energetic potential for meandering and development of scroll bars, while they are in fact laterally stable. The poor discrimination success for low-energy sand-bed rivers is likely due to the effect of bank strength. Likewise, we expect that discriminative power for rivers with chute bars and moderately braided rivers will improve when the effect of bank strength is included, because rivers with a high silt-plus-clay fraction of the inner bank will not develop chutes (Kleinhans et al., 2018).

The empirical discriminator of Kleinhans and Van den Berg (2011) is relatively simple, requires a minimum number of channel pattern-independent parameters, discriminates more types of channel patterns than other existing empirical channel pattern discriminators, and yields results that are not inferior to existing physics-based and empirical discriminators of channel pattern. Hence, this channel pattern discriminator would be most suited to further develop as a channel pattern predictor. As discussed, the bank strength needs to be incorporated to further improve the channel pattern prediction, which will be discussed in the next section.

\subsection{Including bank strength in the empirical channel pattern prediction}

\subsubsection{Empirical relations between stream power and bank strength}

We use the average silt-plus-clay fraction of the river banks as a proxy for bank strength. In Figure 5.5 we plotted the channel patterns from our dataset in the parameter space of potential specific stream power and silt-plus-clay fraction of the river banks. Following our earlier work Candel et al. (in review) we added rivers with scroll bars and a tortuous channel pattern as an additional channel pattern, as discussed in Section 5.2.1. These rivers are more or less laterally stable due to self-constraining, although the scroll bars are evidence of minor, local lateral migration, because they are able to erode river banks that have a below-average bank strength (Candel et al., in review).

Most laterally stable rivers have a relatively high silt-plus-clay fraction and a low potential specific stream power (see Figure 5.5). Candel et al. (in review) used the empirical relation by Julian and Torres (2006) to discriminate self-constraining rivers from actively meandering rivers:

$$
\tau_{c}=0.1+0.18 S C+0.0028 S C^{2}-2.34 * 10^{-5} * S C^{3}
$$




\section{Chapter 5}

where $\tau_{c}$ is the critical shear stress $(\mathrm{Pa})$ needed to erode the silt-plus-clay fraction (SC, $\%$ ) in the banks. Julian and Torres (2006) showed that their empirical relation matches reported $\tau_{c}$ values from other bank-erosion studies (Dunn, 1959; Papanicolaou, 2001; Gaskin et al., 2003; Simon et al., 2003). Equation 5.12 was transformed to potential specific stream power (by Eq. A5.17 from Appendix 5), and plotted in Figure 5.5. We find that most rivers with scroll bars and a tortuous channel pattern, i.e. self-constraining rivers, plot below Eq. 5.12, and thus Eq. 5.12 represents a suitable discriminator between self-constraining and meandering rivers. However, rivers subject to self-constraining have scroll bars, indicating that lateral migration is still present on a small scale, hence they are different from laterally stable rivers. Based on our data, we determined the line that discriminates most laterally stable rivers from rivers subject to self-constraining. We assumed a linear relation between critical shear stress and silt-plus-clay fraction of river banks, following Mitchener and Torfs (1996), and defined the offset similar as in Eq. 5.12 .

$\tau_{c}=0.1 S C+0.1$

This Eq. 5.13 was transformed to potential specific stream power (by Eq. A5.17 from Appendix 5), and plotted in Figure 5.5. We refer to the transformed version of Eqs. 5.12 and 5.13 as the $\omega_{t m}$-discriminator and $\omega_{i t}$-discriminator, respectively, where subscript $t m$ refers to the tortuous-meandering pattern transition and subscript $i t$ to the inactivetortuous pattern transition. 
Predicting river channel pattern based on stream power, bed material and bank strength

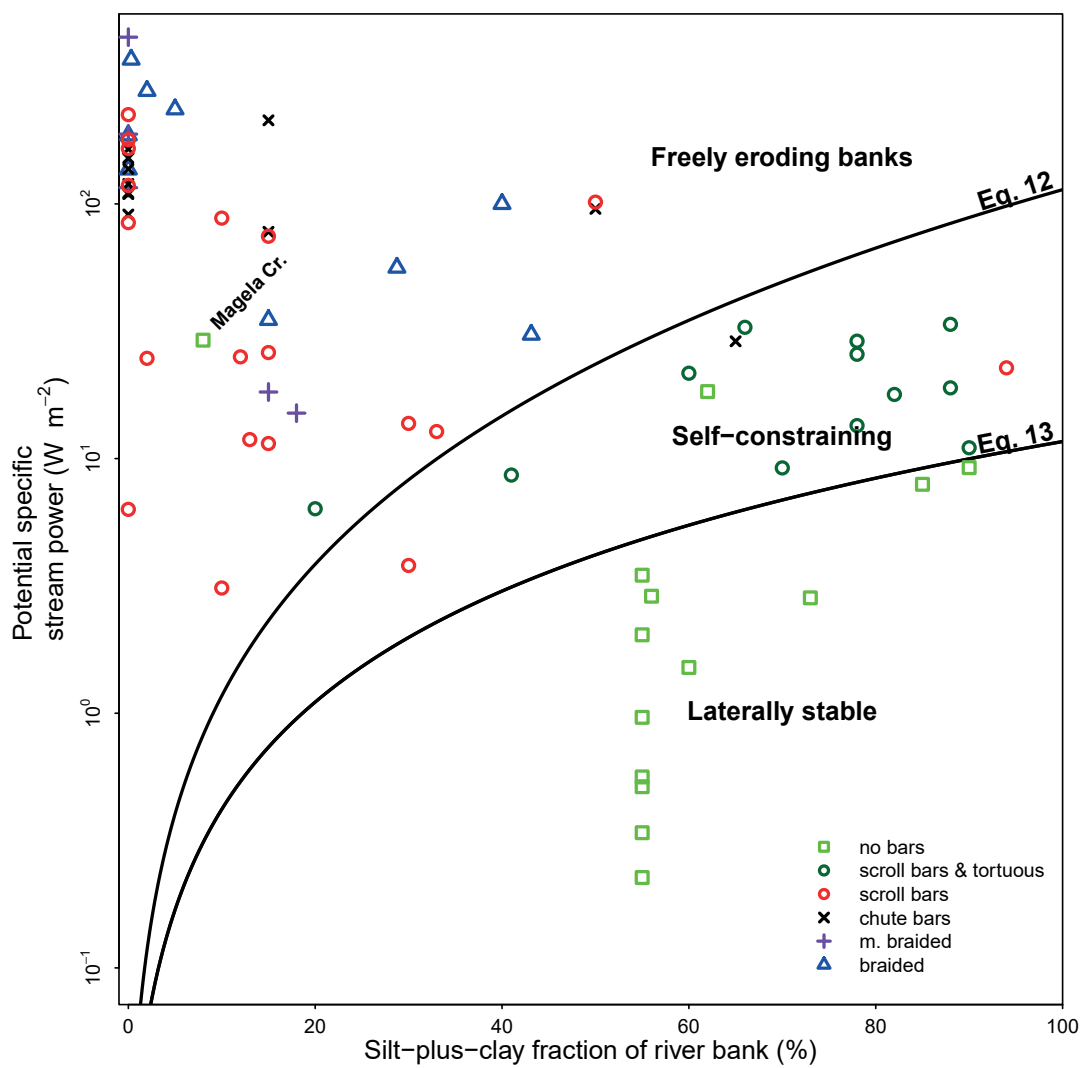

Figure 5.5 River patterns are plotted in the parameter space of potential specific stream power and siltplus-clay fraction of river banks. Lines indicate the critical potential specific stream power for bank erosion based on Julian and Torres (2006) (Eq. 5.12); and fitted from our own dataset (Eq. 5.13). Based on Candel et al. (in review), rivers with scroll bars were divided into two groups: self-constraining leading to tortuous channel pattern, and freely eroding banks leading to a normal meandering channel pattern (see Sect. 5.2.1). 


\subsubsection{New channel pattern predictor}

The original Kleinhans and Van den Berg (2011) discriminators were defined as lower limits above which the related channel pattern could exist. We previously argued that it should be possible to define true discriminators by including bank strength, and that the average silt-plus-clay fraction of river banks may provide a suitable parameter. Based on the described relations between the potential specific stream power and silt-plusclay fraction of river banks (Sect. 5.3.1), we now propose a three-dimensional channel pattern predictor that includes bank strength on a third axis. Our approach combines the channel pattern discriminator of Kleinhans and Van den Berg (2011) with the conceptual model of Eaton et al. (2010), and provides the first quantitative channel pattern predictor to include bank strength.

The original Kleinhans and Van den Berg discriminators (Eqs. 5.6 to 5.8; Figure 5.2d) are shown in a 3D-space (Figure 5.6), combined with the $\omega_{\mathrm{tm}}$-discriminator and $\omega_{\mathrm{it}}$ discriminator (Figure 5.5). Figures 5.7 and 5.8 include the river dataset and give a view of this $3 \mathrm{D}$-graph in a $2 \mathrm{D}$-plane, for the potential specific stream power versus the $\mathrm{D}_{50}$ (Figure 5.7), and the potential specific stream power versus the silt-plus-clay fraction (Figure 5.8). Laterally stable rivers commonly plot below the original $\omega_{\mathrm{i} \text { - }}$-discriminator (defined by Eq. 5.7). In the new diagram laterally stable rivers are expected to plot either below the $\omega_{\mathrm{ia}}$-discriminator or the $\omega_{\mathrm{it}}$-discriminator. For each combination of $\omega_{p o t}, \mathrm{D}_{50}$ and SC the $\omega_{\mathrm{ia}}$-discriminator intersects the $\omega_{\mathrm{it}}$-discriminator at a different point (Figures 5.6 to 5.8). The combination of $\mathrm{D}_{50}$ and SC determines which of these discriminators is relevant. As shown in Figures 5.6 to 5.8, the $\omega_{\mathrm{it}}$-discriminator is most important to discriminate laterally stable sand-bed rivers.

Rivers with scroll bars and tortuous channel patterns were defined as an additional group of channel patterns in Sect. 5.2.1, plotting in between the $\omega_{\mathrm{tm}}$-discriminator and $\omega_{\mathrm{ia}}$-discriminator (Figures 5.7 and 5.8). This group only exists for sand-bed rivers, because for these rivers the bank erosion is affected by the silt-plus-clay fraction of the river bank. In Figures 5.7 and 5.8 it can be seen how the addition of this group has changed the original diagram of Kleinhans and Van den Berg (2011) (Figure 5.2d). The original discriminators defined by Eqs. 5.6 to 5.8 are still relevant at low SC fractions (e.g. Figure $5.7 \mathrm{a}$ or $5.7 \mathrm{~b}$ ), but become irrelevant at high SC fractions (e.g. Figures 5.7c or $5.8 \mathrm{~d})$.

Meandering rivers with scroll bars originally plotted above the $\omega_{\mathrm{ia}}$-discriminator. In the 3D diagram (Figure 5.6), meandering rivers with scroll bars should plot above the $\omega_{\mathrm{tm}}$-discriminator and above the $\omega_{\mathrm{ia}}$-discriminator, and below the $\omega_{\mathrm{bm}}$-discriminator (Figures 5.6 to 5.8) to plot in the correct field. 


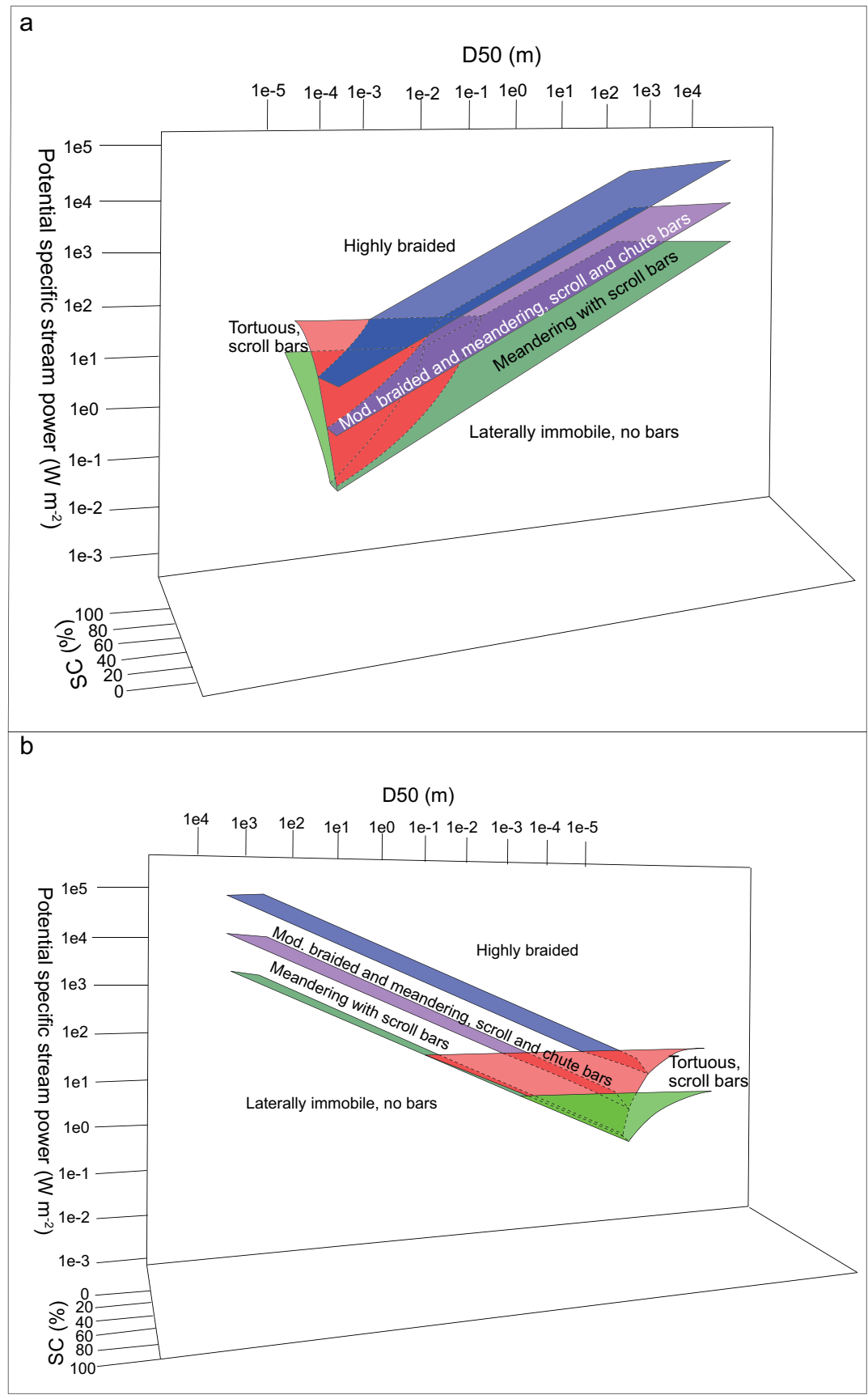

Figure 5.6 Empirical channel prediction as in Figure 5.2d, now including the bank strength on the third axis expressed as the silt-plus-clay fraction of the river banks (SC). Rivers with scroll bars and a tortuous channel pattern were added as an extra group. The graph is shown from two angles $(a, b)$ from which the discriminators can best be distinguished. The $3 \mathrm{D}$ image is available as a xls-file in the Supplementary Information of Candel et al. (submitted). 


\section{Chapter 5}

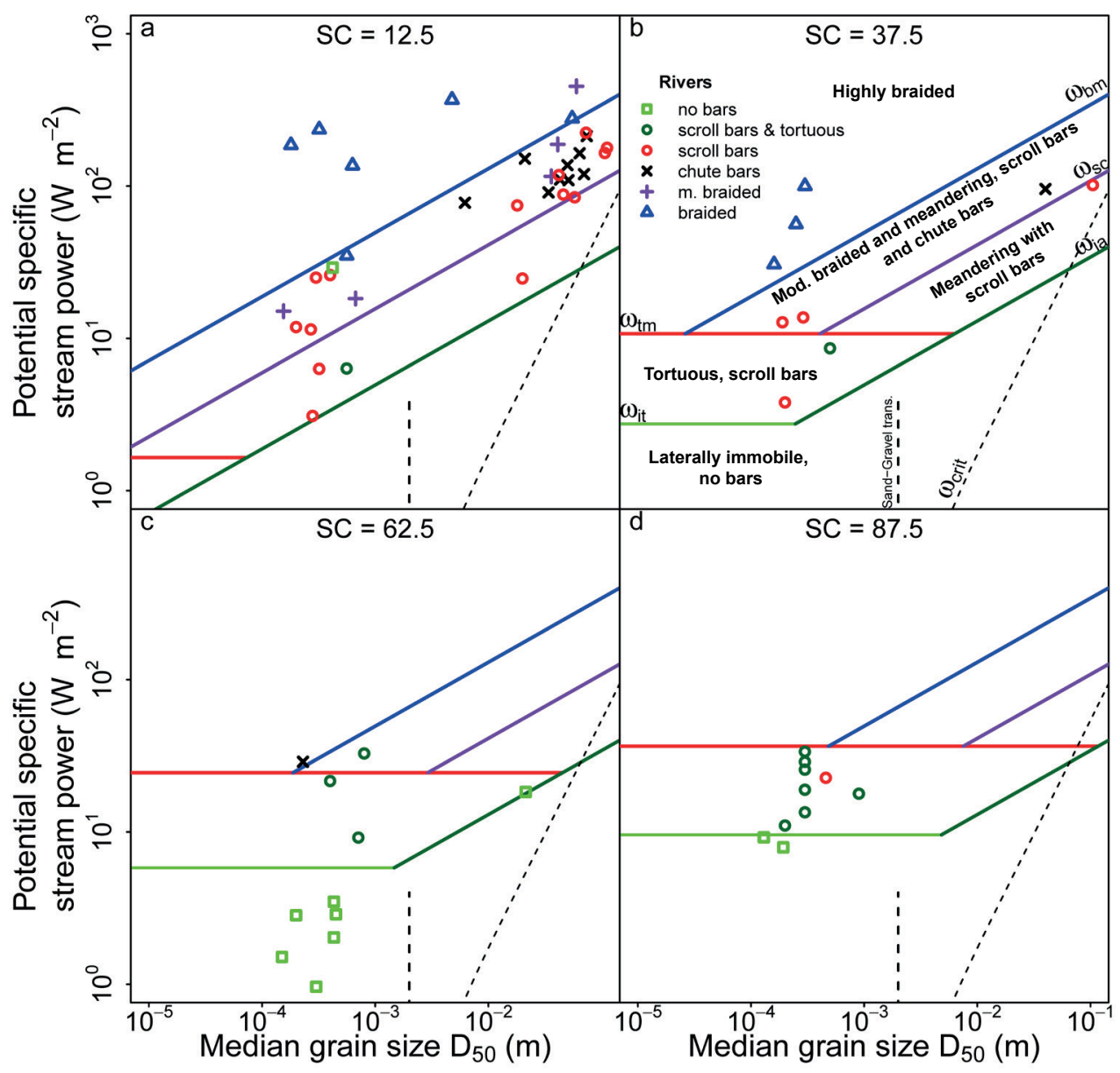

Figure 5.7 A 2D view of the 3D channel pattern predictor (Figure 5.6), showing the potential specific stream power versus the median bed grain size. The discriminators are plotted for silt-plus-clay percentages of river banks (SC) of $12.5 \%$ (a), $37.5 \%$ (b), $62.5 \%$ (c) and $87.5 \%$ (d). Data points are shown for rivers with silt-plus-clay fractions within $12.5 \%$ from this value (e.g. $25-50 \%$ for panel b). The legend, and description of the stability fields, discriminators and dashed lines are given in panel b. $\omega_{\text {crit }}$ is the critical stream power for motion of the bed sediment. 


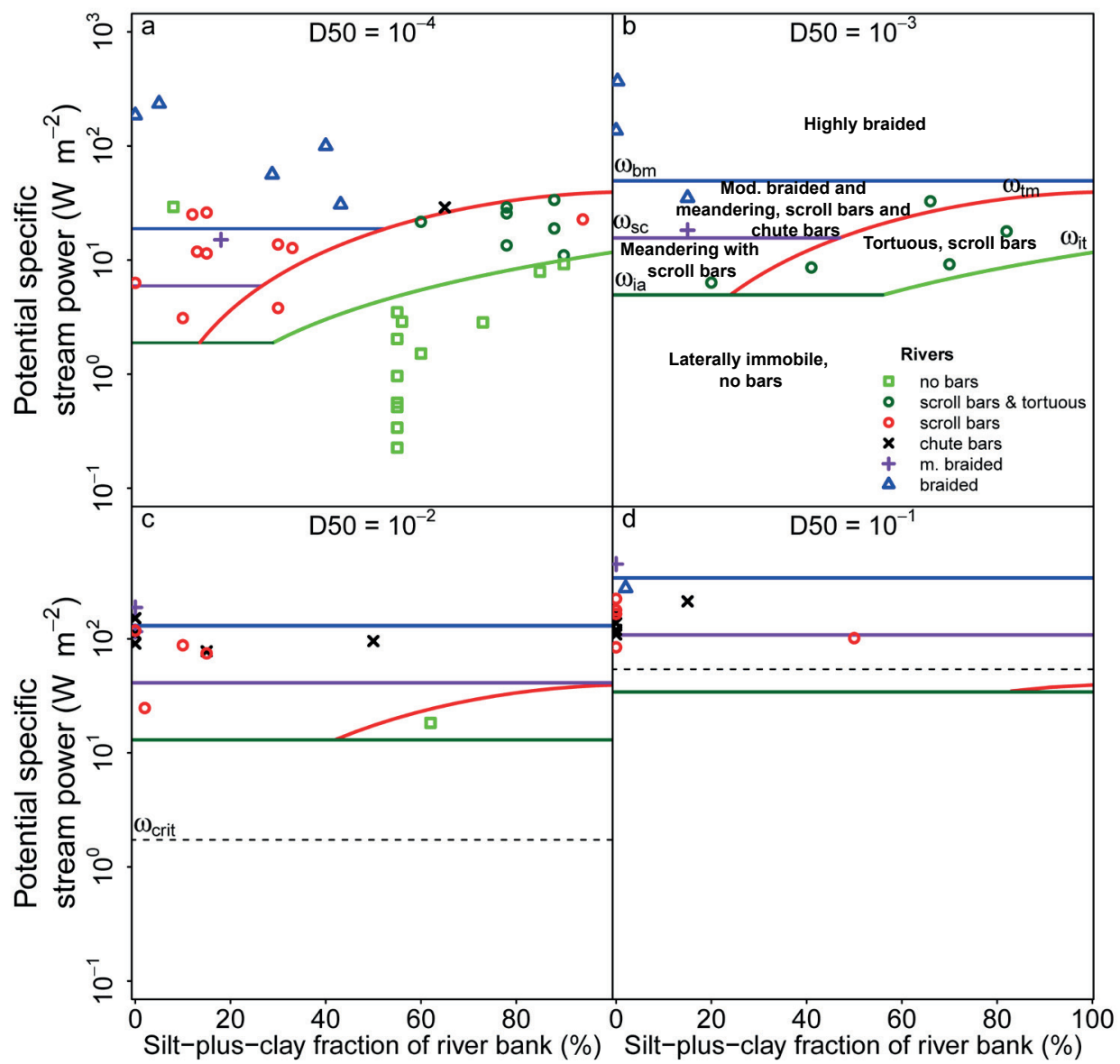

Figure 5.8 A 2D view of the 3D channel pattern predictor (Figure 5.6), showing the potential specific stream power versus the silt-plus-clay fraction of the river banks. The discriminators are plotted for a median bed grain size of $10^{-4} \mathrm{~m}(\mathrm{a}), 10^{-3} \mathrm{~m}(\mathrm{~b}), 10^{-2} \mathrm{~m}(\mathrm{c})$, and $10^{-1} \mathrm{~m}(\mathrm{~d})$. Data points are shown for rivers with bed material grain sizes within a factor 0.2 and 2 from this value (e.g. $5^{*} 10^{-4} \mathrm{~m}$ and $5^{*} 10^{-3} \mathrm{~m}$ for panel b). The legend, and description of the stability fields and discriminators are given in panel b. Dashed line indicates the critical stream power for motion of the bed sediment $\left(\omega_{\text {crit }}\right.$, see panel c). 


\subsection{Discussion}

In Table 5.2 the discrimination success percentages can be seen for the sub-dataset of 70 rivers for which the silt-plus-clay fraction of the banks is known. Overall, the new channel pattern predictor does not give a significant improvement: 61 out of 70 rivers were correctly plotted using Figure 5.6, compared to 59 out of 70 using Figure 5.2d. However, all river patterns now show a similar prediction success of 83 to $89 \%$, while before the meandering rivers with scroll bars could be well predicted $(94 \%)$, but the performance of laterally stable rivers was poor (57\%). The improvement of the channel pattern prediction is largest for laterally stable rivers, because bank strength is the most important parameter that can be related to the lateral activity of rivers (Schumm, 1963; Nanson and Croke, 1992; Candel et al., in review). Additionally, we introduced the extra class of river patterns, meandering rivers with scroll bars and a tortuous pattern, further specifying river channel patterns. The $\kappa$-coefficient increased from 0.77 to 0.84 , hence showing almost perfect agreement between the observed and predicted channel pattern. While pursuing perfect prediction is futile in view of lack of data and natural variability, the 3D diagram can be considered to be an improvement of the original channel pattern discriminator that was developed by Kleinhans and Van den Berg (2011), because of a relatively high prediction success for all channel pattern types.

The limitations of both empirical and physics-based channel pattern discriminators can be derived from the newly developed empirical channel pattern predictor in Figures 5.6 to 5.8. Based on the empirical and physics-based channel pattern discriminators in Figures $5.2 \mathrm{~d}$ and 5.4, respectively, it was shown that prediction of channel pattern for sand-bed rivers was poor because the effect of bank strength is not included. Hence, the applicability of existing channel pattern discriminators for channel pattern prediction is limited to fully alluvial rivers with erodible banks. This excludes a subset of sand-bed rivers that form cohesive, barely erodible banks. Bank strength has a strong control on the channel pattern for rivers with a low median bed grain size, and is thus the main limiting factor for the channel pattern discrimination (see Figure 5.8a). The gravelbed rivers could better be discriminated by the empirical and physics-based approach compared to the sand-bed rivers (Figures 5.2d and 5.4), here the critical stream power for motion of bed sediment forms the limitation factor (Figure 5.4). It could also be derived from Figure 5.8d that channel patterns are not limited by their silt-plus-clay fraction in the river banks, but rather by the critical stream power for movement of sediments. 
Predicting river channel pattern based on stream power, bed material and bank strength

Table 5.2 Percentages of correctly plotted channel patterns and $\kappa$ coefficient by using the discriminators by Kleinhans and Van den Berg (2011) as lower and upper limit (Figure 5.2d), and by the channel pattern predictor developed in Sect. 5.3.2 (Figures 5.6 to 5.8), for the 70 rivers of which the silt-plus-clay fraction of the river banks is known.

Rivers correctly plotted within the discriminators, having a lower and upper threshold

Class

Kleinhans and Van den Berg

(2011) (Figure 5.2d)
This chapter (Figures 5.6 to 5.8 )

Percentage \% (total number of rivers)

\begin{tabular}{lcc}
\hline No bars & $57(14)$ & $86(14)$ \\
Scroll bars and tortuous & - & $83(12)$ \\
Scroll bars & $94(31)$ & $89(19)$ \\
Chutes and Mod. braided & $88(16)$ & $88(16)$ \\
Braided & $89(9)$ & $89(9)$ \\
Total & $84(70)$ & $87(70)$ \\
$\kappa$ coefficient & 0.77 & 0.84 \\
\hline
\end{tabular}

Using the silt-plus-clay fraction of the river banks as measure of bank strength may be too simple. However, many studies have shown the strong relation between bank erosion and the silt-plus-clay fraction of the river bank, and river reaches with cohesive banks show very limited bank erosion (Hooke, 1980; Hudson and Kesel, 2000; Julian and Torres, 2006; Kleinhans et al., 2009). Consequently, river reaches are often laterally stable instead of meandering (Schumm, 1963; Hickin and Nanson, 1984; Nanson and Croke, 1992; Candel et al., in review), or are meandering instead of braided in settings where banks are relatively cohesive (Simpson and Smith, 2001; Kleinhans et al., 2018).

Hitherto, rivers in peatlands have not been included in any channel pattern discriminator, although these rivers can also be considered as alluvial rivers (see reasoning by Nanson, 2009). These rivers may be included when the bedload consists of clastic sediments instead of solely organic matter, and thus the median bed grain size can be determined. Rivers in peatlands are often laterally stable, because peat banks are relatively erosion resistant (Gradziński et al., 2003; Watters and Stanley, 2007; Nanson, 2010; Candel et al., 2017). It would be valuable to include peat banks on the axis of the silt-plus-clay fraction, representing the bank strength. This may be done by running experiments to 
find at which silt-plus-clay fraction the critical shear stress to erode a cohesive bank is equal to erode a peat bank.

Vegetation on the floodplain also affects the river morphology, and can even lead to different types of channel patterns than predicted (Hickin, 1984; Gibling and Davies, 2012; Gurnell, 2014; Corenblit et al., 2015). The presence of vegetation as patches on the floodplain stimulates the tendency to braid or develop a chute cut-off (Coulthard, 2005; Tal and Paola, 2010; Kleinhans et al., 2018), while dense vegetation cover will concentrate flow into a single meandering channel (Van Oorschot et al., 2016; Kleinhans et al., 2018) and could even result in a laterally stable channel with noncohesive banks as illustrated by the example of the Magela Creek in Australia (Tooth et al., 2008). This laterally stable river plots relatively far from the zone of laterally stable rivers in Figure 5.5. Tooth et al. (2008) argued that this river would be expected to be laterally active given the very low silt-plus-clay fraction of the river banks, but found that riparian vegetation plays a dominant role in this river system, creating an anabranching river system with laterally stable channels. The establishment of vegetation may be more difficult in cohesive sediments due to the higher penetration resistance, but tall vegetation may be uprooted more when growing on non-cohesive sediments (Edmaier et al., 2011). Vegetation can also capture fine sediments during overbank flooding and enhance the cohesivity of the inner-bend bank, which strongly reduces the chute cut-off frequency (Murray and Paola, 2003; Polvi et al., 2014; Kleinhans et al., 2018). Distinct patterns in the morphology of meandering rivers were found to relate to vegetation colonization, density and survival (Eekhout et al., 2014; Van Oorschot et al., 2016).

Including the complex relations between vegetation and river morphology is vital for our understanding of river morphodynamics, but out of the scope of developing a relatively simple channel pattern predictor as was one of the aims of this paper. The most important effect of vegetation on channel pattern is the effect on bank stability (Hickin, 1984; Corenblit et al., 2009; Van Oorschot et al., 2016). The way forward to further improve the channel pattern prediction is by incorporating this effect of vegetation in the bank erosion equations. Millar (2000) and Eaton and Giles (2009) showed with an analytical model that the minimum discharge needed to erode a river bank can considerably increase with the riparian vegetation rooting depth. They showed that incorporating the effect of vegetation on bank strength could be used to improve the discrimination between braided and meandering rivers. However, they used channel-dependent parameters in their discrimination, such as channel slope, making the discriminator unsuitable for the channel pattern prediction developed here. 
The biggest challenge exists in measuring the actual effect of vegetation on bank strength in the field (Hickin, 1984). Some studies used vegetation density as a proxy for the erosion-resistance (Millar, 2000; Julian and Torres, 2006). A disadvantage of this method is that plant characteristics, such as rooting architecture, largely differ between species and biogeographical regions (Preti et al., 2010; Evette et al., 2012). Remote sensing has great potential to map the vegetation type and density, and combine such efforts with studies that relate the above-ground biomass to the below-ground rooting density per biogeographical region, and translate this to bank shear strength (Micheli and Kirchner, 2002a; Wynn et al., 2004; Pollen, 2007; Van Iersel et al., 2018). For example, Micheli and Kirchner (2002b) developed methods to relate shear strength to the biomass and numbers of stems of vegetation.

The strength of the current channel pattern prediction is its relative simplicity. To be suitable for the prediction of channel patterns in practice, for example in river restoration projects, it is important to keep the channel pattern prediction relatively time and cost efficient (Makaske and Maas, 2015). The current method has a relatively high prediction success (Table 5.2), and uses relatively easily measurable parameters that are abundantly available for rivers and independent of the actual channel pattern and morphology.

As described in Sect. 5.1.1, an improved prediction of channel patterns is vital for river restoration projects, to predict channel pattern changes as a result of climate and land use change and to reconstruct environmental conditions based on channel patterns inferred from fluvial sedimentary archives. We supplemented the developed channel pattern predictor as an user-friendly tool, which can easily be applied to all alluvial river systems (see Supplementary Information by Candel et al. (submitted)). We also included the option to add uncertainty to the input parameters: effective channel-forming discharge, valley slope, median bed grain size and the silt-plus-clay fraction of river banks. More details on these calculations can be found in the Supplementary Information by Candel et al. (submitted). 


\subsection{Conclusions}

In this study we elaborated upon existing channel pattern discriminators and their potential to be used as predictors. Our main conclusions are:

- Most frequently-used physics-based and empirical channel pattern discriminators do not have high success rates in discriminating channel patterns for sand-bed rivers, because floodplain properties are not included.

- River channel pattern discriminators have been used to predict channel pattern, while they often use morphometric parameters, and parameters dependent of channel pattern and morphology.

- The success rate of the channel pattern prediction improved by adding an additional channel pattern class of rivers with scroll bars and tortuous channel patterns. These rivers are self-constraining and have inhibited river mobility due to relatively erosion-resistant deposits in the floodplain, and therefore differ from meandering rivers with scroll bars and a regular meandering channel pattern (Candel et al., in review).

- The success rate of the channel pattern prediction improved by adding bank strength, using the average silt-plus-clay fraction as a proxy, to the set of processbased parameters independent of channel pattern (i.e. potential specific stream power and median bed grain size). The improvement was largest for sand-bed rivers.

\section{Acknowledgments}

The authors would like to thank Gerard Heuvelink for his help with the statistical methods. 



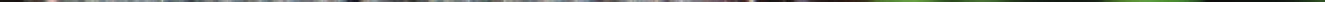




\section{Chapter 6}

\section{Synthesis and conclusions}





\subsection{Introduction}

In Chapter 1, I defined three objectives regarding the typology, key forming factors and prediction of low-energy river channel patterns and dynamics (see Sect. 1.3). The main motivation for these research objectives was to enhance the knowledge-based restoration of low-energy rivers. The case study rivers described in Chapters 2 to 4 have different floodplain sediment compositions, a peaty (Ch. 2), heterogeneous (Ch. 3) and sandy floodplain (Ch. 4), and different morphologies. In Section 6.2, I define a typology of low-energy rivers based on the case studies, which improves existing characterizations of low-energy rivers. This typology combines both the channel pattern and floodplain sediment composition of these river systems. To enable quick comparison between the case studies and river types, the main elements are summarised in Table 6.1 and schematic diagrams in Figure 6.1. Comparison of the different types of low-energy rivers (Sect. 6.2) and their formation (Sect. 6.3) sheds light on what key forming factors determine the channel pattern of low-energy rivers (Sect. 6.4). I elaborate upon the key forming factors by applying the channel pattern predictor that was developed in Chapter 5 throughout Section 6.4. Chapter 5 can already partly be considered as a synthesizing chapter, therefore I only briefly discuss the channel pattern predictor in this chapter. In Sect. 6.5, I reflect on the extrapolation of this research to different temporal, discharge and grain size scales. Based on these first sections I elaborate upon the practical implications (Sect. 6.6), and finish with the main conclusions (Sect. 6.7) and recommendations for future research (Sect. 6.8).

\subsection{Typology of low-energy rivers}

\subsubsection{River types}

In Section 1.2.2 I discussed the state-of-the-art geomorphological classification of singlechannel, alluvial low-energy rivers. Hitherto, low-energy rivers have been classified as either meandering (river type 1; Table 6.1 and Figure 6.1a) or laterally stable (river type 2; Table 6.1 and Figure $6.1 \mathrm{~b}$ ), because they are either able or unable to erode their floodplain, respectively (Nanson and Croke, 1992). Both low-energy river types are documented in Chapter 4, where the Overijsselse Vecht was relatively laterally stable (river type 2) prior to its meandering phase (river type 1). In this thesis I showed that this existing twofold classification ignores two other low-energy river types that are morphologically distinct. 
Rivers in heterogeneous floodplains alternately laterally migrate where the floodplain consists of unconsolidated sediments, or are laterally stable where the floodplain is relatively cohesive or organic (Ch. 3), resulting in self-constraining rivers (river type 3; Table 6.1 and Figure 6.1c). Rivers in peatlands were commonly also classified as laterally stable rivers, because peat forms relatively erosion-resistant floodplains (Nanson, 2009). However, the distinct channel pattern of rivers in peat-filled valleys results from oblique aggradation (Ch. 2), which I refer to as obliquely aggrading rivers (river type 4; Table 6.1 and Figure 6.1d). In the next section, I describe the main morphological characteristics of these low-energy river types using Table 6.1 and Figure 6.1, based on the case studies of Chapters 2 to 4 .

\subsubsection{Channel and floodplain morphology}

Meandering rivers (river type 1) have a classical meandering channel pattern with relatively smooth bends (Figure 6.1a, Chapters 4 and 5). This river type has the highest width-depth ratio of all river types, with a width-depth ratio of ca. 25 in case of the Overijsselse Vecht. This river type laterally migrates, and thus develops a scrolled floodplain, with levees on top of the scroll bars and along the channel. Oxbow channels are present in the floodplain, witnessing of cut-off meander bends.

The channel pattern of laterally stable rivers (river type 2 ) shows large similarities with the laterally stable channels on the intertidal mudflat (Figure 6.1b). Both channel patterns consist of straight to irregular sinuous patterns, with occasional sharp bends with outerbank embayments (Kleinhans et al., 2009; Kleinhans et al., in review). The width-depth ratio of laterally stable river is generally lower than 10 (see Figure 5.4), with a widthdepth ratio of 8 for the case study river (Table 6.1). The channel pattern is completely laterally stable, despite a few local lateral channel displacements of sharp river bends (Chapter 4) (Kleinhans et al., 2009). No scroll bars are present, natural levees are present along the channel, and thick successions of cohesive overbank deposits dominate the floodplain. Oxbow channels are rare, and only form due to local perturbations (Sect. 4.5.1). I did not extensively study the laterally stable river type, because only two small palaeochannel reaches were preserved in the Overijsselse Vecht river. Nevertheless, examples of other laterally stable rivers, e.g. the Barwon River (Woodyer et al., 1979) or laterally stable rivers in the UK (Brown and Keough, 1992) support the characterization of this river type, and this river type was extensively described by the classification by Nanson and Croke (1992). 
a

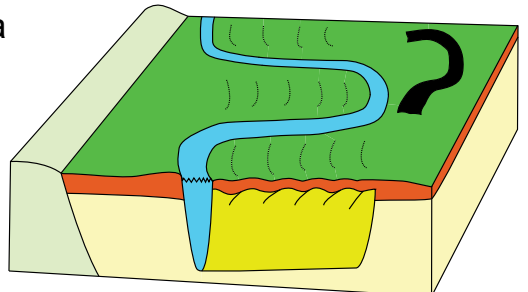

C

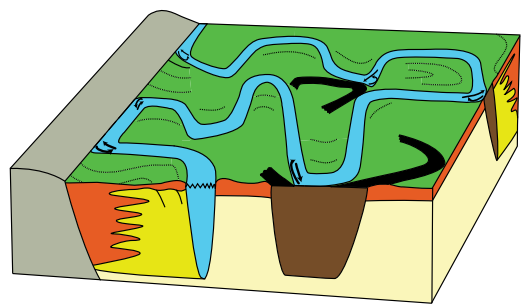

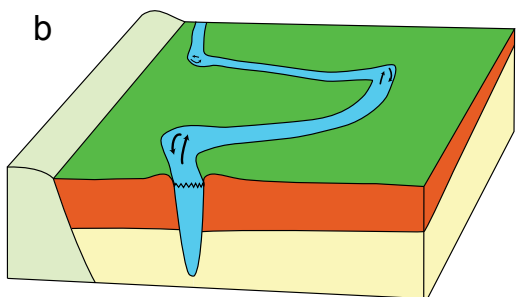

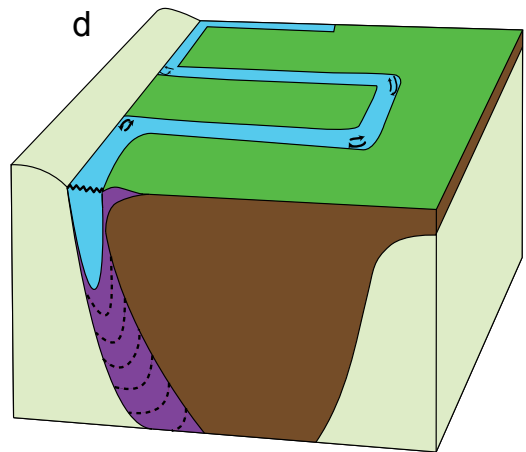

\section{Legend}

Valley-fill

$\square$ Sand / Loamy sand

Sand

Loamy sand / sandy loam / sandy clay loam

Valley-side

$\square$ Sandy

Sandy clay loam / silty clay loam

/ silty clay loam / clay loam / clay

Sandy peat / peaty sand

Peat

Figure 6.1 Schematic diagram showing different types of low-energy river patterns and associated floodplain sediment composition; a) Type 1: a meandering river with scroll bars in a relatively sandy floodplain, b) Type 2: a laterally stable river in a relatively cohesive floodplain, c) Type 3: a self-constraining river in a heterogeneous floodplain, d) Type 4: an obliquely aggrading river in a peat-filled valley. Vertical scale is exaggerated. See Table 6.1 for comparison of some morphological characteristics.

Self-constraining rivers (river type 3) consist of a tortuous channel pattern of sharp bends with variable size and irregular changes in channel direction (see Ch. 3). The width-depth ratio is low, 3 to 5 in case of the Dommel River (Table 6.1). 


\section{Chapter 6}

Table 6.1 Comparison of the low-energy river types. Data is based on the case study rivers in Chapter 2 to 4 .

\begin{tabular}{|c|c|c|c|c|}
\hline & Type 1 & Type 2 & Type 3 & Type 4 \\
\hline Typology & Meandering & Laterally stable & Self-constraining & Obliquely aggrading \\
\hline $\begin{array}{l}\text { Schematic } \\
\text { diagram }\end{array}$ & Figure $4 \mathrm{a}$ & Figure $4 \mathrm{~b}$ & Figure $4 \mathrm{c}$ & Figure 4d \\
\hline Case study river & $\begin{array}{l}\text { Overijsselse } \\
\text { Vecht: } \\
\text { meandering } \\
\text { phase }\end{array}$ & $\begin{array}{c}\text { Overijsselse } \\
\text { Vecht: laterally } \\
\text { stable phase }\end{array}$ & Dommel River & Drentsche Aa \\
\hline Chapter & 4 & 4 & 3 & 2 \\
\hline $\begin{array}{l}\text { Valley gradient } \\
\left(\mathrm{m} \mathrm{km}^{-1}\right)\end{array}$ & \multicolumn{2}{|c|}{$0.14-0.17$} & 0.33 & 0.29 \\
\hline $\begin{array}{l}\text { Potential specific } \\
\text { stream power }\end{array}$ & $2.3-4.8$ & $1.4-2.0$ & 2.8 & 2.5 \\
\hline$\left(\mathrm{W} \mathrm{m}^{-2}\right)$ & & & & \\
\hline Oxbow channels & Abundant & Few & Abundant & None \\
\hline Channel pattern & $\begin{array}{l}\text { Meandering with } \\
\text { scrolls, smooth } \\
\text { bends }\end{array}$ & $\begin{array}{l}\text { Straight to } \\
\text { irregular sinuous, } \\
\text { sharp bends, } \\
\text { outer-bend } \\
\text { embayments }\end{array}$ & $\begin{array}{l}\text { Tortuous; sharp } \\
\text { bends with } \\
\text { variable size, } \\
\text { abrupt irregular } \\
\text { changes in channel } \\
\text { direction }\end{array}$ & $\begin{array}{l}\text { Rectangular bends } \\
\text { and straight reaches }\end{array}$ \\
\hline $\begin{array}{l}\text { Dominant } \\
\text { channel pattern } \\
\text { forming process }\end{array}$ & Meandering & $\begin{array}{l}\text { Inheritance / } \\
\text { Perturbations }\end{array}$ & Self-constraining & $\begin{array}{c}\text { Inheritance / Oblique } \\
\text { aggradation }\end{array}$ \\
\hline $\begin{array}{l}\text { Width-depth } \\
\text { ratio }\end{array}$ & 25 & 8 & $3-5$ & $3-5$ \\
\hline Sharp bends & Some & Yes, occasionally & Yes, many & Yes, many \\
\hline Banks & $\begin{array}{c}\text { Sandy, } \\
\text { gradual inner } \\
\text { and steep outer }\end{array}$ & $\begin{array}{l}\text { Sandy and loamy, } \\
\text { steep }\end{array}$ & $\begin{array}{l}\text { Heterogeneous, } \\
\text { steep }\end{array}$ & $\begin{array}{l}\text { Peaty, } \\
\text { Steep }\end{array}$ \\
\hline $\begin{array}{l}\text { Scroll bars and } \\
\text { natural levees }\end{array}$ & $\begin{array}{l}\text { Yes, natural } \\
\text { levees on top of } \\
\text { scroll bars and } \\
\text { outer bank }\end{array}$ & $\begin{array}{l}\text { No scroll bars, } \\
\text { natural levees } \\
\text { along the channel }\end{array}$ & $\begin{array}{l}\text { Yes, natural } \\
\text { levees on top of } \\
\text { (small) scroll bars } \\
\text { and outer bank, } \\
\text { and along stable } \\
\text { channel reaches }\end{array}$ & $\begin{array}{c}\text { No scroll bars, small } \\
\text { natural levees along } \\
\text { the channel }\end{array}$ \\
\hline $\begin{array}{l}\text { Bed material, } D_{50} \\
(\mathrm{~mm})\end{array}$ & Sand, 0.28-0.33 & Sand, $0.11-0.35$ & Sand, $0.15-0.25$ & Organic sand, - \\
\hline
\end{tabular}


This river type develops small scroll bars on the inside of secondary bends, and distinct natural levees where the river has been laterally stable for a significant amount of time (Figure 6.1c). Cohesive and organic counterpoint deposits are abundantly present in the floodplain. Oxbow channels are also abundantly present in floodplains of selfconstraining rivers (Ch. 3), which fill in with fine sediments and organics, because diversion angles to the cut-off channel are high (Constantine et al., 2010). This river type shows large similarities to meandering and laterally stable rivers (Table 6.1), because oxbow channels and scroll bars are present in the floodplain similar to meandering rivers, and the river pattern occasionally consists of sharp bends similar to laterally stable rivers.

Obliquely aggrading rivers (river type 4) consist of rectangular bends with straight reaches in between (Figure 6.1d). The width-depth ratio is low, 3 to 5 in case of the Drentsche Aa (Table 6.1). River type 4 does not have scroll bars, because lateral migration only occurs as part of the oblique aggradation. Natural levees are small and poorly developed, because the river channel transports limited clastic sediments. Oxbow channels are absent. The floodplain material almost entirely consists of peat. The outer banks may consist of the sandy valley side that the channel adheres to (Figure 6.1d), because this valley side is relatively easily erodible compared to the peaty valley fill (Ch. 2).

\subsection{Channel pattern formation}

In this section I describe how the studied low-energy rivers formed their channel pattern with time. Here I sketch the initial morphological conditions from which the channel patterns of the case studies developed. These examples provide a base for the description of the key forming factors in Sect. 6.4. Figure 6.2 shows the interpretation of channel pattern, floodplain or channel belt width and lateral activity with time for the studied river reaches in this thesis since the Late Pleniglacial. 


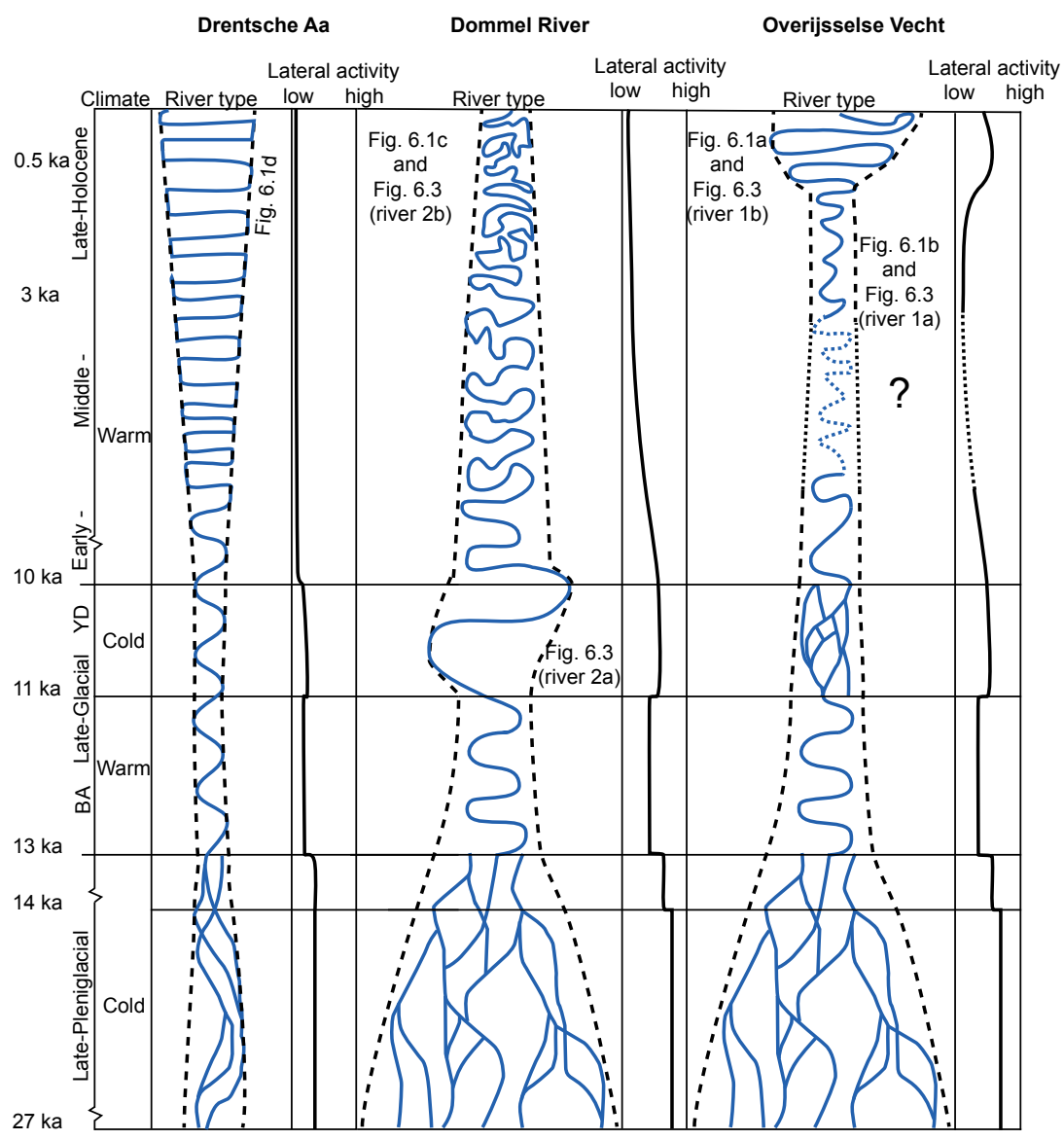

Figure 6.2 Compilation of river type, floodplain width (Drentsche Aa) or channel belt width (Dommel River and Overijsselse Vecht) and lateral activity with time as interpreted for the studied rivers. Interpretations prior to and during the Early Holocene are based on De Gans (1981) for the Drentsche Aa, Bisschops (1973) for the Dommel River and Huisink (2000) for the Overijsselse Vecht.

All three rivers were braided river systems fed by snow-meltwater during the cold climate of the Late Pleniglacial. The Dommel River and Overijsselse Vecht were highly braided on a wide floodplain (Bisschops, 1973; Huisink, 2000), while the Drentsche Aa was relatively constrained within the valley that had formed as a result of deep incision during the Early Pleniglacial, which was partly filling up with fluvial-aeolian sediments during the Late Pleniglacial (De Gans, 1981). This period was followed by the warmer Bølling-Allerød interstadial during the Late Glacial, when stream power decreased and the Dommel and Overijsselse Vecht changed into moderately braided and meandering rivers (Bisschops, 1973; Huisink, 2000). Probably, the first peat started to grow in the Drentsche Aa valley system during this period, given the oldest radiocarbon date that 
almost falls in the Bølling-Allerød interstadial, while it was not taken yet from the valley bottom (Chapter 2) (Makaske et al., 2015). No information on channel pattern of the Drentsche Aa is available from this period (De Gans, 1981), but following upon the incisional phase, the channel pattern was probably a single-thread river that became constrained in the peaty floodplain. During the consecutive colder period, the Younger Dryas, the Overijsselse Vecht started braiding again as a result of increased stream power, while the Dommel River became a relatively large, incising meandering river that left a well-expressed bluff along the edge of the valley. This is the start of the Holocene pattern formation of these river systems, and these initial conditions are important for the later development of these rivers.

The Drentsche Aa enters the Holocene within a relatively deep, narrow valley and as peat is growing since the Bølling-Allerød interstadial, the sandy valley side is the only easily erodible feature. The channel pattern develops along the valley sides (Chapter 2) into a relatively rectangular channel pattern with straight reaches in between the bends (river type 4, Figure 6.1d). The floodplain of the river widens as a result of peat growth in this $\mathrm{V}$-shaped valley. Adherence of river reaches to the valley sides, in combination with floodplain widening, results in a river that is stretched out resulting in increased sinuosity.

The Dommel River starts within a wide valley, of which the valley sides consist of the relatively erosion-resistant Liempde Member of the Boxtel Formation (i.e. 'Brabant loam') (Vink, 1949; Schokker, 2003). The Late-Glacial meanders, which are located on the margins of the valley, fill up with peat and form erosion-resistant deposits as well (Chapter 3) (Janssen, 1972). The channel belt narrowed with time, and the river constrained its planform within its self-formed heterogeneous deposits (river type 3, Figure 6.1c).

The Overijsselse Vecht River starts the Holocene as a meandering river, probably originating from the main channel of the Late-Glacial braided river system (Huisink, 2000). The river is located in relatively unconsolidated sediments, however, it did not have a very wide floodplain since the Late Glacial, possibly due to bank stabilisation related to vegetation (Huisink, 2000; Wolfert and Maas, 2007), indicating that the river was or became relatively laterally stable from then on. The relatively sharp bend that was found of the laterally stable phase during the Late Holocene lacked scroll bars, and its past lateral migration was very limited as revealed by OSL datings (Ch. 4). Therefore I expect that the river was laterally stable (river type 2, Figure 6.1b) during a large part of the Holocene (Figure 6.2), similar to many other low-energy river systems in northwestern Europe (Notebaert and Verstraeten, 2010; Brown et al., 2018). The river changed from laterally stable to meandering ca. 500 to 600 years ago, and caused 
excessive, but isolated meander bends that laterally migrated with rates of 2 to $3 \mathrm{~m}$ $\mathrm{yr}^{-1}$ (Quik and Wallinga, 2018). This laterally active phase (river type 1, Figure 6.1a) removed most of the Early and Middle Holocene sediments creating a hiatus in the floodplain depositional record (Figure 6.2).

The pre-Holocene river types determine the initial conditions for the channel pattern that develops during the Holocene, such as the initial floodplain topography, floodplain composition and valley side position. These initial factors determine the initial channel path of the river, which may change relatively fast when the river is laterally active (river types 1 and 3), while they may remain to exist for a significant amount of time when the river is relatively laterally stable (river types 2 and 4). The river activity is partly determined by the catchment area, which determines the river discharge regime, valley slope and source for the sediment transport. These factors determine whether sufficient stream power is available to erode the floodplain and valley side, and whether the floodplain composition may change with time. Hence, the initial conditions are of great influence on the key forming factors.

\subsection{Key forming factors}

Kleinhans (2010) described that channel pattern formation of rivers mostly depends upon the balance between stream power and bank strength. In this thesis I show that both factors can vary spatially and temporarily, and that subtle changes of this balance affect the channel pattern of low-energy rivers, because this balance determines whether low-energy river reaches are laterally stable or active. Here I elaborate upon these key forming factors, their changes and their effect on the channel pattern formation and lateral activity of low-energy channel patterns. I apply the channel pattern predictor that was developed in Chapter 5 to illustrate some of these effects, and also include examples of other river types with larger stream power.

\subsubsection{Stream power}

In Chapter 5, I describe that the stream power is determined by the river gradient and discharge. The river gradient is determined by the local geology, sea level and tectonics (Vandenberghe, 1995; Holbrook and Schumm, 1999), and commonly varies within a river, and may also change with time (e.g. Woolderink et al., 2019). The discharge varies with time, both on the long-term (in decades to centuries) and short-term (within a year). Because most rivers are in morphological equilibrium with the discharge variation on the short term, the short-term variation commonly does not result in changes of channel pattern (Brierley and Fryirs, 2000; Kleinhans, 2010). Consequently, the effective 
channel-forming discharge was used, to refer to the discharge that is morphologically most important, in Chapters 3 to 5 and used in the channel pattern predictor. This channel-forming discharge commonly has a recurrence interval of 1 to 2 years (Wolman and Miller, 1960; Dury, 1973).

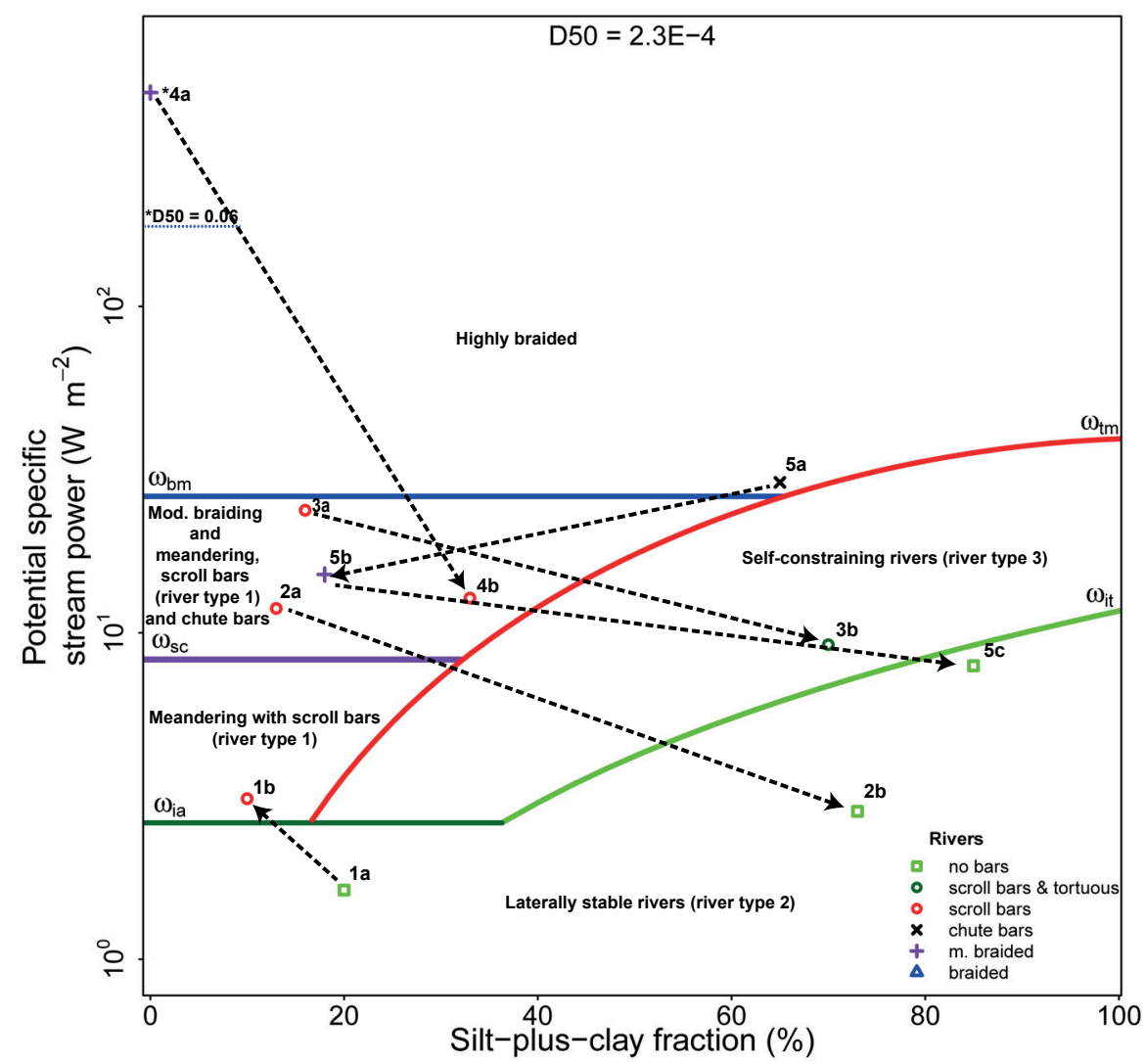

Figure 6.3 A 2D view of the 3D stability diagram as presented in Chapter 5, showing the potential specific stream power versus the silt-plus-clay fraction of the river banks. The river types match the river types in Figure 6.1a-c. The discriminators are plotted for a median bed grain size of $0.23 \mathrm{~mm}$, which is the median of the river reaches shown, which are all sand-bed and have median bed grain sizes within a relatively small range (see Figure 6.4). River reach $4 \mathrm{a}$ forms an exception, which is a gravel-bed river with a median bed grain size of $60 \mathrm{~mm}$ (see Figure 6.4). The upper discriminator for river reach $4 \mathrm{a}$ is separately shown. Differences in channel pattern in space or time are illustrated in this figure, of which the numbers correspond to the rivers referred to in the main text: 1) Overijsselse Vecht, 2) Dommel River, 3) Murrumbidgee River, 4) Athabasca River, 5) Milk River. 
Stream power variation on the long-term affects the channel pattern, as has been reported in Chapter 4. The channel pattern predictor confirmed that an increase of stream power in the Overijsselse Vecht was a plausible cause of the channel pattern change from a laterally stable river to a meandering river ca. 500 years ago. This channel pattern change is illustrated in the newly developed channel pattern predictor based on Chapter 5 (see Figures 6.3 and 6.4, river 1 ).

A decrease of stream power can also result in a channel pattern change, for example during glacial-interglacial transitions. The current Dommel River has a 12 to 15 times lower effective channel-forming discharge than the Late-Glacial Dommel River, which led to a channel pattern change from a meandering river with scroll bars to a selfconstraining river, and finally to a laterally stable river (Chapter 3, Figures 6.3 and 6.4, river 2). A similar drop of stream power occurred for the Murrumbidgee River from the Late Glacial to the Holocene (Figures 6.3 and 6.4, river 3) (Schumm, 1968). A channel pattern change back to a meandering river requires a stream power increase, but to a higher energy level than it had before due to the resilience of the system (Chapter 3). The increased silt-plus-clay fraction of the river banks resulted in a higher critical stream power that is needed to erode the floodplain, because the erosion-resistance increased. Figures 3.13 and 6.4 illustrate how this boundary increased as a result of more cohesive river banks. 


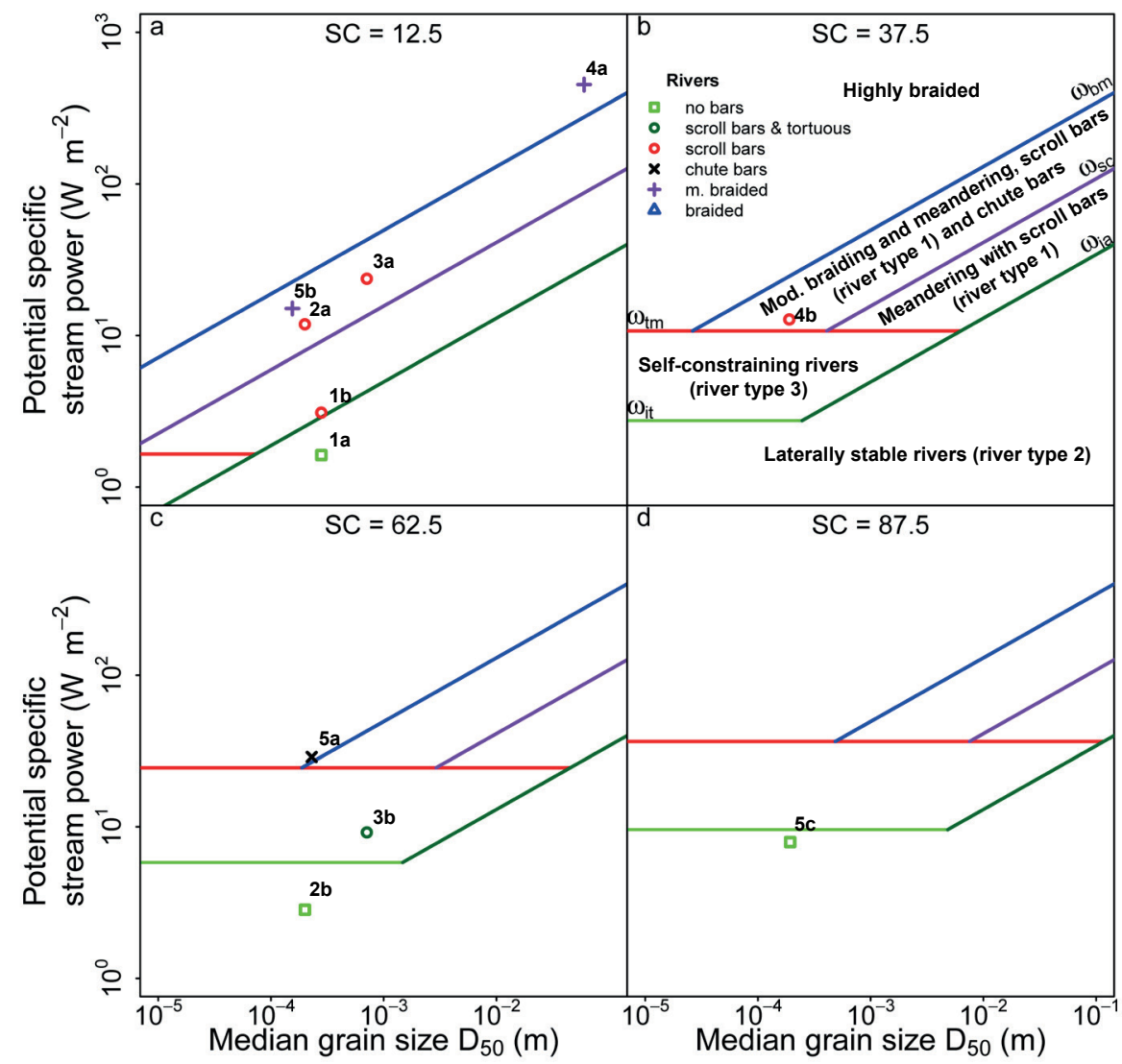

Figure 6.4 A 2D view of the 3D stability diagram as presented in Chapter 5 , showing the potential specific stream power versus the median bed grain size. The discriminators are plotted for silt-plus-clay percentages of river banks (SC) of $12.5 \%$ (a), 37.5\% (b), $62.5 \%$ (c) and $87.5 \%$ (d). Data points are shown for rivers with silt-plus-clay fractions within $12.5 \%$ from this value (e.g. $25-50 \%$ for panel b). The legend, and description of the stability fields and discriminators are given in panel $b$. The river types match the river types in Figure 6.1a-c. Numbers correspond to the rivers referred to in the main text: 1) Overijsselse Vecht, 2) Dommel River, 3) Murrumbidgee River, 4) Athabasca River, 5) Milk River.

Stream power also varies spatially. Between channel reaches the stream power varies because of different gradients, or where discharges increase with more tributaries joining downstream or decrease due to a bifurcation. This variation explains the longitudinal variation of channel pattern within rivers. For example, in Chapter 4 the large meanders of the Overijsselse Vecht were studied, which are located at the relative downstream end of the river. Further upstream of the case study reach (Ch. 4), lateral migration rates were lower and the river channel had a lower lateral activity, partly because of a lower effective channel-forming discharge (Wolfert and Maas, 2007). The Athabasca river in Canada shows the opposite, where the most active part is upstream where it is a moderately 
braided river, but changes into a meandering river further downstream, partly as a result of a decreasing valley slope (shown in Figures 6.3 and 6.4, river 4) (Doyle, 1977). Before channelization, the Rhine river was also meandering in the eastern (upstream) part of The Netherlands and laterally stable in the western part (downstream, Figure 1.5), because the gradient decreased from ca. $15 \mathrm{~cm} \mathrm{~km}^{-1}$ to ca. $2.5 \mathrm{~cm} \mathrm{~km}^{-1}$, and banks became more organic and cohesive further downstream (Van Dijk, 1991; Törnqvist, 1993; Berendsen and Stouthamer, 2000).

Stream power can also vary locally on a relatively small scale within the channel. Kleinhans et al. (2009) showed how flow separation forms in laterally stable channels on a cohesive intertidal mud flat. Flow separation is enhanced in sharp bends as a result of flow inertia. The main flow is then projected on the outer bends, resulting in a local displacement of the channel (Ferguson et al., 2003; Kleinhans et al., 2009; Blanckaert et al., 2013). This same process may also occur as a result of a perturbation, for example tree fall, which causes the flow to diverge and concentrate its energy on the river bank (Geertsema et al., in review).

Sharp bends in low-energy rivers seem to be the rule rather than the exception (see Chapters 2 to 4, Sect. 6.2) (Kleinhans et al., in review). Hence, flow separation is an important element of the morphodynamics of low-energy rivers (Vermeulen et al., 2015; Geertsema et al., submitted) (Figure 6.1), leading to variation in stream power within the channel. Flow separation may lead to erosion of banks in low-energy rivers when the flow impinges directly on a bank that is relatively easily erodible. The point of impingement may be towards the inner bend upstream of the meander apex (Hickin, 1978; Hodskinson and Ferguson, 1998; Blanckaert et al., 2013), or to the outer bank downstream of the bend apex (Blanckaert et al., 2013). Ghinassi et al. (2016) showed that this point of impingement may shift as a result of changing river discharges. The outer bank that normally is eroded near the bend apex in classical meandering rivers, is often protected in low-energy rivers from erosion by the counter-rotating cells that form zones of low-energy flow (Blanckaert, 2011). Within these low-energetic zones, counterpoint deposits may form (Chapter 3) (Makaske and Weerts, 2005; Smith et al., 2009). Such flow separation is also common in peatland rivers (Nanson, 2010; Nanson and Cohen, 2014). In the Drentsche Aa stream (Chapter 2) flow separation was observed in the very sharp bends during the fieldwork, with counter-rotating flows at the water surface. The sandy banks are slowly eroded by the impinging flow, while the peat banks resist because of their strength. Consequently, the flow patterns in most low-energy river types (river types 2 to 4 ) deviate from classical meandering rivers with regular gently curved bends (river type 1). 


\subsubsection{Bank strength}

Bank strength is determined by many factors, which is extensively discussed in Chapter 5 . However, this thesis mainly focusses on bank strength as a result of the bank texture (siltplus-clay fraction), organic content and consolidation. This does not mean that other factors such as vegetation are not important for the river morphodynamics. In fact, vegetation that fixes the bank may also increase bank strength as I discuss in Chapter 5, but this relation between vegetation and bank strength is complex and still difficult to quantify (Hickin, 1984; Gibling and Davies, 2012; Gurnell, 2014; Corenblit et al., 2015; Van Oorschot et al., 2016).

The channel pattern can differ between channel reaches, because of spatial differences in bank strength at a catchment scale. For example, the Milk River changes from a meandering river to a braided river further downstream, and finally becomes a straight, laterally stable river at its most downstream end (Figure 1.2b). This variation is predominantly due to a longitudinally variable bank strength that differs significantly between the channel reaches (Simpson and Smith, 2001; Kleinhans and Van den Berg, 2011). The average silt-plus-clay fraction decreases from $65 \%$ in the meandering reach to $18 \%$ in the braided reach, and is $85 \%$ in the laterally stable reach (Simpson and Smith, 2001) (Figures 6.3 and 6.4, river 5).

The degree of lateral activity between reaches with a similar channel pattern can also differ, because of spatial differences in bank strength at a catchment scale (Hooke, 1980). In the Overijsselse Vecht, the highest lateral migration rates were found at the Junnerkoeland bend (Chapter 4) (Quik and Wallinga, 2018), because here the banks consisted of relatively easily erodible, aeolian sands compared to more erosion-resistant, cohesive banks in other river reaches (Wolfert and Maas, 2007). Eekhout et al. (2013) showed that the degree of meandering longitudinally differed between channel reaches of the GeldersNierskanaal, because seepage locally weakened the banks resulting in the most active meanders compared to sections without seepage. Hudson and Kesel (2000) also showed that the Mississippi River was laterally most active where few clay plugs are present.

Bank strength can also differ within a reach, affecting the morphodynamics and channel pattern. This difference was extensively demonstrated in Chapter 3 , in which the tortuous channel pattern (river type 3) formed as a result of the heterogeneous floodplain, and lateral migration rates strongly differed for each river bend. This finding was in line with outcomes of numerical modelling studies (Güneralp and Rhoads, 2011; Motta et al., 2011; Bogoni et al., 2017). In contrast, homogeneous floodplains host either channels with relatively uniform bend migration rates (river type 1) (Hickin, 1974; Hickin and 
Nanson, 1975; Sylvester et al., 2019), or host channels that are virtually laterally stable (river type 2) (Woodyer et al., 1979; Kleinhans et al., 2009).

Additionally, the erosion-resistance of the valley side is an important factor affecting the morphodynamics. For example, bed-rock rivers have a relatively erosion-resistant valley side, hence the river is laterally constrained within the valley (Turowski et al., 2008; Finnegan and Dietrich, 2011). In alluvial rivers, this constraining could lead to sharp right-angled bends that laterally migrate downstream when valleys are relatively narrow compared to the river size (Page and Nanson, 1982; Nicoll and Hickin, 2010), or could initiate self-constraining with the first sharp bends forming once the river hits the valley side (river type 3, Figures 3.12, 6.1c and 6.2).

Rivers that have a relatively easily erodible valley side show the opposite behaviour. Here the river does not constrain within the valley, but tends to escape out of the valley. In fact, the valley sides of the obliquely aggrading peatland rivers shift outward with time partly because of erosion of the valley side (Chapter 2, Figures 6.1d and 6.2). Also the valley side of the Overijsselse Vecht was locally easily erodible, especially where the valley side consisted of unconsolidated aeolian deposits (Chapter 4, Figure 6.2). Several meanders formed outside the original channel belt (Quik and Wallinga, 2018). Numerical models confirmed that rivers may develop extremely large meanders and migrate out of the valley when the valley side is relatively easily erodible (Sun et al., 1996; Bogoni et al., 2017).

In this thesis I showed that bank strength can also change with time (Chapter 3). Meandering rivers may be subjected to relatively rapid overloading with cohesive sediments (e.g. due to land use change), and change into a laterally stable river. Peakall et al. (2007) described this cessation of channel migration as ossification of the channel pattern, resulting from a fast increase of cohesive deposits. In self-constraining rivers (river type 3), the bank strength tends to increase with time, because rivers have too limited stream power to remove relatively erosion-resistant depositional units, while they continuously form easily erodible and relatively erosion-resistant depositional units (Figures 3.12, 3.13 and 6.1c). As sharp bends form in these rivers, conditions are created in which erosion-resistant depositional units, such as clay plugs and counterpoint deposits, are predominantly formed (Chapter 3). In both self-constraining and obliquely aggrading rivers (river types 3 and 4), peat growth within the valley results in an increasingly erosion-resistant valley fill (Chapters 2 and 3, Figure 6.1c,d). Consolidation further enhances the bank strength of cohesive and organic deposits. Figures 3.12 and 3.13 illustrate the increasing bank strength due to the self-constraining process, and shows that the required energy needed for a channel pattern change increases. 


\subsubsection{Bar regime}

Figure 5.4 and Table 6.1 show that channel width-depth ratios lower than ca. 10 are common in laterally stable rivers, because the width-depth ratio strongly depends on bank strength (Ferguson, 1987). Such low width-depth ratios are for example found in lowenergy rivers in peatlands that have very steep banks because of the high bank strength, resulting in relatively deep and narrow channels (Table 6.1) (Nanson, 2010). Often these low width-depth ratios of low-energy rivers are attributed to human influence, for example the influence of water mills which would cause the river to incise (Walter and Merritts, 2008; Brown et al., 2018; Maaß and Schüttrumpf, 2019). However, based on the studied cases here, I suggest that most low-energy rivers had a low width-depth ratio already before human influence, as derived from lithogenetic cross-sections and GPR profiles across palaeochannels (Chapter 2 to 4 ).

Rivers with such a low width-depth ratio have an overdamped regime (Struiksma et al., 1985; Kleinhans and Van den Berg, 2011), meaning that when a bar forms in response to a local perturbation, the bar disappears within a short distance of the perturbation (Struiksma et al., 1985) (Chapters 4 and 5). A perturbation in one bend does not necessarily lead to a perturbation in the consecutive downstream bend, therefore rivers with an overdamped regime (river types 2 to 4) strongly differ from rivers with an underdamped regime (river type 1, Chapters 4 and 5) (Struiksma et al., 1985; Crosato and Mosselman, 2009). An overdamped regime naturally results from a low width-depth ratio, and enhances the lateral stability of the river in addition to the bank strength that leads to the low width-depth ratio. Despite the overdamped regime, these channels still show traces of lateral migration as could be derived from OSL datings taken from the inner bank at both the Dommel and the laterally stable phase of the Overijsselse Vecht river (Chapters 3 and 4). Also the Drentsche Aa shows very limited lateral migration due to the oblique aggradation (Chapter 2). As I discussed in the previous Sections 6.4.1 and 6.4.2, lateral migration of river types 2 to 4 is largely caused by flow impinging on the weakest banks, or by incidental bank collapse (Kleinhans et al., 2009).

\subsubsection{Concluding remark}

In this Section 6.4, I described that spatial and temporal changes in the balance between stream power and bank strength have relatively large consequences on the channel pattern formation of low-energy rivers, because these river types are on the margin of the river continuum in terms of stream power sufficient for bank erosion. Therefore, local conditions of bank strength and stream power strongly determine the rate and direction of bank erosion for each river bend, independent of the conditions in upstream or downstream bends due to an overdamped regime (river types 2 to 4) (Struiksma et al., 1985; Seminara, 2006; Crosato and Mosselman, 2009). Hence, tortuous patterns can 
develop in heterogeneous floodplains, and patterns with rectangular bends and straight reaches in peat-filled valleys.

\subsection{Extrapolation of results outside the studied scales}

\subsubsection{Temporal scale}

In this section, I discuss the extrapolation of results outside the studied scales in this thesis. In all case studies, high-resolution subsurface information was gathered by coring at small distance intervals (down to $5 \mathrm{~m}$ in Ch. 2), using high-resolution GPR and geochronological methods (Chapters 2 to 4 ). Hitherto, detailed characterization of the lateral migration history by using OSL (Chapters 3 and 4) has hardly been done by others (Rodnight et al., 2005; Quik and Wallinga, 2018), but it proofs to be a very valuable method to study historical river morphodynamics and adds to existing applications of OSL in fluvial settings (Wallinga, 2002; Wallinga et al., 2010).

These palaeogeographic methods mostly cover a timescale of ca. $10^{2}$ to $10^{4}$ years (Figures 1.3 and 6.5). As described in Sect. 1.4.1, I used these methods because the human lifetime is often too short to observe the geomorphological processes that underlie channel pattern formation of low-energy rivers, and low-energy rivers are relatively laterally stable on a typical observational timescale (Eekhout, 2014). This timescale of palaeogeographic methods is outside the timescale of interest of river managers, which commonly ranges from days to decades, i.e. the timescale of river maintenance, the morphodynamics (e.g. bed morphology changes, bank collapse or erosional effects of large flood events) and ecological state (Figure 6.5). However, to create self-sustaining rivers in river restoration projects (i.e. rivers in which river management is limited), the geomorphological rules should be obeyed (Brierley and Fryirs, 2009; Hulscher et al., 2014; Pedersen et al., 2014; Makaske and Maas, 2015), which can be derived from longer timescales. 


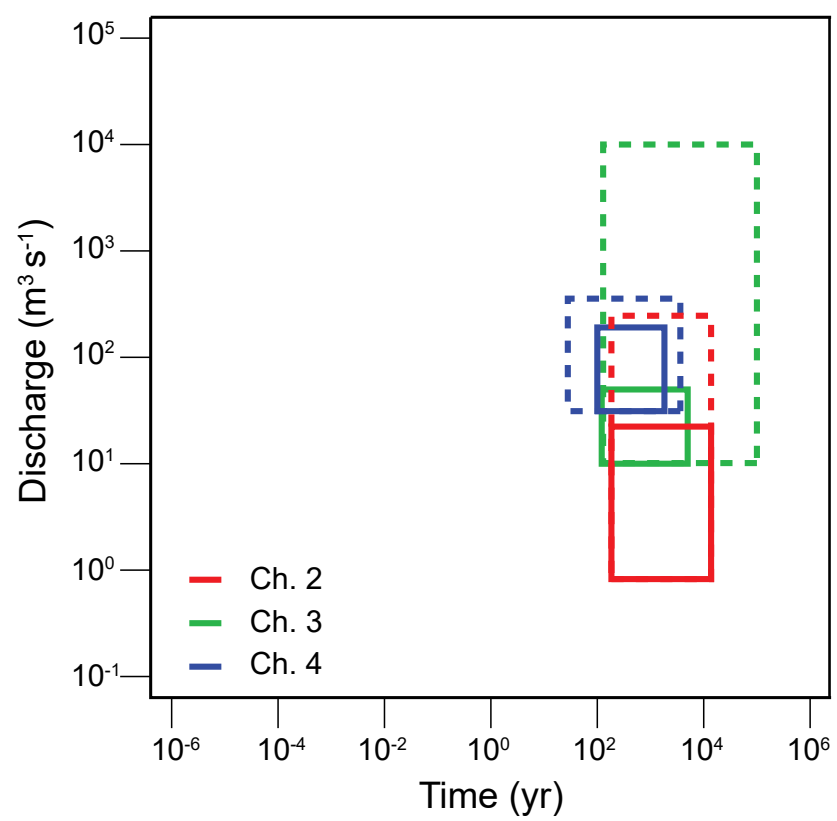

Figure 6.5 Timescale and spatial scale, expressed as the river discharge, on which rivers were studied in this thesis. Lines indicate the studied cases of each chapter, the dashed lines indicates the scales of the discussion in each chapter.

This research did also not focus on the morphological evolution of low-energy rivers on even longer timescales (Figure 6.5). As discussed in Section 3.5, river stream power is generally high during glacials, and low during interglacials in many temperate regions. Very limited fluvial deposits have been preserved from the pre-last interglacial (Eemian), because rivers had high lateral activity, wide channel belts and high sediment transport during the consecutive glacial period (Weichselian) removing most older fluvial deposits (Figure 6.2) (Vandenberghe, 1995, 2001; Busschers et al., 2005; Peeters et al., 2015; Peeters et al., 2016). This research did not include glacial-interglacial timescales ( $10^{5}$ to $10^{6}$ years, Figure 6.5), however, I expect that similar patterns of low-energy rivers existed during the Holocene, the Eemian, older interglacials, and before the Quaternary.

Even longer timescales ( $10^{6}$ to $10^{8}$ years) should be studied to improve the estimates of hydrocarbon, geothermal and groundwater reservoir capacity of fluvial deposits of low-energy rivers in the rock record (e.g. Smith et al., 2009). Reservoir capacity may be very limited in ancient deposits of low-energy rivers where relatively high amounts of fine-grained and organic deposits with a low hydraulic conductivity (river types 2 to 4) are present. These deposits are often poorly mapped due to limited recognisability and the use of relatively simple alluvial facies models that are mostly based on river type 1, as also argued by Makaske and Weerts (2005) and Smith et al. (2009). Smith 
et al. (2009) suggested that the presence of counterpoint deposits in the McMurray Formation may explain why bitumen production rates in some wells do not reach the expected production rate. Improved alluvial facies models of low-energy rivers will facilitate better mapping of the subsurface, which will result in improved predictions on reservoir capacity and connectivity.

\subsubsection{Discharge scale}

In this study, the term low-energy rivers has been restricted to rivers with a bankfull discharge $<200 \mathrm{~m}^{3} \mathrm{~s}^{-1}$ (Sect. 1.2.1), because re-meandering mostly applies to these small rivers, while river management of larger rivers is more concerned with flood safety, navigation, hydropower and water supply (Hulscher et al., 2014; Best, 2019). Small rivers are more often low-energetic $\left(<10 \mathrm{~W} \mathrm{~m}^{-2}\right)$ than large rivers, because they have a lower bankfull discharge. However, I elaborated upon low-energy rivers with bankfull discharges $>200 \mathrm{~m}^{3} \mathrm{~s}^{-1}$ in all chapters (Figure 6.5), such as the Purus River $\left(1.7^{*} 10^{4}\right.$ $\mathrm{m}^{3} \mathrm{~s}^{-1}$ ), which also self-constrained its channel pattern (Figure 3.13). Although many similarities exist between small and large low-energy rivers, e.g. low gradient, high suspended load, comparable depositional units, flow separation, similar channel patterns (e.g. Kleinhans, 2010; Smith et al., 2011; Kleinhans et al., in review), caution is needed when comparing these rivers, because there are large differences in biogeomorphological processes (Viles et al., 2008; Camporeale and Ridolfi, 2010; Gurnell, 2014; Corenblit et al., 2015).

Vegetation and animals do not scale with river size. Hence, tree-fall or perturbations by animals may have larger effect on small rivers than on large rivers (e.g. Beschta and Ripple, 2012; Giriat et al., 2016; Wohl, 2017). For example, beavers may build dams crossing the entire river width in small rivers (up to $40 \mathrm{~m}$ ), where they cause a backwater effect and locally affect the river morphology, whereas they hardly affect the hydrology and morphology of larger rivers (Gurnell, 1998; Giriat et al., 2016). Similarly, log jams may cause severe flooding and erosion in small rivers, but hardy occur in large rivers (Moulin et al., 2011). Trampling and grazing of animals (Trimble and Mendel, 1995; Beschta and Ripple, 2006; Beschta and Ripple, 2012) have been shown to widen small river channels, but hardly affect large rivers. Rooting of vegetation may enhance bank stability in small rivers, whereas this effect is limited in large rivers because large river channels are deeper, hence roots penetrate a smaller proportion of the total bank thickness (Millar, 2000; Corenblit et al., 2007; Gurnell, 2014). 


\subsubsection{Grain size scale}

The river types defined in Sect. 6.2 are mostly based on the case studies in The Netherlands, given that the main focus of this research is on these areas that are dominated by coversand. Therefore only sand-bed rivers were included in the river typology, while gravel-bed rivers are missing. However, I expect that gravel-bed rivers also fit the river typology as defined in Sect. 6.2, although their specific stream power is usually higher than the $10 \mathrm{~W} \mathrm{~m}^{-2}$ that defines low-energy rivers (Sect. 1.2.1, Figure 5.2d) (Nanson and Croke, 1992). Gravel-bed rivers are meandering (river type 1) when they have sufficient stream power to mobilize their bed material, according to the channel pattern predictor (Figures 5.7 and 5.8). In Sect. 3.5, I argue that self-constraining is unlikely in gravel-bed rivers, because they require high river energy to mobilize the river bed material. At such energy they are usually able to erode banks irrespective of bank strength (Ch. 5), which is corroborated by the position of the discriminators in the channel pattern predictor (Figures 5.6 to 5.8). Consequently, gravel-bed rivers are rarely laterally stable, which can also be seen in the dataset by Kleinhans and Van den Berg (2011) (Figure 5.4d). Though, Warburton et al. (2002) described a gravel-bed river that became laterally stable (river type 2 ) due to a low gradient and cohesive river banks, agreeing with the river typology in Sect. 6.2.

Many rivers in peatlands commonly have clastic bed material (Chapter 2) (e.g. Gradziński et al., 2003; Nanson, 2009). However, these rivers cannot be included in the channel pattern predictor, because the axis that represents bank strength only includes the silt-plus-clay fraction (see Sect. 5.4). It would be valuable to also include peat banks on this axis, which may be done by running experiments to find at which silt-plus-clay fraction the shear stress needed to erode a cohesive bank is equal to erode a peat bank.

\subsection{Implications}

\subsubsection{River restoration: river management}

Rivers should not be restored to a certain historic state of reference, because historic river conditions may not always be valid anymore (Dufour and Piégay, 2009). With the palaeogeographic knowledge gained in this study, more emphasis can be put on restoring the natural processes of low-energy rivers in a scientifically sound way. The typology of low-energy rivers (Sect. 6.2) and the newly developed channel pattern predictor (Ch. 5) help to determine whether river reaches may have the potential to meander or are likely to be laterally stable. 
Single-thread, single-channel rivers are more than a sinuous line in the landscape, although their floodplains have been disconnected from the river during the channelized phase over the past centuries (Sedell et al., 1990; Brierley et al., 2006). Natural rivers regularly flood their floodplain, may erode their floodplain when sufficient stream power is available and form new depositional units. Nevertheless, river restoration often still involves redesigning the river channel, while the floodplain morphology and composition are ignored (Kondolf, 2006; Walter and Merritts, 2008; Brierley and Fryirs, 2009). In this research I show that the sediment composition of the floodplain is key to understand the channel pattern and lateral river dynamics, and should be considered to predict the future channel pattern and lateral activity to prevent undesirable erosion, or provoke bank erosion when desired (Florsheim et al., 2008). Basic information about the subsurface may be derived from geological maps, DEMs or soil maps if available at the required scale. More detailed subsurface information can be derived by coring or using geophysical methods such as GPR.

River management requires an understanding of the entire catchment (Chapter 4), and should take into account future changes in climate and land use that affect the discharge regime. In The Netherlands it is expected that peak discharges will increase as a result of climate change and urbanization (Booth et al., 2016). Land use change, particularly urbanization, will have a significant effect on the flooding rates in catchments (Pfister et al., 2004). In temperate climatic zones, precipitation events will occur more frequently and will be more severe in the $21^{\text {st }}$ century (Lenderink and Van Meijgaard, 2008). Winters will be wetter with increased flooding rates, and summers will be drier in northwestern Europe (Quesada et al., 2012; Forzieri et al., 2016; Blöschl et al., 2017). These changes will result in laterally more active rivers when bank protection is removed in river restoration (Chapters 3 to 5), and are therefore important to take into account.

River managers should identify which river type they are restoring, based on a morphological and hydrological characterization of the river and its floodplain in the current and future setting. Here I shortly elaborate upon the specific aspects of river management for the different river types. Meandering rivers (river type 1) show the most lateral migration of all low-energy river types. This river type requires sufficient space for the river to meander, hence I recommend that river managers reserve a large part of the floodplain when they restore this river type. Soar and Thorne (2001) and Makaske and Maas (2015) suggested designing new stream channels based on calculations of the hydraulic and channel pattern geometry that fit the current stream power rather than copying these aspects from historical maps. Although the focus of this thesis was not on channel pattern evolution of restored rivers, I expect that this river type will naturally 
form its own river channel dimensions when it is able to freely erode its floodplain. Hence, the constructed geometry can be underfit relative to the imposed discharge.

Laterally stable (river type 2) and obliquely aggrading (river type 4) rivers do not laterally migrate, hence these river types require less space for the river channel to migrate. Though, caution is required because local, isolated lateral channel displacements in laterally stable rivers may occur, especially in the years after restoration (Eekhout et al., 2014; Eekhout et al., 2015). However, river managers should not intervene, because the river channel will form its natural dimensions when the constructed geometry is underfit, and will become laterally stable after several years (Eekhout et al., 2014; Eekhout et al., 2015). Caution is also required for regular flooding of the floodplain in both river types, hence space for flooding should be reserved within the floodplain. The channel pattern of these river types has changed little over the last thousands of years and has little relation to the hydrology of the system and limited changes thereof. Therefore, historical maps may provide excellent input to design the channel pattern of these river types, under the condition that river mangers first characterize the natural hydrological and morphological conditions. In these laterally stable rivers, I recommend that sharp bends are restored (see argumentation given in Sect. 6.7.2). When channels of obliquely aggrading rivers are placed along both valley sides, the process of oblique aggradation can also be restored if the natural peat growth is restored. Peat growth can be restored by increasing the buffer capacity of the catchment to ensure perennial flow in the river valley, and by stopping large groundwater extractions in the area.

Self-constraining rivers (river type 3) may locally laterally migrate, depending on the level of self-constraining. River managers should either map the floodplain to predict the future river channel pathway, or reserve a large part of the floodplain for the potential lateral migration of the river. When the heterogeneity of the floodplain sediment composition is known, the river can be placed in relatively cohesive sediments where there is no space for the river to further shift, and in unconsolidated sediments where river migration is desired and does not threaten infrastructure. Like for meandering rivers, I expect that the river will naturally form its own river channel dimensions when it is able to freely erode its floodplain. Hence, the constructed geometry can be underfit relative to the imposed discharge. Sharp bends may also naturally form where the river encounters erosion-resistant deposits following lateral migration.

In recent reviews, Notebaert and Verstraeten (2010) and Brown et al. (2018) stated that most rivers in Western and Central Europe were dispersed wetland systems without a clearly-defined channel during the Early and Middle Holocene. They argued that these rivers changed into rivers with a well-developed channel and floodplain during 
the Middle and Late Holocene. This is mostly based on case studies where an organic floodplain during the Early Holocene changed into a clastic floodplain during the Middle to Late Holocene. Only rivers with a larger catchment, e.g. the Rhine, were believed not to have been dispersed wetland systems (Broothaerts et al., 2014b). However, I did not find any evidence of dispersed wetland systems in the studied reaches in the Drentsche Aa and the Dommel River valley, because river channel deposits were found of which the dates cover the entire Holocene (Chapters 2 and 3). Moreover, the Drentsche Aa system shows that an organic floodplain does not exclude the presence of a distinct river channel, which is also known for other rivers in peat-filled valleys (e.g. Gradziński et al., 2003; Nanson, 2009). Similarly, others found evidence of Early-Holocene meandering river deposits for the low-energy rivers Geul (De Moor et al., 2008), Scheldt (Storme et al., 2018) and Roer (Kasse et al., 2016). Based on their findings, Storme et al. (2018) also questioned whether most low-energy rivers were dispersed wetland systems across Western and Central Europe.

It is unknown under which abiotic and biotic boundary conditions both systems (with or without channel) emerge in lowland valleys. This knowledge is vital to have river restoration succeed, because some recent river restoration projects involve restoring dispersed wetland systems rather than re-designing a river channel in lowlands. Such efforts especially require a better understanding of the biotic controls on river morphodynamics (see also Sect. 5.4), which is a field that is still relatively young (Gurnell, 2014).

\subsubsection{River restoration: ecology}

River restoration should not only focus on the river channel, but also incorporate the floodplain, because the floodplain forms one of the most species-rich environments (Straatsma et al., 2017; Van Iersel et al., 2018), functions as a buffer for pollutants (Burt, 1996) and dampens out peak discharges (Dessie et al., 2014). Large differences in the subsurface composition can be found in the floodplain of meandering and selfconstraining rivers (river types 1 and 3), and topographic differences due to the levees and scroll bars providing different habitats (Richards et al., 2002). Restoration of obliquely aggrading rivers (river type 4) should especially incorporate the floodplain, because permanent high water levels are needed to keep the peat intact, otherwise peat oxidation results in enrichment of nutrients and loss of ecological value (Aldous et al., 2005). Self-constraining and obliquely aggrading river valleys can also be used as sinks of carbon. The highest site turnover followed by renewed floodplain succession occurs in meandering rivers, and partly in self-constraining rivers, where new deposits are colonized by pioneer species, while mature species exist on the older parts of the floodplain (Gurnell et al., 2006; Morris and Stanford, 2011; Van Oorschot et al., 2016). 
Riparian vegetation is important to include in the floodplain design, because vegetation affects the bank stability, and its shading provides cool places for aquatic and terrestrial species (Gurnell et al., 2012; Gurnell, 2014; Gurnell et al., 2015).

Within the channel, running water is considered as the most important element to reach the highest river biodiversity (Kail et al., 2015; Poppe et al., 2015). To sustain perennial flow, it is important to restore rivers applying a catchment-scale approach, restoring the buffer capacity of the catchment (Kaandorp et al., 2018; Kaandorp et al., 2019), especially in rivers that heavily rely on groundwater such as the studied low-energy rivers in this research. Some rivers have a relatively high discharge variation within a year, such as the studied meandering Overijsselse Vecht (Ch. 3), while others have a relatively constant discharge, such as the Dommel River (Ch. 4, Table 1.1). I expect that substrate variation is largest in self-constraining rivers seen the heterogeneous sediment transport (Ch. 3). These variations in discharge and substrate are positive for the ecological status, although high peak discharges can incidentally destroy habitats (Cobb et al., 1992; Verdonschot and Van den Hoorn, 2010). Gradual sloping banks are most common in meandering rivers, and attract many species due to the different dynamics of flow along the gradient. Steep banks are present in all low-energy river types, and attract different types of birds, such as swallows (Armitage et al., 2001; Wohl and Merritts, 2007; Silver and Griffin, 2009).

As discussed in Section 6.2, sharp bends are the rule rather than the exception in most low-energy rivers (river types 2 to 4) (Kleinhans et al., in review). Flow recirculation within sharp bends provides zones of reduced flow conditions, where fine sediments settle and distinct ecological niches form (Trinci et al., 2017; Kleinhans et al., in review). In their review, Trinci et al. (2017) showed that such zones are essential for fish and aquatic invertebrates to shelter, forage and spawn. These reduced-flow conditions are now often created by adding woody debris to the river as part of the river restoration (Tullos and Walter, 2015; dos Reis Oliveira et al., 2019). Nevertheless, smoothly curved meanders are usually designed in river restoration projects (Kondolf, 2006), ignoring the ecological potential of these sharp bends. This might explain that large and costly river restoration measures (e.g. re-meandering) do not result in higher habitat diversity than small measures (e.g. instream measures such as placement of woody debris) (Hering et al., 2015; Poppe et al., 2015), and that many river restoration projects fail to improve the ecological conditions (Pedersen et al., 2014; Verdonschot et al., 2015). It would be a missed opportunity when rivers are predicted to classify as river type 2 to 4 (Figure 6.1), not to restore their typical channel pattern with sharp bends, which provides vital habitats. 


\subsection{Conclusions}

In this thesis, I identified the most important controls on the channel pattern formation of low-energy rivers. The major conclusions of this research are pointed out below.

- Low-energy rivers can be characterised in four different types, of which the latter two are newly defined in this thesis: 1) meandering rivers, 2) laterally stable rivers, 3) self-constraining rivers, and 4) obliquely aggrading rivers. These river types are characterised by a distinct channel pattern, floodplain morphology and floodplain sediment composition (Figure 6.1, Table 6.1).

- The channel pattern formation of rivers is predominantly determined by the balance between stream power and bank strength. The composition of the bank is key to the lateral activity of low-energy rivers, because these rivers are on the margin of the river continuum in terms of stream power sufficient for bank erosion. Spatial erodibility differences of river banks are the main causes for the distinct channel patterns of self-constraining and obliquely aggrading rivers.

- Local conditions of bank strength and stream power determine the rate of bank erosion and direction of channel shifts for each river bend in river types 2 to 4. These local conditions are independent of the conditions at upstream or downstream bends due to an overdamped regime, in contrast to meandering rivers (river type 1) which have an underdamped regime.

- The channel pattern of laterally stable rivers (river type 2) is straight to irregular sinuous with occasionally sharp bends, which predominantly results from pattern inheritance and local perturbations. The channel pattern is completely laterally stable, despite a few local lateral channel displacements of sharp river bends. This river type has insufficient stream power for systematic lateral migration (Ch. 4), contrasting meandering rivers (river type 1). Meandering rivers have sufficient stream power to erode the depositional elements within the floodplain, leading to a classical meandering pattern with smooth bends.

- Self-constraining rivers (river type 3) result from spatial erodibility differences of the floodplain (Ch. 3). This floodplain heterogeneity is explained by the selfconstraining process of the low-energy river. Self-constraining occurs when lowenergy rivers predominantly erode the easily erodible, non-cohesive depositional units, while they continuously form both easily erodible and relatively erosion- 
resistant deposits. With time, the proportion of erosion-resistant deposits increases, leading to a constrained, tortuous river pattern.

- Obliquely aggrading rivers (river type 4) result from erodibility differences between the valley fill and valley side in an aggrading setting of a peat-filled valley (Ch. 2). The river develops a typical channel pattern with rectangular bends and relatively straight reaches that either follow the valley sides or cross the valley. This channel pattern results from a combination of floodplain widening as the valley fills, and river reaches aggrading obliquely along opposed valley sides.

- Channel patterns and changes of channel pattern can be predicted using the newly developed channel pattern predictor (Chapter 5), which includes river types 1 to 3. This channel pattern predictor uses parameters independent of actual channel pattern: potential specific stream power, median bed grain size and average siltplus-clay fraction of the banks. The latter is a newly introduced parameter, which is a proxy for bank strength. The addition of bank strength is an important step forward in the development of such predictors, because the success rate of the channel pattern prediction improved compared to existing predictors.

- Knowledge of the floodplain sediment composition is the key to successful restoration of low-energy rivers, because it largely determines future channel pattern and lateral activity.

\subsection{Future research}

In the research project RiverCare, the main focus was on the ecological, morphological, hydrological and sociological effects of measures in the larger rivers Rhine and Meuse. These rivers have important functions for navigation and flood safety, hence restoration potential of these river systems is often limited because these functions may not be negatively impacted by nature restoration. However, the RiverCare project showed that there is a lot of potential for nature-based solutions in the riverine landscape (Hulscher et al., 2014). For example, Collas et al. (2018) found that ecological conditions recovered fast due to longitudinal training dams; Van Denderen et al. (2018) showed that side-channels can be reconstructed, which enhances the flood safety and ecological state of the river; Koopman et al. (2018) and Bout et al. (2019) showed that there is much potential for biomass production in riverine landscapes; Straatsma et al. (2017) showed that biodiversity increased significantly as a result of river restoration measures that combine flood risk interventions with enhancement of biodiversity; Verbrugge and 
Van den Born (2018) showed that the interventions were positively perceived by the inhabitants.

A similar multi-disciplinary approach is needed to experiment with and study the effect of nature-based solutions in small low-energy river systems. Because navigation and flood safety are of less importance in these river systems, studies on these smaller low-energy rivers may provide valuable insights for larger rivers, because experiments can more easily be done in a relatively safe environment. A multi-disciplinary approach may enhance the insights on the morphological, ecological and hydrological effects of applying nature-based solutions to restore the natural channel pattern of low-energy rivers.

In Chapter 5 and Sect. 6.2 the different types of low-energy rivers were described. We find that three out of four river types have a channel pattern that consists of sharp bends. However, clear differences can be seen in channel pattern between these types, which I distinguished mostly qualitatively in this thesis. Laterally stable rivers have a relatively irregular sinuous pattern with occasionally sharp bends, self-constraining rivers have a tortuous pattern in which sharp bends have variable size and are skewed in all different directions, and obliquely aggrading rivers have a rectangular pattern with sharp bends and straight reaches (Figure 6.1). A better quantitative characterization of channel pattern is needed to distinguish these river types. Vermeulen et al. (2016) developed a wavelet analysis to quantitatively distinguish meandering patterns from satellite imagery, for example by comparing the skewness of river bends between rivers. Such a method can be applied to quantitatively distinguish the characteristics of the different low-energy river types to improve their classification.

In this thesis I mostly focussed on the boundary between laterally stable and laterally active river systems, in which meandering rivers with scroll bars are on the upper margin of the continuum of low-energy rivers. Yet, the lower margin of the continuum should be further explored, given its relevance for restoration projects. As mentioned in Sect. 6.6.1, natural river systems during the Early and Middle Holocene may have been dispersed wetland systems, lacking a clearly defined channel (Notebaert and Verstraeten, 2010; Brown et al., 2018). Although this research did not show evidence of systems without a river channel, it may be expected that sufficiently low stream power provides the conditions for these systems to emerge. I expect that the discriminator is similar to the threshold for motion of sediments, because sufficient stream power is needed to move sediment to form a river channel (Figure 6.6). However, dispersed wetland systems are usually dominated by peat, therefore it is unknown whether Figure 6.6 can be applied. The first step would be to include river systems in peatlands into the channel pattern predictor. This could be done by incorporating the organic fraction on the third 
axis together with the silt-plus-clay fraction. The next step is then to find the boundary between the systems with and without a channel.

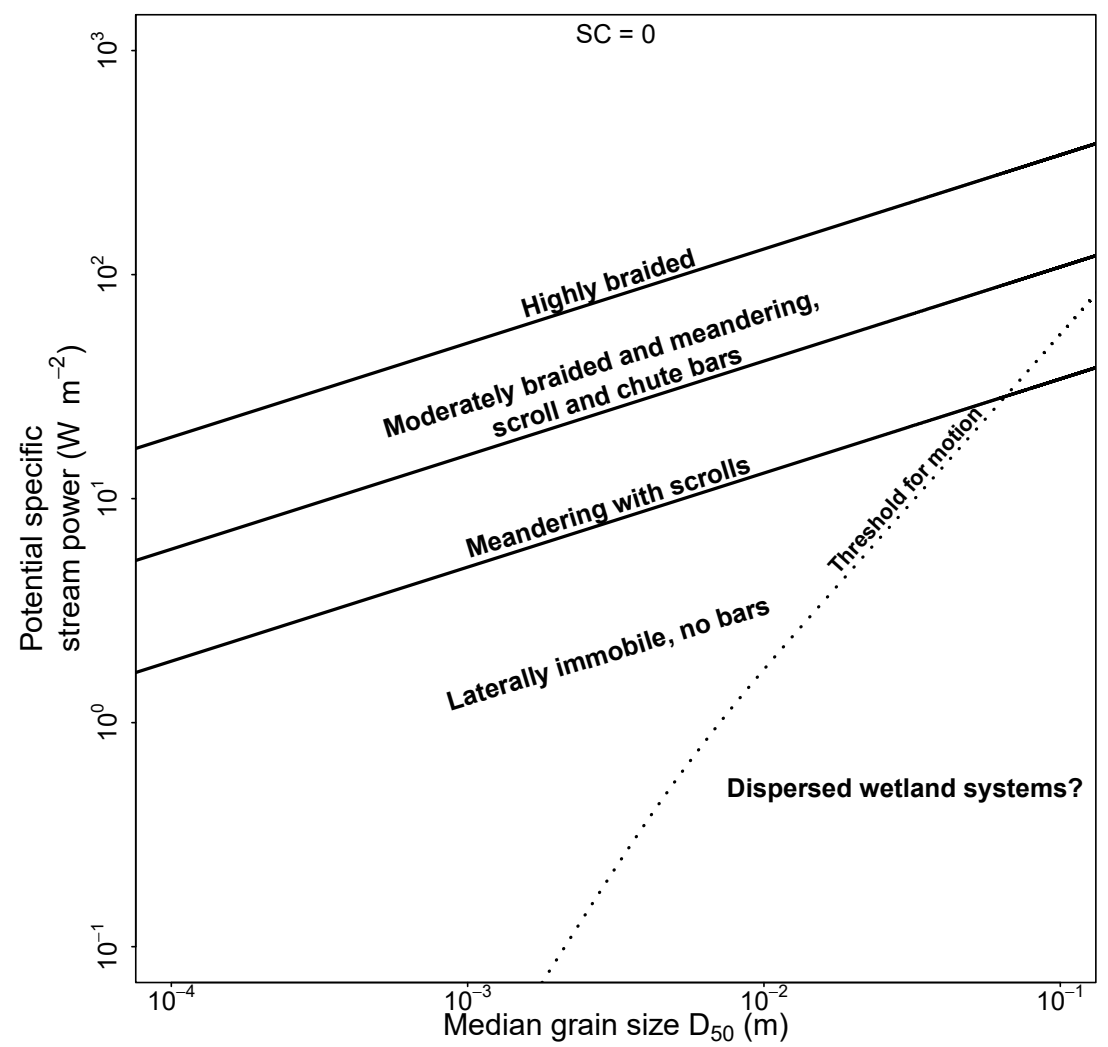

Figure 6.6 Channel pattern predictor showing the threshold for motion as a potential discriminator between systems with and without a channel.

The present study shows that low-energy rivers predominantly have an overdamped regime, in which flow separation is present within the sharp bends. However, actual flow patterns were not measured in this research. Hence, most of these findings were derived from bar regime, which could be reconstructed from the fluvial record by reconstructing the width-depth ratio (Ch. 5), and by comparison to other research that linked the observed sharp bends and counterpoint bars to flow separation (e.g. Smith et al., 2009; Blanckaert et al., 2013; Geertsema et al., submitted). This research also confirmed that sharp bends develop where the channel meets the relatively erosion-resistant floodplain. However, it is unknown how the flow and channel pattern interact; how does a sharp bend develop, how does the flow separation develop during this bend development and how does the flow separation enhance the development of the sharp bend during 


\section{Chapter 6}

this process (questions also raised by Kleinhans et al., in review)? Given the dominant presence of sharp bends and flow separation in low-energy rivers and the potential for ecological restoration, these rivers would be ideal to study these phenomena by field studies. Additionally, flume experiments should be done to control the bend curvature and morphology (Kleinhans et al., in review). 



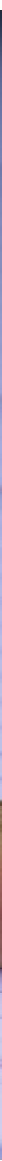

Photo by Niels Kijm 


\section{Summary}

\section{Ahead of the curve - Channel pattern formation of low-energy rivers}

Many rivers have been channelized and straightened in large parts of the world in the past centuries. These measures were taken to drain the land, to produce hydropower, to enhance navigation and to reduce bank erosion. However, in the last decades, realization has grown that channelization has large negative consequences: it results in loss of ecological niches, lowering of groundwater tables and high discharge peaks that may lead to flooding. Therefore, rivers are currently being restored, especially in Europe and North-America. One of the most used restoration measures in small, low-energy rivers is to re-meander the river channel pattern (Figure 1.1), often by mimicking the sinuous pattern from before channelization based on historical maps, to restore the "natural" state of the river. However, the historic river conditions that the design of re-meandering projects is often based on may nowadays not be valid anymore and may be impossible to return to.

In this research, the focus is on small, low-energy rivers to which the restoration measures of re-meandering mostly applies; rivers with a specific stream power $<10 \mathrm{~W} \mathrm{~m}^{-2}$ and a bankfull discharge $<200 \mathrm{~m}^{3} \mathrm{~s}^{-1}$. More specific, the focus is on small, low-energy rivers that are single-channel, single-thread, alluvial and located in a valley setting. Such rivers are abundantly present on the northwestern European lowland plain. Rivers with organic floodplains are also considered as alluvial rivers in this research.

Although sinuous river patterns are created in restoration projects, it remains largely unknown how sinuous patterns of low-energy rivers naturally form and develop with time. Many low-energy rivers do not have sufficient energy to erode their banks, and do not show lateral migration. Nevertheless, much space is often reserved in river restoration projects for the low-energy rivers to freely meander. Additionally, it was found that the ecological state of rivers does not improve when the geomorphological conditions are ignored in re-meandering projects. The realization has grown that geomorphological studies are needed to predict and give insight into the future channel pattern and dynamics, and align the ecological state with the geomorphological conditions.

In this doctoral thesis, I aim to understand and predict the channel pattern formation of low-energy rivers to inform river managers in river restoration projects. The objectives of this study are: 1) to define a typology of low-energy rivers, accounting for their channel pattern, floodplain morphology and floodplain sediment composition, 2) to reconstruct the channel pattern formation of different types of low-energy rivers and identify the key forming factors of channel pattern, 3) to develop a channel pattern predictor for 
different types of low-energy rivers, based on parameters independent of actual channel pattern.

An overview of the thesis structure is given in Figure 1.4. The main focus of this thesis is on long-term river morphological development $\left(10^{2}\right.$ to $10^{3}$ years), because I expect that channel pattern changes occur relatively slowly. I studied the channel pattern formation of three case study rivers in The Netherlands during the Holocene. These case study rivers were selected predominantly based on their different valley fills, because the floodplain sediment composition may have a large effect on the channel pattern formation. These rivers also vary in size and as to the composition of their valley sides (Table 1.1). I selected low-energy rivers in predominantly peaty (Ch. 2), heterogeneous (Ch. 3) and sandy (Ch. 4) valley fills. Their channel pattern was sufficiently wellpreserved to reconstruct its formation of each of these rivers from before regulation and/ or channelization. I used the insights from the case studies to develop a channel pattern prediction tool for low-energy rivers (Ch. 5).

The first studied river (Ch. 2) is the Drentsche Aa in the northern part of The Netherlands (Figure 2.1), which is located in a peat-filled valley with sandy valley sides. The peat reaches thicknesses up to $8 \mathrm{~m}$, and started growing in the end of the Late Glacial. Previous studies showed that this river is laterally immobile, hence it is unknown how its highly sinuous pattern formed. I performed a detailed palaeogeographic reconstruction using coring, ground-penetrating radar and geochronological data from different valley cross-sectional research sites. Based on this reconstruction, I developed a conceptual model on how the channel pattern formed since the start of the peat growth. The present pattern is a result of oblique aggradation, which is a combination of vertical aggradation and lateral displacement (Figure 2.9). During peat growth, the river tends to adhere to the sandy valley side, due to its low erosion-resistance compared to the peaty valleyfill. The floodplain of the river widens as a result of erosion of the valley side, and peat growth in the $\mathrm{V}$-shaped valley. Adherence of river reaches to the valley sides, in combination with floodplain widening, results in a river that is stretched out resulting in increased sinuosity. This stretching of the river results in a very distinctive pattern, with rectangular bends and relatively straight reaches that either follow the valley sides, or cross the valley (Figure 2.9). This river pattern is more or less laterally stable, because oblique aggradation is a relatively slow process, and fundamentally differs from the classic meandering pattern. The typical pattern was also observed for other peatland rivers around the world from satellite imagery (Figure 2.10).

The second studied river (Ch. 3) is the Dommel River in the southern part of The Netherlands (Figure 3.2), which is located in a valley with a heterogeneous fill and 
relatively loamy sides. Before artificial straightening, this river had a very complex pattern consisting of unusually sharp bends with variable size and abrupt, irregular changes in channel direction (i.e. a tortuous pattern), lacking the typical smoothness of ideal meander curves (Figure 3.1a). Based on palaeogeographic reconstructions, I developed a conceptual model on how this channel pattern formed during the Holocene (Figure 3.12). The river is autogenically constrained within its self-formed heterogeneous floodplain, and develops a tortuous pattern with very limited channel mobility due to insufficient flow strength to erode its cohesive banks, while the river can erode the non-cohesive, sandy banks. This self-constraining tendency was corroborated by an analysis of 47 rivers from around the world, which showed that erosion-resistant floodplain deposits are preserved in the river banks when the river energy is below a critical threshold (Figure 3.13). Self-constraining is initiated once river energy decreases, e.g. due to a reduction of peak discharges with changes in land use or climate. Because of better preservation of cohesive deposits compared to non-cohesive deposits, the required energy needed to break out of the self-constraining tendency increases with time. Selfconstraining thereby enhances resistance against bank erosion, but the river is able to break out of the self-constraining trend if river energy increases to such an extent that the threshold for erosion of cohesive bank material is crossed.

The third studied river (Ch. 4) is the Overijsselse Vecht in the eastern part of The Netherlands (Figure 4.1), which is located in a valley with a relatively sandy fill and sandy sides. This river was completely channelized after 1914 AD, but well-preserved palaeochannels and scroll-bars are still located in the valley. Based on geochronological data and a palaeogeographic reconstruction, I concluded that the river changed from a laterally stable into a meandering river ca. 1400 to $1500 \mathrm{AD}$. I reconstructed the bankfull discharge as a function of time from these fluvial deposits, and showed that a significant increase of the bankfull discharge was the main cause of the channel pattern change (Figures 4.9 and 4.11). This increase of bankfull discharge was likely due to the combined influence of a climatic fluctuation (the Little Ice Age, $14^{\text {th }}$ to $19^{\text {th }}$ century), and peat reclamation and exploitation in the catchment.

Based on the case studies, low-energy rivers can be characterised in four different types by their distinct channel pattern, floodplain morphology and floodplain sediment composition (Figure 6.1, Table 6.1), of which the latter two are newly defined in this thesis: 1) meandering rivers have relatively smooth bends, laterally migrate and develop a scrolled floodplain. These rivers have sufficient stream power to erode the floodplain. 2) Laterally stable rivers have an irregular sinuous pattern with straight reaches and occasionally sharp bends. These rivers do not laterally migrate because stream power is insufficient to erode the floodplain. The channel pattern results from inheritance of 
former channel pattern and perturbations (e.g. tree fall). 3) Self-constraining rivers have a tortuous channel pattern and show local lateral migration with scroll-bar development. These rivers have sufficient stream power to erode the non-cohesive floodplain deposits, but insufficient to erode the cohesive floodplain deposits. 4) Obliquely aggrading rivers have relatively rectangular bends with straight reaches in between. These rivers have sufficient stream power to erode the sandy valley sides, but insufficient to erode the peaty valley fill.

Based on the river typology, it can be derived that the bank strength is a key forming factor of the channel pattern of low-energy rivers. Because these rivers are on the margin of the river continuum in terms of stream power sufficient for bank erosion (Ch. 6), relative small differences in the balance between stream power and bank strength determine the channel pattern formation and dynamics of low-energy rivers. The lateral stability of most low-energy rivers is enhanced by their low width-depth ratio, which is commonly below 10 and results from the high bank strength. Rivers with a low width-depth ratio have an overdamped regime, meaning that when a bar forms in response to a local perturbation, the bar disappears within a short distance of the perturbation. A perturbation in one bend does not necessarily lead to a perturbation in the consecutive downstream bend, therefore rivers with an overdamped regime strongly differ from meandering rivers, which have an underdamped regime. An overdamped regime enhances the lateral stability of the river, in addition to the bank strength that leads to the low width-depth ratio. Despite the overdamped regime, these rivers may still show traces of lateral displacement. Local conditions of bank strength and stream power determine the rate of bank erosion and direction of channel shifts for each river bend in low-energy rivers, independent of the conditions at upstream or downstream bends.

Based on these insights and earlier efforts by others, I developed a channel pattern prediction tool (Ch. 5). Hitherto, channel patterns have often been predicted using morphometric parameters and parameters that depend on the actual channel pattern and morphology, which invalidates the prediction. Additionally, many of these predictors have low success rates in discriminating channel patterns of sand-bed rivers, because floodplain properties are not included. The prediction tool that was developed in this research uses parameters independent of channel pattern and includes the floodplain properties. The parameters used are median bed grain size, effective channel-forming discharge, valley slope and the average silt-plus-clay fraction of the river banks (Figure 5.6). In addition, I added an additional channel pattern class of self-constraining rivers with scroll bars and tortuous channel patterns, based on the Dommel River case study (Ch. 3). The overall prediction success improved compared to existing methods, 
especially for sand-bed rivers. This tool can be used to predict channel patterns of alluvial rivers and changes of channel pattern.

Channel patterns of low-energy rivers may change, e.g. due to land use or climate change, as illustrated in the channel pattern predictor diagram (Figures 6.3 and 6.4). Meandering rivers may change into laterally stable rivers when their stream power drops, or when they are subjected to relatively rapid overloading with cohesive sediments. They may also change into self-constraining rivers when stream power slightly drops, and cohesive deposits are preserved in the floodplain. Then the lateral migration does not stop at once, but gradually decreases with time (Figure 3.12). Spatial differences in bank strength or stream power also explain the longitudinal variation of channel pattern within rivers.

River restoration can benefit from the insights of this research and focus on restoring natural processes of low-energy rivers in a scientifically sound way. It is expected that limited river management is needed and the ecological state improves when geomorphological rules are obeyed in river restoration projects. Hence, river restoration should aim to restore the appropriate morphological processes, rather than to redesign the channel pattern according to a historical reference. Such process-based restoration can be reached by focussing on the key forming factors of channel pattern. The typology of low-energy rivers and the newly developed channel pattern predictor help to determine whether river reaches may have the potential to meander or are likely to be laterally stable. In this research, I showed that the sediment composition of the floodplain is key to predict the channel pattern and lateral river dynamics. Hence, the floodplain composition should be considered to prevent undesirable erosion, or provoke bank erosion when desired. River restoration also requires an understanding of the entire catchment, and should take into account future changes in climate and land use that affect the discharge regime to predict potential channel pattern changes. The typology of low-energy rivers can be used to elaborate on the potential for ecological recovery, because the river types differ in substrate, discharge regime, channel geometry, bank composition, bend sharpness, site turnover and flow patterns. 



\section{Samenvatting}

Op veel plekken in de wereld zijn rivieren gekanaliseerd gedurende de laatste eeuwen. Deze maatregelen zijn genomen om het land te draineren, om energie uit waterkracht te halen, om scheepvaart te verbeteren en om oever-erosie tegen te gaan. Echter, gedurende de laatste decennia realiseert men zich steeds vaker dat kanalisatie grote negatieve consequenties heeft: het resulteert in verlies aan ecologische waarde, verlaging van de grondwaterspiegel en hoge piekafvoeren die kunnen leiden tot overstromingen. Daarom worden rivieren tegenwoordig hersteld, vooral in Europa en Noord-Amerika. Eén van de meest gebruikte herstelmaatregelen in kleine, laag-energetische rivieren is het 'hermeanderen' van de riviergeul (Figuur 1.1). Deze maatregel houdt in dat de riviergeul weer slingerend aangelegd wordt, zoals op historische kaarten nog zichtbaar is, om zo de oorspronkelijke staat van rivieren te herstellen. Echter, de historische riviercondities waarop het ontwerp van hermeanderingsprojecten vaak wordt gebaseerd hoeven tegenwoordig niet meer van toepassing te zijn en het kan onmogelijk zijn deze te herstellen.

Dit onderzoek richt zich op kleine, laag-energetische rivieren waar de herstelmaatregel van hermeanderen op van toepassing is; rivieren met een specifiek stromingsvermogen $<10 \mathrm{~W} \mathrm{~m}^{-2}$ en een geulvullende afvoer $<200 \mathrm{~m}^{3} \mathrm{~s}^{-1}$. Meer in het bijzonder richt dit onderzoek zich op kleine, laag-energetische rivieren met één geul en één stroomdraad, die alluviaal zijn (i.e. ze vormen hun eigen overstromingsvlakte) en gelegen in een vallei. Zulke rivieren zijn in overvloed aanwezig op de Noordwest-Europese laaglandvlakte. Rivieren met een venige overstromingsvlakte worden in dit onderzoek ook beschouwd als alluviale rivieren.

Hoewel in herstelprojecten slingerende rivierpatronen gecreëerd worden, is het grotendeels onduidelijk hoe slingerende patronen van laag-energetische rivieren zich van nature vormen en zich ontwikkelen in de loop van de tijd. Veel laag-energetische rivieren hebben onvoldoende energie om hun oevers te eroderen, en laten weinig laterale migratie zien. Desondanks wordt er vaak veel ruimte gereserveerd in rivierherstelprojecten om de laag-energetische rivieren vrij te laten meanderen. Onder meanderen wordt verstaan het verplaatsen van de riviergeul, doordat buitenbochten eroderen onder invloed van de stroming en sediment in de binnenbocht wordt afgezet. Bovendien is het aangetoond dat de ecologische staat van rivieren niet verbetert wanneer de geomorfologische condities (bijvoorbeeld de sedimentsamenstelling van de ondergrond en het stromingsvermogen) worden genegeerd in hermeanderingsprojecten. Men realiseert zich steeds meer dat geomorfologische studies nodig zijn om inzicht te geven in het toekomstige rivierpatroon 
en zijn dynamiek. Naar aanleiding van dit soort studies kan de gewenste ecologische staat afgestemd worden op de geomorfologische condities.

In dit proefschrift is het mijn doel om het ontstaan van het geulpatroon van laagenergetische rivieren beter te begrijpen en te voorspellen. Deze kennis is nodig ten behoeve van rivierherstelprojecten. De doelstellingen van dit proefschrift zijn: 1) het definiëren van een typologie van laag-energetische rivieren, rekening houdende met hun geulpatroon, hun morfologie en de sedimentsamenstelling van de overstromingsvlakte, 2) het reconstrueren van de vorming van het geulpatroon voor verschillende laagenergetische rivieren, en het identificeren van de sleutelfactoren in de vorming van het geulpatroon, 3) het ontwikkelen van een geulpatroonvoorspeller voor verschillende typen laag-energetische rivieren, op basis van parameters die onafhankelijk zijn van het actuele geulpatroon.

Een overzicht van de opbouw van dit proefschrift is te zien in Figuur 1.4. The voornaamste focus van dit proefschrift ligt op de lange-termijnontwikkeling van de riviermorfologie $\left(10^{2}\right.$ tot $10^{3}$ jaren$)$, omdat ik verwacht dat geulpatroonveranderingen relatief langzaam gaan. Ik heb de vorming van het geulpatroon van drie verschillende rivieren onderzocht. Deze rivieren waren voornamelijk geselecteerd op basis van de valleivulling, omdat de sedimentsamenstelling van de overstromingsvlakte een groot effect zou kunnen hebben op de vorming van het geulpatroon. Deze rivieren variëren ook in grootte en in de samenstelling van hun valleiranden (Tabel 1.1). Ik heb laag-energetische rivieren geselecteerd met een venige (Hoofdstuk 2), heterogene (Hoofdstuk 3) en zandige (Hoofdstuk 4) valleivulling. Het geulpatroon van elk van deze rivieren was voldoende gepreserveerd om deze te reconstrueren voor de periode van voor de kanalisatie. De inzichten uit de studies van deze rivieren heb ik gebruikt om een algemeen toepasbare geulpatroonvoorspeller te ontwikkelen voor laag-energetische rivieren (Hoofdstuk 5).

De eerste onderzochte rivier (Hoofdstuk 2) is de Drentsche Aa die is gelegen in het noordelijk deel van Nederland (Figuur 2.1). De Drentsche Aa heeft een sterk slingerend patroon en ligt in een met veen gevulde vallei met zandige valleiranden. Het veen reikt tot $8 \mathrm{~m}$ diep, en begon te groeien aan het einde van het Laat-Glaciaal. Eerdere studies lieten zien dat de rivier lateraal stabiel is en het onbekend is hoe het hevige slingerende patroon is ontstaan. Ik heb data verzameld door boringen te zetten, grondradarprofielen te maken en geochronologische data te verzamelen in dwarsdoorsnedes in de vallei. Deze data heb ik gebruikt om een palaeogeografische reconstructie te maken. Op basis van deze reconstructie heb ik een conceptueel model ontwikkelt van hoe het geulpatroon zich vormde sinds het begin van de veengroei. Het conceptueel beschrijft de vorming van het patroon als volgt: het huidige patroon is het resultaat van diagonale aggradatie, wat een 
combinatie is van verticale aggradatie en laterale verplaatsing (Figuur 2.9). Tijdens de veengroei heeft de rivier de neiging om zich te hechten aan de valleiranden, omdat deze een lagere erosie-resistentie hebben dan de venige valleivulling. De overstromingsvlakte van de rivier wordt breder doordat de valleiranden eroderen, en omdat het veen groeit in een $\mathrm{V}$-vormige vallei. De hechting van de rivier aan de valleiranden in combinatie met het verbreden van de overstromingsvlakte resulteert in het langzaam uitrekken van de bochten van de rivier, waardoor de sinuositeit toeneemt. Hierbij ontstaat een zeer karakteristiek patroon, met rechthoekige bochten en relatief rechte stukken die de valleiranden volgen of de vallei oversteken (Figuur 2.9). Dit rivierpatroon is min of meer lateraal stabiel, omdat diagonale aggradatie een relatief langzaam proces is. Het typerende patroon is ook waargenomen op satellietbeelden voor andere venige rivieren in de wereld.

De tweede onderzochte rivier (Hoofdstuk 3) is de Dommel die is gelegen in het zuidelijk deel van Nederland (Figuur 3.2). Deze rivier ligt in een vallei met een heterogene vulling en relatief lemige valleiranden. Voor de kanalisatie had deze rivier een zeer complex patroon bestaande uit ongebruikelijk scherpe bochten met variabele grootte en abrupte, onregelmatige veranderingen van de geulrichting (i.e. een kronkelig patroon). Klassieke regelmatige meanderbochten ontbraken (Figuur 3.1a). Ik heb data verzameld door boringen te zetten, grondradarprofielen te maken en geochronologische data te verzamelen in dwarsdoorsnedes in de vallei. Op basis van deze data heb ik een palaeogeografische reconstructie gemaakt. Deze reconstructie heb ik gebruikt om een conceptueel model te ontwikkelen over hoe het kronkelige geulpatroon is ontstaan (Figuur 3.12). Het conceptuele model beschrijft de vorming van het patroon als volgt: de rivier bouwt zijn eigen overstromingsvlakte met zandige, niet-cohesieve pakketten, en lemige en venige cohesieve pakketten. De rivier heeft voldoende stromingsvermogen om de niet-cohesieve oevers te eroderen, maar onvoldoende om de cohesieve oevers te eroderen. Cohesieve afzettingen worden dus beter gepreserveerd dan niet-cohesieve afzettingen, waardoor de laterale mobiliteit van de rivier zeer laag is. Bochten migreren alleen maar lateraal waar de oever erodeerbaar is. De rivier legt zichzelf dus vast in deze door zichzelf gevormde heterogene overstromingsvlakte, en ontwikkelt zo een zeer onregelmatig, complex, kronkelig patroon. De neiging van de rivier om zichzelf vast te leggen wordt geïnitieerd zodra het stromingsvermogen afneemt, bijvoorbeeld door afname van piekafvoeren met veranderend landgebruik of klimaat. Doordat de relatieve hoeveelheid van cohesieve afzettingen toeneemt tijdens het vastleggen van de rivier, neemt het stromingsvermogen dat nodig is om uit deze positieve feedback van vastleggen te ontsnappen steeds verder toe. 
De derde onderzochte rivier (Hoofdstuk 4) is de Overijsselse Vecht die is gelegen in het oostelijk deel van Nederland (Figuur 4.1). Deze rivier ligt in een vallei met een zandige vulling en zandige valleiranden. De rivier is volledig gekanaliseerd sinds 1914, maar goed gepreserveerde palaeogeulen en kronkelwaarden zijn zichtbaar in de vallei. Ik heb data verzameld door boringen te zetten, grondradarprofielen te maken en geochronologische data te verzamelen in dwarsdoorsnedes in de vallei. Deze data heb ik gebruikt om een palaeogeografische reconstructie te maken. Op basis van deze reconstructie concludeerde ik dat de rivier veranderde van een lateraal stabiele naar een meanderende rivier rond 1400 tot 1500 . Ik reconstrueerde de geulvullende afvoer als functie van de tijd op basis van de kenmerken van de fluviatiele afzettingen, en liet zien dat een significante toename van de geulvullende afvoer de hoofdoorzaak was van de geulpatroonverandering (Figuren 4.9 en 4.11). Deze toename van de geulvullende afvoer werd waarschijnlijk veroorzaakt door de gecombineerde invloed van een klimaatfluctuatie (de Kleine IJstijd, 14e tot 19e eeuw), en veenontginning en -afgraving in het stroomgebied.

Naar aanleiding van de casestudy's kunnen laag-energetische rivieren gekarakteriseerd worden in vier verschillende types, op basis van hun karakteristieke geulpatroon, en de morfologie en sedimentsamenstelling van de overstromingsvlakte (Figuur 6.1, Tabel 6.1). 1) Meanderende rivieren hebben relatief regelmatige bochten, migreren lateraal en ontwikkelen een kronkelwaard. Deze rivieren hebben voldoende stromingsvermogen om hun overstromingsvlakte te eroderen. 2) Lateraal stabiele rivieren hebben een onregelmatig slingerend patroon met rechte stukken en af en toe scherpe bochten. Deze rivieren zijn lateraal stabiel, omdat het stromingsvermogen onvoldoende is om de overstromingsvlakte te eroderen. Het geulpatroon resulteert uit overerving van het vroegere geulpatroon en lokale verstoringen (bijvoorbeeld het omvallen van bomen). 3) Zichzelf-vastleggende rivieren hebben een kronkelend geulpatroon en laten lokale laterale migratie zien met kronkelwaardvorming. Deze rivieren hebben voldoende stromingsvermogen om niet-cohesieve afzettingen te eroderen, maar onvoldoende stromingsvermogen om cohesieve afzettingen te eroderen. 4) Diagonaal aggraderende rivieren hebben relatief rechthoekige bochten met rechte stukken ertussen. Deze rivieren hebben voldoende stromingsvermogen voor het eroderen van de zandige valleiranden, maar onvoldoende stromingsvermogen voor het eroderen van de venige valleivulling. De laatste twee riviertypes zijn voor het eerst gedefinieerd in dit proefschrift.

Op basis van de riviertypologie kan worden afgeleid dat de oeversterkte een sleutelfactor is in de ontwikkeling van het geulpatroon van laag-energetische rivieren. Omdat deze rivieren dicht bij de ondergrens zitten van voldoende stromingsvermogen voor oevererosie (Hoofdstuk 6), wordt het geulpatroon en de dynamiek bepaald door relatief kleine verschillen in de balans tussen het stromingsvermogen en oeversterkte. De 
laterale stabiliteit van de meeste laag-energetische rivieren wordt versterkt door de lage breedte-diepte-verhouding, die vaak lager is dan 10 als gevolg van de hoge oeversterkte. Rivieren met een lage breedte-diepte-verhouding hebben een overgedempt regime, wat betekent dat wanneer een bank zich vormt als reactie op een lokale verstoring, de bank zich slechts uitstrekt tot op korte afstand van deze verstoring. Een verstoring in de ene bocht leidt daarom niet noodzakelijkerwijs tot een verstoring in de opeenvolgende, benedenstroomse bocht. Daarom verschillen rivieren met een overgedempt regime sterk van meanderende rivieren, welke een ondergedempt regime hebben. Een overgedempt regime versterkt de laterale stabiliteit van de rivier, samen met de oeversterkte die leidt tot de lage breedte-diepte-verhouding. Ondanks het overgedempte regime kunnen deze rivieren nog steeds lokale laterale verplaatsing laten zien. Lokale condities van oeversterkte en stromingsvermogen bepalen de snelheid van oevererosie en richting van de geulverplaatsing voor elke bocht van laag-energetische rivieren, onafhankelijk van de condities in bovenstroomse of benedenstroomse bochten.

Op basis van de inzichten uit hoofdstukken 3 en 4 en vroegere inspanningen van anderen, heb ik een geulpatroonvoorspeller ontwikkeld (Hoofdstuk 5). Tot nu toe worden geulpatronen vaak voorspeld door gebruik te maken van parameters die afhankelijk zijn van het actuele geulpatroon en morfologie, wat de voorspelling in feite ongeldig maakt. Daarnaast zijn veel voorspellers weinig succesvol in het onderscheiden van geulpatronen van rivieren met een zandbedding, omdat de eigenschappen van de overstromingsvlakte niet meegenomen worden. De voorspeller die ontwikkeld is in dit onderzoek maakt gebruik van parameters die onafhankelijk zijn van geulpatroon en neemt de eigenschappen van de overstromingsvlakte wel mee. De gebruikte parameters zijn de mediane korrelgrootte van de bedding, de effectieve geulvormende afvoer, de valleihelling en de gemiddelde silt-plus-klei-fractie van de oevers (Figuur 5.6). Daarnaast heb ik een klasse van geulpatronen toegevoegd van zichzelf-vastleggende rivieren met kronkelwaarden en kronkelende geulpatronen, op basis van de casestudy van de Dommel (Hoofdstuk 3). Het succes van de voorspelling is verbeterd ten opzichte van bestaande methodes, vooral voor rivieren met een zandbedding. De geulpatroonvoorspeller kan gebruikt worden voor alluviale rivieren en kan ook veranderingen van geulpatroon voorspellen.

Geulpatronen van laag-energetische rivieren kunnen veranderen, bijvoorbeeld door landgebruiksveranderingen of klimaatveranderingen, zoals het geulpatroonvoorspellersdiagram illustreert (Figuren 6.3 en 6.4). Meanderende rivieren kunnen veranderen in lateraal stabiele rivieren wanneer hun stromingsvermogen afneemt, of wanneer ze relatief snel worden overladen met cohesieve sedimenten. Ze kunnen ook in zichzelf-vastleggende rivieren veranderen wanneer het stromingsvermogen lichtelijk 
afneemt, en cohesieve afzettingen gepreserveerd worden in de overstromingsvlakte. De laterale migratie stopt dan niet ineens, maar neemt geleidelijk af met de tijd (Figuur 3.12). Ruimtelijke verschillen in oeversterkte of stromingsvermogen verklaren ook de longitudinale variatie van geulpatronen binnen rivieren.

Rivierherstel kan profiteren van de inzichten uit dit onderzoek, en zou zich moeten richten op het herstellen van de natuurlijke processen van laag-energetische rivieren op een wetenschappelijk correcte wijze. Verwacht wordt dat relatief weinig rivierbeheer nodig is en de ecologische staat verbetert wanneer er in rivierherstelprojecten rekening wordt gehouden met de aanwezige geomorfologische condities. Dit betekent dat rivierherstel zich zou moeten richten op het herstellen van de passende morfologische processen, in plaats van op het herontwerpen van het geulpatroon volgens een historische referentie. Dit soort proces-gebaseerd herstel kan bereikt worden door te focussen op de sleutelfactoren van het geulpatroon. De typologie van laag-energetische rivieren en de nieuwe geulpatroonvoorspeller helpen om te bepalen of een stuk rivier de potentie heeft om te meanderen, of hoogstwaarschijnlijk lateraal stabiel zal zijn. In dit onderzoek liet ik zien dat de sedimentsamenstelling van de overstromingsvlakte essentieel is om het geulpatroon en de rivierdynamiek te voorspellen. Kennis van de samenstelling van de overstromingsvlakte zou gebruikt kunnen worden om ongewilde erosie te voorkomen, of om erosie op te wekken waar het gewenst is. Rivierherstel heeft ook begrip van het hele stroomgebied nodig, en zou rekening moeten houden met toekomstige veranderingen van het klimaat en landgebruik die het afvoerregime beïnvloeden, zodat potentiële rivierpatroonveranderingen voorspeld kunnen worden. De typologie van laag-energetische rivieren kan gebruikt worden om nauwgezet de potentie voor ecologisch herstel te bepalen, omdat de riviertypes verschillen in substraat, afvoerregime, geulgeometrie, oeversamenstelling, bochtscherpte, dynamiek en stromingspatronen. 


\section{Appendix I Original GPR profiles}

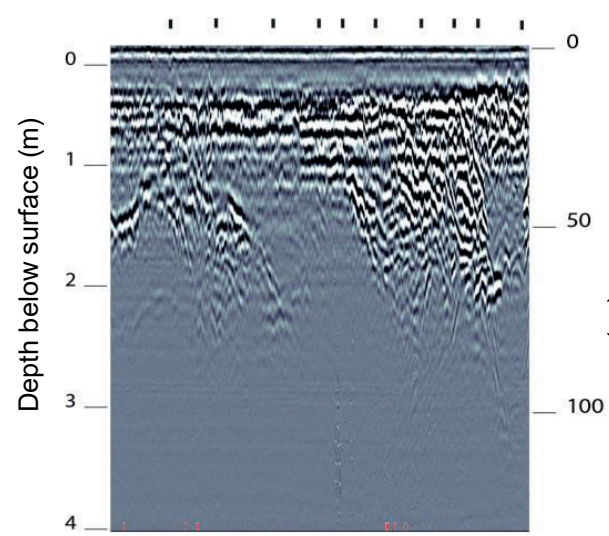

Figure A1.1 GPR profile Amen, 250Hz

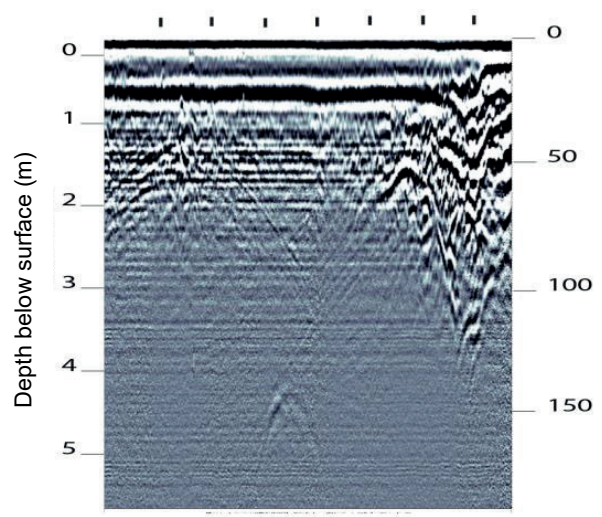

Figure A1.2 GPR profile Loon, $200 \mathrm{~Hz}$

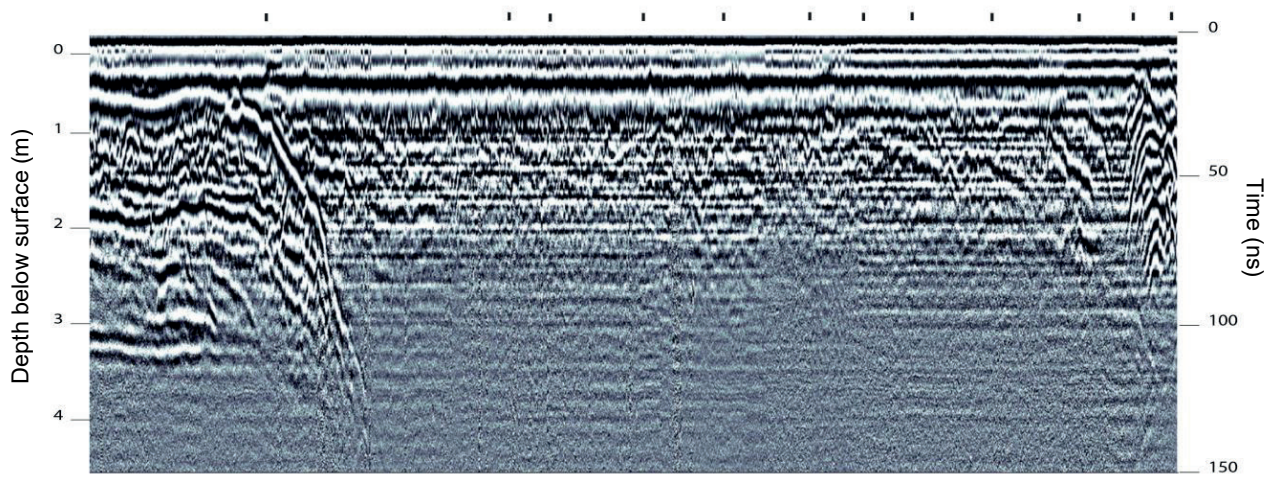

Figure A1.3 GPR profile Gasteren1 West, 200Hz 


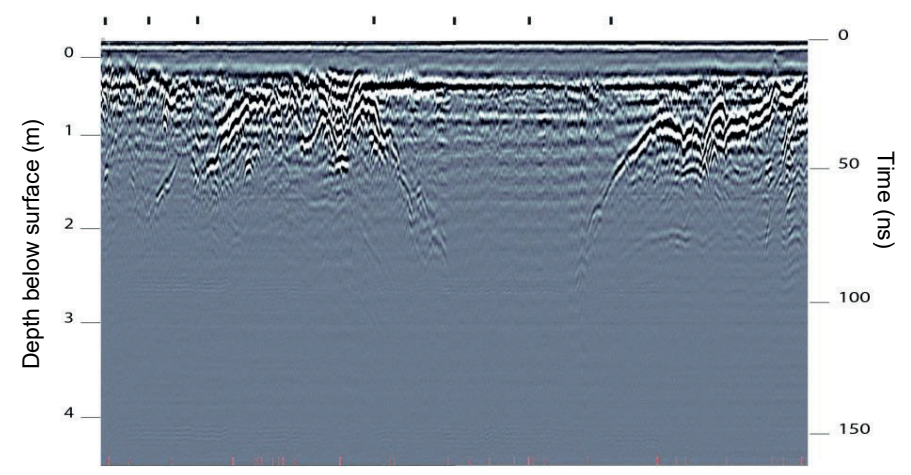

Figure A1.4 GPR profile Gasteren1 East, $250 \mathrm{~Hz}$

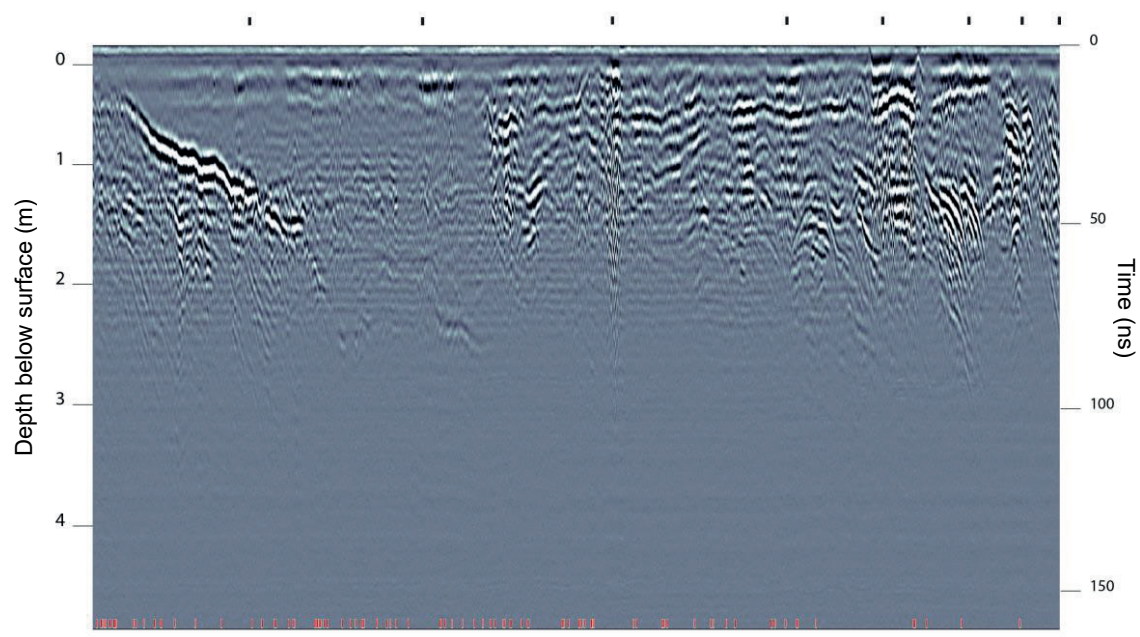

Figure A1.5 GPR profile Schipborg, $250 \mathrm{~Hz}$ 


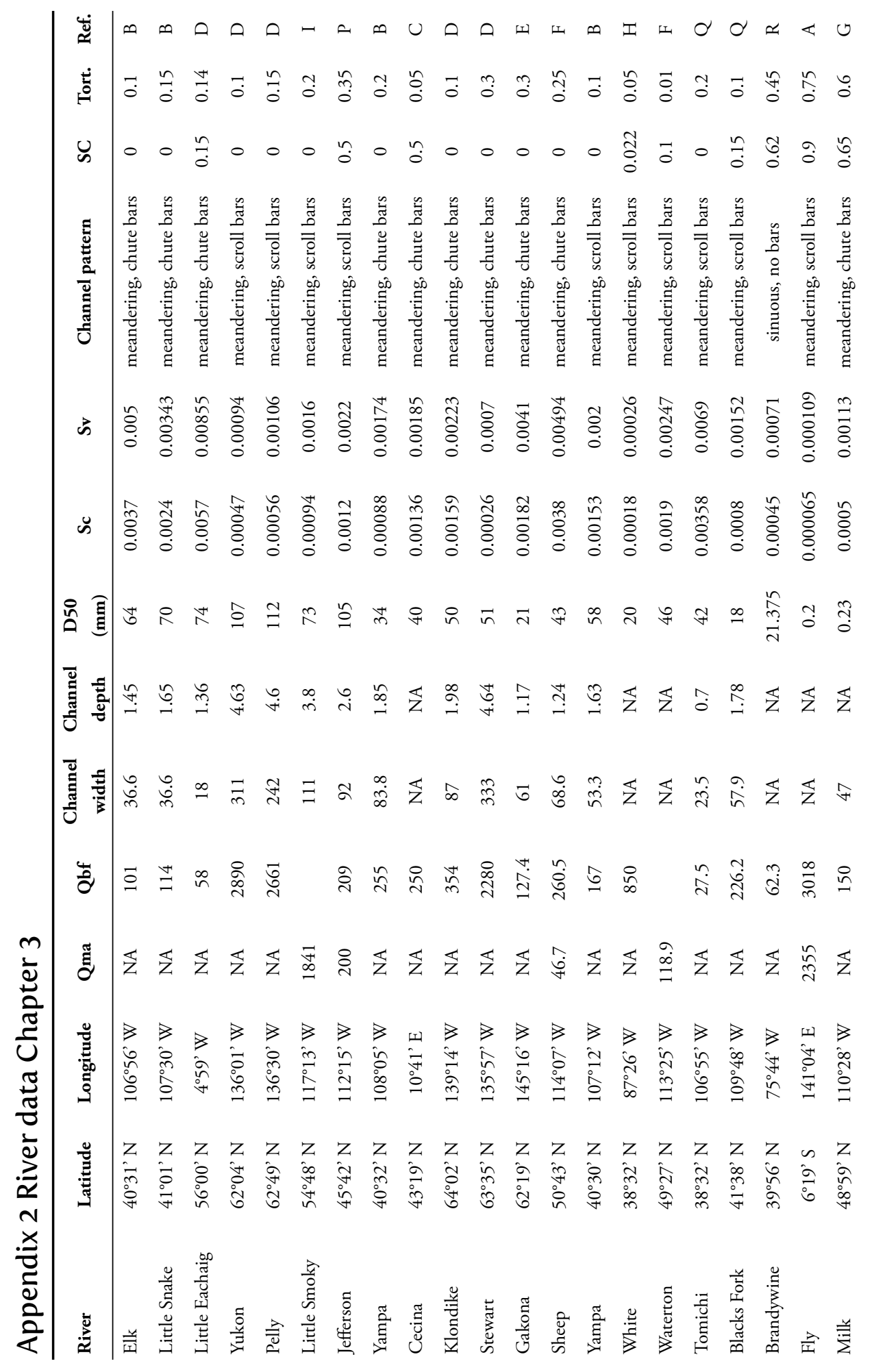




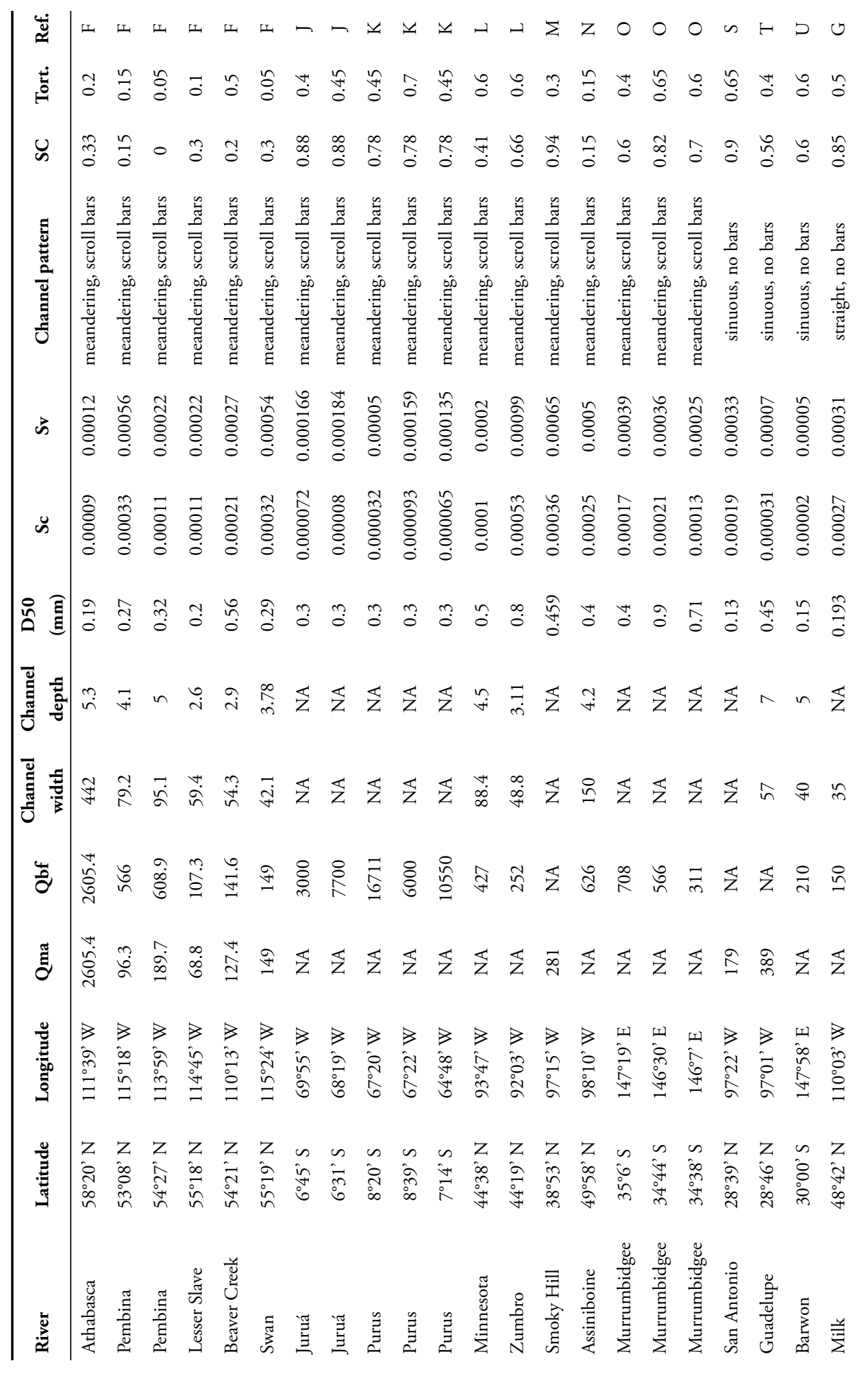




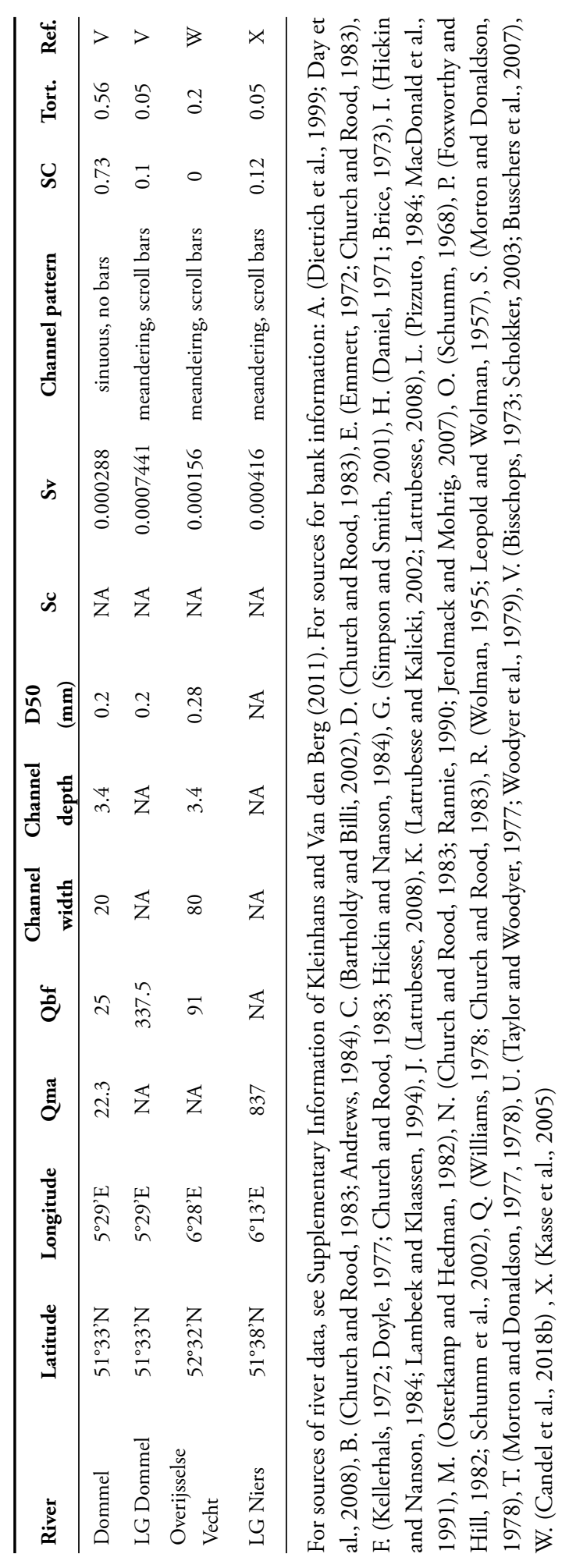


Appendix 3 Un-interpreted GPR transect of Palaeochannel X

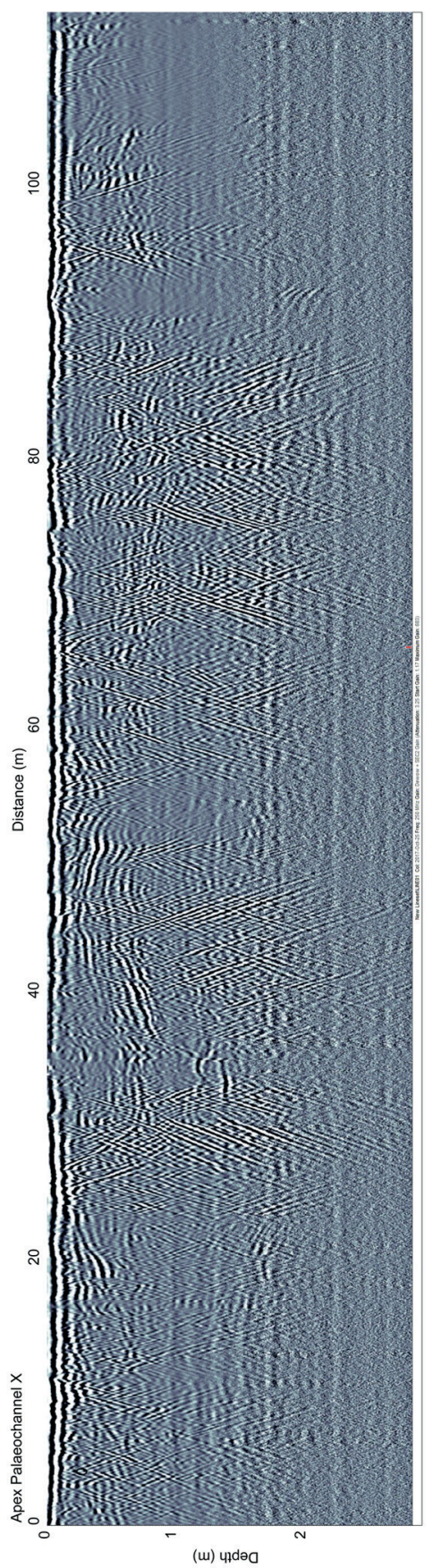




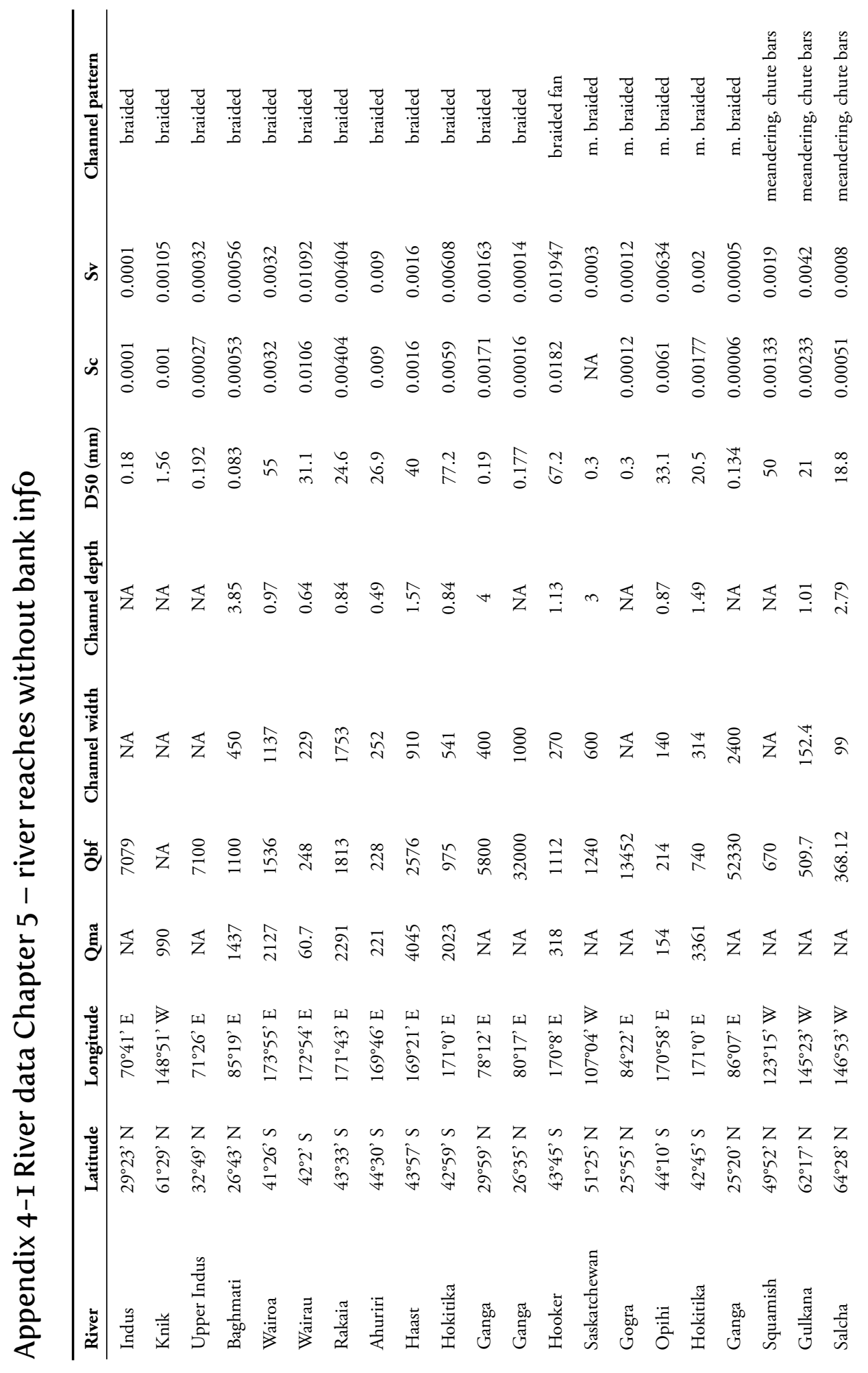




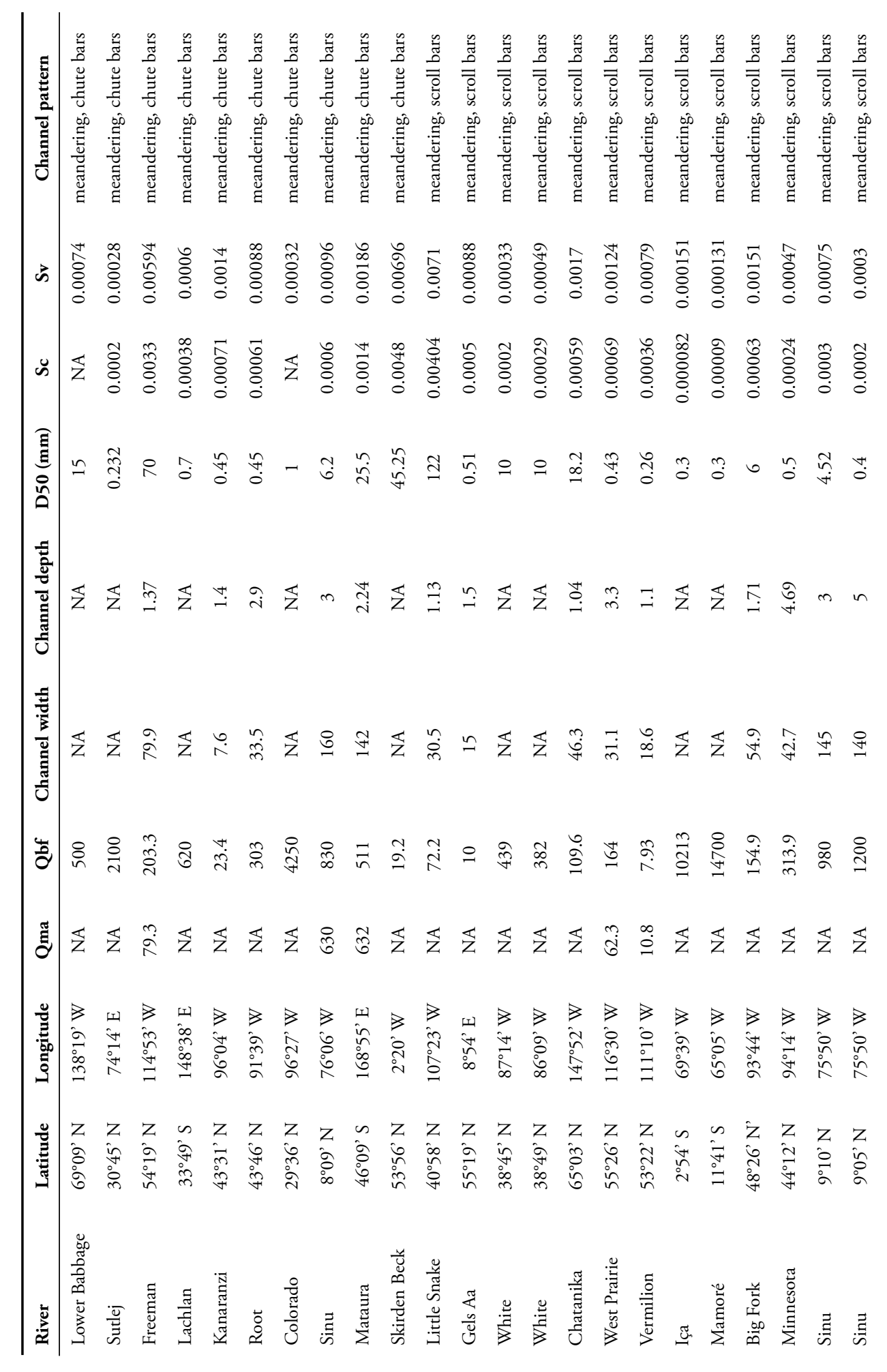




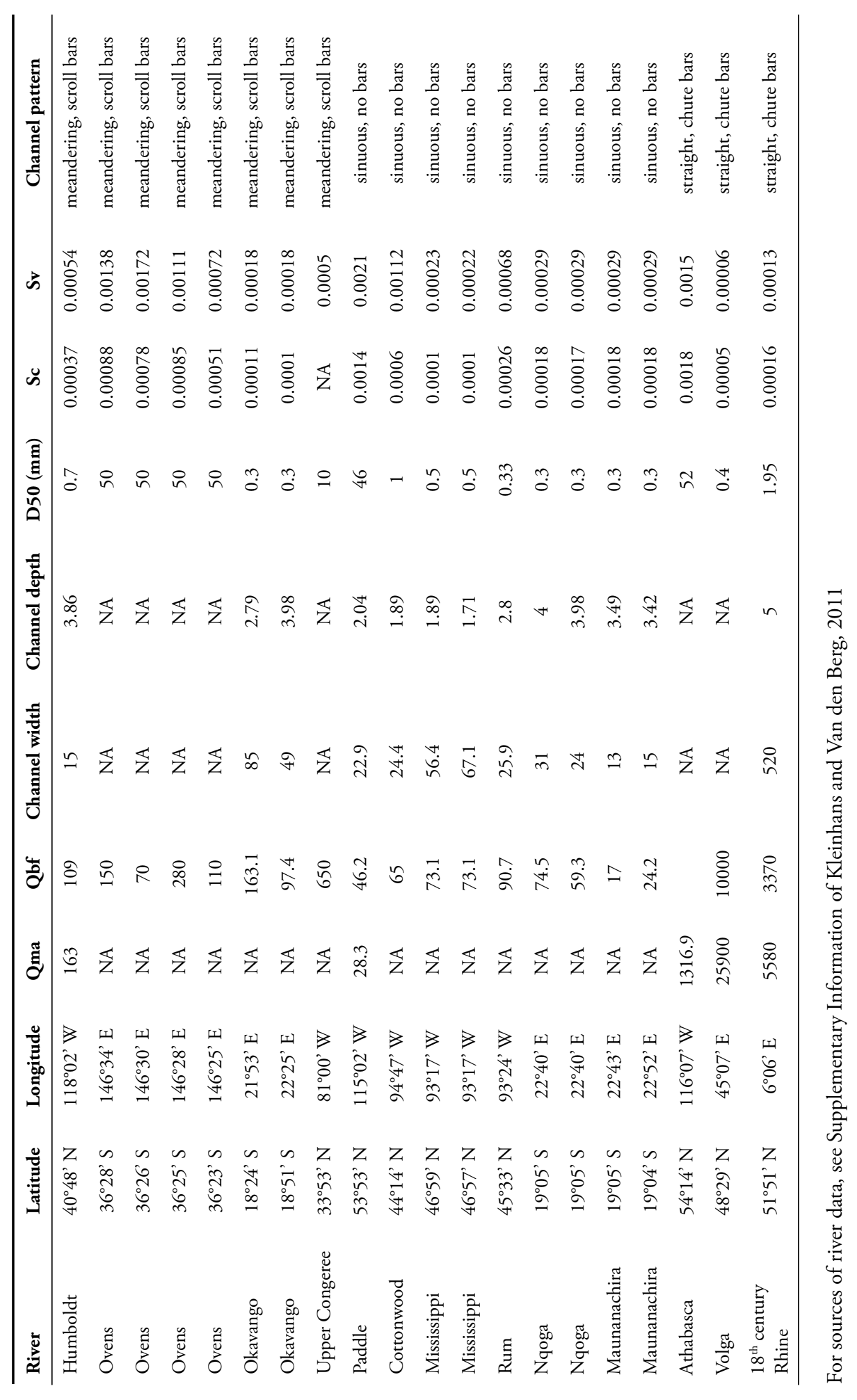




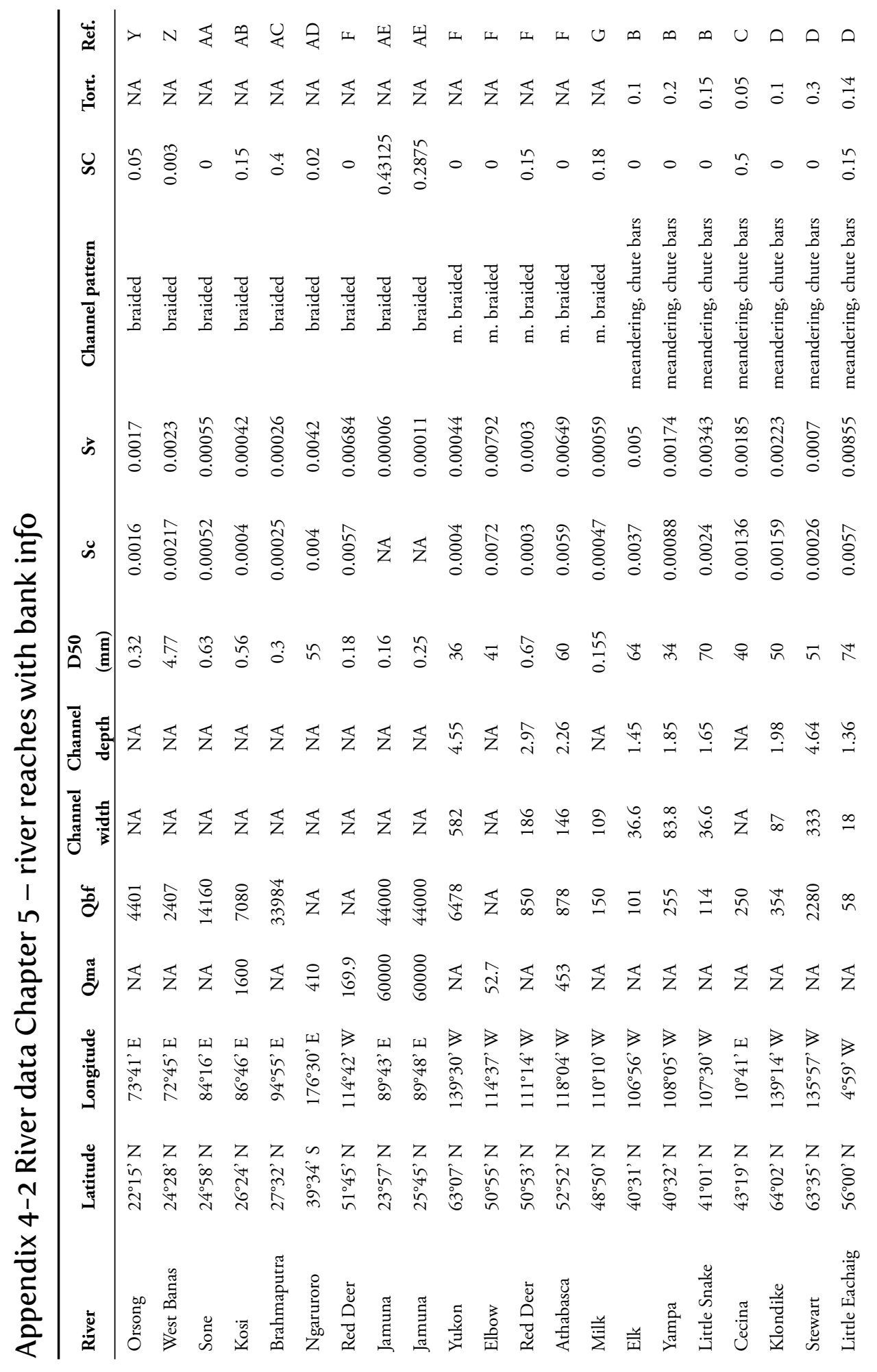




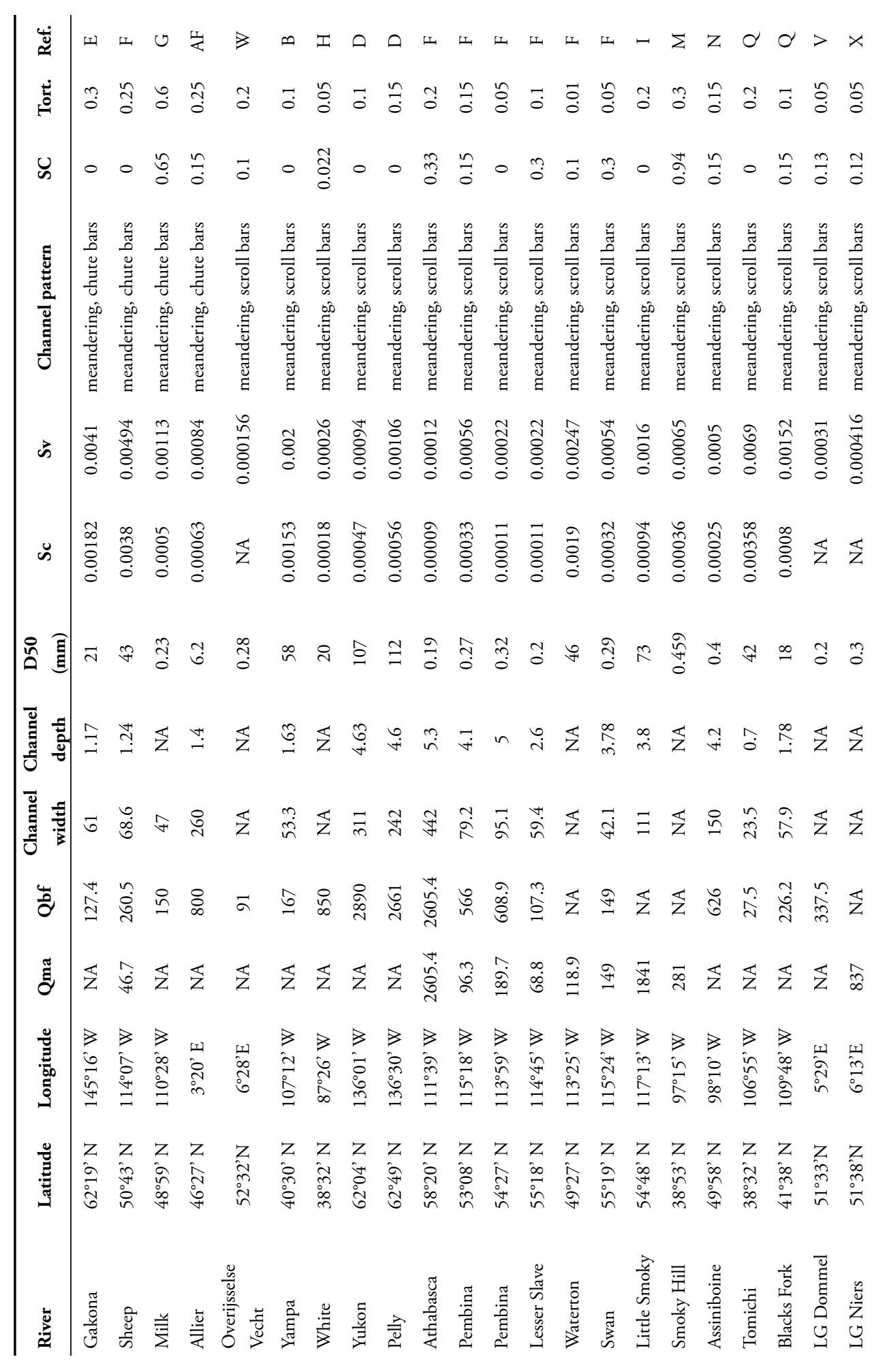




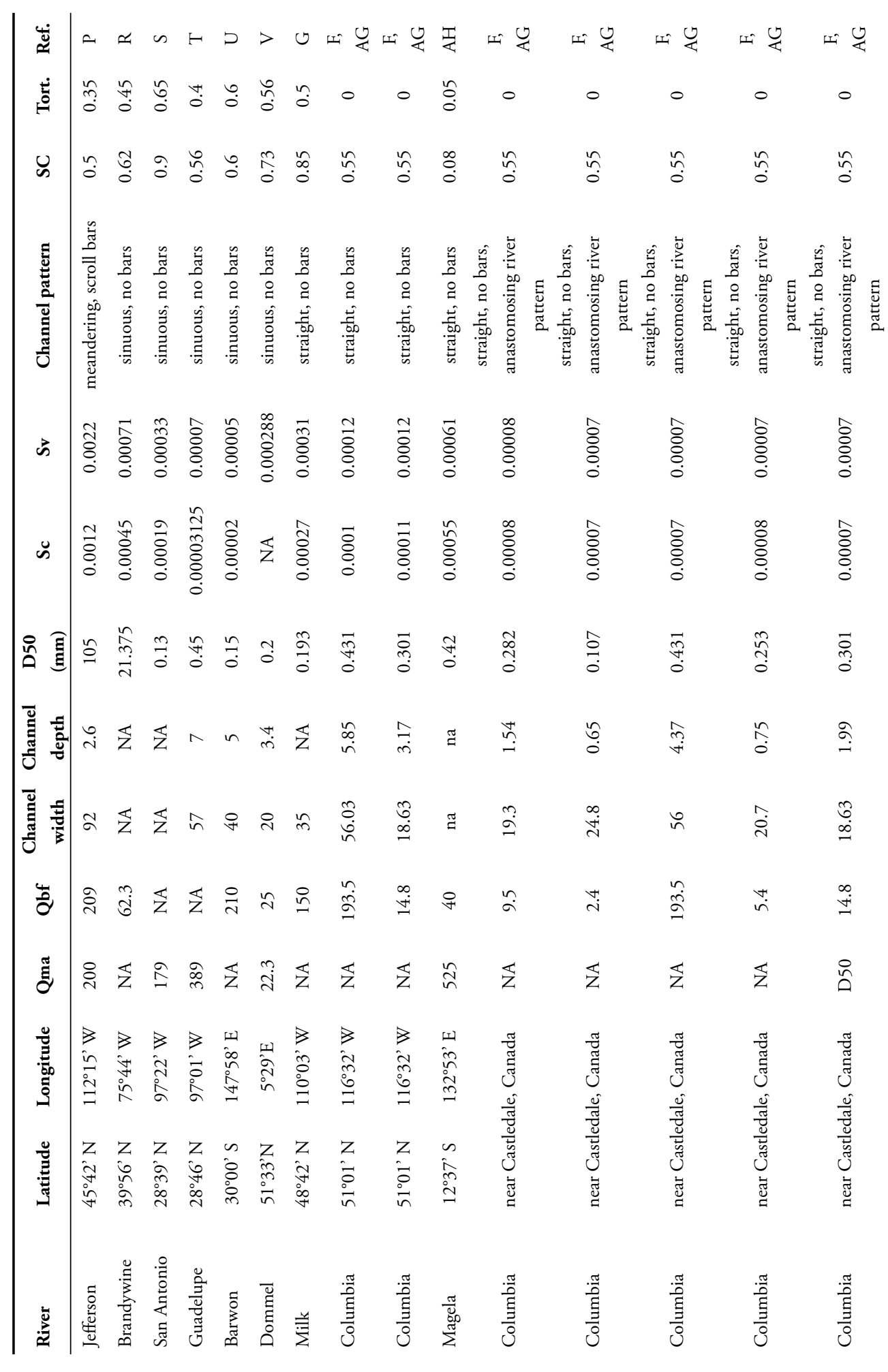




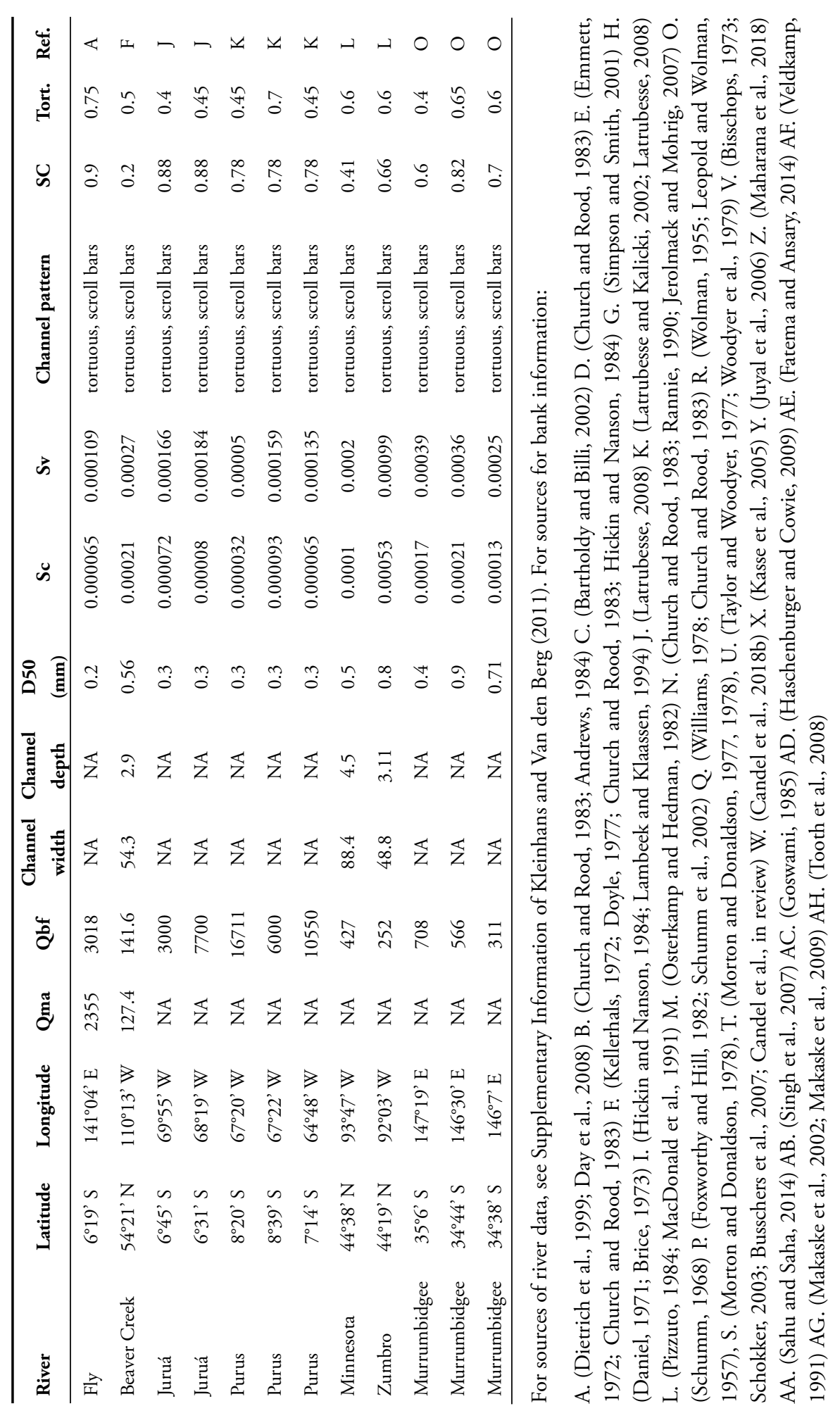




\section{Appendix 5 Discriminators}

\section{Physics-based channel pattern discriminator}

Flow and bed sediment have different longitudinal adaptation lengths over which they return to equilibrium after a perturbation (e.g. a river bend or object) (Crosato and Mosselman, 2009), because of gravitational effects on transverse and longitudinal slopes and because of spiral flows in bends (Kleinhans and Van den Berg, 2011). This difference in adaptation lengths results in the formation of bars in river bends, leading to a river bed topography in equilibrium. The ratio between the adaptation lengths determines the amount and type of bars that develop in a river channel cross-section (Crosato and Mosselman, 2009). The adaptation lengths of bed sediment $\left(\lambda_{\mathrm{s}, \mathrm{m}}\right)$ and water flow $\left(\lambda_{\mathrm{w}, \mathrm{m}}\right)$ are calculated following:

$$
\begin{aligned}
& \lambda_{s}=\frac{H}{\pi^{2}}\left(\frac{1}{m} \frac{W_{b f}}{H}\right)^{2} f(\theta) \\
& \lambda_{w}=\frac{C^{2} H}{2 g}
\end{aligned}
$$

where $m$ is the bar mode and $\mathrm{f}(\theta)$ is the magnitude of the transverse slope effect (-) defined by Talmon et al. (1995) and revised by Baar et al. (2018). Following the most recent insights by Baar et al. (2018), we take $f(\theta)=2$ for sand-bed rivers and $f(\theta)=3$ for gravel-bed rivers. The $\mathrm{C}$ is the Chézy coefficient $\left(\mathrm{m}^{0.5} \mathrm{~s}^{-1}\right)$. We calculated a median Chézy coefficient of $36 \mathrm{~m}^{0.5} \mathrm{~s}^{-1}$ for the entire dataset used in this study. We take the median, because we aim to estimate the discriminators that are generally applicable to the entire dataset rather than individual rivers, and the median was taken because it is less sensitive to extreme values compared to the average. The bar mode $m$ refers to the number of bars that form in a river channel cross-section (Parker, 1976; Struiksma et al., 1985; Crosato and Mosselman, 2009; Kleinhans and Van den Berg, 2011), with a bar mode of 1 meaning bars only form along the river channel sides. Higher bar modes refer to bars forming in the middle of the channel, and divide the river in multiple channels such as during braiding conditions. The bar mode can be translated to the braiding index $\left(\mathrm{B}_{\mathrm{i}}\right)$ by (Egozi and Ashmore, 2008; Crosato and Mosselman, 2009):

$$
B_{i}=\frac{m-1}{2}+1
$$

where $B_{i}$ refers to the number of active channels across the river width during channelforming discharge (Egozi and Ashmore, 2008). 
The ratio between $\lambda_{\mathrm{s}}$ and $\lambda_{\mathrm{w}}$ is indicated by the non-dimensional interaction parameter (IP), which strongly depends on the width-depth ratio, and indicates at what distance bars damp out after the perturbation (Struiksma et al., 1985). The IP can be calculated by:

$I P=\frac{\lambda_{s}}{\lambda_{w}}=\frac{2 g f(\theta)}{C^{2} \pi^{2}}\left(\frac{1}{m} \frac{W_{b f}}{H}\right)^{2}$

A low IP or width-depth ratio means that the bar regime is overdamped; when a bar forms in response to a local perturbation the bar does not affect the formation of bed forms further downstream, and the bar will extend only a short distance from the perturbation (Struiksma et al., 1985). An overdamped regime results in very stable conditions, and likely associates with a laterally stable channel pattern (Kleinhans and Van den Berg, 2011). An overdamped regime with laterally stable channel conditions occurs when:

$$
I P \leq \frac{2}{n+1+2 \sqrt{2 n-2}}
$$

where $\mathrm{n}$ is the degree of nonlinearity of sediment transport versus depth-averaged flow velocity (-), based on the relation given by (Crosato and Mosselman, 2009):

$$
n=3 \frac{\theta_{b f}}{\theta_{b f}-\theta_{c}}
$$

where $\theta_{b f}$ is the bankfull boundary Shields number (-) and $\theta_{c}$ is the critical Shields stress (-) defined by the Shields relation, lowered to represent beginning of motion (Soulsby, 1997, p. 106; Zanke, 2003):

$\theta_{c}=0.5\left(\frac{0.3}{1+1.2 D_{*}}+0.055\left(1-e^{-0.02 D_{*}}\right)\right)$

where $\mathrm{D}^{*}$ is the dimensionless grain size (-):

$$
D^{*}=D_{50}\left(\frac{\left(\frac{\rho_{S}}{\rho}-1\right) g}{v^{2}}\right)^{1 / 3}
$$

where $v$ is the kinematic viscosity of water $\left(\mathrm{m}^{2} \mathrm{~s}^{-1}\right), \rho$ is the water density $\left(\mathrm{kg} \mathrm{m}^{-3}\right)$, and $\rho_{\mathrm{s}}$ is the sediment density $\left(\mathrm{kg} \mathrm{m}^{-3}\right)$. 


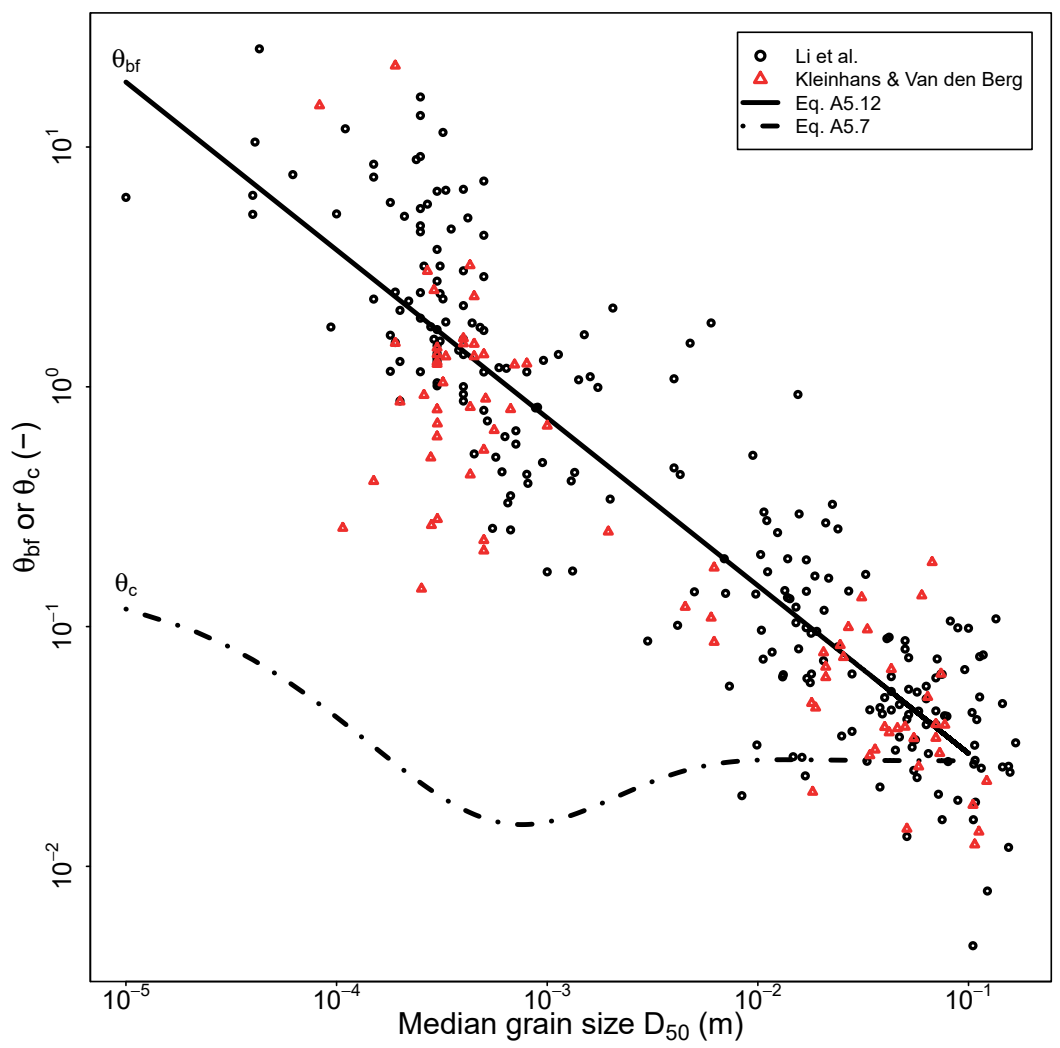

Figure A5.1 Data of 231 rivers by Li et al. (2015) and 77 rivers by Kleinhans \& Van den Berg (2011), showing the approximate relation between $\theta_{b f}$ and $\mathrm{D}_{50}$. Equation $\mathrm{A} 5.12$ gives the power relation given by the solid line $\left(\mathrm{R}^{2}=0.81\right)$. Equation A5.7 gives the critical Shields stress given by the dashed line.

At medium IP or width-depth ratio the bar regime becomes underdamped, leading to overdeepening of the outer bend pool and enhancement of bars on the inner bend and the formation of bars further downstream of the perturbation. This bar regime can be associated with a meandering channel pattern (Kleinhans and Van den Berg, 2011) and can be determined by:

$$
\frac{2}{n+1+2 \sqrt{2 n-2}}<I P<\frac{2 m^{2}}{n-3}
$$

A higher IP or width-depth ratio results in a positive feedback between the flow and deforming bed, leading to instability and consequently a braided channel pattern (excitation) (Kleinhans and Van den Berg, 2011). Braiding occurs when

$$
I P \geq \frac{2 m^{2}}{n-3}
$$


Crosato and Mosselman (2009) and Kleinhans and Van den Berg (2011) assumed n = 4 for sand-bed rivers and $n=10$ for gravel-bed river. However, here we further derive the equations by solving Eq. A5.6 partly empirically, which results in a channel pattern predictor that can be used in relation to the median bed material grain size rather than only for two classes (sand-bed and gravel-bed). Because Eq. A5.6 will be derived empirically, the newly developed discriminator should be interpreted as semi-physical.

Dade and Friend (1998) and Li et al. (2015) indicated that the $\theta_{b f}$ decreases with an increasing median bed material grain size $\left(\mathrm{D}_{50}\right)$, and the latter showed that this trend exists for a large range of $\mathrm{D}_{50}$, from 0.04 to $168 \mathrm{~mm}$ (Figure A5.1). They calculated $\theta_{b f}$ from a large dataset of rivers (Shields, 1936):

$$
\theta_{b f}=\frac{H S_{c}}{\frac{\left(\rho_{S}-\rho\right)}{\rho} D_{50}}
$$

Based on the data by Li et al. (2015) and Kleinhans and Van den Berg (2011), we could derive the following empirical equation for $\theta_{b f}$ (Figure A5.1):

$$
\theta_{b f}=0.006 D_{50}^{-0.7}
$$

Substitution of Eq. A5.12 in Eq. A5.6, and then in Eq. A5.5, A5.9 or A5.10, and then in Eq. A5.4 results in an equation for the width-depth ratio as a function of $\mathrm{D}_{50}$ at which the regime becomes overdamped (i.e. laterally stable), underdamped (i.e. meandering with scrolls) or in excitation (i.e. meandering with chutes, moderately braided or highly braided), given by Eq. A5.13 and Eq.A5.14 and Figure 5.4:

$$
\begin{aligned}
& \left(\frac{W_{b f}}{H}\right)_{i a}=\sqrt{\left(\frac{C^{2} \pi^{2}}{g \mathrm{f}(\theta)\left(1+\frac{0.0171 D_{50}^{-0.72}}{0.0057 D_{50}^{-0.72}-\theta_{c}}+2 \sqrt{\left(\frac{0.0342 D_{50}^{-0.72}}{0.0057 D_{50}^{-0.72}-\theta_{c}}-2\right)}\right)}\right)} \\
& \left(\frac{W_{b f}}{H}\right)_{s c \& b m}=m \sqrt{\left(\frac{C^{2} \pi^{2}}{g \mathrm{f}(\theta)\left(\frac{0.0171 D_{50}^{-0.72}}{0.0057 D_{50}^{-0.72}-\theta_{c}}-3\right)}\right)}
\end{aligned}
$$




\section{Consistency of slope of discriminators by Kleinhans and Van den Berg (20II)}

To confirm the slope of the discriminators as shown in Figure 5.2d, we used Eq. A5.12 to derive a relation between $\omega_{b f}$ and $\mathrm{D}_{50}$. Firstly, the $\theta_{b f}$ can be transformed to bankfull boundary shear stress $\left(\tau_{b f}\right)$ by (Shields, 1936; Li et al., 2015):

$\tau_{b f}=\theta_{b f} g\left(\rho_{s}-\rho\right) D_{50}$

Substitution of Eq. A5.12 in Eq. A5.15 results in:

$\tau_{b f}=95 D_{50}^{0.3}$

Kleinhans and Van den Berg (2011) gave a derivation of the actual stream power, $\omega_{\text {ac }}$ from the $\tau_{b f}$ by:

$\omega_{a c}=\frac{\tau_{b f}^{1.5} C}{\sqrt{\rho g}}$

Substitution of Eq. A5.16 in Eq. A5.17 results in:

$\omega_{a c}=1.5 E 2 * D_{50}^{0.45}$

Equation A5.18 gives an independent derivation of actual stream power as function of $\mathrm{D}_{50}$. The slope defined by Eq. A5.18 matches the slope of the discriminators defined by Eqs. 5.6 to 5.8 (main text) relatively well. However, Eq. A5.18 is a derivation of the actual stream power instead of the potential specific stream power as used in Eqs. 5.6 to 5.8. The data by Li et al. (2015) contained information merely on the channel slope rather than the valley slope, therefore only the actual stream power could be derived from their data (see Eq. A5.11). We performed the same analysis to calculate the $\omega_{p o t}$ using the valley slope with only the dataset of Kleinhans and Van den Berg (2011), and found that the direction of Eq. A5.18 did not change, but only the scaling factor (a factor 1.6 higher for the $\omega_{\text {pot }}$ then for the $\omega_{\mathrm{ac}}$ ). Hence, we can confirm the direction of the discriminators as defined by Kleinhans and Van den Berg (2011) in Eqs. 5.6 to 5.8. 


\section{References}

Agrawal, Y., I. McCave, and J. Riley, 1991, Laser diffraction size analysis, Principles, methods, and application of particle size analysis: New York, Cambridge University Press, p. 119-128. Aitken, M. J., 1985. Thermoluminescence dating, Academic press.

Aitken, M. J., 1998. Introduction to optical dating: the dating of Quaternary sediments by the use of photon-stimulated luminescence, Clarendon Press.

Akhtar, M., N. Sharma, and C. Ojha, 2011. Braiding process and bank erosion in the Brahmaputra River: International Journal of Sediment Research, v. 26, p. 431-444.

Aldous, A., P. McCormick, C. Ferguson, S. Graham, and C. Craft, 2005. Hydrologic regime controls soil phosphorus fluxes in restoration and undisturbed wetlands: Restoration Ecology, v. 13, p. 341-347.

Allen, J. R. L., 1965, The sedimentation and palaeogeography of the Old Red Sandstone of Anglesey, north Wales: Proceedings of the Yorkshire Geological and Polytechnic Society, p. 139-185.

Andrews, E. D., 1984. Bed-material entrainment and hydraulic geometry of gravel-bed rivers in Colorado: Geological Society of America Bulletin, v. 95, p. 371-378.

Archer, D., 1992. Land of Singing Waters-rivers and great floods of Northumbria: Stocksfield, Spredden Press.

Armitage, P., K. Lattmann, N. Kneebone, and I. Harris, 2001. Bank profile and structure as determinants of macroinvertebrate assemblages—seasonal changes and management: Regulated Rivers: Research \& Management: An International Journal Devoted to River Research and Management, v. 17, p. 543-556.

Baar, A. W., J. de Smit, W. S. Uijttewaal, and M. G. Kleinhans, 2018. Sediment transport of fine sand to fine gravel on transverse bed slopes in rotating annular flume experiments: Water Resources Research, v. 54, p. 19-45.

Baden, W., and R. Eggelsmann, 1964. Der wasserkreislauf eines nordwestdeutschen hochmoores: The water balance of a high moor in northwest Germany. Sehriftenreihe des Kuratoriums fur Kulturbauwesen, v. 12, p. 156.

Baird, A. J., P. A. Eades, and B. W. Surridge, 2008. The hydraulic structure of a raised bog and its implications for ecohydrological modelling of bog development: Ecohydrology, v. 1, p. 289-298.

Barbour, J. R., 2008. The origin and significance of sinuosity along incising bedrock rivers: $\mathrm{PhD}$ thesis, Columbia University, New York.

Bartholdy, J., and P. Billi, 2002. Morphodynamics of a pseudomeandering gravel bar reach: Geomorphology, v. 42, p. 293-310.

Bätz, N., E. P. Verrecchia, and S. N. Lane, 2015. The role of soil in vegetated gravelly river braid plains: more than just a passive response?: Earth Surface Processes and Landforms, v. 40 , p. $143-156$. 
Beechie, T., and H. Imaki, 2014. Predicting natural channel patterns based on landscape and geomorphic controls in the Columbia River basin, USA: Water Resources Research, v. 50, p. 39-57.

Beechie, T. J., M. Liermann, M. M. Pollock, S. Baker, and J. Davies, 2006. Channel pattern and river-floodplain dynamics in forested mountain river systems: Geomorphology, v. 78, p. 124-141. http://dx.doi.org/10.1016/j.geomorph.2006.01.030

Behringer, W., 1999. Climatic change and witch-hunting: the impact of the Little Ice Age on mentalities: Climate Change, v. 43, p. 335-351.

Berendsen, H. J., and E. Stouthamer, 2000. Late Weichselian and Holocene palaeogeography of the Rhine-Meuse delta, The Netherlands: Palaeogeography, Palaeoclimatology, Palaeoecology, v. 161, p. 311-335.

Berendsen, H. J., and E. Stouthamer, 2001. Palaeogeographic development of the RhineMeuse delta, the Netherlands, Koninklijke van Gorcum.

Beschta, R. L., and W. Ripple, 2006. River channel dynamics following extirpation of wolves in northwestern Yellowstone National Park, USA: Earth Surface Processes and Landforms, v. 31, p. 1525-1539.

Beschta, R. L., and W. J. Ripple, 2012. The role of large predators in maintaining riparian plant communities and river morphology: Geomorphology, v. 157, p. 88-98.

Best, J., 2019. Anthropogenic stresses on the world's big rivers: Nature Geoscience, v. 12, p. 7-21.

Bisschops, J., 1973. Toelichtingen bij de geologische kaart van Nederland 1: 50.000 Blad Eindhoven Oost (51 Oost), Haarlem.

Black, B. A., J. T. Perron, D. Hemingway, E. Bailey, F. Nimmo, and H. Zebker, 2017. Global drainage patterns and the origins of topographic relief on Earth, Mars, and Titan: Science, v. 356, p. 727-731. 10.1126/science.aag0171

Blanckaert, K., M. G. Kleinhans, S. J. McLelland, W. S. Uijttewaal, B. J. Murphy, A. Kruijs, D. R. Parsons, and Q. Chen, 2013. Flow separation at the inner (convex) and outer (concave) banks of constant-width and widening open-channel bends: Earth Surface Processes and Landforms, v. 38, p. 696-716.

Blanckaert, K. C. F., 2011. Hydrodynamic processes in sharp meander bends and their morphological implications: Journal of Geophysical Research: Earth Surface, v. 116. 10.1029/2010jf001806

Bledsoe, B. P., and C. C. Watson, 2001. Logistic analysis of channel pattern thresholds: meandering, braiding, and incising: Geomorphology, v. 38, p. 281-300. http://dx.doi. org/10.1016/S0169-555X(00)00099-4

Blöschl, G., J. Hall, J. Parajka, R. A. Perdigão, B. Merz, B. Arheimer, G. T. Aronica, A. Bilibashi, O. Bonacci, and M. Borga, 2017. Changing climate shifts timing of European floods: Science, v. 357, p. 588-590.

Bogoni, M., M. Putti, and S. Lanzoni, 2017. Modeling meander morphodynamics over self-formed heterogeneous floodplains: Water Resources Research, v. 53, p. 5137-5157. 
Booth, D. B., A. H. Roy, B. Smith, and K. A. Capps, 2016. Global perspectives on the urban stream syndrome: Freshwater Science, v. 35.

Borger, G. J., 1992, Draining-digging-dredging; the creation of a new landscape in the peat areas of the low countries, in J. T. A. Verhoeven, ed., Fens and bogs in the Netherlands, v. 18, Geobotany, p. 131-171.

Bos, I. J., F. S. Busschers, and W. Z. Hoek, 2012. Organic-facies determination: a key for understanding facies distribution in the basal peat layer of the Holocene Rhine-Meuse delta, The Netherlands: Sedimentology, v. 59, p. 676-703.

Botch, M., K. Kobak, T. Vinson, and T. Kolchugina, 1995. Carbon pools and accumulation in peatlands of the former Soviet Union: Global Biogeochemical Cycles, v. 9, p. 37-46.

Bøtter-Jensen, L., C. Andersen, G. Duller, and A. Murray, 2003. Developments in radiation, stimulation and observation facilities in luminescence measurements: Radiation Measurements, v. 37, p. 535-541.

Bout, A. E., S. F. Pfau, E. v. d. Krabben, and B. Dankbaar, 2019. Residual Biomass from Dutch Riverine Areas-From Waste to Ecosystem Service: Sustainability, v. 11, p. 509.

Brewer, P., and J. Lewin, 1998. Planform cyclicity in an unstable reach: complex fluvial response to environmental change: Earth Surface Processes and Landforms, v. 23, p. 989-1008.

Brice, J., 1973, Meandering pattern of the White River in Indiana-an analysis, Fluvial geomorphology, v. 4, State University of New York at Binghamton Paris, p. 178-200.

Bridge, J. S., 1993. The interaction between channel geometry, water flow, sediment transport and deposition in braided rivers: Geological Society, London, Special Publications, v. 75, p. 13-71.

Bridgham, S. D., J. P. Megonigal, J. K. Keller, N. B. Bliss, and C. Trettin, 2006. The carbon balance of North American wetlands: Wetlands, v. 26, p. 889-916. 10.1672/0277-5212(2006)26[889:tcbona]2.0.co;2

Brierley, G., K. Fryirs, and V. Jain, 2006. Landscape connectivity: the geographic basis of geomorphic applications: Area, v. 38, p. 165-174.

Brierley, G., and K. Fryirs, 2009. Don't fight the site: three geomorphic considerations in catchment-scale river rehabilitation planning: Environmental Management, v. 43, p. 1201-1218.

Brierley, G. J., and K. Fryirs, 2000. River styles, a geomorphic approach to catchment characterization: Implications for river rehabilitation in Bega catchment, New South Wales, Australia: Environmental Management, v. 25, p. 661-679.

Brierley, G. J., and K. A. Fryirs, 2015. The Use of Evolutionary Trajectories to Guide 'Moving Targets' in the Management of River Futures: River Research and Applications, p. n/an/a. 10.1002/rra.2930

Bronk Ramsey, C., 2009. OxCal Program v4. 2, Online: http://www.rlaha.ox.ac.uk/orau/ oxcal.html. 
Brookes, A., K. J. Gregory, and F. H. Dawson, 1983. An assessment of river channelization in England and Wales: Science of The Total Environment, v. 27, p. 97-111. http://dx.doi. org/10.1016/0048-9697(83)90149-3

Brookes, A., 1988. Channelized rivers: Perspectives for Environmental Management. Chichester, John Wiley \& Sons.

Broothaerts, N., G. Verstraeten, B. Notebaert, R. Assendelft, C. Kasse, S. Bohncke, and J. Vandenberghe, 2013. Sensitivity of floodplain geoecology to human impact: A Holocene perspective for the headwaters of the Dijle catchment, central Belgium: The Holocene, v. 23, p. 1403-1414. 10.1177/0959683613489583

Broothaerts, N., G. Verstraeten, C. Kasse, S. Bohncke, B. Notebaert, and J. Vandenberghe, 2014a. From natural to human-dominated floodplain geoecology - A Holocene perspective for the Dijle catchment, Belgium: Anthropocene, v. 8, p. 46-58. http:// dx.doi.org/10.1016/j.ancene.2014.12.001

Broothaerts, N., B. Notebaert, G. Verstraeten, C. Kasse, S. Bohncke, and J. E. F. Vandenberghe, 2014b. Non-uniform and diachronous Holocene floodplain evolution: a case study from the Dijle catchment, Belgium: Journal of Quaternary Science, v. 29, p. 351-360. 10.1002/jqs.2709

Brown, A., and M. Keough, 1992. Holocene floodplain metamorphosis in the Midlands, United Kingdom: Geomorphology, v. 4, p. 433-445.

Brown, A., M. Keough, and R. Rice, 1994. Floodplain evolution in the East Midlands, United Kingdom: the Lateglacial and Flandrian alluvial record from the Soar and Nene valleys: Philosophical Transactions of the Royal Society of London A: Mathematical, Physical and Engineering Sciences, v. 348, p. 261-293.

Brown, A. G., L. Lespez, D. A. Sear, J.-J. Macaire, P. Houben, K. Klimek, R. E. Brazier, K. van Oost, and B. Pears, 2018. Natural vs anthropogenic streams in Europe: History, ecology and implications for restoration, river-rewilding and riverine ecosystem services: Earth-Science Reviews, v. 180, p. 185-205.

Brownlie, W. R., 1983. Flow depth in sand-bed channels: Journal of Hydraulic Engineering, v. 109, p. 959-990.

Burke, W., 1975. Effect of drainage on the hydrology of blanket bog: Irish Journal of Agricultural Research, v. 14, p. 145-162.

Burt, T., 1996. The hydrological role of floodplains within the drainage basin system: Buffer zones: their processes and potential in water protection, p. 21-32.

Busschers, F., H. Weerts, J. Wallinga, P. Cleveringa, C. Kasse, H. De Wolf, and K. Cohen, 2005. Sedimentary architecture and optical dating of Middle and Late Pleistocene RhineMeuse deposits-fluvial response to climate change, sea-level fluctuation and glaciation: Netherlands Journal of Geosciences, v. 84, p. 25-41. 
Busschers, F., C. Kasse, R. Van Balen, J. Vandenberghe, K. Cohen, H. Weerts, J. Wallinga, C. Johns, P. Cleveringa, and F. Bunnik, 2007. Late Pleistocene evolution of the RhineMeuse system in the southern North Sea basin: imprints of climate change, sea-level oscillation and glacio-isostacy: Quaternary Science Reviews, v. 26, p. 3216-3248.

Busschers, F. S., R. T. Van Balen, K. M. Cohen, C. Kasse, H. J. T. Weerts, J. Wallinga, and F. P. M. Bunnik, 2008. Response of the Rhine-Meuse fluvial system to Saalian ice-sheet dynamics: Boreas, v. 37, p. 377-398. 10.1111/j.1502-3885.2008.00025.x

Camporeale, C., P. Perona, A. Porporato, and L. Ridolfi, 2005. On the long-term behavior of meandering rivers: Water resources research, v. 41.

Camporeale, C., P. Perona, A. Porporato, and L. Ridolfi, 2007. Hierarchy of models for meandering rivers and related morphodynamic processes: Reviews of Geophysics, v. 45.

Camporeale, C., and L. Ridolfi, 2010. Interplay among river meandering, discharge stochasticity and riparian vegetation: Journal of Hydrology, v. 382, p. 138-144.

Candel, J. H. J., B. Makaske, J. E. A. Storms, and J. Wallinga, 2017. Oblique aggradation: a novel explanation for sinuosity of low-energy streams in peat-filled valley systems: Earth Surface Processes and Landforms, v. 42, p. 2679-2696. 10.1002/esp.4100

Candel, J. H. J., B. Makaske, N. Kijm, J. E. A. Storms, and J. Wallinga, 2018a. Decreasing lateral migration and increasing planform complexity of the Dommel River during the Holocene: NCR Days 2018 Proceedings, v. 42-2018, p. 32-33.

Candel, J. H. J., M. G. Kleinhans, B. Makaske, W. Z. Hoek, C. Quik, and J. Wallinga, 2018b. Late Holocene channel pattern change from laterally stable to meandering - a palaeohydrological reconstruction: Earth Surf. Dynam., v. 6, p. 723-741. https://doi. org/10.5194/esurf-6-723-2018

Candel, J. H. J., B. Makaske, N. Kijm, M. Kleinhans, J. E. A. Storms, and J. Wallinga, in review. Self-constraining of low-energy meandering rivers; a novel explanation for tortuous planforms and low mobility: The Depositional Record.

Candel, J. H. J., M. G. Kleinhans, B. Makaske, and J. Wallinga, submitted. Predicting river channel pattern based on stream power, bed material and bank strength: Progress in Physical Geography.

Carey, W. C., 1969. Formation of flood plain lands: Journal of the Hydraulics Division, v. 95, p. 981-994.

Carlston, C. W., 1965. The relation of free meander geometry to stream discharge and its geomorphic implications: American Journal of Science, v. 263, p. 864-885.

Carson, M., 1984. The meandering-braided river threshold: a reappraisal: Journal of Hydrology, v. 73, p. 315-334.

Casparie, W. A., and J. Streefkerk, 1992, Climatological, stratigraphic and palaeo-ecological aspects of mire development, in J. T. A. Verhoeven, ed., Fens and Bogs in the Netherlands: Vegetation, History, Nutrient Dynamics and Conservation, v. Geobotany 18: Dordrecht, Kluwer Academic Publishers, p. 85-133. 
Chang, H. H., 1985. River morphology and thresholds: Journal of Hydraulic Engineering, v. 111, p. $503-519$.

Church, M., and K. Rood, 1983. Catalogue of alluvial river channel regime data, Vancouver, B.C., University of British Columbia, Dep. of Geography, p. 99.

Church, M., 2002. Geomorphic thresholds in riverine landscapes: Freshwater biology, v. 47, p. 541-557.

Clymo, R. S., 1991. Peat growth: Quaternary landscapes, p. 76-112.

Cobb, D., T. Galloway, and J. Flannagan, 1992. Effects of discharge and substrate stability on density and species composition of stream insects: Canadian Journal of Fisheries and Aquatic Sciences, v. 49, p. 1788-1795.

Collas, F., A. Buijse, L. Van den Heuvel, N. Van Kessel, M. Schoor, H. Eerden, and R. Leuven, 2018. Longitudinal training dams mitigate effects of shipping on environmental conditions and fish density in the littoral zones of the river Rhine: Science of the Total Environment, v. 619, p. 1183-1193.

Constantine, J. A., T. Dunne, H. Piégay, and G. Mathias Kondolf, 2010. Controls on the alluviation of oxbow lakes by bed-material load along the Sacramento River, California: Sedimentology, v. 57, p. 389-407.

Conway, V., and A. Millar, 1960. The hydrology of some small peat-covered catchments in the northern Pennines: J. Instn Wat. Engrs, v. 14, p. 415-424.

Corenblit, D., E. Tabacchi, J. Steiger, and A. M. Gurnell, 2007. Reciprocal interactions and adjustments between fluvial landforms and vegetation dynamics in river corridors: A review of complementary approaches: Earth-Science Reviews, v. 84, p. 56-86. http:// dx.doi.org/10.1016/j.earscirev.2007.05.004

Corenblit, D., J. Steiger, A. M. Gurnell, and R. J. Naiman, 2009. Plants intertwine fluvial landform dynamics with ecological succession and natural selection: a niche construction perspective for riparian systems: Global Ecology and Biogeography, v. 18, p. 507-520.

Corenblit, D., N. S. Davies, J. Steiger, M. R. Gibling, and G. Bornette, 2015. Considering river structure and stability in the light of evolution: feedbacks between riparian vegetation and hydrogeomorphology: Earth Surface Processes and Landforms, v. 40, p. 189-207.

Coulthard, T. J., 2005. Effects of vegetation on braided stream pattern and dynamics: Water Resources Research, v. 41.

Crosato, A., 2009. Physical explanations of variations in river meander migration rates from model comparison: Earth Surface Processes and Landforms, v. 34, p. 2078-2086.

Crosato, A., and E. Mosselman, 2009. Simple physics-based predictor for the number of river bars and the transition between meandering and braiding: Water Resources Research, v. 45, p. W03424. doi:10.1029/2008WR007242

Cunningham, A., J. Wallinga, and P. Minderhoud, 2011. Expectations of scatter in equivalentdose distributions when using multi-grain aliquots for OSL dating: Geochronometria, v. 38 , p. 424-431. 
Cunningham, A. C., and J. Wallinga, 2010. Selection of integration time intervals for quartz OSL decay curves: Quaternary Geochronology, v. 5, p. 657-666.

Cunningham, A. C., and J. Wallinga, 2012. Realizing the potential of fluvial archives using robust OSL chronologies: Quaternary Geochronology, v. 12, p. 98-106.

Curtis, C., 1986. Controls on the precipitation of early diagenetic calcite, dolomite and siderite concretions in complex depositional sequences.

Dade, W. B., and P. F. Friend, 1998. Grain-size, sediment-transport regime, and channel slope in alluvial rivers: The Journal of geology, v. 106, p. 661-676.

Daniel, J. F., 1971. Channel movement of meandering Indiana streams, US Government Printing Office.

Day, G., W. E. Dietrich, J. C. Rowland, and A. Marshall, 2008. The depositional web on the floodplain of the Fly River, Papua New Guinea: Journal of Geophysical Research: Earth Surface, v. 113.

De Bakker, H., and J. Schelling, 1966. Systeem van bodemclassificatie voor Nederland. De hogere niveaus: Grondboor \& Hamer, v. 20, p. 229-229.

De Gans, W., 1981. The Drentsche Aa Valley System: A Study in Quaternary Geology. Dissertation, Vrije Universiteit van Amsterdam.

De Moor, J., C. Kasse, R. Van Balen, J. Vandenberghe, and J. Wallinga, 2008. Human and climate impact on catchment development during the Holocene-Geul River, the Netherlands: Geomorphology, v. 98, p. 316-339.

Dépret, T., E. Gautier, J. Hooke, D. Grancher, C. Virmoux, and D. Brunstein, 2017. Causes of planform stability of a low-energy meandering gravel-bed river (Cher River, France): Geomorphology, v. 285, p. 58-81. 10.1016/j.geomorph.2017.01.035

Derese, C., D. Vandenberghe, N. Eggermont, J. Bastiaens, R. Annaert, and P. Van den haute, 2010. A medieval settlement caught in the sand: Optical dating of sand-drifting at Pulle (N Belgium): Quaternary Geochronology, v. 5, p. 336-341. http://dx.doi.org/10.1016/j. quageo.2009.01.003

Dessie, M., N. E. Verhoest, T. Admasu, V. R. Pauwels, J. Poesen, E. Adgo, J. Deckers, and J. Nyssen, 2014. Effects of the floodplain on river discharge into Lake Tana (Ethiopia): Journal of Hydrology, v. 519, p. 699-710.

Dey, S., 2014, Fluvial processes: meandering and braiding, Fluvial hydrodynamics, Springer, p. 529-562.

Didderen, K., P. F. M. Verdonschot, R. M. A. Knegtel, and A. A. Besse-Lototskaya, 2009. Enquête beek(dal)herstelprojecten 2004-2008 : evaluatie van beekherstel over de periode 1960-2008 en analyse van effecten van 9 voorbeeldprojecten, Wageningen, Alterra, p. 77.

Dietrich, W., G. Day, and G. Parker, 1999. The Fly River, Papua New Guinea: Inferences about river dynamics, floodplain sedimentation and fate of sediment: Varieties of Fluvial Form, p. 345-376. 
dos Reis Oliveira, P. C., M. H. Kraak, P. F. Verdonschot, and R. C. Verdonschot, 2019. Lowland stream restoration by sand addition: Impact, recovery, and beneficial effects on benthic invertebrates: River Research and Applications, v. 35, p. 1023-1033.

Doyle, P. F., 1977. Hydrologic and hydraulic characteristics of the Athabasca River from Fort McMurray to Embarras: Edmonton, Alberta, Research Council of Alberta, Transportation and Surface Water Engineering Division.

Driessen, A. M. A. J., G. P. Van de Ven, and H. J. Wasser, 2000. Gij beken eeuwig vloeijend. Water in de streek van Rijn en IJssel: Utrecht, Matrijs.

Dufour, S., and H. Piégay, 2009. From the myth of a lost paradise to targeted river restoration: forget natural references and focus on human benefits: River Research and Applications, v. 25 , p. 568-581. 10.1002/rra.1239

Dunn, I. S., 1959. Tractive resistance of cohesive channels: Journal of the Soil Mechanics and Foundations Division, v. 85, p. 1-24.

Dury, G., 1973. Magnitude-frequency analysis and channel morphology: Fluvial Geomorphology: New York, State University of New York, p. 91-121.

Dyke, L. D., and W. E. Sladen, 2010. Permafrost and peatland evolution in the northern Hudson Bay Lowland, Manitoba: Arctic, p. 429-441.

Eaton, B. C., and R. G. Millar, 2004. Optimal alluvial channel width under a bank stability constraint: Geomorphology, v. 62, p. 35-45.

Eaton, B. C., and T. R. Giles, 2009. Assessing the effect of vegetation-related bank strength on channel morphology and stability in gravel-bed streams using numerical models: Earth Surface Processes and Landforms, v. 34, p. 712-724.

Eaton, B. C., R. G. Millar, and S. Davidson, 2010. Channel patterns: braided, anabranching, and single-thread: Geomorphology, v. 120, p. 353-364.

Edmaier, K., P. Burlando, and P. Perona, 2011. Mechanisms of vegetation uprooting by flow in alluvial non-cohesive sediment: Hydrology and Earth System Sciences, v. 15, p. 1615-1627.

Eekhout, J., A. Hoitink, and B. Makaske, 2013. Historical analysis indicates seepage control on initiation of meandering: Earth Surface Processes and Landforms, v. 38, p. 888-897.

Eekhout, J., R. Fraaije, and A. Hoitink, 2014. Morphodynamic regime change in a reconstructed lowland stream: Earth Surface Dynamics, v. 2, p. 279-293.

Eekhout, J., and A. Hoitink, 2015. Chute cutoff as a morphological response to stream reconstruction: The possible role of backwater: Water Resources Research, v. 51, p. 33393352.

Eekhout, J. P., A. J. Hoitink, J. H. de Brouwer, and P. F. Verdonschot, 2015. Morphological assessment of reconstructed lowland streams in the Netherlands: Advances in Water Resources, v. 81, p. 161-171.

Eekhout, J. P. C., 2014. Morphological processes in lowland streams : implications for stream restoration, Wageningen University, Wageningen.

Egozi, R., and P. Ashmore, 2008. Defining and measuring braiding intensity: Earth Surface Processes and Landforms, v. 33, p. 2121-2138. 
Emmett, W. W., 1972. The hydraulic geometry of some Alaskan streams south of the Yukon River, US Dept. of the Interior, Geological Survey, Water Resources Division, Alaska District.

Engelund, F., and E. Hansen, 1967. A monograph on sediment transport in alluvial streams, Tekniskforlag Skelbrekgade 4 Copenhagen V, Denmark.

Evette, A., C. Balique, C. Lavaine, F. Rey, and P. Prunier, 2012. Using ecological and biogeographical features to produce a typology of the plant species used in bioengineering for riverbank protection in Europe: River Research and Applications, v. 28, p. 1830-1842.

Eyles, R., 1977a. Birchams Creek: the transition from a chain of ponds to a gully: Australian Geographical Studies, v. 15, p. 146-157.

Eyles, R., 1977b. Changes in drainage networks since 1820, Southern Tablelands, NSW: Australian Geographer, v. 13, p. 377-386.

Fatema, N., and M. A. Ansary, 2014. Slope stability analysis of a Jamuna river embankment: Journal of Civil Engineering (IEB), v. 42, p. 119-136.

Ferguson, R., 1987, Hydraulic and sedimentary controls of channel pattern, in K. S. Richards, ed., River channels: environment and process: Oxford, U.K., Blackwell, p. 129-158.

Ferguson, R. I., D. R. Parsons, S. N. Lane, and R. J. Hardy, 2003. Flow in meander bends with recirculation at the inner bank: Water Resources Research, v. 39.

Finnegan, N. J., and W. E. Dietrich, 2011. Episodic bedrock strath terrace formation due to meander migration and cutoff: Geology, v. 39, p. 143-146.

Florsheim, J. L., J. F. Mount, and A. Chin, 2008. Bank erosion as a desirable attribute of rivers: BioScience, v. 58, p. 519-529.

Fohrer, N., S. Haverkamp, K. Eckhardt, and H.-G. Frede, 2001. Hydrologic response to land use changes on the catchment scale: Physics and Chemistry of the Earth, Part B: Hydrology, Oceans and Atmosphere, v. 26, p. 577-582.

Forzieri, G., L. Feyen, S. Russo, M. Vousdoukas, L. Alfieri, S. Outten, M. Migliavacca, A. Bianchi, R. Rojas, and A. Cid, 2016. Multi-hazard assessment in Europe under climate change: Climatic Change, v. 137, p. 105-119.

Fox, G. A., G. V. Wilson, A. Simon, E. J. Langendoen, O. Akay, and J. W. Fuchs, 2007. Measuring streambank erosion due to ground water seepage: correlation to bank pore water pressure, precipitation and stream stage: Earth Surface Processes and Landforms, v. 32, p. $1558-1573$.

Fox, G. A., D. M. Heeren, G. V. Wilson, E. J. Langendoen, A. K. Fox, and M. L. ChuAgor, 2010. Numerically predicting seepage gradient forces and erosion: Sensitivity to soil hydraulic properties: Journal of hydrology, v. 389, p. 354-362.

Foxworthy, B. L., and M. Hill, 1982. Volcanic eruptions of 1980 at Mount St. Helens: the first 100 days, USGPO.

Frascati, A., and S. Lanzoni, 2009. Morphodynamic regime and long-term evolution of meandering rivers: Journal of Geophysical Research: Earth Surface, v. 114. 
Fredsøe, J., 1978. Meandering and braiding of rivers: Journal of Fluid Mechanics, v. 84, p. 609-624.

Friedkin, J. F., 1945. Laboratory study of the meandering of alluvial rivers, U.S. Waterways Experiments Station, Vicksburg, Mississippi, p. 40.

Fujita, Y., 1989. Bar and channel formation in braided streams: River meandering, v. 12, p. 417-462.

Galbraith, R. F., R. G. Roberts, G. Laslett, H. Yoshida, and J. M. Olley, 1999. Optical dating of single and multiple grains of quartz from Jinmium rock shelter, northern Australia: Part I, experimental design and statistical models: Archaeometry, v. 41, p. 339-364.

Ganti, V., A. C. Whittaker, M. P. Lamb, and W. W. Fischer, 2019. Low-gradient, singlethreaded rivers prior to greening of the continents: Proceedings of the National Academy of Sciences, v. 116, p. 11652-11657. 10.1073/pnas.1901642116

Gaskin, S., J. Pieterse, A. A. Shafie, and S. Lepage, 2003. Erosion of undisturbed clay samples from the banks of the St. Lawrence River: Canadian Journal of Civil Engineering, v. 30, p. 585-595.

Geertsema, T. J., P. J. J. F. Torfs, A. J. Teuling, and A. J. F. Hoitink, in review. Wood-induced backwater in lowland streams: River Research and Applications.

Geertsema, T. J., B. Vermeulen, A. J. Teuling, and A. J. F. Hoitink, submitted. Transience of recirculations cells in sharp lowland river bends: Journal of Geophysical Research: Earth Surface.

Gerding, M., 1995. Vier eeuwen turfwinning: De verveningen in Groningen, Friesland, Drenthe en Overijssel tussen, v. 1550.

Ghinassi, M., A. Ielpi, M. Aldinucci, and M. Fustic, 2016. Downstream-migrating fluvial point bars in the rock record: Sedimentary Geology, v. 334, p. 66-96.

Gibling, M., 2018. River Systems and the Anthropocene: A Late Pleistocene and Holocene Timeline for Human Influence: Quaternary, v. 1, p. 21.

Gibling, M. R., and N. S. Davies, 2012. Palaeozoic landscapes shaped by plant evolution: Nature Geoscience, v. 5, p. 99-105.

Giriat, D., E. Gorczyca, and M. Sobucki, 2016. Beaver ponds' impact on fluvial processes (Beskid Niski Mts., SE Poland): Science of The Total Environment, v. 544, p. 339-353. http://dx.doi.org/10.1016/j.scitotenv.2015.11.103

Glaser, R., and H. Stangl, 2003. Historical floods in the Dutch Rhine delta: Natural Hazards and Earth System Science, v. 3, p. 605-613.

Glaser, R., D. Riemann, J. Schönbein, M. Barriendos, R. Brázdil, C. Bertolin, D. Camuffo, M. Deutsch, P. Dobrovolný, and A. van Engelen, 2010. The variability of European floods since AD 1500: Climatic Change, v. 101, p. 235-256.

Goswami, D. C., 1985. Brahmaputra River, Assam, India: Physiography, basin denudation, and channel aggradation: Water Resources Research, v. 21, p. 959-978. 
Grabowski, R. C., N. Surian, and A. M. Gurnell, 2014. Characterizing geomorphological change to support sustainable river restoration and management: Wiley Interdisciplinary Reviews: Water, v. 1, p. 483-512. 10.1002/wat2.1037

Gradziński, R., J. Baryła, M. Doktor, D. Gmur, M. Gradziński, A. Kędzior, M. Paszkowski, R. Soja, T. Zieliński, and S. Żurek, 2003. Vegetation-controlled modern anastomosing system of the upper Narew River (NE Poland) and its sediments: Sedimentary Geology, v. 157, p. 253-276. http://dx.doi.org/10.1016/S0037-0738(02)00236-1

Graf, W., P. Leitner, I. Hanetseder, L. Ittner, F. Dossi, and C. Hauer, 2016. Ecological degradation of a meandering river by local channelization effects: a case study in an Austrian lowland river: Hydrobiologia, v. 772, p. 145-160.

Grissinger, E., 1982. Bank erosion of cohesive materials: Gravel-bed rivers, p. 273-287.

Grove, J., 1988. The Little Ice Age, 498 pp: Methuen, London.

Guérin, G., N. Mercier, and G. Adamiec, 2011. Dose-rate conversion factors: update: Ancient TL, v. 29, p. 5-8.

Gumiero, B., J. Mant, T. Hein, J. Elso, and B. Boz, 2013. Linking the restoration of rivers and riparian zones/wetlands in Europe: Sharing knowledge through case studies: Ecological Engineering, v. 56, p. 36-50. http://dx.doi.org/10.1016/j.ecoleng.2012.12.103

Güneralp, İ., and B. L. Rhoads, 2011. Influence of floodplain erosional heterogeneity on planform complexity of meandering rivers: Geophysical Research Letters, v. 38, p. L14401.

Gurnell, A., H. Piegay, F. Swanson, and S. Gregory, 2002. Large wood and fluvial processes: Freshwater Biology, v. 47, p. 601-619.

Gurnell, A., M. Bussettini, B. Camenen, M. González del Tánago, R. Grabowski, D. Hendriks, A. Henshaw, A. Latapie, M. Rinaldi, and N. Surian, 2014. A hierarchical multiscale framework and indicators of hydromorphological processes and forms. Deliverable 2.1, Part 1, of REFORM (REstoring rivers FOR effective catchment Management), a collaborative project (large-scale integrating project) funded by the European Commission within the 7th Framework Programme under Grant Agreement 282656.

Gurnell, A., 2014. Plants as river system engineers: Earth Surface Processes and Landforms, v. 39, p. 4-25. 10.1002/esp.3397

Gurnell, A. M., 1998. The hydrogeomorphological effects of beaver dam-building activity: Progress in Physical Geography, v. 22, p. 167-189.

Gurnell, A. M., I. P. Morrissey, A. J. Boitsidis, T. Bark, N. J. Clifford, G. E. Petts, and K. Thompson, 2006. Initial adjustments within a new river channel: Interactions between fluvial processes, colonizing vegetation, and bank profile development: Environmental Management, v. 38, p. 580-596.

Gurnell, A. M., W. Bertoldi, and D. Corenblit, 2012. Changing river channels: The roles of hydrological processes, plants and pioneer fluvial landforms in humid temperate, mixed load, gravel bed rivers: Earth-Science Reviews, v. 111, p. 129-141. http://dx.doi. org/10.1016/j.earscirev.2011.11.005 
Gurnell, A. M., D. Corenblit, D. García de Jalón, M. González del Tánago, R. C. Grabowski, M. T. O’Hare, and M. Szewczyk, 2015. A Conceptual Model of Vegetationhydrogeomorphology Interactions Within River Corridors: River Research and Applications, p. n/a-n/a. 10.1002/rra.2928

Haschenburger, J. K., and M. Cowie, 2009. Floodplain stages in the braided Ngaruroro River, New Zealand: Geomorphology, v. 103, p. 466-475.

Hering, D., J. Aroviita, A. Baattrup-Pedersen, K. Brabec, T. Buijse, F. Ecke, N. Friberg, M. Gielczewski, K. Januschke, and J. Köhler, 2015. Contrasting the roles of section length and instream habitat enhancement for river restoration success: a field study of 20 European restoration projects: Journal of Applied Ecology, v. 52, p. 1518-1527.

Hesselink, A. W., H. J. Weerts, and H. J. Berendsen, 2003. Alluvial architecture of the humaninfluenced river Rhine, The Netherlands: Sedimentary Geology, v. 161, p. 229-248.

Hickin, E. J., 1974. The development of meanders in natural river-channels: American journal of science, v. 274, p. 414-442.

Hickin, E. J., and G. C. Nanson, 1975. The character of channel migration on the Beatton River, northeast British Columbia, Canada: Geological Society of America Bulletin, v. 86 , p. 487-494.

Hickin, E. J., 1978. Mean flow structure in meanders of the Squamish River, British Columbia: Canadian Journal of Earth Sciences, v. 15, p. 1833-1849.

Hickin, E. J., 1979. Concave-bank benches on the Squamish River, British Columbia, Canada: Canadian Journal of Earth Sciences, v. 16, p. 200-203.

Hickin, E. J., 1984. Vegetation and river channel dynamics: The Canadian Geographer/Le Géographe canadien, v. 28, p. 111-126.

Hickin, E. J., and G. C. Nanson, 1984. Lateral migration rates of river bends: Journal of Hydraulic Engineering, v. 110, p. 1557-1567.

Hickin, E. J., 1986. Concave-bank benches in the floodplains of Muskwa and Fort Nelson Rivers, British Columbia: The Canadian Geographer/Le Géographe canadien, v. 30, p. 111-122.

Hjulstrom, F., 1935. Studies of the morphological activity of rivers as illustrated by the river fyris, bulletin: Geological Institute Upsalsa, v. 25, p. 221-527.

Hobo, N., B. Makaske, J. Wallinga, and H. Middelkoop, 2014. Reconstruction of eroded and deposited sediment volumes of the embanked River Waal, the Netherlands, for the period ad 1631-present: Earth Surface Processes and Landforms, v. 39, p. 1301-1318.

Hobo, N., 2015. The sedimentary dynamics in natural and human-influenced delta channel belts, Utrecht, $200 \mathrm{p}$.

Hodskinson, A., and R. Ferguson, 1998. Numerical modelling of separated flow in river bends: Model testing and experimental investigation of geometric controls on the extent of flow separation at the concave bank: Hydrological Processes, v. 12, p. 1323-1338.

Hoek, W. Z., 2008. The last glacial-interglacial transition: Episodes, v. 31, p. 226-229. 
Hoffmann, T., A. Lang, and R. Dikau, 2008. Holocene river activity: analysing 14C-dated fluvial and colluvial sediments from Germany: Quaternary Science Reviews, v. 27, p. 2031-2040. http://dx.doi.org/10.1016/j.quascirev.2008.06.014

Holbrook, J., and S. A. Schumm, 1999. Geomorphic and sedimentary response of rivers to tectonic deformation: a brief review and critique of a tool for recognizing subtle epeirogenic deformation in modern and ancient settings: Tectonophysics, v. 305, p. 287-306.

Holden, J., P. Chapman, and J. Labadz, 2004. Artificial drainage of peatlands: hydrological and hydrochemical process and wetland restoration: Progress in Physical Geography, v. 28, p. 95-123.

Holden, J., M. Evans, T. Burt, and M. Horton, 2006. Impact of land drainage on peatland hydrology: Journal of Environmental Quality, v. 35, p. 1764-1778.

Hooke, J., 2007. Spatial variability, mechanisms and propagation of change in an active meandering river: Geomorphology, v. 84, p. 277-296.

Hooke, J. M., 1980. Magnitude and distribution of rates of river bank erosion: Earth Surface Processes and Landforms, v. 5, p. 143-157.

Hooke, J. M., and L. Yorke, 2010. Rates, distributions and mechanisms of change in meander morphology over decadal timescales, River Dane, UK: Earth Surface Processes and Landforms, v. 35, p. 1601-1614.

Hudson, P. F., and R. H. Kesel, 2000. Channel migration and meander-bend curvature in the lower Mississippi River prior to major human modification: Geology, v. 28, p. 531-534.

Huijzer, B., and J. Vandenberghe, 1998. Climatic reconstruction of the Weichselian Pleniglacial in northwestern and central Europe: Journal of Quaternary Science: Published for the Quaternary Research Association, v. 13, p. 391-417.

Huisink, M., 2000. Changing river styles in response to Weichselian climate changes in the Vecht valley, eastern Netherlands: Sedimentary Geology, v. 133, p. 115-134. http:// dx.doi.org/10.1016/S0037-0738(00)00030-0

Hulscher, S., R. Schielen, D. Augustijn, J. Warmink, M. Voort, H. Middelkoop, M. Kleinhans, R. Leuven, H. Lenders, and A. Smits, 2014, RiverCare: towards self-sustaining multifunctional rivers: Netherlands Centre for River Studies Conference, p. 13-14.

Ikeda, S., and G. Parker, 1989. River meandering: Water Resources Monograph v. 12, American Geophysical Union, 485 p.

Ingram, H., and A. Gore, 1983. Mires: Swamp, bog, fen, and moor, Elsevier Science, Amsterdam, The Netherlands, p. 67-150.

Jager, S., 2015, Van hunebedbouwer tot Drent - Bewaoning en landgebruik tot de Vroege Middeleeuwen, Landschapsbiografie van de Drentsche Aa: Assen, Koninklijke Van Gorcum, p. 54-81.

Janssen, C. R., 1972. The Palaeoecology of Plant Communities in the Dommel Valley, North Brabant, Netherlands: Journal of Ecology, v. 60, p. 411-437. 10.2307/2258354 
Janssens, M. M., C. Kasse, S. J. P. Bohncke, H. Greaves, n. K.M. Cohen, J. Wallinga, and W. Z. Hoek, 2012. Climate-driven fluvial development and valley abandonment at the last glacial-interglacial transition (Oude IJssel-Rhine, Germany): Netherlands Journal of Geosciences, v. 91, p. 37-62. doi:10.1017/S001677460000055X

Jerolmack, D. J., and D. Mohrig, 2007. Conditions for branching in depositional rivers: Geology, v. 35, p. 463-466.

Jongmans, A., M. Van den Berg, and M. Sonneveld, 2012. Landschappen van Nederland: geologie, bodem en landgebruik, Wageningen Academic Publishers.

Julian, J. P., and R. Torres, 2006. Hydraulic erosion of cohesive riverbanks: Geomorphology, v. 76, p. 193-206.

Jurmu, M. C., and R. Andrle, 1997. Morphology of a wetland stream: Environmental management, v. 21, p. 921-941.

Jurmu, M. C., 2002. A morphological comparison of narrow, low-gradient streams traversing wetland environments to alluvial streams: Environmental management, v. 30, p. 0831-0856.

Juyal, N., L. S. Chamyal, S. Bhandari, R. Bhushan, and A. K. Singhvi, 2006. Continental record of the southwest monsoon during the last 130ka: evidence from the southern margin of the Thar Desert, India: Quaternary Science Reviews, v. 25, p. 2632-2650. https://doi.org/10.1016/j.quascirev.2005.07.020

Kaandorp, V., P. De Louw, Y. van der Velde, and H. Broers, 2018. Transient Groundwater Travel Time Distributions and Age-Ranked Storage-Discharge Relationships of Three Lowland Catchments: Water Resources Research, v. 54, p. 4519-4536.

Kaandorp, V. P., P. J. Doornenbal, H. Kooi, H. P. Broers, and P. G. de Louw, 2019. Temperature buffering by groundwater in ecologically valuable lowland streams under current and future climate conditions: Journal of Hydrology, v. 3, p. 100031.

Kail, J., K. Brabec, M. Poppe, and K. Januschke, 2015. The effect of river restoration on fish, macroinvertebrates and aquatic macrophytes: A meta-analysis: Ecological Indicators, v. 58, p. 311-321. http://dx.doi.org/10.1016/j.ecolind.2015.06.011

Kasse, C., W. Z. Hoek, S. J. P. Bohncke, M. Konert, J. W. H. Weijers, M. L. Cassee, and R. M. Van Der Zee, 2005. Late Glacial fluvial response of the Niers-Rhine (western Germany) to climate and vegetation change: Journal of Quaternary Science, v. 20, p. 377-394. 10.1002/jqs.923

Kasse, C., R. Van Balen, S. Bohncke, J. Wallinga, and M. Vreugdenhil, 2016. Climate and base-level controlled fluvial system change and incision during the last glacial-interglacial transition, Roer river, The Netherlands-western Germany: Netherlands Journal of Geosciences, v. 96, p. 71-92.

Kellerhals, R., 1972. Hydraulic and geomorphic characteristics of rivers in Alberta: Alberta Cooperative Research Program in Highway and River Engineering.

Kleinhans, M. G., F. Schuurman, W. Bakx, and H. Markies, 2009. Meandering channel dynamics in highly cohesive sediment on an intertidal mud flat in the Westerschelde estuary, the Netherlands: Geomorphology, v. 105, p. 261-276. 
Kleinhans, M. G., 2010. Sorting out river channel patterns: Progress in Physical Geography, v. 34, p. 287-326.

Kleinhans, M. G., and J. H. Van den Berg, 2011. River channel and bar patterns explained and predicted by an empirical and a physics-based method: Earth Surface Processes and Landforms, v. 36, p. 721-738.

Kleinhans, M. G., B. de Vries, L. Braat, and M. van Oorschot, 2018. Living landscapes: muddy and vegetated floodplain effects on fluvial pattern in an incised river: Earth Surface Processes and Landforms, v. 43, p. 2948-2963.

Kleinhans, M. G., B. Vermeulen, J. L. Best, J. H. J. Candel, A. J. F. Hoitink, and B. Van Prooijen, in review. Cutting Corners: Causes, Mechanisms and Large-Scale Effects of Sharp Bends in Rivers, Estuaries and Deltas: Journal of Geophysical Research: Earth Surface.

Knighton, D., 1984. Fluvial forms and process: Edward Arnold Ltd., London, Great Britain, p. 218.

Kondolf, G. M., H. Piégay, and N. Landon, 2002. Channel response to increased and decreased bedload supply from land use change: contrasts between two catchments: Geomorphology, v. 45, p. 35-51. http://dx.doi.org/10.1016/S0169-555X(01)00188-X

Kondolf, G. M., H. Piégay, L. Schmitt, and D. R. Montgomery, 2003a. Geomorphic classification of rivers and streams: Tools in fluvial geomorphology, p. 133-158.

Kondolf, G. M., H. Piégay, and D. Sear, 2003b. Integrating geomorphological tools in ecological and management studies: Tools in Fluvial Geomorphology, p. 633-660.

Kondolf, G. M., 2006. River restoration and meanders: Ecology and Society, v. 11, p. 42.

Koopman, K. R., M. W. Straatsma, D. C. M. Augustijn, A. M. Breure, H. J. R. Lenders, S. J. Stax, and R. S. E. W. Leuven, 2018. Quantifying biomass production for assessing ecosystem services of riverine landscapes: Science of The Total Environment, v. 624, p. 1577-1585. https://doi.org/10.1016/j.scitotenv.2017.12.044

Koster, E. A., I. I. Castel, and R. L. Nap, 1993. Genesis and sedimentary structures of late Holocene aeolian drift sands in northwest Europe: Geological Society, London, Special Publications, v. 72, p. 247-267.

Kuenen, P. H., 1944. The Drentse riviertjes en het meander-vraagstuk: Overdruk uit Gedenkboek P. Tesch.

Labbe, J. M., K. S. Hadley, A. M. Schipper, R. S. Leuven, and C. P. Gardiner, 2011. Influence of bank materials, bed sediment, and riparian vegetation on channel form along a gravelto-sand transition reach of the Upper Tualatin River, Oregon, USA: Geomorphology, v. 125, p. 374-382.

Lambeek, J. J. P., and G. J. Klaassen, 1994. Haalbaarheidsstudie referentie-onderzoek Grensmaas: Bureaustudie / Waterloopkundig Laboratorium;Q 1437: [Delft], Waterloopkundig Laboratorium.

Landis, J. R., and G. G. Koch, 1977. The measurement of observer agreement for categorical data: biometrics, p. 159-174. 
Lane, E. W., 1957. A study of the shape of channels formed by natural streams flowing in erodible material: Missouri River, US Army Engineer Division.

Langford, R. P., 1989. Fluvial-aeolian interactions: Part I, modern systems: Sedimentology, v. 36, p. 1023-1035. 10.1111/j.1365-3091.1989.tb01540.x

Langford, R. P., and M. A. Chan, 1989. Fluvial-aeolian interactions: Part II, ancient systems: Sedimentology, v. 36, p. 1037-1051. 10.1111/j.1365-3091.1989.tb01541.x

Lapen, D., B. Moorman, and J. Price, 1996. Using ground-penetrating radar to delineate subsurface features along a wetland catena: Soil Science Society of America Journal, v. 60, p. 923-931.

Latrubesse, E. M., and T. Kalicki, 2002. Late Quaternary palaeohydrological changes in the upper Purus basin, southwestern Amazonia, Brazil: Zeitschrift fur Geomorphologie Supplementband, p. 41-59.

Latrubesse, E. M., 2008. Patterns of anabranching channels: The ultimate end-member adjustment of mega rivers: Geomorphology, v. 101, p. 130-145.

Lazarus, E. D., and J. A. Constantine, 2013. Generic theory for channel sinuosity: Proceedings of the National Academy of Sciences, v. 110, p. 8447-8452.

Leeder, M., 1973. Fluviatile fining-upwards cycles and the magnitude of palaeochannels: Geological Magazine, v. 110, p. 265-276.

Leeder, M., and P. Bridges, 1975. Flow separation in meander bends: Nature, v. 253, p. 338-339.

Lenderink, G., and E. Van Meijgaard, 2008. Nature Geoscience, v. 1, p. 511.

Lenke, W., 1968. Das Klima Ende des 16. und Anfang des 17. Jahrhunderts nach Beobachtungen von Tycho de Brahe auf Hven im Sund DK, Leopold III. Treutwein in Fiirstenfeld Oberbayern und David Fabricius in Ostfriesland: Berichte des Dt. Wetterdienstes, v. 15.

Leopold, L. B., and M. G. Wolman, 1957. River channel patterns: braided, meandering, and straight: USGS Professional Paper, p. 39-86.

Leopold, L. B., and M. G. Wolman, 1960. River meanders: Geological Society of America Bulletin, v. 71, p. 769-793.

Lespez, L., V. Viel, A. Rollet, and D. Delahaye, 2015. The anthropogenic nature of presentday low energy rivers in western France and implications for current restoration projects: Geomorphology, v. 251, p. 64-76.

Lewin, J., B. Davies, and P. Wolfenden, 1977. Interactions between channel change and historic mining sediments, New York, Wiley, p. 353-367.

Lewin, J., M. G. Macklin, and E. Johnstone, 2005. Interpreting alluvial archives: sedimentological factors in the British Holocene fluvial record: Quaternary Science Reviews, v. 24, p. 1873-1889. http://dx.doi.org/10.1016/j.quascirev.2005.01.009

Lewin, J., and M. G. Macklin, 2010. Floodplain catastrophes in the UK Holocene: messages for managing climate change: Hydrological Processes, v. 24, p. 2900-2911. 10.1002/ hyp.7704 
Li, C., M. J. Czapiga, E. C. Eke, E. Viparelli, and G. Parker, 2015. Variable Shields number model for river bankfull geometry: bankfull shear velocity is viscosity-dependent but grain size-independent: Journal of Hydraulic Research, v. 53, p. 36-48.

Liébault, F., and H. Piégay, 2001. Assessment of channel changes due to long-term bedload supply decrease, Roubion River, France: Geomorphology, v. 36, p. 167-186. http:// dx.doi.org/10.1016/S0169-555X(00)00044-1

Lobeck, A. K., 1939. Geomorphology, an introduction to the study of landscapes.

Lorenz, A., S. Jähnig, and D. Hering, 2009. Re-Meandering German Lowland Streams: Qualitative and Quantitative Effects of Restoration Measures on Hydromorphology and Macroinvertebrates: Environmental Management, v. 44, p. 745-754. 10.1007/s00267009-9350-4

Lowry, C. S., D. Fratta, and M. P. Anderson, 2009. Ground penetrating radar and spring formation in a groundwater dominated peat wetland: Journal of Hydrology, v. 373, p. 68-79.

Maas, G., 1995, De Overijsselse Vecht - Geomorfogenetische gesteldheid anno 1890: DLO - Staring Centrum Wageningen.

Maaß,A.-L., and H.Schüttrumpf, 2019. Elevated floodplains and net channel incision as a result of the construction and removal of water mills, 1-20 p. 10.1080/04353676.2019.1574209

MacDonald, T. E., G. Parker, and D. P. Luethe, 1991. Inventory and analysis of stream meander problems in Minnesota, St. Anthony Falls Hydraulic Laboratory.

Macklin, M. G., A. F. Jones, and J. Lewin, 2010. River response to rapid Holocene environmental change: evidence and explanation in British catchments: Quaternary Science Reviews, v. 29, p. 1555-1576. http://dx.doi.org/10.1016/j.quascirev.2009.06.010

Mactaggart, B., J. Bauer, D. Goldney, and A. Rawson, 2008. Problems in naming and defining the swampy meadow-an Australian perspective: Journal of environmental management, v. 87, p. 461-473.

Madsen, A. T., A. Murray, T. Andersen, M. Pejrup, and H. Breuning-Madsen, 2005. Optically stimulated luminescence dating of young estuarine sediments: a comparison with $210 \mathrm{~Pb}$ and 137 Cs dating: Marine Geology, v. 214, p. 251-268.

Maharana, C., D. Srivastava, and J. K. Tripathi, 2018. Geochemistry of sediments of the Peninsular rivers of the Ganga basin and its implication to weathering, sedimentary processes and provenance: Chemical Geology, v. 483, p. 1-20. https://doi.org/10.1016/j. chemgeo.2018.02.019

Makaske, B., 1998. Anastomosing rivers: forms, processes and sediments, Koninklijk Nederlands Aardrijkskundig Genootschap.

Makaske, B., 2001. Anastomosing rivers: a review of their classification, origin and sedimentary products: Earth-Science Reviews, v. 53, p. 149-196.

Makaske, B., D. G. Smith, and H. J. Berendsen, 2002. Avulsions, channel evolution and floodplain sedimentation rates of the anastomosing upper Columbia River, British Columbia, Canada: Sedimentology, v. 49, p. 1049-1071. 
Makaske, B., and H. J. Weerts, 2005. Muddy lateral accretion and low stream power in a subrecent confined channel belt, Rhine-Meuse delta, central Netherlands: Sedimentology, v. 52, p. 651-668.

Makaske, B., D. G. Smith, H. J. A. Berendsen, A. G. de Boer, M. F. van Nielen-Kiezebrink, and T. Locking, 2009. Hydraulic and sedimentary processes causing anastomosing morphology of the upper Columbia River, British Columbia, Canada: Geomorphology, v. 111, p. 194-205. http://dx.doi.org/10.1016/j.geomorph.2009.04.019

Makaske, B., and G. Maas, 2015. Handboek geomorfologisch beekherstel: leidraad voor een stapsgewijze en integrale ontwerpaanpak., v. 2015-02: Amersfoort, Stichting Toegepast Onderzoek Waterbeheer.

Makaske, B., G. Maas, A. Grootjans, E. Meijles, H. Everts, and N. De Vries, 2015, Veen verschijnt en verdwijnt - Grondwaterstromen en veenvorming, Landschapsbiografie van de Drentsche Aa: Assen, Koninklijke Van Gorcum, p. 54-81.

Makaske, B., E. van der Deijl, and M. Kleinhans, 2016. Het natuurlijke patroon van beken: Landschap, v. 33, p. 185-193.

Manley, G., 1969. Snowfall in Britain over the past 300 years: Weather, v. 24, p. 428-437.

Mason, J., and D. Mohrig, 2019. Scroll bars are inner bank levees along meandering river bends: Earth Surface Processes and Landforms. 10.1002/esp.4690

Mayewski, P. A., E. E. Rohling, J. C. Stager, W. Karlén, K. A. Maasch, L. D. Meeker, E. A. Meyerson, F. Gasse, S. van Kreveld, and K. Holmgren, 2004. Holocene climate variability: Quaternary research, v. 62, p. 243-255.

McMillan, S. K., and P. G. Vidon, 2014. Taking the pulse of stream restoration practices: moving towards healthier streams: Hydrological Processes, v. 28, p. 398-400. 10.1002/ hyp. 10092

Meijles, E., 2015, Waterafvoer in de 20ste eeuw, Landschapsbiografie van de Drentsche Aa: Assen, Koninklijke Van Gorcum, p. 54-81.

Mejdahl, V., 1979. Thermoluminescence dating: beta-dose attenuation in quartz grains: Archaeometry, v. 21, p. 61-72.

Menting, F., and E. W. Meijles, 2019. Local Factors Determining Spatially Heterogeneous Channel Migration in a Low-Energy Stream: Water, v. 11, p. 2149.

Miall, A. D., 2014. Fluvial depositional systems, Springer, 316 pp.

Micheli, E., and J. Kirchner, 2002a. Effects of wet meadow riparian vegetation on streambank erosion. 1. Remote sensing measurements of streambank migration and erodibility: Earth Surface Processes and Landforms, v. 27, p. 627-639.

Micheli, E., and J. Kirchner, 2002b. Effects of wet meadow riparian vegetation on streambank erosion. 2. Measurements of vegetated bank strength and consequences for failure mechanics: Earth Surface Processes and Landforms, v. 27, p. 687-697.

Millar, R. G., 2000. Influence of bank vegetation on alluvial channel patterns: Water Resources Research, v. 36, p. 1109-1118. 
Mitchener, H., and H. Torfs, 1996. Erosion of mud/sand mixtures: Coastal engineering, v. 29 , p. 1-25.

Mol, J., J. Vandenberghe, and C. Kasse, 2000. River response to variations of periglacial climate in mid-latitude Europe: Geomorphology, v. 33, p. 131-148. http://dx.doi. org/10.1016/S0169-555X(99)00126-9

Mook, W., and H. Streurman, 1983, Physical and chemical aspects of radiocarbon dating: Proceedings of the First International Symposium $14 \mathrm{C}$ and Archaeology, Groningen, 1981, p. 31-55.

Morris, M. R., and J. A. Stanford, 2011. Floodplain succession and soil nitrogen accumulation on a salmon river in southwestern Kamchatka: Ecological Monographs, v. 81, p. 43-61.

Morton, R. A., and A. C. Donaldson, 1977. The Guadalupe River and delta of Texas-A modern analogue for some ancient fluvial-deltaic systems: Fluvial Sedimentology, p. 773-787.

Morton, R. A., and A. C. Donaldson, 1978. Hydrology, morphology, and sedimentology of the Guadalupe fluvial-deltaic system: Geological Society of America Bulletin, v. 89, p. 1030-1036.

Motta, D., J. D. Abad, E. J. Langendoen, and M. H. Garcia, 2011, Floodplain heterogeneity and meander migration: Proceedings of the $7 \mathrm{P}$ th P Symposium on River, Coastal, and Estuarine Morphodynamics, Beijing, China.

Motta, D., J. D. Abad, E. J. Langendoen, and M. H. Garcia, 2012a. The effects of floodplain soil heterogeneity on meander planform shape: Water Resources Research, v. 48.

Motta, D., J. D. Abad, E. J. Langendoen, and M. H. Garcia, 2012b. A simplified 2D model for meander migration with physically-based bank evolution: Geomorphology, v. 163, p. 10-25.

Moulin, B., E. R. Schenk, and C. R. Hupp, 2011. Distribution and characterization of in-channel large wood in relation to geomorphic patterns on a low-gradient river: Earth Surface Processes and Landforms, v. 36, p. 1137-1151.

Mudelsee, M., M. Börngen, G. Tetzlaff, and U. Grünewald, 2003. No upward trends in the occurrence of extreme floods in central Europe: Nature, v. 425, p. 166-169.

Mudelsee, M., M. Börngen, G. Tetzlaff, and U. Grünewald, 2004. Extreme floods in central Europe over the past 500 years: Role of cyclone pathway "Zugstrasse Vb": Journal of Geophysical Research: Atmospheres, v. 109. doi:10.1029/2004JD005034

Murray, A. B., and C. Paola, 2003. Modelling the effect of vegetation on channel pattern in bedload rivers: Earth Surface Processes and Landforms: The Journal of the British Geomorphological Research Group, v. 28, p. 131-143.

Murray, A. S., and A. G. Wintle, 2003. The single aliquot regenerative dose protocol: potential for improvements in reliability: Radiation measurements, v. 37, p. 377-381.

Nanson, G. C., 1980. Point bar and floodplain formation of the meandering Beatton River, northeastern British Columbia, Canada: Sedimentology, v. 27, p. 3-29.

Nanson, G. C., and E. J. Hickin, 1986. A statistical analysis of bank erosion and channel migration in western Canada: Geological Society of America Bulletin, v. 97, p. 497-504.

Nanson, G. C., and J. C. Croke, 1992. A genetic classification of floodplains: Geomorphology, v. 4, p. 459-486. http://dx.doi.org/10.1016/0169-555X(92)90039-Q 
Nanson, G. C., and A. D. Knighton, 1996. Anabranching rivers: their cause, character and classification: Earth surface processes and landforms, v. 21, p. 217-239.

Nanson, R. A., 2009. The Evolution of Peat-Swamp Channels and Organic Floodplains, Barrington Tops, New South Wales, Australia: Geographical Research, v. 47, p. 434-448. 10.1111/j.1745-5871.2009.00596.x

Nanson, R. A., 2010. Flow fields in tightly curving meander bends of low width-depth ratio: Earth Surface Processes and Landforms, v. 35, p. 119-135.

Nanson, R. A., G. C. Nanson, and H. Q. Huang, 2010. The hydraulic geometry of narrow and deep channels; evidence for flow optimisation and controlled peatland growth: Geomorphology, v. 117, p. 143-154. http://dx.doi.org/10.1016/j.geomorph.2009.11.021

Nanson, R. A., and T. J. Cohen, 2014. Headwater peatland channels in south-eastern Australia; the attainment of equilibrium: Geomorphology, v. 212, p. 72-83. http:// dx.doi.org/10.1016/j.geomorph.2013.11.011

Neal, A., 2004. Ground-penetrating radar and its use in sedimentology: principles, problems and progress: Earth-Science Reviews, v. 66, p. 261-330. http://dx.doi.org/10.1016/j. earscirev.2004.01.004

Neefjes, J., O. Brinkkemper, L. Jehee, and W. Van de Griendt, 2011. Cultuur-historische atlas van de Vecht: WBooks, Zwolle.

Newson, M. D., and A. R. G. Large, 2006. 'Natural' rivers, 'hydromorphological quality' and river restoration: a challenging new agenda for applied fluvial geomorphology: Earth Surface Processes and Landforms, v. 31, p. 1606-1624. 10.1002/esp.1430

Nicoll, T. J., and E. J. Hickin, 2010. Planform geometry and channel migration of confined meandering rivers on the Canadian prairies: Geomorphology, v. 116, p. 37-47.

Nimmo, J., 2004, Porosity and pore size distribution, in D. Hillel, ed., Encyclopedia of Soils in the Environment, v. 3: Amsterdam, Elsevier, p. 295-303.

Notebaert, B., and G. Verstraeten, 2010. Sensitivity of West and Central European river systems to environmental changes during the Holocene: A review: Earth-Science Reviews, v. 103, p. 163-182. http://dx.doi.org/10.1016/j.earscirev.2010.09.009

Notebaert, B., N. Broothaerts, and G. Verstraeten, 2018. Evidences of anthropogenic tipping points in fluvial dynamics in Europe: Global and Planetary Change, v. 164, p. 27-38.

Osborn, G., and C. du Toit, 1991. Lateral planation of rivers as a geomorphic agent: Geomorphology, v. 4, p. 249-260. https://doi.org/10.1016/0169-555X(91)90008-X

Osterkamp, W. R., and E. Hedman, 1982. Perennial-streamflow characteristics related to channel geometry and sediment in Missouri River basin, p. 37. 10.3133/pp1242

Page, K., and G. Nanson, 1982. Concave-bank benches and associated floodplain formation: Earth Surface Processes and Landforms, v. 7, p. 529-543.

Page, K., G. Nanson, and P. Frazier, 2003. Floodplain formation and sediment stratigraphy resulting from oblique accretion on the Murrumbidgee River, Australia: Journal of Sedimentary Research, v. 73, p. 5-14. 
Page, S. E., J. Rieley, Ø. Shotyk, and D. Weiss, 1999. Interdependence of peat and vegetation in a tropical peat swamp forest: Philosophical Transactions of the Royal Society of London B: Biological Sciences, v. 354, p. 1885-1897.

Papanicolaou, A. N., 2001. Erosion of cohesive streambeds and banks: Report WRR-08, State of Washington Water Research Center. Washington State Univ, Pullman.

Parker, G., 1976. On the cause and characteristic scales of meandering and braiding in rivers: Journal of fluid mechanics, v. 76, p. 457-480.

Parker, G., 2008, Transport of gravel and sediment mixtures, in M. H. Garcia, ed., Sedimentation Engineering: Processes, Measurements, Modeling and Practice, ASCE Manual and Reports on Engineering Practice, v. 110: New York, Am. Soc. of Civ. Eng., p. 165-252.

Passmore, D. G., M. G. Macklin, P. A. Brewer, J. Lewin, B. T. Rumsby, and M. D. Newson, 1993. Variability of late Holocene braiding in Britain: Geological Society, London, Special Publications, v. 75, p. 205-229.

Pasternack, G., 2013, Geomorphologist's guide to participating in river rehabilitation, Treatise on Geomorphology, v. 9, p. 843-860.

Peakall, J., P. J. Ashworth, and J. L. Best, 2007. Meander-bend evolution, alluvial architecture, and the role of cohesion in sinuous river channels: a flume study: Journal of Sedimentary Research, v. 77, p. 197-212.

Pedersen, M. L., K. K. Kristensen, and N. Friberg, 2014. Re-meandering of lowland streams: will disobeying the laws of geomorphology have ecological consequences?: PloS one, v. 9, p. e108558.

Peeters, J., F. S. Busschers, and E. Stouthamer, 2015. Fluvial evolution of the Rhine during the last interglacial-glacial cycle in the southern North Sea basin: a review and look forward: Quaternary international, v. 357, p. 176-188.

Peeters, J., F. Busschers, E. Stouthamer, J. Bosch, M. Van den Berg, J. Wallinga, A. Versendaal, F. Bunnik, and H. Middelkoop, 2016. Sedimentary architecture and chronostratigraphy of a late Quaternary incised-valley fill: A case study of the late Middle and Late Pleistocene Rhine system in the Netherlands: Quaternary Science Reviews, v. 131, p. 211-236.

Petts, G. E., and I. D. Foster, 1985. Rivers and landscape, Edward Arnold.

Petts, G. E., 2018, Perspectives for ecological management of regulated rivers, Alternatives in regulated river management, CRC press, p. 3-24.

Pfister, L., J. Kwadijk, A. Musy, A. Bronstert, and L. Hoffmann, 2004. Climate change, land use change and runoff prediction in the Rhine-Meuse basins: River research and applications, v. 20, p. 229-241.

Pierik, H. J., 2017. Past human-landscape interactions in the Netherlands: Reconstructions from sand belt to coastal-delta plain for the first millennium AD, Utrecht University.

Pîrnău, R. G., A. Mihu-Pintilie, G. Bodi, A. Asăndulesei, and L. Niacșu, 2015. Ground penetrating radar as non-invasive method used in soil science and archaelogy,: Soil Forming Factors and Processes from the Temperate Zone, v. 13, p. 15-32. 
Pizzuto, J. E., 1984. Bank erodibility of shallow sandbed streams: Earth Surface Processes and Landforms, v. 9, p. 113-124.

Pollen, N., 2007. Temporal and spatial variability in root reinforcement of streambanks: Accounting for soil shear strength and moisture: CATENA, v. 69, p. 197-205. https:// doi.org/10.1016/j.catena.2006.05.004

Polvi, L. E., E. Wohl, and D. M. Merritt, 2014. Modeling the functional influence of vegetation type on streambank cohesion: Earth Surface Processes and Landforms, v. 39, p. $1245-1258$.

Poppe, M., J. Kail, J. Aroviita, M. Stelmaszczyk, M. Giełczewski, and S. Muhar, 2015. Assessing restoration effects on hydromorphology in European mid-sized rivers by key hydromorphological parameters: Hydrobiologia, p. 1-20. 10.1007/s10750-015-2468-x

Prescott, J. R., and J. T. Hutton, 1994. Cosmic ray contributions to dose rates for luminescence and ESR dating: large depths and long-term time variations: Radiation measurements, v. 23, p. 497-500.

Preti, F., A. Dani, and F. Laio, 2010. Root profile assessment by means of hydrological, pedological and above-ground vegetation information for bio-engineering purposes: Ecological Engineering, v. 36, p. 305-316. https://doi.org/10.1016/j.ecoleng.2009.07.010

Preusser, F., D. Degering, M. Fuchs, A. Hilgers, A. Kadereit, N. Klasen, M. Krbetschek, D. Richter, and J. Q. Spencer, 2008. Luminescence dating: basics, methods and applications: Quaternary Science Journal, v. 57, p. 95-149.

Prosser, I. P., J. Chappell, and R. Gillespie, 1994. Holocene valley aggradation and gully erosion in headwater catchments, south-eastern highlands of Australia: Earth Surface Processes and Landforms, v. 19, p. 465-480. 10.1002/esp.3290190507

Proulx-McInnis, S., A. St-Hilaire, A. N. Rousseau, and S. Jutras, 2013. A review of groundpenetrating radar studies related to peatland stratigraphy with a case study on the determination of peat thickness in a northern boreal fen in Quebec, Canada: Progress in Physical Geography, v. 37, p. 767-786. 10.1177/0309133313501106

Quesada, B., R. Vautard, P. Yiou, M. Hirschi, and S. I. Seneviratne, 2012. Asymmetric European summer heat predictability from wet and dry southern winters and springs: Nature Climate Change, v. 2, p. 736.

Quik, C., and J. Wallinga, 2018. Reconstructing lateral migration rates in meandering systems; combining OSL dating with historical maps.: Earth Surf. Dynam. https://doi. org/10.5194/esurf-2018-30

Rajchl, M., and D. Uličný, 2005. Depositional record of an avulsive fluvial system controlled by peat compaction (Neogene, Most Basin, Czech Republic): Sedimentology, v. 52, p. 601-625. 10.1111/j.1365-3091.2005.00691.x

Rannie, W.F., 1990, The Portage La Prairie "Floodplain Fan," in Rachocki, A.H., and Church, M., eds., Alluvial Fans: A Field Approach: New York, John Wiley \& Sons, p. 179-193.

Reimer, P. J., M. G. Baillie, E. Bard, A. Bayliss, J. W. Beck, P. G. Blackwell, R. C. Bronk, C. E. Buck, G. S. Burr, and R. L. Edwards, 2009. IntCal09 and Marine09 radiocarbon age calibration curves, 0-50,000 years cal BP: Radiocarbon, v. 51, p. 1111-1150. 
Reimer, P. J., E. Bard, A. Bayliss, J. W. Beck, P. G. Blackwell, C. Bronk Ramsey, C. E. Buck, H. Cheng, R. L. Edwards, and M. Friedrich, 2013. IntCal13 and Marine13 radiocarbon age calibration curves 0-50,000 years cal BP: Radiocarbon, v. 51, p. 1111-1150.

Richards, K., J. Brasington, and F. Hughes, 2002. Geomorphic dynamics of floodplains: ecological implications and a potential modelling strategy: Freshwater Biology, v. 47, p. 559-579.

Rodnight, H., G. Duller, S. Tooth, and A. Wintle, 2005. Optical dating of a scroll-bar sequence on the Klip River, South Africa, to derive the lateral migration rate of a meander bend: The Holocene, v. 15, p. 802-811.

Rosgen, D. L., 1994. A classification of natural rivers: Catena, v. 22, p. 169-199.

Rumsby, B. T., and M. G. Macklin, 1996. River response to the last neoglacial (the 'Little Ice Age') in northern, western and central Europe: Geological Society, London, Special Publications, v. 115, p. 217-233.

Rust, B. R., 1978, A classification of alluvial channel systems, in A. D. Miall, ed., Fluvial Sedimentology. Canadian Society of Petroleum Geologists Memoir 5: Calgary, p. 187-198.

Sahu, S., and D. Saha, 2014. Geomorphologic, stratigraphic and sedimentologic evidences of tectonic activity in Sone-Ganga alluvial tract in Middle Ganga Plain, India: Journal of earth system science, v. 123, p. 1335-1347.

Schokker, J., 2003. Patterns and processes in a Pleistocene fluvio-aeolian environment, Utrecht University, Utrecht.

Schokker, J., and E. A. Koster, 2004. Sedimentology and facies distribution of Pleistocene cold-climate aeolian and fluvial deposits in the Roer Valley Graben (southeastern Netherlands): Permafrost and periglacial processes, v. 15, p. 1-20.

Schumm, S. A., 1960. The shape of alluvial channels in relation to sediment type: US Geol. Survey Prof Paper., B, v. 352, p. 17-30.

Schumm, S. A., 1963. Sinuosity of alluvial rivers on the Great Plains: Geological Society of America Bulletin, v. 74, p. 1089-1100.

Schumm, S. A., 1968. River adjustment to altered hydrologic regimen, Murrumbidgee River and paleochannels, Australia, v. 598, US Government Printing Office.

Schumm, S. A., J. F. Dumont, and J. M. Holbrook, 2002. Active tectonics and alluvial rivers: Cambridge, UK, Cambridge University Press.

Sear, D. A., and N. W. Arnell, 2006. The application of palaeohydrology in river management: CATENA, v. 66, p. 169-183. http://dx.doi.org/10.1016/j.catena.2005.11.009

Sedell, J. R., G. H. Reeves, F. R. Hauer, J. A. Stanford, and C. P. Hawkins, 1990. Role of refugia in recovery from disturbances: modern fragmented and disconnected river systems: Environmental Management, v. 14, p. 711-724.

Seminara, G., and M. Tubino, 1989. Alternate bars and meandering: free, forced and mixed interactions: River meandering, v. 12, p. 267-320.

Seminara, G., 2006. Meanders: Journal of fluid mechanics, v. 554, p. 271-297. 
Sevink, J., E. A. Koster, B. van Geel, and J. Wallinga, 2013. Drift sands, lakes, and soils: the multiphase Holocene history of the Laarder Wasmeren area near Hilversum, the Netherlands: Netherlands Journal of Geosciences, v. 92, p. 243-266. doi:10.1017/ S0016774600000196

Shields, A., 1936. Application of similarity principles and turbulence research to bed-load movement.

Silver, M., and C. R. Griffin, 2009. Nesting habitat characteristics of bank swallows and belted kingfishers on the Connecticut River: Northeastern Naturalist, v. 16, p. 519-535.

Simon, A., A. J. Collison, and A. Layzell, 2003, Incorporating bank-toe erosion by hydraulic shear into the ARS bank-stability model: Missouri River, Eastern Montana: World Water \& Environmental Resources Congress 2003, p. 1-11.

Simon, A., M. Doyle, M. Kondolf, F. D. Shields, B. Rhoads, and M. McPhillips, 2007. Critical Evaluation of How the Rosgen Classification and Associated "Natural Channel Design" Methods Fail to Integrate and Quantify Fluvial Processes and Channel Response1, Wiley Online Library.

Simpson, C. J., and D. G. Smith, 2001. The braided Milk River, northern Montana, fails the Leopold-Wolman discharge-gradient test: Geomorphology, v. 41, p. 337-353.

Singh, M., I. B. Singh, and G. Müller, 2007. Sediment characteristics and transportation dynamics of the Ganga River: Geomorphology, v. 86, p. 144-175. https://doi. org/10.1016/j.geomorph.2006.08.011

Słowik, M., 2013. Transformation of a lowland river from a meandering and multi-channel pattern into an artificial canal: retracing a path of river channel changes (the Middle Obra River, W Poland): Regional Environmental Change, v. 13, p. 1287-1299. 10.1007/ s10113-013-0453-3

Słowik, M., 2015. Is history of rivers important in restoration projects? The example of human impact on a lowland river valley (the Obra River, Poland): Geomorphology, v. 251, p. 50-63. http://dx.doi.org/10.1016/j.geomorph.2015.05.031

Smith, D. G., S. M. Hubbard, D. A. Leckie, and M. Fustic, 2009. Counter point bar deposits: lithofacies and reservoir significance in the meandering modern Peace River and ancient McMurray Formation, Alberta, Canada: Sedimentology, v. 56, p. 1655-1669.

Smith, D. G., S. M. Hubbard, J. R. Lavigne, D. A. Leckie, and M. Fustic, 2011. Stratigraphy of counter-point-bar and eddy-accretion deposits in low-energy meander belts of the Peace-Athabasca Delta, northeast Alberta, Canada: From River to Rock Record: The Preservation of Fluvial Sediments and Their Subsequent Interpretation: SEPM, Special Publication, v. 97, p. 143-152.

Soar, P. J., and C. R. Thorne, 2001. Channel restoration design for meandering rivers, Rep. ERDC/CHL CR-01-1, Vicksburg, Miss., Coastal Hydraul. Lab., Eng. Res. and Dev. Cent, U.S. Army Corps of Eng., p. 416.

Soulsby, R., 1997. Dynamics of marine sands: a manual for practical applications, Thomas Telford. 
Spek, T., H. Elerie, J. P. Bakker, and I. Noordhoff, 2015. Landschapsbiografie van de Drentsche Aa: Assen, Koninklijke Van Gorcum.

Staring, W. C. A., and T. J. Stieltjes, 1848. De Overijsselsche wateren: Zwolle, s.n., 488 p.

Stenberg, L., T. Tuukkanen, L. Finér, H. Marttila, S. Piirainen, B. Kløve, and H. Koivusalo, 2015. Evaluation of erosion and surface roughness in peatland forest ditches using pin meter measurements and terrestrial laser scanning: Earth Surface Processes and Landforms, p. 1299-1311. 10.1002/esp.3897

Stølum, H.-H., 1996. River meandering as a self-organization process: Science, v. 271, p. 1710-1713.

Storme, A., J. Bastiaens, P. Crombé, S. Debruyne, S. Louwye, and K. Deforce, 2018. Ecology and fluvial dynamics of an Early Holocene medium-sized European lowland river valley (Upper Scheldt, northern Belgium). 10.1111/bor.12362

Straatsma, M. W., A. M. Bloecker, H. R. Lenders, R. S. Leuven, and M. G. Kleinhans, 2017. Biodiversity recovery following delta-wide measures for flood risk reduction: Science advances, v. 3, p. e1602762.

Streefkerk, J., and W. Casparie, 1987. De hydrologie van hoogveen systemen: Staatsbosbeheerrapport, v. 19, p. 1-119.

Struiksma, N., K. Olesen, C. Flokstra, and H. de Vriend, 1985. Bed deformation in curved alluvial channels: Journal of Hydraulic Research, v. 23, p. 57-79.

Sun, T., P. Meakin, T. Jøssang, and K. Schwarz, 1996. A simulation model for meandering rivers: Water resources research, v. 32, p. 2937-2954.

Surian, N., and M. Rinaldi, 2003. Morphological response to river engineering and management in alluvial channels in Italy: Geomorphology, v. 50, p. 307-326.

Sylvester, Z., J. A. Covault, and P. Durkin, 2019. High curvatures drive river meandering. $10.1130 / \mathrm{g} 45608.1$

Tal, M., and C. Paola, 2010. Effects of vegetation on channel morphodynamics: results and insights from laboratory experiments: Earth Surface Processes and Landforms, v. 35, p. 1014-1028.

Talmon, A., N. Struiksma, and M. Van Mierlo, 1995. Laboratory measurements of the direction of sediment transport on transverse alluvial-bed slopes: Journal of Hydraulic Research, v. 33, p. 495-517.

TAUW, 1992. Bouwstenen voor een natuurontwikkelingsvisie voor de Overijsselse Vecht, Deventer, Directie Natuur, Bos, Landschap en Fauna, nr. 3187381.

Taylor, G., and K. Woodyer, 1977, Bank deposition in suspended-load streams, in A. D. M. E. F. Sedimentology, ed., Canadian Society of Petroleum Geologists, Memoir, v. 5, p. 257-275.

Ter Wee, M., 1966. Toelichtingen bij de geologische kaart van Nederland 1: 50.000: blad Steenwijk oost (16 O), Geologische Stichting.

Thorndycraft, V. R., 2013, Palaeohydrology, In Encyclopedia of Quaternary Science (Second Edition): Amsterdam, Elsevier, p. 253-258. http://dx.doi.org/10.1016/B978-0-44453643-3.00114-X 
Thorne, C., 1982. Processes and mechanisms of river bank erosion: Gravel-bed rivers, p. 227-259.

TNO, 2015. DINOLoket, Online: https://www.dinoloket.nl/ondergrondmodellen.

Toonen, W. H. J., M. G. Kleinhans, and K. M. Cohen, 2012. Sedimentary architecture of abandoned channel fills: Earth Surface Processes and Landforms, v. 37, p. 459-472. 10.1002/esp.3189

Tooth, S., J. D. Jansen, G. C. Nanson, T. J. Coulthard, and T. Pietsch, 2008. Riparian vegetation and the late Holocene development of an anabranching river: Magela Creek, northern Australia: Geological Society of America Bulletin, v. 120, p. 1021-1035.

Törnqvist, T., A. F. de Jong, W. A. Oosterbaan, and K. Van der Borg, 1992. Accurate dating of organic deposits by AMS 14C measurement of macrofossils: Radiocarbon, v. 34, p. 566-577.

Törnqvist, T. E., 1993. Holocene alternation of meandering and anastomosing fluvial systems in the Rhine-Meuse delta (central Netherlands) controlled by sea-level rise and subsoil erodibility: Journal of Sedimentary Research, v. 63, p. 683-693.

Trimble, S. W., and A. C. Mendel, 1995. The cow as a geomorphic agent-a critical review: Geomorphology, v. 13, p. 233-253.

Trinci, G., G. L. Harvey, A. J. Henshaw, W. Bertoldi, and F. Hölker, 2017. Life in turbulent flows: interactions between hydrodynamics and aquatic organisms in rivers: Wiley Interdisciplinary Reviews: Water, v. 4, p. e1213.

Tubino, M., and G. Seminara, 1990. Free-forced interactions in developing meanders and suppression of free bars: Journal of Fluid Mechanics, v. 214, p. 131-159.

Tullos, D., and C. Walter, 2015. Fish use of turbulence around wood in winter: physical experiments on hydraulic variability and habitat selection by juvenile coho salmon, Oncorhynchus kisutch: Environmental Biology of Fishes, v. 98, p. 1339-1353.

Turnbull, W. J., E. L. Krinitzky, and F. J. Weaver, 1966. Bank erosion in soils of the lower Mississippi valley: Journal of the Soil Mechanics and Foundations Division, v. 92, p. 121-136.

Turowski, J. M., N. Hovius, H. Meng-Long, D. Lague, and C. Men-Chiang, 2008. Distribution of erosion across bedrock channels: Earth Surface Processes and Landforms, v. 33, p. 353-363.

Twidale, C. R., 2004. River patterns and their meaning: Earth-Science Reviews, v. 67, p. 159-218. https://doi.org/10.1016/j.earscirev.2004.03.001

Uhden, O., 1967. Niederschlags-und Abflußbeobachtungen auf unberührten, vorentwässerten und kultivierten Teilen eines nordwestdeutschen Hochmoores, der Esterweger Dose am Küstenkanal bei Papenburg, Schriftenreihe Kuratorium f. Kulturbauwesen 15, Hamburg, Verlag Wasser und Boden.

Van Alphen, J., P. Bloks, and P. Hoekstra, 1984. Flow and grainsize pattern in a sharply curved river bend: Earth Surface Processes and Landforms, v. 9, p. 513-522.

Van Balen, R., C. Kasse, and J. De Moor, 2008. Impact of groundwater flow on meandering; example from the Geul River, The Netherlands: Earth Surface Processes and Landforms, v. 33, p. 2010-2028. 
Van Beek, R., and B. Groenewoudt, 2011. An Odyssey along the River Vecht in the Dutch-German border area: A Regional Analysis of Roman-period Sites in Germania Magna: Germania: Anzeiger der Römisch-Germanischen Komission des Deutschen Archäologischen Institute, v. 89, p. 157-190.

Van Beek, R., G. J. Maas, and E. van den Berg, 2015a. Home Turf: an interdisciplinary exploration of the long-term development, use and reclamation of raised bogs in the Netherlands: Landscape History, v. 36, p. 5-34. 10.1080/01433768.2015.1108024

Van Beek, R., M. Gouw-Bouman, and J. Bos, 2015b. Mapping regional vegetation developments in Twente (the Netherlands) since the Late Glacial and evaluating contemporary settlement patterns: Netherlands Journal of Geosciences, v. 94, p. 229-255.

Van de Lageweg, W. I., W. M. van Dijk, D. Box, and M. G. Kleinhans, 2016. Archimetrics: a quantitative tool to predict three-dimensional meander belt sandbody heterogeneity: The Depositional Record, v. 2, p. 22-46. 10.1002/dep2.12

Van de Meene, E., J. Van der Staay, and L. H. Teoh, 1979. The Van der Staay suctioncorer: a simple apparatus for drilling in sand below groundwater table: Haarlem, Rijks Geologische Dienst.

Van den Berg, J. H., 1995. Prediction of alluvial channel pattern of perennial rivers: Geomorphology, v. 12, p. 259-279.

Van den Berg, M., and D. Beets, 1987. Saalian glacial deposits and morphology in The Netherlands: Tills and Glaciotectonics. Balkema, Rotterdam, p. 235-251.

Van Denderen, R. P., R. M. Schielen, A. Blom, S. J. Hulscher, and M. G. Kleinhans, 2018. Morphodynamic assessment of side channel systems using a simple one-dimensional bifurcation model and a comparison with aerial images: Earth surface processes and landforms, v. 43, p. 1169-1182.

Van der Hammen, T., 1971. The Upper Quaternary of the Dinkel Valley:(Twente, Eastern Overijssel, the Netherlands), Uitgevers-Maatschappij” Ernest van Aelst".

Van der Linden, J. A., 1973. Topographische en Militaire kaart van het Koningrijk der Nederlanden: Bussum, Fibula-Van Dischoeck, 75 p.

Van der Plicht, J., 2005. WinCal25. Groningen, the Netherlands: Center for Isotope Research, University of Groningen.

Van der Schaaf, S., 1999. Analysis of the hydrology of raised bogs in the Irish Midlands: a case study of Raheenmore Bog and Clara Bog, Wageningen Agricultural University, Wageningen.

Van Dijk, G., 1991. Holocene water level development in The Netherlands' river area; implications for sea-level reconstruction: Geologie en Mijnbouw, v. 70, p. 311-326.

Van Dijk, W., W. Lageweg, and M. Kleinhans, 2012. Experimental meandering river with chute cutoffs: Journal of Geophysical Research: Earth Surface (2003-2012), v. 117. doi:10.1029/2011JF002314 
Van Engelen, A. F., J. Buisman, and F. IJnsen, 2001, A millennium of weather, winds and water in the low countries, in P. D. Jones, ed., History and Climate: Norwell, Mass., Kluwer Acad., p. 101-124.

Van Heerd, R., and R. Van't Zand, 1999. Productspecificatie Actueel Hoogtebestand Nederland: Rijkswaterstaat Meetkundige Dienst, Delft.

Van Heteren, S., D. M. Fitzgerald, P. A. Mckinlay, and I. V. Buynevich, 1998. Radar facies of paraglacial barrier systems: coastal New England, USA: Sedimentology, v. 45, p. 181-200.

Van Iersel, W., M. Straatsma, H. Middelkoop, and E. Addink, 2018. Multitemporal classification of river floodplain vegetation using time series of UAV images: Remote Sensing, v. 10, p. 1144.

Van Leeuwaarden, W., 1982. Palynological and macropalaeobotanical studies in the development of the vegetation mosaic in Eastern Noord-Brabant (in the Netherlands) during Lateglacial and early Holocene times: Utrecht, Leeuwaarden.

Van Oorschot, M., M. Kleinhans, G. Geerling, and H. Middelkoop, 2016. Distinct patterns of interaction between vegetation and morphodynamics: Earth Surface Processes and Landforms, v. 41, p. 791-808.

Van Overmeeren, R. A., S. V. Sariowan, and J. C. Gehrels, 1997. Ground penetrating radar for determining volumetric soil water content; results of comparative measurements at two test sites: Journal of Hydrology, v. 197, p. 316-338. http://dx.doi.org/10.1016/ S0022-1694(96)03244-1

Vandenberghe, D., F. De Corte, J.-P. Buylaert, and J. Kučera, 2008. On the internal radioactivity in quartz: Radiation Measurements, v. 43, p. 771-775.

Vandenberghe, J., and S. Bohncke, 1985. The Weichselian Late Glacial in a small lowland valley (Mark River, Belgium and The Netherlands) [Le Weichselien tardiglaciaire dans une vallée des plaines basses (La rivière Mark, Belgique et Pays-Bas)]: Bulletin de l'Association française pour l'Étude du Quaternaire, v. 22, p. 167-175.

Vandenberghe, J., and J. Van Huissteden, 1988, Fluvio-aeolian interaction in a region of continuous permafrost: Proceedings of the V International Conference on Permafrost, Trondheim, Norway, p. 876-881.

Vandenberghe, J., C. Kasse, S. Bohncke, and S. Kozarski, 1994. Climate-related river activity at the Weichselian-Holocene transition: a comparative study of the Warta and Maas rivers: Terra nova, v. 6, p. 476-485.

Vandenberghe, J., 1995. Timescales, climate and river development: Quaternary Science Reviews, v. 14, p. 631-638. http://dx.doi.org/10.1016/0277-3791(95)00043-O

Vandenberghe, J., 2001. A typology of Pleistocene cold-based rivers: Quaternary International, v. 79, p. 111-121. http://dx.doi.org/10.1016/S1040-6182(00)00127-0

Vandenberghe, J., 2002. The relation between climate and river processes, landforms and deposits during the Quaternary: Quaternary International, v. 91, p. 17-23.

Vandenberghe, J., 2008. The fluvial cycle at cold-warm-cold transitions in lowland regions: A refinement of theory: Geomorphology, v. 98, p. 275-284. http://dx.doi.org/10.1016/j. geomorph.2006.12.030 
Vargas-Luna, A., A. Crosato, N. Anders, A. J. Hoitink, S. D. Keesstra, and W. S. Uijttewaal, 2018. Morphodynamic effects of riparian vegetation growth after stream restoration: Earth Surface Processes and Landforms, v. 43, p. 1591-1607.

Veldkamp, A., 1991. Quaternary river terrace formation in the Allier basin, France: a reconstruction based on sand bulk geochemistry and 3-D modelling, Wageningen University, Wageningen, $172 \mathrm{p}$.

Verbrugge, L., and R. Van den Born, 2018. The role of place attachment in public perceptions of a re-landscaping intervention in the river Waal (The Netherlands): Landscape and urban planning, v. 177 , p. 241-250.

Verdonschot, P. F., and M. Van den Hoorn, 2010. Using discharge dynamics characteristics to predict the effects of climate change on macroinvertebrates in lowland streams: Journal of the North American Benthological Society, v. 29, p. 1491-1509.

Verdonschot, P. F. M., and R. C. Nijboer, 2002. Towards a decision support system for stream restoration in the Netherlands: an overview of restoration projects and future needs: Hydrobiologia, v. 478, p. 131-148. 10.1023/a:1021026630384

Verdonschot, R. C., J. Kail, B. G. McKie, and P. F. Verdonschot, 2015. The role of benthic microhabitats in determining the effects of hydromorphological river restoration on macroinvertebrates: Hydrobiologia, p. 1-12.

Vermeulen, B., A. Hoitink, S. Berkum, and H. Hidayat, 2014. Sharp bends associated with deep scours in a tropical river: The river Mahakam (East Kalimantan, Indonesia): Journal of Geophysical Research: Earth Surface, v. 119, p. 1441-1454.

Vermeulen, B., A. Hoitink, and R. Labeur, 2015. Flow structure caused by a local crosssectional area increase and curvature in a sharp river bend: Journal of Geophysical Research: Earth Surface, v. 120, p. 1771-1783.

Vermeulen, B., A. Hoitink, G. Zolezzi, J. Abad, and R. Aalto, 2016. Multiscale structure of meanders: Geophysical Research Letters, v. 43, p. 3288-3297.

Viles, H., L. Naylor, N. Carter, and D. Chaput, 2008. Biogeomorphological disturbance regimes: progress in linking ecological and geomorphological systems: Earth Surface Processes and Landforms: The Journal of the British Geomorphological Research Group, v. 33, p. 1419-1435.

Vink, A. P. A., 1949. Bijdrage tot de kennis van loess en dekzanden: in het bijzonder van de zuidoostelijke Veluwe, Veenman.

Vos, P., J. Bazelmans, H. Weerts, and M. Van der Meulen, 2011. Atlas van Nederland in het Holoceen: Bakker, Amsterdam.

Wallinga, J., and J. Van der Staay, 1999. Sampling in water logged sands with a simple hand operated corer: Ancient TL, v. 17, p. 59-61.

Wallinga, J., 2002. Optically stimulated luminescence dating of fluvial deposits: a review: Boreas, v. 31, p. 303-322. 
Wallinga, J., F. Davids, and J. Dijkmans, 2007. Luminescence dating of Netherlands' sediments: Netherlands Journal of Geosciences-Geologie en Mijnbouw volume 86, No. 3 (October 2007).

Wallinga, J., N. Hobo, A. C. Cunningham, A. J. Versendaal, B. Makaske, and H. Middelkoop, 2010. Sedimentation rates on embanked floodplains determined through quartz optical dating: Quaternary Geochronology, v. 5, p. 170-175.

Walter, R. C., and D. J. Merritts, 2008. Natural Streams and the Legacy of Water-Powered Mills: Science, v. 319, p. 299-304. 10.1126/science.1151716

Wanner, H., J. Beer, J. Bütikofer, T. J. Crowley, U. Cubasch, J. Flückiger, H. Goosse, M. Grosjean, F. Joos, and J. O. Kaplan, 2008. Mid-to Late Holocene climate change: an overview: Quaternary Science Reviews, v. 27, p. 1791-1828.

Warburton, J., M. Danks, and D. Wishart, 2002. Stability of an upland gravel-bed stream, Swinhope Burn, Northern England: CATENA, v. 49, p. 309-329. https://doi. org/10.1016/S0341-8162(02)00046-2

Wastiaux, C., L. Halleux, R. Schumacker, M. Streel, and J.-M. Jacqmotte, 2000, Development of the Hautes-Fagnes peat bogs (Belgium): new perspectives using ground-penetrating radar: Suo, p. 115-120.

Waterschap De Dommel, 1941. Waterschap De Dommel, 1862-1941: Stukken betreffende de uitvoering van verbeteringswerken aan de rivier de Dommel, alsmede aan de kaden, duikers en kokers, Den Bosch, BHIC.

Watters, J. R., and E. H. Stanley, 2007. Stream channels in peatlands: The role of biological processes in controlling channel form: Geomorphology, v. 89, p. 97-110. http://dx.doi. org/10.1016/j.geomorph.2006.07.015

Wilde, S., and C. Tanzer, 1965. De Alluviale Gronden van de Maas, de Roer, en de Geul in Limburg (Alluvial Soils of the Rivers Maas, Roer, and Geul): Soil Science Society of America Journal, v. 29, p. iv-iv.

Williams, G. P., 1978. Bank-full discharge of rivers: Water resources research, v. 14, p. 1141-1154. Williams, G. P., 1986. River meanders and channel size: Journal of hydrology, v. 88, p. 147-164. Willis, B. J., 1989. Palaeochannel reconstructions from point bar deposits: a three-dimensional perspective: Sedimentology, v. 36, p. 757-766. 10.1111/j.1365-3091.1989.tb01744.x

Wintle, A. G., and A. S. Murray, 2006. A review of quartz optically stimulated luminescence characteristics and their relevance in single-aliquot regeneration dating protocols: Radiation Measurements, v. 41, p. 369-391.

Wohl, E., P. L. Angermeier, B. Bledsoe, G. M. Kondolf, L. MacDonnell, D. M. Merritt, M. A. Palmer, N. L. Poff, and D. Tarboton, 2005. River restoration: Water Resources Research, v. 41: W10301.

Wohl, E., and D. J. Merritts, 2007. What is a natural river?: Geography Compass, v. 1, p. 871-900.

Wohl, E., S. N. Lane, and A. C. Wilcox, 2015. The science and practice of river restoration: Water Resources Research, p. 5974-5997. 10.1002/2014wr016874 
Wohl, E., 2017. Bridging the gaps: An overview of wood across time and space in diverse rivers: Geomorphology, v. 279, p. 3-26.

Wolfert, H., and G. Maas, 2007. Downstream changes of meandering styles in the lower reaches of the River Vecht, the Netherlands: Netherlands Journal of Geosciences v. 86, p. 257-271.

Wolfert, H. P., G. Maas, and G. Dirkx, 1996. Het meandergedrag van de Overijsselse Vecht: historische morfodynamiek en kansrijkdom voor natuurontwikkeling, v. 408, DLOStaring Centrum.

Wolman, M. G., 1955. The natural channel of Brandywine creek, Pennsylvania, v. 271, US Government Printing Office.

Wolman, M. G., and J. P. Miller, 1960. Magnitude and frequency of forces in geomorphic processes: The Journal of Geology, v. 68, p. 54-74.

Woodyer, K., G. Taylor, and K. Crook, 1979. Depositional processes along a very lowgradient, suspended-load stream: the Barwon River, New South Wales: Sedimentary Geology, v. 22, p. 97-120.

Woolderink, H., C. Kasse, L. Grooteman, and R. Van Balen, 2019. Interplay between climatic, tectonic and anthropogenic forcing in the Lower Rhine Graben, the Roer River: Geomorphology.

Wynn, T. M., S. Mostaghimi, J. A. Burger, A. A. Harpold, M. B. Henderson, and L.-A. Henry, 2004. Variation in root density along stream banks: Journal of Environmental Quality, v. 33, p. 2030-2039.

Zanke, U., 2003. On the influence of turbulence on the initiation of sediment motion: International Journal of Sediment Research, v. 18, p. 17-31. 


\title{
Curriculum Vitae
}

\begin{abstract}
About the author
Jasper Candel was born at 29 November 1990 in Oosterhout, The Netherlands. He grew up with his older and twin brother in Dongen. Since he was young, Jasper was fascinated by nature and landscapes, therefore he studied the BSc Soil, Water, Atmosphere at Wageningen University $(2008$ - 2012). He spent half a year of his BSc in Sogndal, Norway at the Sogn og Fjordane University College where he followed the program "From Mountain

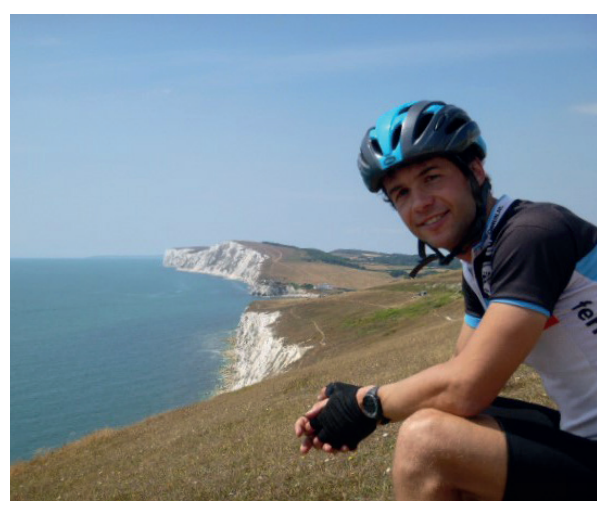
to Fjord". After his BSc, Jasper continued doing his MSc Earth and Environment at Wageningen University $(2012$ - 2014), with a specialization in Hydrology and Quantitative Water Management. Jasper spent half a year in Moscow, Idaho in the USA at the University of Idaho to do his MSc thesis research on palaeochannels recharging the local aquifers. After that he spent four months in Calgary, Canada, to study the effect of groundwater flooding for the company Deltares at the University of Calgary. During his studies, Jasper was an active member of the climbing association Ibex, and did many backcountry skiing, cross-country skiing, climbing, sailing, canoeing, cycling, hiking and other outdoor trips during his free time, which he is still doing these days. He has always been active in doing different kinds of sports and playing the piano. After his studies, Jasper started a PhD at the Soil Geography and Landscape group at Wageningen University (2014-2019), studying the channel pattern formation of low-energy rivers, which has resulted in this thesis. He will continue as a lecturer geomorphology and soil geography in this group.
\end{abstract}




\section{List of publications}

Candel, J. H. J., E. S. Brooks, R. Sánchez-Murillo, G. Grader, and R. Dijksma, 2016. Identifying groundwater recharge connections in the Moscow (USA) sub-basin using isotopic tracers and a soil moisture routing model: Hydrogeology Journal, v. 24, p. 17391751. 10.1007/s10040-016-1431-x

Candel, J. H. J., B. Makaske, J. E. A. Storms, and J. Wallinga, 2017. Oblique aggradation: a novel explanation for sinuosity of low-energy streams in peat-filled valley systems: Earth Surface Processes and Landforms, v. 42, p. 2679-2696. 10.1002/esp.4100

Candel, J. H. J., M. G. Kleinhans, B. Makaske, W. Z. Hoek, C. Quik, and J. Wallinga, 2018. Late Holocene channel pattern change from laterally stable to meandering - a palaeohydrological reconstruction: Earth Surf. Dynam., v. 6, p. 723-741. https://doi. org/10.5194/esurf-6-723-2018

Candel, J. H. J., B. Makaske, N. Kijm, M. Kleinhans, J. E. A. Storms, and J. Wallinga, in review. Self-constraining of low-energy meandering rivers; a novel explanation for tortuous planforms and low mobility: The Depositional Record.

Candel, J. H. J., M. G. Kleinhans, B. Makaske, and J. Wallinga, in review. Predicting river channel pattern based on stream power, bed material and bank strength: Progress in Physical Geography.

Cortes Arevalo, V. J., L. Verbrugge, A. Sools, M. Brugnach, R. Wolterink, R. P. Van Denderen, J. H. J. Candel, and S. J. M. H. Hulscher, in review. Storylines for practice: A visual storytelling approach to strengthen the science-practice interface: Sustainability Science.

Kleinhans, M. G., B. Vermeulen, J. L. Best, J. H. J. Candel, A. J. F. Hoitink, and B. Van Prooijen, in review. Cutting Corners: Causes, Mechanisms and Large-Scale Effects of Sharp Bends in Rivers, Estuaries and Deltas: Journal of Geophysical Research: Earth Surface.

Stoof, C. R., J. H. J. Candel, L. A. G. M. Van Der Wal, and G. Peek, 2019. Soil lacquer peel do-it-yourself: simply capturing beauty: Soil, v. 5, p. 159-175.

van Beek, R., J. H. J. Candel, C. Quik, J. A. A. Bos, M. T. I. J. Gouw-Bouman, B. Makaske, and G. J. Maas, 2019. The landscape setting of bog bodies: Interdisciplinary research into the site location of Yde Girl, The Netherlands: The Holocene, v. 29, p. 1206-1222. 


\section{PE\&RC Training and Education Statement}

With the training and education activities listed below the $\mathrm{PhD}$ candidate has complied with the requirements set by the C.T. de Wit Graduate School for Production Ecology and Resource Conservation (PE\&RC) which comprises of a minimum total of

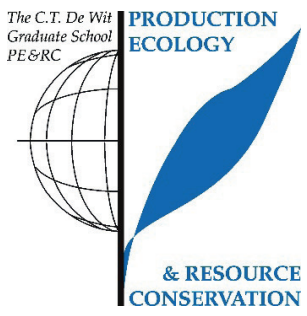
32 ECTS (= 22 weeks of activities)

Review of literature (4.5 ECTS)

- Morphodynamic functioning of regional river systems (2015)

Writing of project proposal (4.5 ECTS)

- Morphodynamic functioning of regional river systems (2015)

Post-graduate courses (3.9 ECTS)

- Workshop on modelling mixed-sediment river morphodynamics; Delft (2015)

- River restoration: fluvial geomorphic \& ecological tools; Malaucène (2015)

- Summerschool: restoring regulated streams linking theory and practice; Wageningen (2015)

- Workshop: inland drift sands: phases, causes and patterns; Utrecht (2016)

- Structure-from-motion techniques and applications for morphological monitoring; Trento (2017)

Invited review of (unpublished) journal manuscript (1 ECTS)

- Catena: small-scale palaeochannels in the Kleine Nete valley, NE Belgium: chronology and significance of the palaeohydrological archive (2018)

Deficiency, Refresh, Brush-up courses (3 ECTS)

- $\quad$ The $4^{\text {th }}$ dimension in Earth Sciences; Soil Geography and Landscape Group; Wageningen UR (2015)

Competence strengthening / skills courses (3.9 ECTS)

- Scientific writing; Wageningen UR (2016)

- Scientific artwork with Photoshop \& Adobe Illustrator; Wageningen UR (2016)

- Training in how to speak in front of the camera and working on a MOOC; Wageningen UR (2016)

- How to supervise MSc students; Wageningen UR (2016)

- Teknowlogy NWO-day: 1) what a personality, 2) energy and LED lighting in horticulture; TTW-NWO (2017) 
PE\&RC Annual meetings, seminars and the PE\&RC weekend (1.2 ECTS)

- PE\&RC First years weekend (2015)

- PhD Workshop Carousel (2016)

Discussion groups / local seminars / other scientific meetings (12.5 ECTS)

- Visitation of waterboards (2015)

- RiverCare excursion (2015)

- RiverCare day (2015-2019)

- Community of practice re-meandering meetings; oral presentations (20152019)

- User committee (2015-2019)

- Dissemination day for water managers; organisation and oral presentation; Utrecht (2016)

- NCR theme day; oral presentation: Utrecht (2016)

- NCR theme day; organization and oral presentation; Arriën (2016)

- Landscape dynamics discussion group meetings (2016-2017)

- Historische waterstaatkunde VU; oral presentation; Amsterdam (2017)

- Schuilingcongress; oral presentation; Schipborg (2017)

- Dissemination day for water managers; organisation and oral presentation; SintOedenrode (2019)

- Ecologica symposium; oral presentation; Eindhoven (2019)

International symposia, workshops and conferences (17.4 ECTS)

- NCR Conference; poster presentation; Nijmegen (2015)

- NCR Conference; organization and oral presentation; Wageningen (2017)

- ICFS Conference; oral and poster presentations; Calgary (2017)

- RCEM Conference; poster presentation; Padova (2017)

- NCR Conference; oral presentation; Delft (2018)

- FLAG Meeting; oral and poster presentation; Liège (2018)

- NCR Conference; poster presentation; Utrecht (2019)

- INQUA Conference; oral and poster presentation; Dublin (2019)

- NAC Conference; oral presentation; Utrecht (2019)

Lecturing / supervision of practicals / tutorials (40 ECTS)

- Landscape geography (2015-2019)

- Soils and landscapes of the Netherlands (2015-2019)

- Soil I practicals + excursion (2015-2019)

- BSc thesis supervision of 5 BSc students (2015-2019)

- Student-for-a-day days (2015-2019) 
- Environmental data collection and analysis (2016-2017)

- Open house day (2016-2018)

- Integration Course Soil, Water, Atmosphere (2017-2019)

- Habitat analysis (2018)

- Geologie, bodem en landschap van de Rijn-Maas delta (2019)

Supervision of 10 MSc students (27 ECTS)

- Eric Verhoeff: Identifying hydrologic recharge connections in the Moscow subbasin (USA), using stable isotopes as a tracer (2016)

- Claudia Labianca: Planform analysis of three contrasting streams in The Netherlands (2016)

- Ellen Moedt: Saalian-Holocene dynamics of the Drentsche Aa valley system (2017)

- Renathe Kamstra: A palaeogeographic reconstruction of a lowland stream in the southern Netherlands (2018)

- Niels Kijm: Late-Glacial and Holocene stream morphodynamics of the Dommel (2018)

- Erwin Steijsiger: Illuminating the history of fluvial sediments - finding a novel OSL method to describe fluvial phases (2018)

- Menno Verplak: River management and its morphological consequences Influence of river management on river morphology of the Overijsselse Vecht between AD 1750 - 1900 (2019)

- Erwin Steijsiger: Analysing a possible plug bar in the Junnerkoeland, Netherlands (2019)

- Tom Harkema: Channel pattern prediction of Dutch streams (2019)

- Gibran Leeflang: Boundary conditions of dispersed wetland systems in the Krycklan catchment in Northern Sweden (2020) 
This research is part of the research programme RiverCare, supported by the Netherlands Organization for Scientific Research (NWO) and the Dutch Foundation of Applied Water Research (STOWA), and is partly funded by the Ministry of Economic Affairs under grant number P12-14 (Perspective Programme).

Financial support from Wageningen University for printing this thesis is gratefully acknowledged.

Cover design: Meike Schipper

Printed \& Lay out by: Proefschriftmaken.nl || Uitgeverij BOXPress 